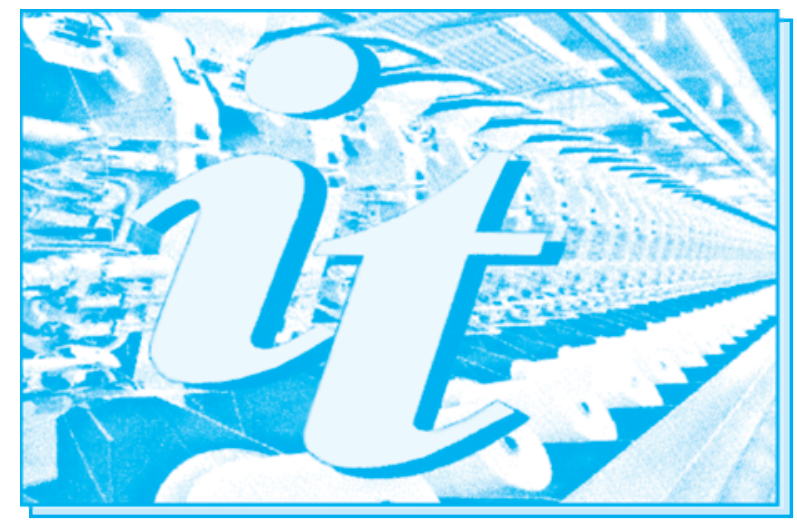

Revistă cotată ISI si inclusă în Master Journal List a Institutului pentru Știința Informării din Philadelphia - S.U.A., începând cu vol. 58 nr. $1 / 2007 /$

ISI rated magazine, included in the ISI Master Journal List of the Institute of Science Information, Philadelphia, USA, starting with vol. 58, no. 1/2007

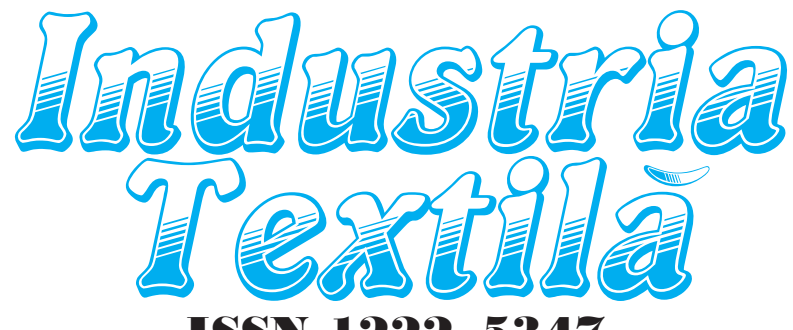

ISSN 1222-5347

$2 / 2017$

Editată în 6 nr./an, indexată și recenzată în:

Edited in 6 issues per year, indexed and abstracted in: Science Citation Index Expanded $\left(\mathrm{SciSearch}^{\circledR}\right)$, Materials Science Citation Index ${ }^{\circledR}$, Journal Citation Reports/Science Edition, World Textile Abstracts, Chemical Abstracts, VINITI, Scopus, Toga FIZ technik ProQuest Central

\section{CDLEFIUL DE REDACTIE:}

Dr. ing. CARMEN GHITULEASA CS I - DIRECTOR GENERAL

Institutul Naţional de Cercetare-Dezvoltare pentru Textile şi Pielărie - Bucureşti

\section{Dr. ing. EMILIA VISILEANU} CS I - EDITOR ŞEF

Institutul Naţional de Cercetare-Dezvoltare pentru Textile şi Pielărie - Bucureşti

Conf. univ. dr. ing. MARIANA URSACHE DECAN

Facultatea de Textile-Pielărie şi Management Industrial, Universitatea

Tehnică „Ghe. Asachi“ - laşi

\section{Prof. dr. GELU ONOSE} CSI

Universitatea de Medicină şi Farmacie "Carol Davila" - Bucureşti

Prof. dr. ing. ERHAN ÖNER Marmara University - Turcia

Prof. dr. MUGE YUKSELOGLU

Marmara University - Turcia

Prof. univ. dr. DOINA I. POPESCU Academia de Studii Economice - Bucureşti

Prof. univ. dr. ing. CARMEN LOGHIN Universitatea Tehnică „Ghe. Asachi“ - laşi

Prof. univ. dr. MARGARETA STELEA FLORESCU Academia de Studii Economice - Bucureşti

\section{Prof. ing. ARISTIDE DODU}

Membru de onoare al Academiei de Ştiinţe Tehnice din România

Prof. dr. ing. LUIS ALMEIDA University of Minho - Portugal

Prof. dr. LUCIAN CONSTANTIN HANGANU Universitatea Tehnică „Ghe. Asachi“" - Iaşi

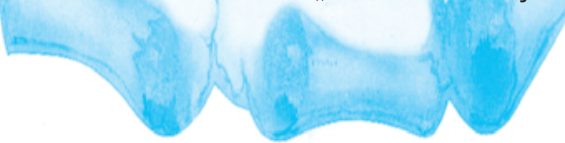

ADEEL ZULIFQAR, KHUBAB SHAKER, YASIR NAWAB, MUHAMMAD UMAIR, DANISH MAHMOOD BAITAB, MUHAMMAD MAQSOOD

Studiu asupra centurilor de siguranţă auto multistrat cu performanţă optimă 77-82

ANDREJA RUDOLF, LUCIE GÖRLICHOVÁ, JERNEJ KIRBIŠ, JASNA REPNIK, ANDREJ SALOBIR, IRMA SELIMOVIĆ, IGOR DRSTVENŠEK

Noile tehnologii în dezvoltarea îmbrăcămintei ergonomice pentru utilizatorii de scaune cu rotile în mediul virtual

GEORGETA POPESCU, SABINA OLARU, CLAUDIA NICULESCU

Tehnologii inovative de proiectare şi simulare a produselor vestimentare pentru copii utilizând date antropometrice obţinute prin scanare 3D standardizată

\section{B.YESIM BÜYÜKAKINCI}

Investigarea metodelor de vopsire a ţesăturilor din lână cu hibiscus şi eficienţa antibacteriană a acestora

\section{HÜSEYIN BENLI}

Studiu asupra capacităţii de vopsire a ţesăturii din lână cu extract din varză roşie (Brassica oleracea $L$. var.)

LAI-LI WANG, XUE-MEI DING, XIONG-YING WU

Evaluarea amprentei de apă pentru industria producătoare de textile din China

\section{ELEONORA GSELL, FRANK HEIMLICH, ANDREA EHRMANN,}

\section{MARCUS O. WEBER}

Dependența relaxării în stare uscată, umedă si la spălare de structura materialelor tricotate şi parametrii produsului

ESRA ZEYNEP YILDIZ, OKTAY PAMUK, SERKAN BOZ

Studiu asupra proprietăţilor de rezistenţă la tracţiune a cusăturii articolelor nețesute consolidate cu ultrasunete

EFTALEA CĂRPUS, CARMEN MIHAI, ANGELA DOROGAN, IULIA BIRLIBA Studiul corelaţiei caracteristicilor structurilor textile tricotate multifuncţionale

IOAN I. GÂF-DEAC, ALEXANDRA ENE, IOANA ANDREEA MARINESCU, MONICA CRISTINA VALECA, EMILIA VISILEANU

Protecţia drepturilor consumatorilor în marketingul computerizat din industria de textile și pielărie

GABRIEL BRĂTUCU, GHEORGHE EPURAN, DANIEL ADRIAN GÂRDAN, FLOAREA BUMBAS, ALEXANDRA ZAMFIRACHE

IULIANA PETRONEĹL GÂRDAN, MĂDĂLINA-ADINA (STĂNILĂ) OPRIȘ

Evoluţia industriei textile şi de confecţii din România: analiză

din perspectiva determinanţilor de importuri şi exporturi

SEBASTIAN ION CEPTUREANU, EDUARD GABRIELCEPTUREANU, EMILIA VISILEANU

Analiza comparativă a performanţelor organizaţionale ale întreprinderilor mici şi mijlocii din industria de confecţii

Recunoscută în România, în domeniul Științelor inginerești, de către Consiliul Național al Cercetării Științifice din Învățământul Superior (C.N.C.S.I.S.), în grupa A /

Aknowledged in Romania, in the engineering sciences domain, by the National Council of the Scientific Research from the Higher Education (CNCSIS), in group $A$ 


\section{Contents}

ADEEL ZULIFQAR, KHUBAB SHAKER, YASIR NAWAB, MUHAMMAD UMAIR, DANISH MAHMOOD BAITAB, MUHAMMAD MAQSOOD

ANDREJA RUDOLF, LUCIE GÖRLICHOVÁ, JERNEJ KIRBIŠ, JASNA REPNIK, ANDREJ SALOBIR, IRMA SELIMOVIĆ, IGOR DRSTVENŠEK

GEORGETA POPESCU, SABINA OLARU, CLAUDIA NICULESCU

B.YEŞIM BÜYÜKAKINCI

\section{HÜSEYIN BENLI}

LAI-LI WANG, XUE-MEI DING, XIONG-YING WU

ELEONORA GSELL, FRANK HEIMLICH, ANDREA EHRMANN, MARCUS O. WEBER

ESRA ZEYNEP YILDIZ, OKTAY PAMUK, SERKAN BOZ

EFTALEA CĂRPUS, CARMEN MIHAI, ANGELA DOROGAN, IULIA BIRLIBA

IOAN I. GÂF-DEAC, ALEXANDRA ENE, IOANA ANDREEA MARINESCU, MONICA CRISTINA VALECA,

EMILIA VISILEANU

GABRIEL BRĂTUCU, GHEORGHE EPURAN, DANIEL ADRIAN GÂRDAN,

FLOAREA BUMBAS

ALEXANDRA ZAMFIRACHE,

IULIANA PETRONELA GÂRDAN,

MĂDĂLINA-ADINA (STĂNILĂ) OPRIȘ

SEBASTIAN ION CEPTUREANU, EDUARD

GABRIELCEPTUREANU, EMILIA

VISILEANU

New technologies in the development of ergonomic garments for wheelchair users in a virtual environment

Innovative technologies for the design and simulation of children's clothing products using anthropometric data obtained by 3D standardized scanning

Investigation of dyeing methods on wool fabrics with hibiscus and its antibacteria efficiency

An investigation of dyeability of wool fabric with red cabbage (Brassica oleracea L. var.) extract

Water footprint assessment for Chinese textiles manufacturing sector

Dependence of dry, wet and washing relaxation on knitted structures and fabric parameters

An investigation on the seam tensile properties of ultrasonically bonded nonwoven fabrics

Correlation study of multifunctional knitted textile structures characteristics

The management of consumers' rights protection in computerised marketing in textiles and leather industry

The evolution of textile and clothing industry in Romania: an analysis from the perspective of imports and exports determinants

Comparative analysis of small and medium enterprises organizational performance in clothing industry

\section{Scientific reviewers for the papers published in this number:}

Prof. Blaga Mirela - University of Iaşi, România

Mehmat Karahan - Uludag University, Turkey

Prof. Francois Boussu - Ensait France

Senior Lecturer Dababrata Chowdhury - University of Suffolk United Kingdom, Suffolk, UK Prof. univ. dr. dr. HC Cătoiu Iacob - Academia de Studii Economice Bucureşti, România Conf. univ. dr. Chitu Ioana Bianca - Universitatea Transilvania din Braşov, România

Dr. Thomas Stegmaier - ITV-Dekendorf, Germany

Assist. prof. dr. Ozan Kayacan - Dokuz Eylul University Textile Engineering Department, Turky Prof. dr. Tomasz Blachowicz - Silesian University of Technology (Gliwice), Poland Dr. ing. Ene Alexandra - INCDTP, Bucureşti, România

\section{EDITORIAL STAFF}

Editor-in-chief: Dr. eng. Emilia Visileanu Graphic designer: Florin Prisecaru e-mail: industriatextila@ certex.ro

Journal edited in colaboration with Editura AGIR, 118 Calea Victoriei, sector 1, Bucharest, tel./fax: 021-316.89.92; 021-316.89.93; e-mail: editura@agir.ro,www.edituraagir.ro 


\title{
Investigation of multi-layered woven car seatbelts with optimum performance
}

\section{REZUMAT - ABSTRACT}

\section{Studiu asupra centurilor de siguranță auto multistrat cu performanță optimă}

\begin{abstract}
Această lucrare a avut ca scop studierea proprietăților mecanice ale centurii de siguranță auto țesute multistrat, prin varierea proiectării legăturii, desimii țesăturii și materialului. Trei straturi țesute au fost produse în trei legături diferite (diagonal, panama și combinata, denumită aici “combo"). Țesăturile au fost produse din poliester, poliamidă (nailon) sau prin utilizarea combinației între cele două. Centurile de siguranță cu legătură panama produse au fost capabile să suporte o sarcină mai mare înainte de a se rupe, în comparație cu legăturile diagonal și combo. S-a constatat efectul desimii reale a firului și al desimii țesăturii asupra rezistenței la rupere a centurii de siguranță. A fost propusă o centură de siguranță cu cost redus având o desime minimă a țesăturii și o rezistență optimă.
\end{abstract}

Cuvinte-cheie: centură de siguranță, rezistență la tensiune, produse multistrat

\section{Investigation of multi-layered woven car seatbelts with optimum performance}

This work was aimed to study the mechanical properties of multilayered woven automobile seatbelt by varying the weave design, fabric density and material. Three layered woven webs were produced in three different weaves (twill, matt and combination of plain and matt named here as "combo"). The webs were produced either in polyester, Polyamide (Nylon) or by using combination of both. The seatbelts produced in matt weave were able to bear more load before rupture as compared to twill and combo weaves. The effect of actual thread density and fabric areal densityon the breaking strength of seatbelt was found. Finally, a low cost seat belt having minimum fabric areal density and optimum strength was proposed.

Keywords: seatbelts, tensile strength, multilayer fabric

\section{INTRODUCTION}

Seatbelt is an energy ingesting product for automobiles, used by the passengers to keep them safe from injuries and casualties during a crash or an abrupt halt. By reducing the actual force of secondary impacts, seatbelts limit the risks of death as well as severe traumas in an accident. It also keeps the driver being ejected from the automobile in a collision or when the car rolls over [1]. Seatbelts are really easy to apply, efficient and cheap way of safeguard in case of accidents. These belts are usually jacquard woven webs (48 $\mathrm{mm}$ wide) [2]. The pattern of warp and weft and their response in case of loading or impact is responsible for wearer protection. Seatbelts are equipped with a load limiting retractor, a pre-tensioner and a D-ring which helps in reeling out of the belt from the retractor $[3,4]$. Seatbelt works on the principle of Newton's law of inertia: "A physical object at rest will remain resting and an object in motion will stay in motion with same speed and in same direction until acted upon by an external force". Whenever a car abruptly halts due to collision with a second object, the acceleration of car reduces instantly in a very short time, described by the law of inertia [5]. The second object provides force that alters the velocity and direction of car and it stops moving in the direction it was following, or may bounces back depending on the momentum of car. In this entire course, there is no force to stop the driver and passenger from moving forward. This situation is actually where the role of seatbelt starts. As the individual keep on moving in the same way, the seatbelt grabs him protecting from moving in to the air. In the alternative case, when the passenger did not put on seatbelt a force will act upon them so as to slow their speed. Such force will come through the dashboard or wind shield because the person collides into it leading to a great deal of injury to the head and spinal cord that can be fatal [6]. While it is important that people of all ages wear seat belts, it is especially important for teenagers because their crash rate is much higher than other age groups [1]. According to World Health Organization (WHO) report, 1.2 million individuals die each year through road accidents, all over the globe. The seatbelts are likely to lessen the danger regarding severe injuries in crashes by $60-70 \%$ plus the risk for deaths by about $45 \%$. Seatbelts minimize the severity of injury caused by the road traffic collisions by keeping the wearers in their position and restricting them from hitting the frontal vehicle components like dash board or windshield. Seatbelts also help in spreading the kinetic energy of the body that is the outcome of sudden deceleration. This energy is fragmented through the body skeleton [7]. In early times the Lap belts were used which hold the body at two points only (figure 1). 


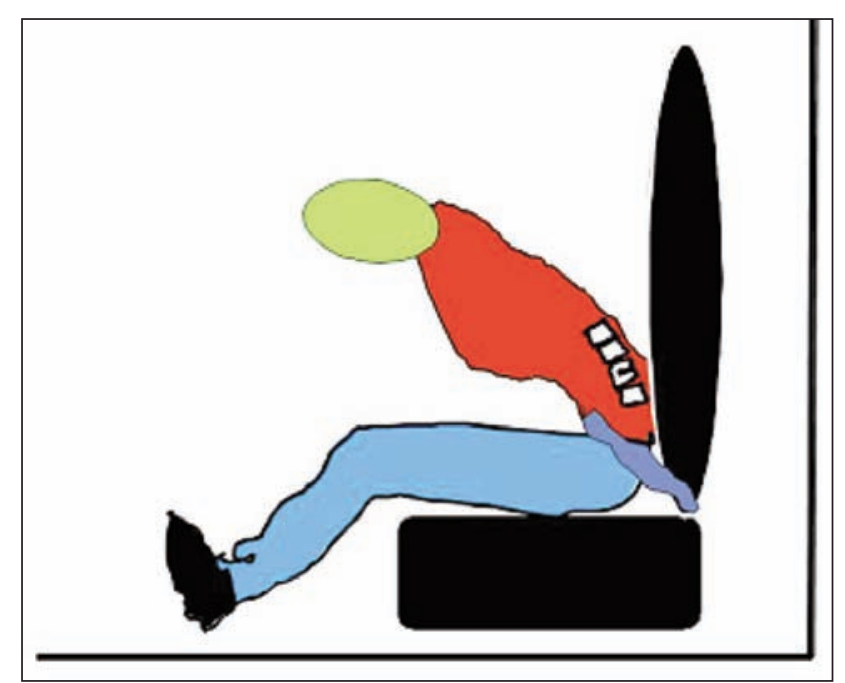

Fig. 1. The movement of body in case of Lap Belt

The belt acts as a fulcrum about which the body pivots causing major force directed toward the lumbar spine [8-10]. They do not provide protection to head and chest as the upper part of body can move forward to hit the windscreen or the steering wheel, the abdominal viscera can also be injured. Shoulder restraints were then introduced [11].

Filament yarns are used commonly to make the seatbelt webbing. In early times, cotton, flax and wool were used for seat belt webbing. Modern seatbelt webbing consists of synthetic fibers like Nylon, Polypropylene, Polyester, Dyneema ${ }^{\circledR}$ as well as Kevlar. Two synthetic materials are mostly use, Nylon and polyester. Nylon is use to make the Lap belt and Polyester is used to manufacture the diagonal range. In the late 1960's and early 1970's a research on narrow fabric was conducted to ascertain the preferred fiber. Static and dynamic loads are applied on polyester and nylon seatbelts in testing and results were related with the structure and shape of the seatbelt as well as the total deceleration rate of vehicle. The polyester was considered superior due to high stiffness and low extensibility [12]. Seatbelt structures can be single layer or double layer and manufactured on needle looms. Plain, Twill (2/2 Twill, Herringbone) and satin are normally used in construction of seatbelt. Plain weave was used in early days with the combination of cotton, wool or flax as material. The $2 / 2$ herringbone twill is mostly used now a day as it provides maximum interlacement of warp and weft, giving a compact structure [13]. To establish the mechanical performance of the webbing the testing is carried out following British Standard Institution (BSI) and the Society of Automotive Engineers (SAE) for different properties like; elongation at break, breaking strength, thickness and width, abrasion resistance at conditions which are most likely to resemble with the real life scenario. Buckles and fittings, effect of different environmental conditions and temperatures, rubbing fastness and microbial resistance can also be tested [14].
The strength of a seatbelt is limited by the strength of its weakest parts. The weakest parts of the seatbelt are the joints between the webbing and other components, or those components themselves. A seatbelt is required to perform satisfactorily under conditions of very high strain rate. The strength of seatbelt webbing is usually determined by means of conventional slow strain rate (so called static tension testing). In addition AS E35 requires that the static strength of webbing connections be evaluated as part of a program of tests required for the purpose of examining the detrimental effects of sunlight and heat on the strength of webbing, thread and webbing connections. AS 1753 is implemented to test the tensile strength of webbing. Direct determination of strength of webbing is a difficult matter chiefly because of the problem of gripping the webbing without including fracture of the test specimen in the grips. For a valid reading of strength, the fracture must occur outside the middle third of the between-grip length.

Safety belts to keep the luggage in position known as trunk belts have also been developed. One of the modern inventions is the inflatable seat belts which is actually a combination of seat belt and air bag. It provides $450 \%$ more surface area than conventional seat belt. Theses belts are stitched weekly in a folded envelope that will open up like a burst on inflation. By using such belts kinetic energy of passenger is distributed over a larger area, therefore load experienced by a passenger is small and passenger protected very effectively [15]. The performance of the vehicle seat belt can be enhanced by using belt positioning boosters; such boosters change the position of the belt with respect to the position of the wearer [16]. The airbag, jointly with the seat belts, must assure passengers safety in the case of a car accident. The combination of seatbelt use and frontal air bags is highly effective in frontal impacts, reducing front-seat occupants' fatality risk by an average of $61 \%$ compared to an unbelted occupant in a vehicle without air bags [17]. In the early 1970's the seatbelts were developed with the combination of air bags and legislated in 1993. Death and injury rates were greatly reduced by this combination [18]. There are 1.7 times more chances of cervical spine fracture, and 6.7 times more of spinal cord injury when using air bags or seatbelts alone. Also in some cases maxillofacial and ocular injuries were reported as a complication of airbags when seatbelts are not used [19, 20]. The development of modern seats with integrated seat belts also proved best performance during frontal impacts [21].

Despite the detailed research on seat belts and their significance, there is still a gap in the area of web weaving patterns. Some work is required that focus directly on different kind of weaving patterns to achieve optimum properties in the web for seat belts. For instance, mostly plain, twill and satin weaves are employed to the woven webs for seatbelts, and playing with the intersections of warp and weft in relation to the web properties is not deeply studied. The aim of this study is to manufacture the multilayer woven webs in different weave designs to get the maximum 
strength, keeping the areal density and thread density to minimum.

\section{MATERIALS}

Three different weave designs i.e. 2/2 matt, 2/2 twill and $2 / 2$ matt-plain combination (termed as combined weave) were used to produce the three layered woven structures. The different weave designs were used because interlacement pattern directly affects the properties of the resulting fabric structure. The cross sectional view of these weaves is given in figure 2 .

The materials used for the production of seatbelts were multifilament polyamide and polyester yarn. Two different linear densities were used for both the materials; i.e. 130 tex along warp and 65 tex along the weft direction. The list of samples produced for the study is given in table 1 .

These structures were woven on the narrow needle weaving machine. It is specifically designed to produce the ribbons, tapes and the webbings less than $50 \mathrm{~mm}$ in width. The weft insertion is continuous, and a needle is used to insert the weft yarn across the shed. Due to the production of a small fabric width, the beam is not prepared rather warp yarns are directly supplied from the creel.

These multilayer woven structures were treated with Phobotex CPNH finish from HUNTSMAN ${ }^{\circledR}$ to impart

protection against stains. It is a fluorocarbon finish having excellent repellency against oil, water and stains. A solution of the finish was prepared in water using concentration of $40 \mathrm{~g} / \mathrm{l}$, and a few drops of acetic acid were added to maintain $\mathrm{pH}$ at 5 . The multilayer structures were dipped in the solution, squeezed at a nip pressure of 2 bars to remove excess of liquor and dried at $110^{\circ} \mathrm{C}$ for 3 minutes.

As discussed in the previous section, the tensile properties of the woven seatbelt structure were tested according to the standard AS 1753-90. According to this standard, the seatbelts are classified and designated into classes based on the width and breaking strength as given below:

\section{Seatbelt width}

$$
\begin{aligned}
& \geq 19 \mathrm{~mm} \text { and }<23 \mathrm{~mm} \\
& \geq 23 \mathrm{~mm} \text { and }<34 \mathrm{~mm} \\
& \geq 34 \mathrm{~mm} \text { and }<46 \mathrm{~mm} \\
& \geq 46 \mathrm{~mm} \text { and }<76 \mathrm{~mm}
\end{aligned}
$$

Seatbelts breaking force

$$
\begin{aligned}
& \geq 3 \mathrm{kN} \\
& \geq 7 \mathrm{kN} \\
& \geq 11 \mathrm{kN} \\
& \geq 13 \mathrm{kN} \\
& \geq 16 \mathrm{kN} \\
& \geq 22 \mathrm{kN}
\end{aligned}
$$

designator $A$ designator $B$ designator $\mathrm{C}$ designator $D$ designator 3 designator 7 designator 11 designator 13 designator 16 designator 22

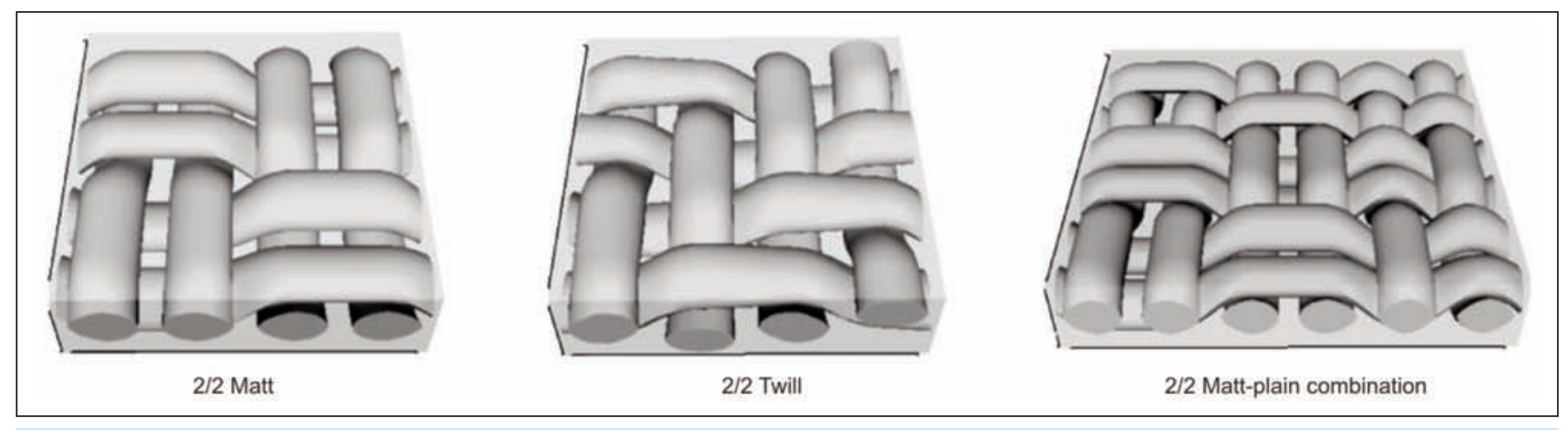

Fig. 2. Schematic view of Matt, Twill and Combined weaves

\begin{tabular}{|c|c|c|c|c|}
\hline \multicolumn{5}{|c|}{ Table 1} \\
\hline S. \# & Reference ID & Warp & Weft & Weave Design \\
\hline 1 & PPT & Polyester & Polyester & $2 / 2$ twill \\
\hline 2 & PNT & Polyester & Polyamide (Nylon) & $2 / 2$ twill \\
\hline 3 & PPC & Polyester & Polyester & $2 / 2$ Matt Plain combo \\
\hline 4 & PNC & Polyester & Polyamide (Nylon) & $2 / 2$ Matt Plain combo \\
\hline 5 & PPM & Polyester & Polyester & $2 / 2$ Matt \\
\hline 6 & PNM & Polyester & Polyamide (Nylon) & $2 / 2$ Matt \\
\hline 7 & NNT & Polyamide (Nylon) & Polyamide (Nylon) & $2 / 2 /$ twill \\
\hline 8 & NPT & Polyamide (Nylon) & Polyester & $2 / 2$ twill \\
\hline 9 & NNC & Polyamide (Nylon) & Polyamide (Nylon) & $2 / 2$ Matt Plain combo \\
\hline 10 & NPC & Polyamide (Nylon) & Polyester & $2 / 2$ Matt Plain combo \\
\hline 11 & NNM & Polyamide (Nylon) & Polyamide (Nylon) & $2 / 2$ Matt \\
\hline 12 & NPM & Polyamide (Nylon) & Polyester & $2 / 2$ Matt \\
\hline
\end{tabular}

Where, $\mathrm{N}$ represents Polyamide (Nylon), $\mathrm{P}$ for polyester, $\mathrm{T}$ for $2 / 2$ twill, $\mathrm{M}$ for $2 / 2$ matt and $\mathrm{C}$ for 2/2matt-plain combo. 


\section{RESULTS AND DISCUSSIONS}

The tensile properties of all the samples including tensile strength and elongation were performed at an extension rate of $100 \mathrm{~mm} / \mathrm{min}$, with gauge length of $60 \mathrm{~mm}$ on the Universal Tensile Tester. Five samples were tested along warp direction for each woven structure. The average values of breaking strength with standard deviation are shown in figure 3 .

The width of all the seatbelt structures developed for this study was $40 \mathrm{~mm}$. If we have a look at the breaking force of best four samples, it is more than $3 \mathrm{kN}$, and therefore these seatbelts can be designated as class 3C.

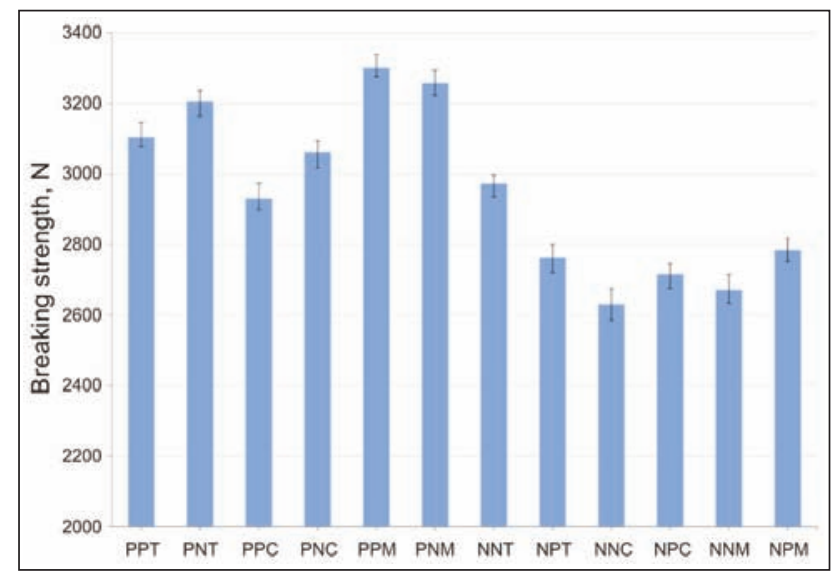

Fig. 3. Breaking strength of seatbelts for the fabricated samples

Firstly, it may be noted that woven structures constructed with polyester in warp direction have shown more breaking strength as compared to the structures constructed with polyamide in the warp. The main reason is because polyester yarns have a higher value of tenacity $(7 \mathrm{~g} / \mathrm{den})$, as compared to the polyamide yarns $(5.5 \mathrm{~g} / \mathrm{den})$. Therefore, the difference in the breaking strength of structures is due to the properties of material used. It may be concluded that the material has a significant impact on the

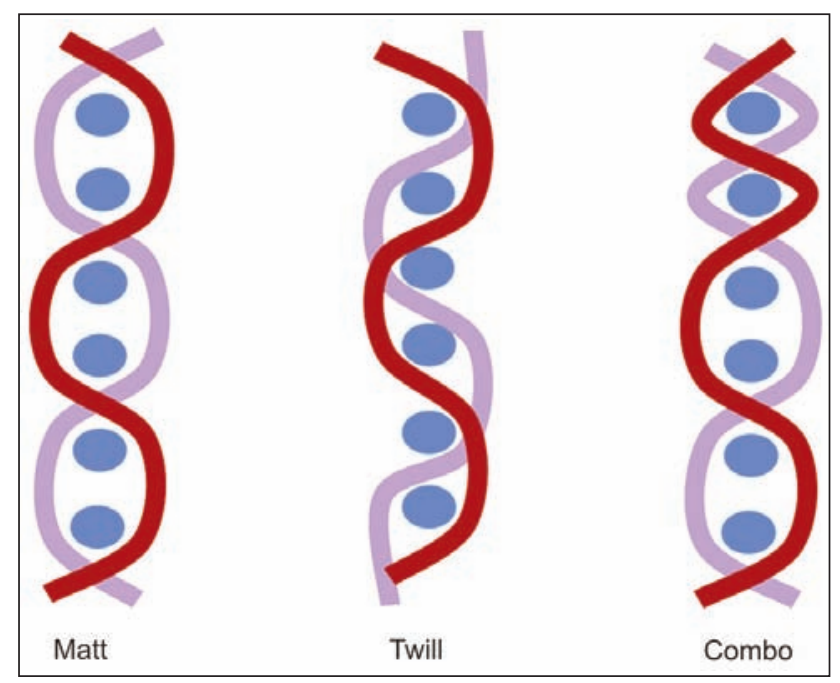

Fig. 4. Cross sectional views of weave designs used for seatbelts breaking strength of the seatbelt. There is also a variation in breaking strength among the structures produced with same material as warp. This difference has aroused from the difference in the interlacement pattern of each structure.

It is evident from the figure 3 that the breaking strength of the structures produced in the matt weave is higher as compared to the other weaves. It can be best understood if we have a look at the cross sectional view of the weave structures (figure 4). In case of matt weave, the yarns are mostly in a straight position, as compared to the twill and plain-matt combination weaves, which have more number of interlacements and crimp. Also the yarns in matt weave are in the form of group. When subjected to the axial loading, these straight segments will bear the load and the majority of filaments will contribute to the strength of the woven structure. In case of twill and plain-matt combination weaves, the crimped portion of yarn will not contribute to the load bearing. Ultimate result will be a low breaking strength value of these structures. The effect is further explained in figure 6 .

The mean value of breaking elongation along with standard deviation of woven seatbelt structures are shown in the figure 5 . The results show a remarkable difference in the elongation $\%$ of polyester warp and polyamide warp seatbelt structures. It is also intrinsic property of the material, i.e. the polyester yarn has a less elongation of $20 \%$, while polyamide yarns have higher elongation upto $55 \%$. The weave design has also effect on the elongation \% of the woven structure. The matt weave has les number of intersections and low crimp, therefore the elongation $\%$ of matt woven structures is low. On the other hand, the plainmatt combination weave has more number of interlacements and higher crimp giving high value of elongation\%.

The combined effect of weave design and material on the breaking strength of woven seatbelt structures is shown in figure 6 . It can be seen that the matt weave is stronger than plain-matt combination and twill weaves because the yarns are in pair and are orderly arranged.

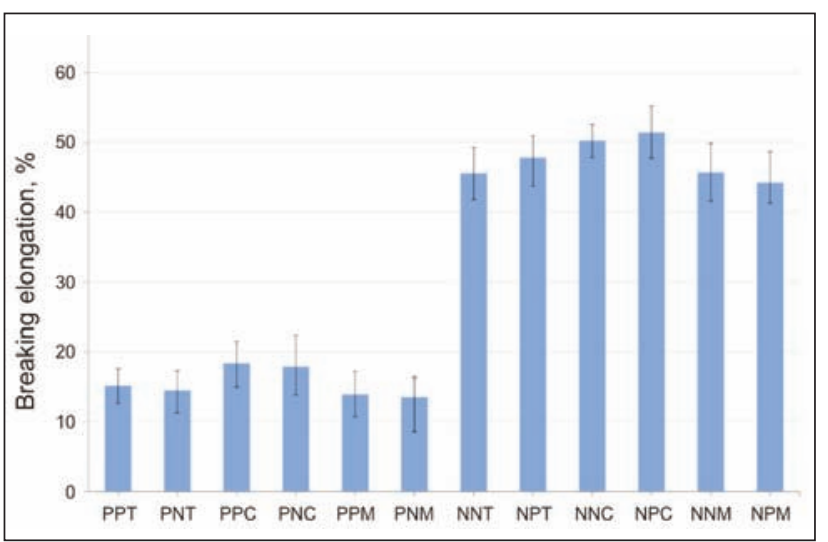

Fig. 5. Elongation of the seatbelt samples 


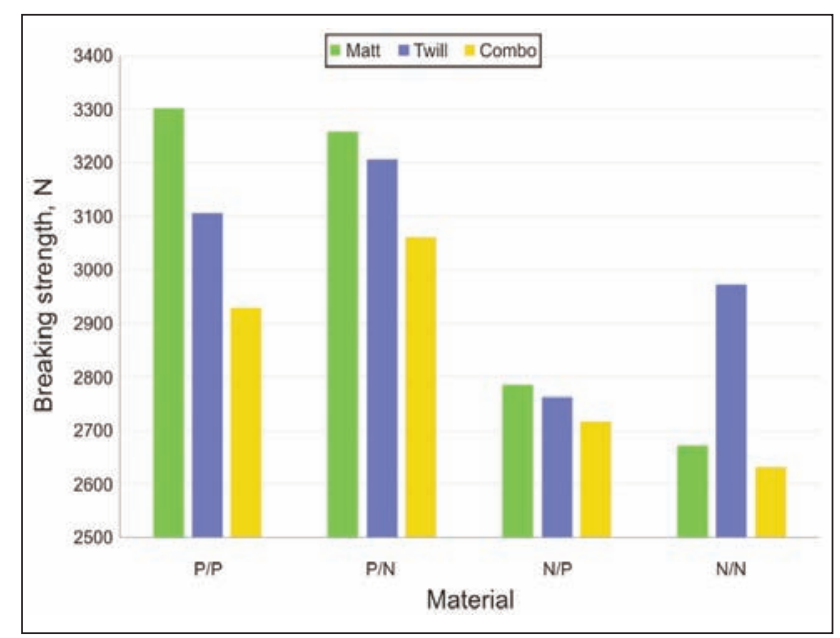

Fig. 6. Breaking strength of seatbelts with different materials: $\mathrm{P} / \mathrm{P}=$ warp \& weft polyester, $\mathrm{P} / \mathrm{N}=$ warp polyester $\&$ weft Polyamide (Nylon), N/P = warp Polyamide (Nylon) $\&$ weft polyester, N/N = warp and weft Polyamide (Nylon)

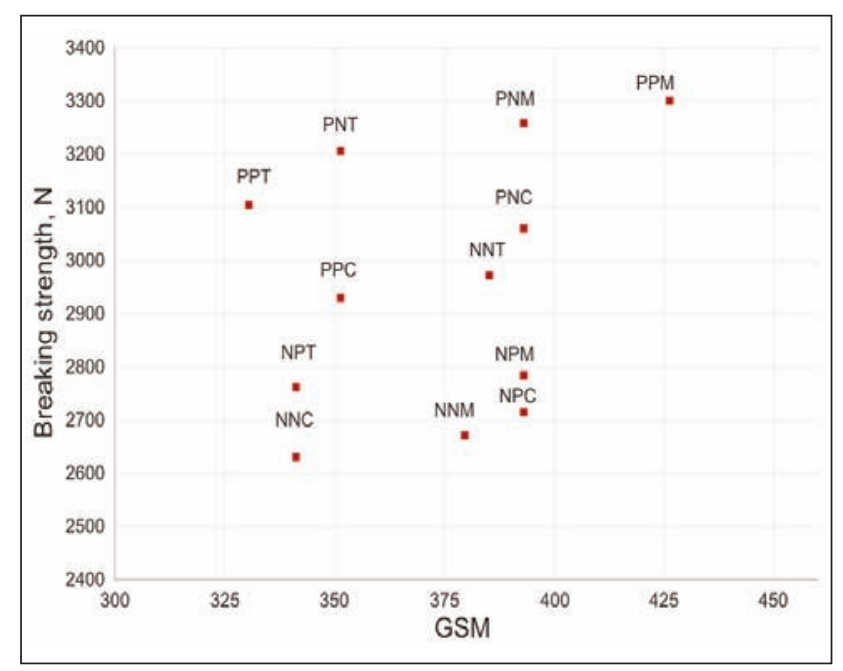

Fig. 7. Breaking load versus fabric areal density (GSM)

The effect is the same for all the materials (polyester and polyamide), either used along warp or weft with a few exception only. Although float length is same for twill and matt weave but in matt weave there are always two yarns present to bear the strength. As the structure is multilayer, the warp yarns are also used as stitching yarns to hold the layers together. The GSM wise comparison of breaking load is shown in figure 7 . The general trend in the results is that structures produced with low GSM have less strength while structures produced in high GSM have more strength.

For example NNC has low GSM and low breaking strength as compared to NNM. The trend is the same if we look at the results of seatbelt structures produced in the same material, i.e. the structures with polyamide as warp yarn have less breaking strength as compared to the samples with polyester yarns

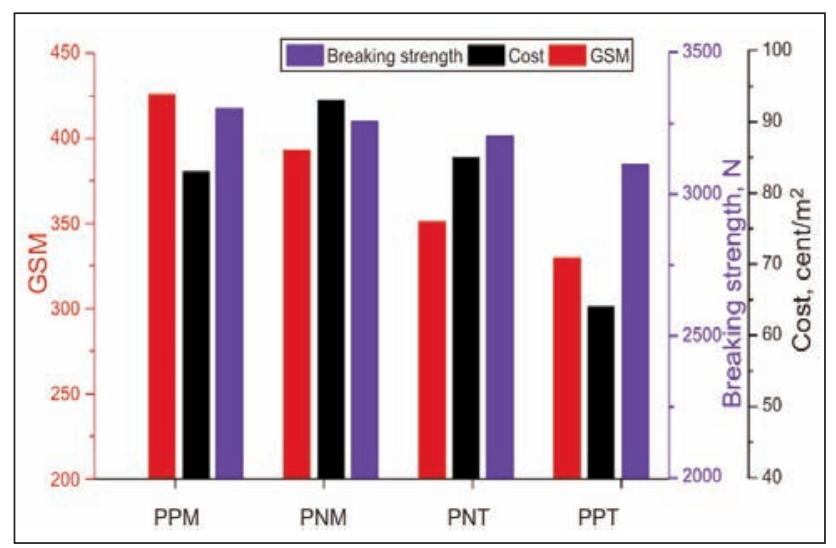

Fig. 8. Breaking strength, GSM and cost comparison of best four structures

because Polyamide (Nylon) has less strength than the polyester yarn as discussed earlier.

From the figure 7 , it can be observed that the highest value of breaking strength was achieved with PPM, PNM, PPT and PNT. Taking into account the breaking strength, cost and the GSM of these structures, one best structure is to be decided. A comparison graph of these four structures was plotted (figure 8). The objective was to develop a low cost and light weight seatbelt with optimum mechanical properties. It can be observed that the seatbelt structure PNT has relatively low GSM with optimum mechanical properties. Also the cost of this structure is comparable to the PPT (having high GSM and best mechanical properties).

\section{CONCLUSION}

On the base results, it can be concluded that the yarn material used in the construction of seatbelt structure has direct impact on its properties. The polyester used as warp for seatbelts gives more breaking strength as compared to polyamide (Nylon). This is due to the inherent difference in the tenacity of both the fibers. Also the elongation $\%$ of these structures vary, because the polyamide (Nylon) has more elongation than polyester yarn, so it takes more time to rupture and more strain is produced in it. The other factor contributing to the properties of seatbelts is the weave design. Structures produced in matt weave can bear more load before rupture as compared to twill and plain-matt combination weaves. The third important factor affecting the breaking strength of seatbelt is the areal density of fabric. Higher the areal density of seatbelt, higher is its breaking strength. All these properties were found optimum for the structure PNT, along with its cost.

\section{ACKNOWLEDGEMENTS}

The authors would like to express their appreciation for National Textile University R\&D Funding body for their support. 


\section{BIBLIOGRAPHY}

[1] I. A. Goldzweig, R. S. Levine, D. Schlundt, R. Bradley, G. D. Jones, R. J. Zoorob and O. J. Ekundayo, Improving seat belt use among teen drivers: Findings from a service-learning approach, In: Accident Analysis \& Prevention, vol. 59, pp. 71-75, 2013.

[2] D. Carr, G. Starling, T. de Wilton and I. Horsfall, Tensile properties of military chin-strap webbing, In: Text. Res. J., vol. 84, pp. 655-661, 2014.

[3] D. Dubois, H. Zellmer and E. Markiewicz, Experimental and numerical analysis of seat belt bunching phenomenon, In: Int. J. Impact Eng., vol. 36, pp. 763-774, 2009.

[4] D. Dubois, P. Silverthorne and E. Markiewicz, Assessment of seat belt webbing bunching phenomena, In: Int. J. Impact Eng., vol. 38, pp. 339-357, 2011.

[5] R. A. Freedman, Sears and Zemansky's University Physics. Pearson education, 2008.

[6] K. Singha, Strategies for in automobile: strategies for using automotive textiles-manufacturing techniques and applications, In: Journal of Safety Engineering, vol. 1, pp. 7-16, 2012.

[7] S. Bendak, Seat belt utilization in Saudi Arabia and its impact on road accident injuries, In: Accident Analysis \& Prevention, vol. 37, pp. 367-371, 2005.

[8] A. K. Abbas, A. F. Hefny and F. M. Abu-Zidan, Seatbelts and road traffic collision injuries, In: World J Emerg Surg, vol. 6, pp. 18, 2011.

[9] F. M. Abu-Zidan, A. K. Abbas, A. F. Hefny, H. O. Eid and M. Grivna, Effects of seat belt usage on injury pattern and outcome of vehicle occupants after road traffic collisions: prospective study, In: World J. Surg., vol. 36, pp. 255-259, 2012.

[10] E. Greenbaum, L. Harris and W. X. Halloran, Flexion fracture of the lumbar spine due to lap-type seat belts, In: Calif. Med., vol. 113, pp. 74-76, Sep, 1970.

[11] N. J. Hodson-Walker, The value of safety belts: a review, In: Can. Med. Assoc. J., vol. 102, pp. 391-393, Feb 28, 1970.

[12] J. Mclntyre, Synthetic fibres: nylon, polyester, acrylic, polyolefin; Woodhead Publ, In: Ltd., Cambridge, England, pp. 219-222, 2005.

[13] A. Ashland, Automotive composites on show, 2009.

[14] K. Lin, S. Chowdhury and Z. Wang, Catalytic gasification of automotive shredder residues with hydrogen generation, In: J. Power Sources, vol. 195, pp. 6016-6023, 2010.

[15] G. Nilson, Effects of seat and seat-belt design on car occupant response in frontal and rear impacts, 1994.

[16] M. P. Reed, S. M. Ebert, C. P. Sherwood, K. D. Klinich and M. A. Manary, Evaluation of the static belt fit provided by belt-positioning booster seats, In: Accident Analysis \& Prevention, vol. 41, pp. 598-607, 2009.

[17] R. W. Rudd, J. Bean, C. Cuentas, C. J. Kahane, M. Mynatt and C. Wiacek, A study of the factors affecting fatalities of air bag and belt-restrained occupants in frontal crashes, In: Proceedings of the 21st Enhanced Safety of Vehicles Conference, Paper, 2009.

[18] S. J. Monkhouse and M. D. Kelly, In: Journal of Medical Case Reports, vol. 2, pp. 1-3, 2008.

[19] N. F. Hall, A. M. Denning, A. R. Elkington and P. J. Cooper, The eye and the seatbelt in Wessex, In: Br. J. Ophthalmol., vol. 69, pp. 317-319, May, 1985.

[20] J. Mouzakes, P. J. Koltai, S. Kuhar, D. S. Bernstein, P. Wing and E. Salsberg, The impact of airbags and seat belts on the incidence and severity of maxillofacial injuries in automobile accidents in New York State, In: Archives of Otolaryngology-Head \& Neck Surgery, vol. 127, pp. 1189-1193, 2001.

[21] R. Preston, G. Amato, M. Lyons and C. Simms, A static test method to assess swivel seat strength in frontal impact, In: International Journal of Crashworthiness, vol. 19, pp. 469-483, 2014.

\section{Authors:}

\section{ADEEL ZULIFQAR \\ KHUBAB SHAKER \\ YASIR NAWAB \\ MUHAMMAD UMAIR \\ DANISH MAHMOOD BAITAB \\ MUHAMMAD MAQSOOD}

National Textile University

Faculty of Engineering and Technology

Department of Weaving

Sheikhupura road, 37610, Faisalabad, Pakistan

e-mail: shaker.khubab@gmail.com, yasir.nawab@yahoo.com, umair.ntu@gmail.com, danishbaitab@hotmail.com, engr.maqsood@hotmail.com

\section{Corresponding author:}

ADEEL ZULIFQAR

textilian2005@yahoo.com 


\section{New technologies in the development of ergonomic garments for wheelchair users in a virtual environment}

DOI: 10.35530/IT.068.02.1371

\section{REZUMAT - ABSTRACT}

\section{Noile tehnologii în dezvoltarea îmbrăcămintei ergonomice pentru utilizatorii de scaune cu rotile în mediul virtual}

În ultimii ani, prototiparea virtuală s-a dezvoltat în procesul de realizare a îmbrăcămintei de-a gata și a celei personalizate, prin utilizarea scanărilor $3 D$ ale corpului persoanelor complet mobile (FMP). Scopul acestui studiu a fost de a evalua caracterul adecvat al tehnologiilor de scanare $3 D$ și de simulare virtuală în procesul de dezvoltare a îmbrăcămintei ergonomice pentru persoanele imobilizate în scaun cu rotile (IMP). Un prototip de scaun a fost dezvoltat pentru scanarea persoanelor imobilizate în scaun cu rotile. O analiză comparativă a măsurătorilor virtuale (VM) și a măsurătorilor manuale (MM) ale corpurilor scanate $3 D$ a fost realizată pentru persoanele complet mobile şi pentru persoanele imobilizate în scaun cu rotile pentru a descoperi dacă echilibrul redus al corpului persoanelor imobilizate în scaun cu rotile afectează acuratețea modelelor 3D ale corpului. İmbrăcămintea ergonomică a fost dezvoltată folosind prototiparea virtuală, confecționată și testată de persoanele imobilizate în scaun cu rotile. Rezultatele statistice au indicat faptul că mobilitatea unei persoane nu afectează acuratețea VM. Tehnologia de simulare virtuală a arătat că îmbrăcămintea ergonomică poate fi dezvoltată fără solicitarea inutilă a testelor obişnuite de probare a îmbrăcămintei reale în cazul persoanelor imobilizate în scaun cu rotile.

Cuvinte-cheie: utilizatori în scaun cu rotile, îmbrăcăminte ergonomică, scanare 3D, dimensiuni ale corpului, simulare virtuală

\section{New technologies in the development of ergonomic garments for wheelchair users in a virtual environment}

In recent years, virtual prototyping has increased in the ready-and custom-made garments' development process using the standing $3 D$ body scans of Fully Mobile People (FMP). The purpose of this study was to evaluate the suitability of the $3 D$ scanning and virtual simulation technologies in the ergonomic garments' development process for Immobile People (IMP) using a wheelchair. A chair prototype was developed for the scanning of IMP. A comparative analysis of the scanned 3D bodies' Virtual Measurements (VM) and Manual Measurements (MM) was performed for FMP and IMP to find if the poor body balance of the IMP affects the accuracy of $3 D$ body models. The ergonomic garments were developed using virtual prototyping, sewn and tested by IMP. The statistical results indicated that the mobility of a person doesn't affect the accuracy of the VM. The virtual simulation technology showed that ergonomic garments can be developed without unnecessary burdening of the IMP with the usual fitting trials of the real garments.

Keywords: wheelchair users, ergonomic garments, 3D scanning, body dimensions, virtual simulation

\section{INTRODUCTION}

People with physical disabilities, either due to chronic sickness, injury, ageing or some other reasons, have to spend a large part of time in a sitting posture or confined to wheelchairs [1]. Data of the World Health Organisation show that over 1 billion people globally experience disability and, among them, 70 million people are wheelchair dependent [2]. In a study by Chang it was shown that there are evident differences between disabled and non-disabled people [3]. For the disabled it is necessary to maintain the same psychological status and social identity as in the case of healthy people. It is well-known that garments play an important role as a social identity factor throughout human life. In the study regarding the disabled consumers, it was found that the garment design and function, self-expression and social identity are the basic requests for garment selection and usages among disabled females [4]. In addition, difficulties of the disabled user in finding suitable garments and the importance of the garments' appearance due to self-esteem and life satisfaction were identified in works by $[3,5,6]$. The body features (shape, size and mobility) of the wheelchair users frequently exhibit one or more of the following three characteristics: (a) Loss of balance due to spine injury and changes in the body shape (left-right asymmetry and irregular body shape), (b) Poor blood circulation, lower skin temperature and physical inactivity of the damaged body parts tend to weaken the muscle functions and provoke muscular atrophy of the limbs, (c) Using a wheelchair leads to evident expansion of relevant muscle groups of the upper limbs [3]. Therefore, there is a great need regarding the custom-adapted ergonomic garments for the wheelchair users.

A virtual prototype is a computer simulation of a physical product that can be presented, analysed and tested from various aspects [7]. The process of 
constructing and testing of the virtual prototype is called virtual prototyping (VP) [7, 8]. In recent years, the use of VP has increased also in the clothing industry due to shortening the production time and product time to market [9]. The advantage of VP of garments is in the evaluation of their appearances and fit without producing real prototypes. The commercial software packages for CAD of garments provide 3D virtual simulation modules and 3D Parametric Mannequins (3DPM) in a standing posture. The 3DPM can easily be changed into a limited number of different body sizes, shapes and standing postures. In the research by K. Ancutiene the real and virtual garment fit was evaluated regarding the ease and strain deformations of the straight dress [10]. The results showed that static virtual body posture don't provide the right information about garment ease and strain. Producers of the 3D human body scanners usually offer computerised software for visualization of the scanned (standing) 3D body model and automatic extraction of the anthropometric dimension based on Standard ISO 8559 [11]. However, this software cannot represent scanned sitting body and extract body dimensions automatically. The standard human body posture, used in size surveys, is a standing posture with the legs and arms slightly abducted, and elbows and hand joints slightly bent to allow measurement of the anthropometric dimensions [12]. Some researchers have pointed out that clothing VP represents a problem for the nonstandard body shapes and a sitting posture [13-18]. Therefore, they used VP for the development of special garments based on scanned and $3 D$ modelled human bodies to enhance the reliability of the garments 'virtual development. A study regarding the VP of the individually adapted garments for paraplegics based on the 3D scans of the Fully Mobile Persons (FMP) in a sitting posture [19]. The experiences gained from this study enabled us to include paraplegics within this research.

As Thoren reports, most of the disabled do not fit into the current size system, i.e. their body dimensions differ from those represented in the size systems and have problems when purchasing clothing in regular stores [5]. Therefore, she presented a method for user-oriented product development in order to understand the disabled and possibly solve their problems. The comparative analyses between the anthropometric dimensions of the disabled and non-disabled showed significant differences between these two groups [20-22]. Consequently, the disabled users need specially adapted ergonomic garments. Researches in the field of ergonomic garments for wheelchair users were carried out to improve their daily living activities, such as dressing/undressing, going to the toilet and bathing, and to enhance the garments' thermal comfort [23-26]. According to studies garments for disabled users should not only be based on various design, fashion and comfort concepts, but also on particular medical problems $[1,19,27]$.
According to the above-mentioned and the fact that advances in complex medical rehabilitation allow people with spinal cord injuries to return to a wider social and working environment, the consequence is an increased number of wheelchair consumers regarding the ergonomic garments.

The purpose of this study was to evaluate the suitability of the 3D scanning and Virtual Prototyping technologies in the development process of the ergonomic garments for the Immobile People (IMP) using a wheelchair. In this study, the chair prototype for scanning of the Immobile People (IMP) was developed and scanning was carried out of the Fully Mobile Persons (FMP) and Immobile Persons (IMP). The Manual Measurements (MM) and scanned 3D body models' Virtual Measurements (VM) were performed for the FMP and IMP. The comparative analysis between the manual and virtual measurements was performed in order to find out if the loss of the IMP body balance influences the accuracy of the 3D body models needed for the VP. The custom-made ergonomic garments for the paraplegic wheelchair users were developed based on a questionnaire survey and virtually measured dimensions of the $3 D$ scanned bodies using the Virtual Prototyping technology and tested in the real environment.

\section{EXPERIMENTAL WORK}

\section{Development of a chair prototype for scanning} of the wheelchair users

The development of a chair prototype for scanning of the IMP was based on the fact that, due to the individual's height of the spine deformation, the chair should have a spine backrest adjustable to different heights, and arm and leg backrests to support the body balance when sitting. In addition, the seat should have a small slope backwards to prevent slip of the body off the chair.

The construction of the chair consists of aluminium profiles and enables setting of all depths and heights with the aim of adjustment to the dimensions of the individual and the height of their spine deformation. The chair is assembled with screw connections, which allows flawless transportation to different scanning locations. The adjustable spine, arm and leg backrests and extra head backrest of the scanning chair serve to support the wheelchair users' balance during sitting and enables the setting of equal body postures of individuals during scanning, figure 1 (a).

\section{D scanning}

In this research scanning was performed of the six female persons. Among them there were three FMP and three IMP, aged between 18 and 49 years, with different body heights, weights and BMI. The basic data of the scanned persons are presented in table 1. The scanning was carried out using an Artec Eva 3D optical hand scanner. During scanning persons sat with bended knees at 90 degrees and slightly upraised hands, breathing normally and wearing a thin, white bodysuit without sleeves, sewn for the 


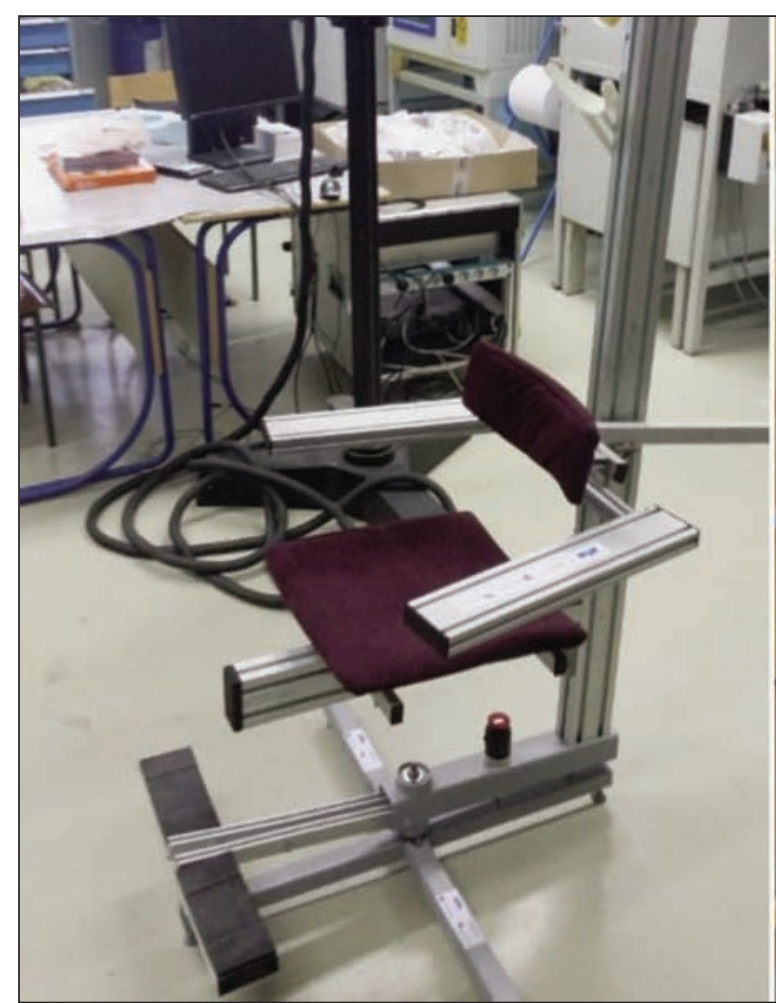

a

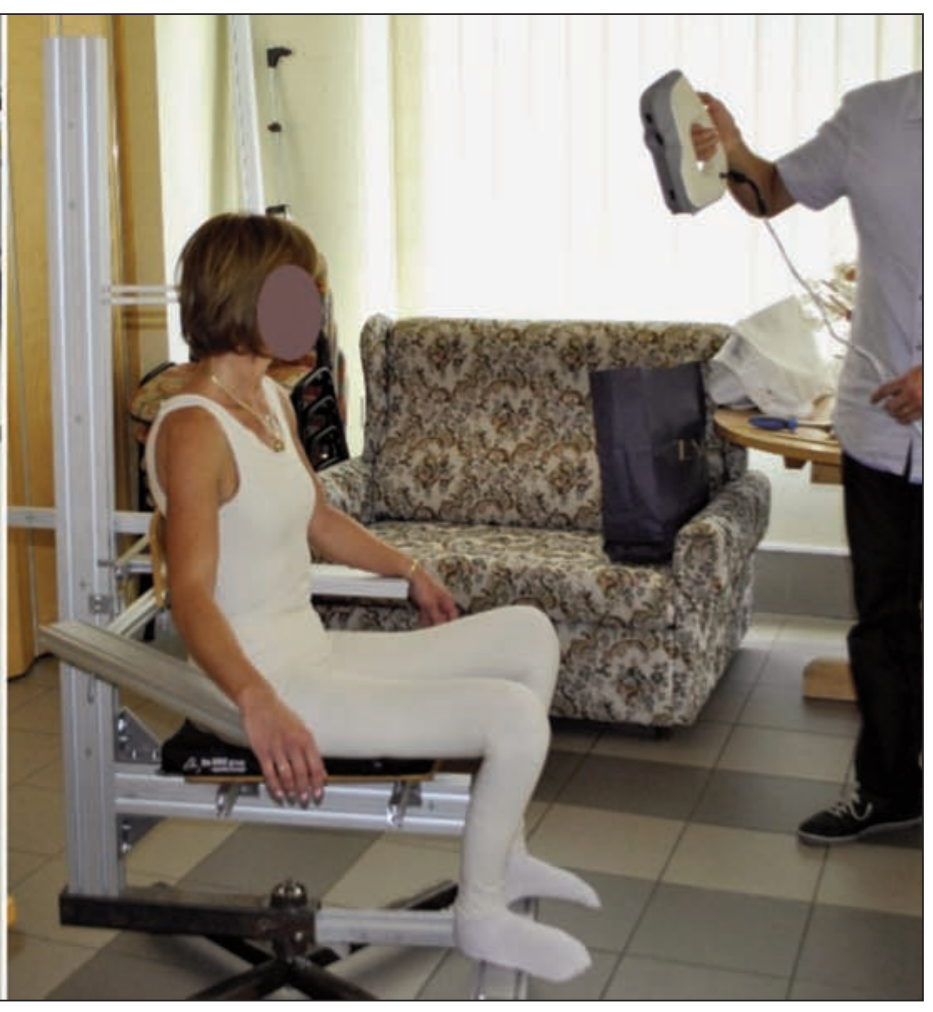

b

Fig. 1. The chair prototype for scanning of the IMP (a) and application (b)

Table 1

BASIC DATA OF THE SCANNED FMB AND IMP

\begin{tabular}{|c|c|c|c|c|c|}
\hline & $\begin{array}{l}\text { Persons } \\
\text { notations }\end{array}$ & Age & $\begin{array}{l}\text { Body } \\
\text { height } \\
(\mathrm{cm})\end{array}$ & $\begin{array}{c}\text { Weight } \\
\text { (kg) }\end{array}$ & BMI \\
\hline \multirow{3}{*}{ 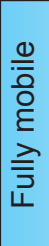 } & $\begin{array}{l}\text { Scanned person } 1 \\
\text { (FMP1) }\end{array}$ & 28 & 164 & 50 & 18.59 \\
\hline & $\begin{array}{l}\text { Scanned person } 2 \\
\text { (FMP2) }\end{array}$ & 27 & 168 & 72 & 25.51 \\
\hline & $\begin{array}{l}\text { Scanned person } 3 \\
\text { (FMP3) }\end{array}$ & 23 & 168 & 57 & 20.20 \\
\hline \multirow{3}{*}{$\begin{array}{l}\frac{\varrho}{\bar{\sigma}} \\
\frac{0}{0} \\
\frac{\varepsilon}{E} \\
\underline{E}\end{array}$} & $\begin{array}{l}\text { Scanned person } 1 \\
\text { (IMP1) }\end{array}$ & 39 & 157 & 65 & 26.37 \\
\hline & $\begin{array}{l}\text { Scanned person } 2 \\
\text { (IMP2) }\end{array}$ & 49 & 170 & 50 & 17.30 \\
\hline & $\begin{array}{l}\text { Scanned person } 3 \\
\text { (IMP3) }\end{array}$ & 18 & 168 & 53 & 18.78 \\
\hline
\end{tabular}

purpose of scanning, figure 1 (b). Scanning with upraised arms and with spacing between the thighs was carried out for the purpose of garments' VP. The optical scanning was performed from different angles and heights in order to digitize a complete person. A real-time surface mesh of the individual scan was captured using the Artec Studio 9.0 software. The processing techniques of the 3D human body mesh modelling and surface reconstruction techniques were involved to obtain the sitting 3D body models.

\section{Body measurements}

In order to evaluate the suitability of the 3D scanning technology and developed chair prototype the Manual
Measurements (MM) and Virtual Measurements (VM) were performed of the fully mobile and immobile persons. Examined were those body dimensions which showed greater deviations during the preliminary test scanning of the FMP. The fourteen body dimensions were measured according to the Standard ISO 8559 (ISO, 1989): Neck girth, breasts' girth, waist girth, hips' girth, thigh girth, knee girth, calf girth, upper arm girth, elbow girth, forearm girth, hips' depth, total crotch length, thigh length, knee height and additional body dimension 'waist to thigh depth' that Standard ISO 8559 does not specify. During manual measurements, using a measuring tape, locations of the body dimensions, anthropometrical landmarks and standard procedure for the human body measuring were taken into account according to the Standard (ISO, 1989). All dimensions of the limbs were measured on the left limbs. Due to a sitting posture, the hips' girth was measured transversely as a maximum girth around the buttocks, the knee girth was measured for bended knees at 90 degrees, the thigh length as a frontal length from the bend of the thigh to the knee girth, and the knee height as a frontal length from the knee girth to the ankle girth. The additional body dimension 'waist to thigh depth' was measured from the waistline to the thigh bend (perpendicular to the middle of the thigh). The manual measurements were rounded up to the nearest half a centimetre.

The VM of the scanned 3D body models were performed at the same locations as described for the MM using the measuring tools of the OptiTex 3D system, as shown in figure 2.

The described fifteen MM and VM were measured in order to perform the statistical analysis of the 


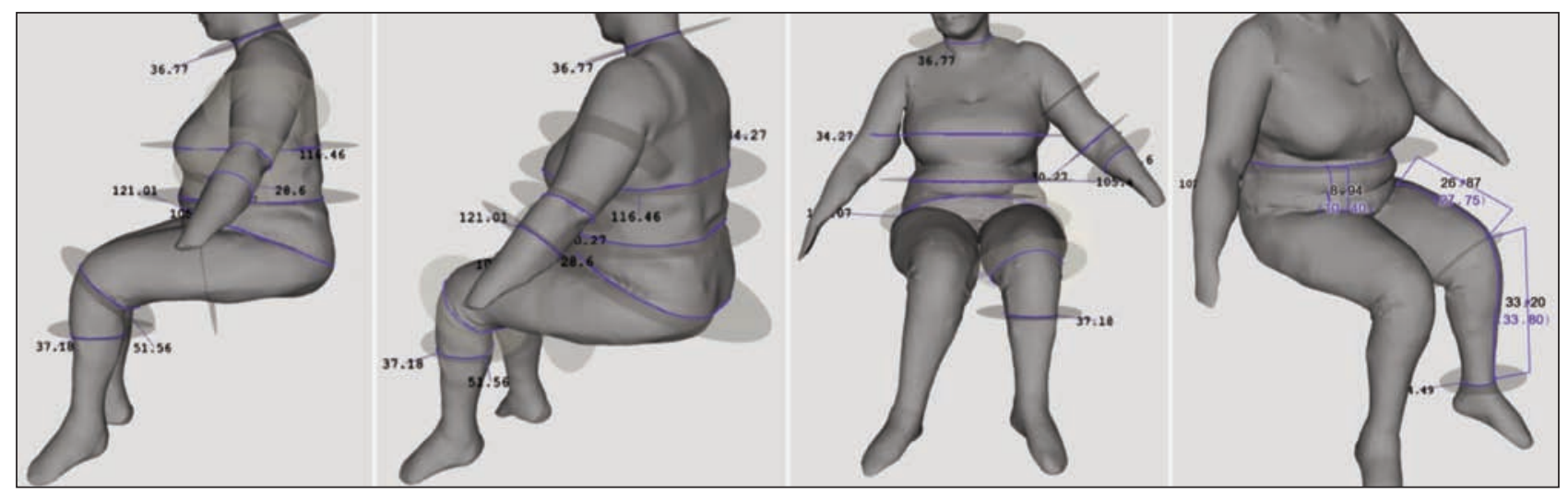

Fig. 2. Example of virtual measuring of the sitting 3D body model

measurements for the FMP and IMP. Therefore, three measurements were performed of each body dimension.

\section{Data analysis}

The average values $(\bar{x})$, Standard Deviations (SD) and Coefficients of Variation (CV) were calculated for the MM and VM. The differences were calculated between the mean values of the MM of the real sitting bodies and VM of the scanned sitting 3D body models $\left(D_{M M-V M}\right)$. A positive value $(+)$ means that the $\mathrm{MM}$ is higher than the VM and a negative value (-) reverse.

In order to find out if the used 3D scanning technology and scanning chair prototype, influenced the accuracy of the $3 \mathrm{D}$ body models, according to the balance loss of the IMP, a comparison between the MM and VM for the FMP and IMP was carried out using the F-test and t-test. The F-test procedure was used to evaluate the variances of the MM and VM. Hypothesis $\mathrm{H}_{0}: \sigma_{M M}{ }^{2}=\sigma_{V M}{ }^{2}$ was tested according to $\alpha=0.05$ confidence level. The student t-test was conducted to find if there were statistically significant differences between the mean values of the MM and VM for the FMP and IMP. Hypothesis $\mathrm{H}_{0}$ : MM = VM was tested according to $\alpha=0.05$ confidence level.

\section{Interview of the wheelchair users regarding garments}

The interviewing of the paraplegic wheelchair users was conducted to confront their problems regarding the regular garments, and their needs and wishes regarding the adapted ergonomic garments. A poll was conducted in Slovenia among 45 interviewees, both male (29) and female (16) paraplegics using a wheelchair from 2 to 45 years. The age of the respondents ranged between 20 and 64 years old.

The results of the poll showed that there is a general need in the individually adapted garments. Namely, the IMP had a strong desire regarding the specialised Fashion Studios producing custom-made garments adapted to a sitting posture. In addition, it was found that garments, besides the ergonomic pattern design, should also comprise functional demands regarding their accompanying health problems. The results, targeted to the three exploratory garments (jacket, pants, dress), are summarised briefly into specific demands as follows: The jacket should be wide enough across the shoulders; long at the front part to the thighs and at the back to the wheelchair (covered lumbar region due to frequent urinary tract infections); narrower sleeves of the correct length (sleeves rubbing from the wrist to the elbow due to friction with the wheelchair' wheels); zip fastening; water and wind impermeable textile materials and thermal comfort in the winter time. The pants should be lower at the front part and higher at the back part to the waistline; relocation of the knee-line to a sitting posture and extension of the pants legs; zip fastening and functional solutions for easy dressing; careful design considerations of the pants' legs due to excessive pressure on the body (impedes blood flow) or pants' width around hips, under the buttocks and thighs (pants wrinkling may cause skin irritations and inflammations in contacts with a wheelchair, pressure sores) and around the calf for those who need a urine bag; reinforced pants at the waist due to pulling on legs; durable textile materials. A dress should be wide enough across the shoulders, long enough (to cover muscularly impaired legs) with levelled dress length; deepened armholes for easy upper limbs movement; narrower sleeves (like for the jacket); careful design considerations due to dress wrinkling (like for the pants) and jamming into wheels of a wheelchair; front zip fastening and functional solutions for easy dressing. For all three garments, there was a request to be without the usual pockets or at locations to have a useful function, to have functional solutions for those who have pains in hands and impaired hands' mobility, and the extremely exposed request to be of an aesthetic appearance.

\section{Virtual development of ergonomic garments' prototypes for wheelchair users}

The virtual development of ergonomic garments' prototypes, i.e. jacket, dress and pants, was based on the virtually measured dimensions of the scanned 3D body models of the IMP. In the process of garments' virtual development the defined specific demands were taken into account, as well as the special needs and wishes of the individual IMP. The custom-made 
jacket pattern design was developed for the IMP1, the dress for the IMP2 and the pants for the IMP3. The garments' virtual prototypes were fitted on the parametric 3D mannequin (standing) and on the scanned 3D body models (sitting) to present the fitting differences and importance of the Virtual Prototyping technology for a sitting posture. The construction of garments' pattern designs were performed using the OptiTex PDS system and 3D garments' Virtual Prototyping by using the module 3D of the OptiTex PDS system.

\section{Fit and wear trials of ergonomic garments}

In order to inspect the suitability of the 3D scanning and virtual simulation technologies in the development process of the ergonomic garments for the IMP, the real garments were sewn according to the virtually developed prototypes of the ergonomic garments' pattern designs without any fit trials of the real persons, as usual. The assessment of the visual appearances of the garments fit to the tested persons was carried out for those body dimensions of which statistically significant differences were confirmed between the MM and VM.

The IMP wore garments for two weeks in a real environment and performed their usual daily living activities depending on the intended use of the garments. After that, they give a written subjective opinion regarding the ergonomic garments.

\section{RESULTS AND DISCUSSION}

\section{Measurement results of the MM and VM}

The average values (), Standard Deviations (SD) and Coefficients of Variation (CV) for both the MM of the real sitting bodies and the VM of the scanned sitting 3D body models of the FMP and IMP are collated in tables 2 and 3 . The calculated differences between the mean values of the MM and VM are presented in table 3.

The Standard Deviation for the MM of the FMP ranges between $0.29 \mathrm{~cm}$ and $0.50 \mathrm{~cm}$, whilst it was between $0.29 \mathrm{~cm}$ and $1.00 \mathrm{~cm}$ for the IMP, table 2 . The Standard Deviation for the VM of the FMP ranges between $0.05 \mathrm{~cm}$ and $0.81 \mathrm{~cm}$ and for the IMP it was between $0.03 \mathrm{~cm}$ and $0.80 \mathrm{~cm}$, table 3 .

The Coefficients of Variation for the MM of the FMP ranged between $0.30 \%(B G)$ and $2.59 \%\left(\mathrm{~W}-\mathrm{TD}_{\mathrm{f}}\right)$, whilst for the IMP it was between $0.26 \%$ (BG) and $2.84 \%\left(\mathrm{~W}-\mathrm{TD}_{\mathrm{f}}\right)$, Table 2. In addition, the Coefficients of Variation for the manually measured $W-T D_{f}$ had the highest value for all tested persons (FMP and IMP). The Coefficient of Variation for the VM of the FMP ranged between $0.05 \%$ (FAG) and $6.11 \%$ $\left(\mathrm{W}-\mathrm{TD}_{\mathrm{f}}\right)$ and for the IMP between $0.06 \%$ (HG, WG) and $4.57 \%\left(\mathrm{~W}-\mathrm{TD}_{\mathrm{f}}\right)$, Table 3 . The highest values of the CV for the VM were observed for the measured $\mathrm{W}-\mathrm{TD}_{\mathrm{f}}$ for four measured persons (FMP1, FMP2, FMP3, IMP4).

\begin{tabular}{|c|c|c|c|c|c|c|c|c|c|c|c|c|c|c|c|c|c|c|c|}
\hline \multicolumn{20}{|c|}{ MANUAL MEASUREMENTS (MM) OF THE BODY DIMENSIONS OF THE FMP AND IMP } \\
\hline \multirow{3}{*}{$\begin{array}{c}\text { Body } \\
\text { dimensions }\end{array}$} & \multirow{3}{*}{ Sign } & \multicolumn{18}{|c|}{ Manual Measurements (MM) / cm } \\
\hline & & \multicolumn{3}{|c|}{ FMP1 } & \multicolumn{3}{|c|}{ FMP2 } & \multicolumn{3}{|c|}{ FMP3 } & \multicolumn{3}{|c|}{ IMP1 } & \multicolumn{3}{|c|}{ IMP2 } & \multicolumn{3}{|c|}{ IMP3 } \\
\hline & & $\begin{array}{c}\bar{x} \\
(\mathrm{~cm})\end{array}$ & $\begin{array}{c}\mathrm{SD} \\
(\mathrm{cm}) \\
\end{array}$ & $\begin{array}{l}\mathrm{CV} \\
(\%) \\
\end{array}$ & $\begin{array}{c}\bar{x} \\
(\mathrm{~cm})\end{array}$ & $\begin{array}{c}\mathrm{SD} \\
(\mathrm{cm}) \\
\end{array}$ & \begin{tabular}{|l|}
$\mathrm{CV}$ \\
$(\%)$
\end{tabular} & $\begin{array}{c}\bar{x} \\
(\mathrm{~cm})\end{array}$ & $\begin{array}{c}\mathrm{SD} \\
(\mathrm{cm})\end{array}$ & $\begin{array}{l}\mathrm{CV} \\
(\%)\end{array}$ & $\begin{array}{c}\bar{x} \\
(\mathrm{~cm})\end{array}$ & $\begin{array}{l}\mathrm{SD} \\
(\mathrm{cm}) \\
\end{array}$ & $\begin{array}{l}\mathrm{CV} \\
(\%) \\
\end{array}$ & $\begin{array}{c}\bar{x} \\
(\mathrm{~cm})\end{array}$ & $\begin{array}{c}\mathrm{SD} \\
(\mathrm{cm}) \\
\end{array}$ & \begin{tabular}{|l|}
$\mathrm{CV}$ \\
$(\%)$ \\
\end{tabular} & $\begin{array}{c}\bar{x} \\
(\mathrm{~cm})\end{array}$ & $\begin{array}{c}\mathrm{SD} \\
(\mathrm{cm}) \\
\end{array}$ & $\begin{array}{l}\text { CV } \\
(\%) \\
\end{array}$ \\
\hline Neck girth & NG & 30.33 & 0.29 & 0.95 & 34.33 & 0.29 & 0.84 & 31.33 & 0.29 & 0.92 & 36.33 & 0.29 & 0.79 & 32.17 & 0.29 & 0.90 & 31.83 & 0.29 & 0.91 \\
\hline Breasts girth & BG & 79.67 & 0.29 & 0.36 & 97.17 & 0.29 & 0.30 & 84.83 & 0.29 & 0.34 & 111.33 & 0.29 & 0.26 & 80.17 & 0.58 & 0.72 & 82.83 & 0.29 & 0.35 \\
\hline Waist girth & WG & 68.17 & 0.29 & 0.42 & 82.83 & 0.29 & 0.35 & 69.67 & 0.29 & 0.41 & 100.33 & 0.29 & 0.29 & 68.33 & 0.29 & 0.42 & 65.50 & 0.50 & 0.76 \\
\hline $\begin{array}{l}\text { Hips girth } \\
\text { (transverse) }\end{array}$ & $H G_{t r}$ & 99.00 & 0.50 & 0.51 & 115.50 & 0.50 & 0.43 & 100.17 & 0.29 & 0.29 & 114.17 & 0.76 & 0.67 & 92.17 & 0.76 & 0.83 & 94.17 & 0.29 & 0.31 \\
\hline Thigh girth & TG & 55.83 & 0.29 & 0.52 & 64.17 & 0.29 & 0.45 & 55.33 & 0.29 & 0.52 & 61.83 & 0.29 & 0.47 & 49.83 & 0.29 & 0.58 & 51.17 & 0.29 & 0.56 \\
\hline $\begin{array}{l}\text { Knee girth } \\
\text { (bend knee) }\end{array}$ & $K G_{b k}$ & 36.83 & 0.29 & 0.78 & 42.17 & 0.29 & 0.68 & 7.33 & 0.29 & 0.77 & 45.17 & 0.29 & 0.64 & 38.33 & 0.29 & 0.75 & 39.67 & 0.29 & 0.73 \\
\hline Calf girth & CG & 35.83 & 0.29 & 0.81 & 39.83 & 0.29 & 0.72 & 36.33 & 0.29 & 0.79 & 37.83 & 0.29 & 0.76 & 26.33 & 0.29 & 1.10 & 32.67 & 0.58 & 1.77 \\
\hline $\begin{array}{l}\text { Upper arm } \\
\text { girth }\end{array}$ & UAG & 24.17 & 0.29 & 1.19 & 32.17 & 0.29 & 0.90 & 25.83 & 0.29 & 1.12 & 37.67 & 0.29 & 0.76 & 27.17 & 0.29 & 1.06 & 26.17 & 0.29 & 1.10 \\
\hline Elbow girth & EG & 20.83 & 0.29 & 1.39 & 26.87 & 0.29 & 1.08 & 23.83 & 0.29 & 1.21 & 28.83 & 0.29 & 1.00 & 23.83 & 0.29 & 1.21 & 23.33 & 0.29 & 1.24 \\
\hline $\begin{array}{l}\text { Forearm } \\
\text { girth }\end{array}$ & FAG & 20.33 & 0.29 & 1.42 & 24.83 & 0.29 & 1.16 & 22.83 & 0.29 & 1.26 & 28.33 & 0.29 & 1.02 & 23.83 & 0.29 & 1.21 & 23.83 & 0.29 & 1.21 \\
\hline $\begin{array}{l}\text { Hips depth } \\
\text { (waist to } \\
\text { seat) }\end{array}$ & $H D_{w-s}$ & 27.17 & 0.29 & 1.06 & 30.17 & 0.29 & 0.96 & 26.83 & 0.29 & 1.08 & 23.17 & 0.29 & 1.25 & 23.17 & 0.29 & 1.25 & 25.17 & 0.29 & 1.15 \\
\hline $\begin{array}{l}\text { Waist to } \\
\text { thigh depth } \\
\text { (front) }\end{array}$ & W- $T D_{f}$ & $f 14.33$ & 0.29 & 2.01 & 11.17 & 0.29 & 2.59 & 11.33 & 0.29 & 2.55 & 10.17 & 0.29 & 2.84 & 10.83 & 0.29 & 2.66 & 11.83 & 0.29 & 2.44 \\
\hline $\begin{array}{l}\text { Total crotch } \\
\text { length }\end{array}$ & ToCL & 70.50 & 0.50 & 0.71 & 75.17 & 0.29 & 0.38 & 73.17 & 0.29 & 0.39 & I & I & I & 1 & I & 1 & 70.00 & 1.00 & 1.43 \\
\hline Thigh length & $T L$ & 39.83 & 0.29 & 0.72 & 42.17 & 0.29 & 0.68 & 43.83 & 0.29 & 0.66 & 32.33 & 0.29 & 0.89 & 41.17 & 0.29 & 0.70 & 35.67 & 0.29 & 0.81 \\
\hline $\begin{array}{l}\text { Knee height } \\
\text { (front) }\end{array}$ & $\mathrm{KH}_{\mathrm{f}}$ & 40.17 & 0.29 & 0.72 & 42.83 & 0.29 & 0.67 & 44.17 & 0.29 & 0.65 & 32.83 & 0.29 & 0.88 & 40.17 & 0.29 & 0.72 & 37.17 & 0.29 & 0.78 \\
\hline
\end{tabular}




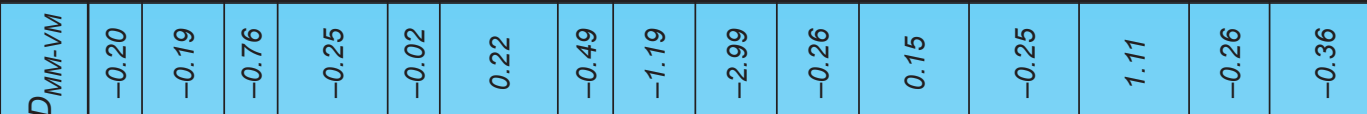

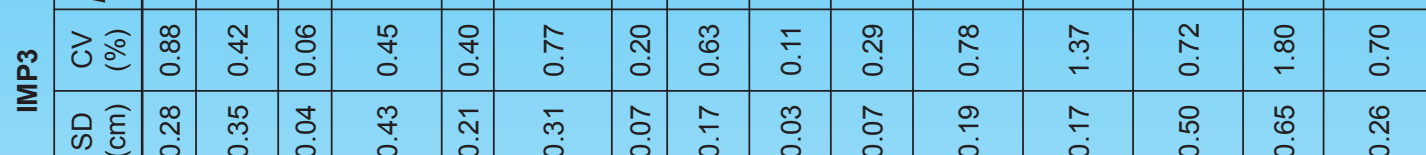

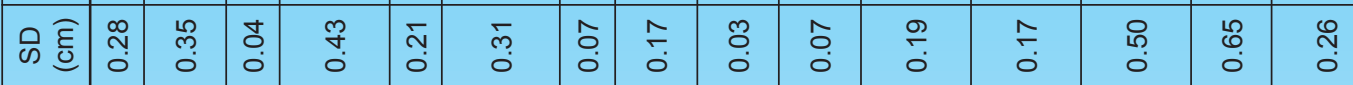

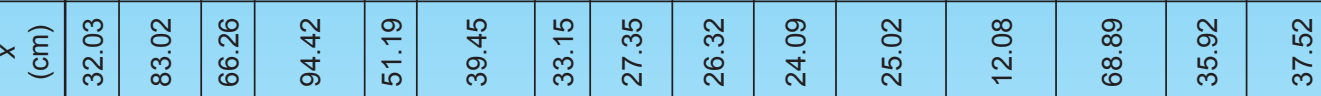

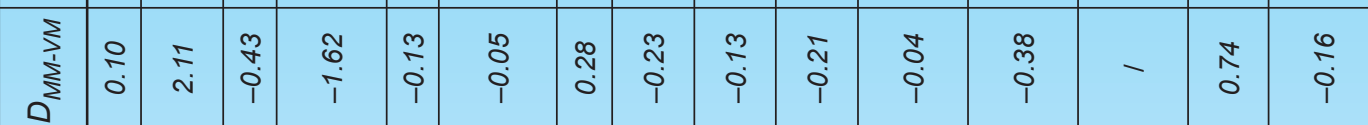

$\underline{\mathfrak{N}}$

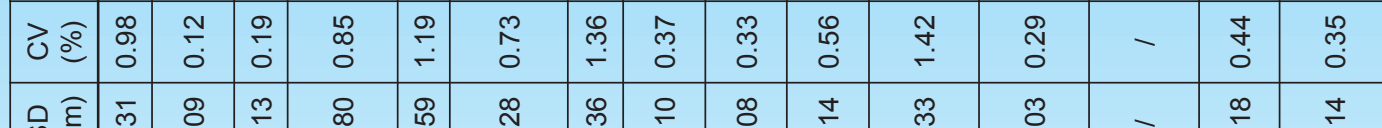

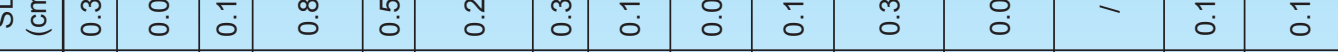

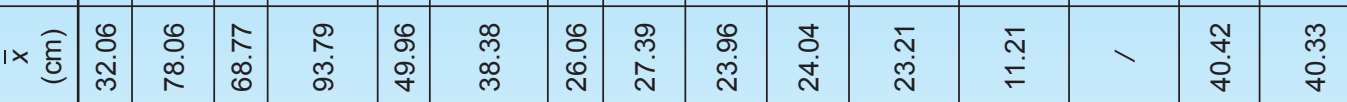

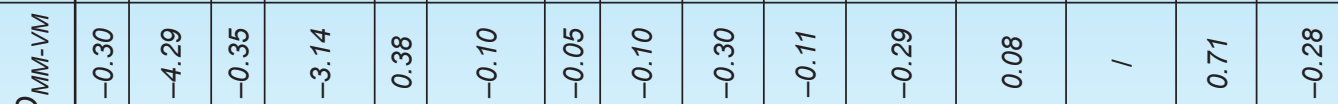
西

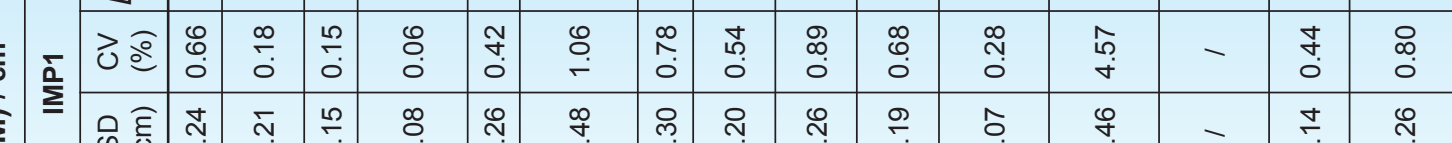

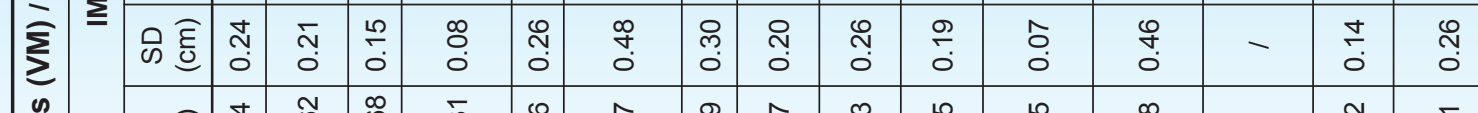

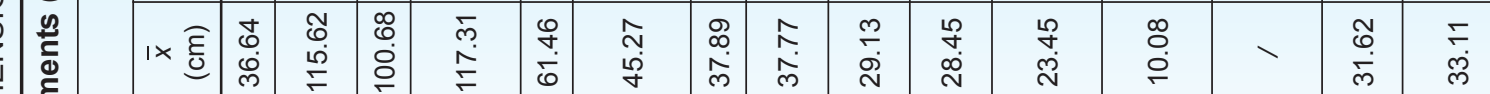

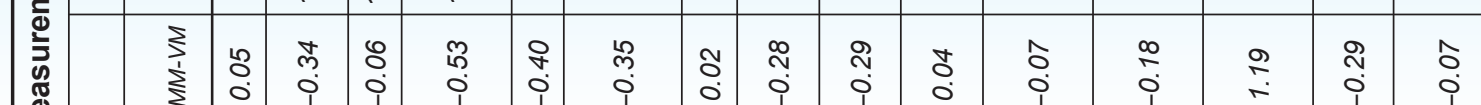

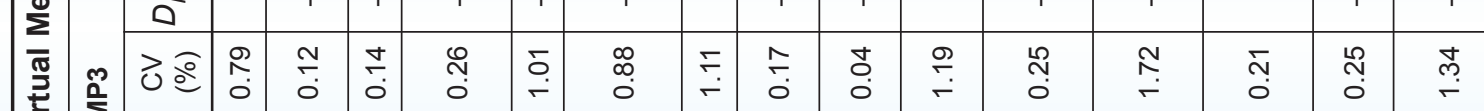

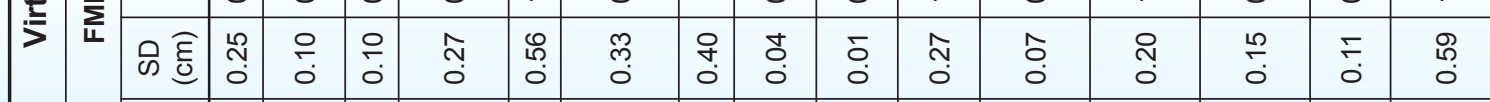

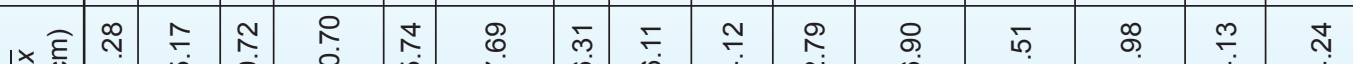

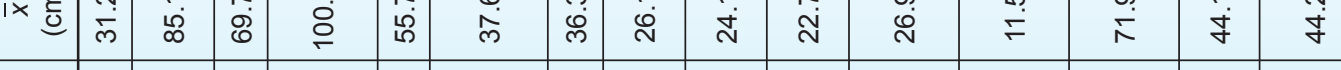

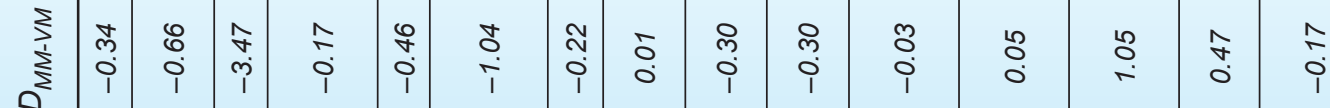

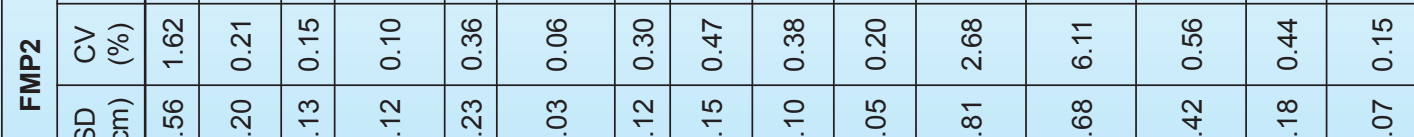

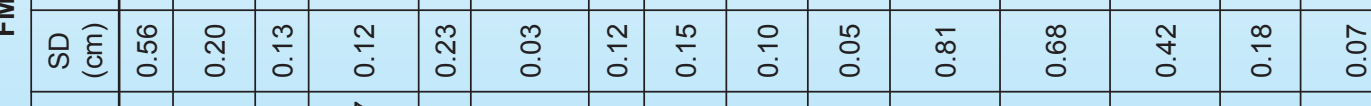

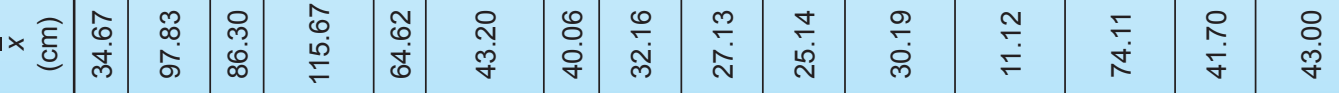

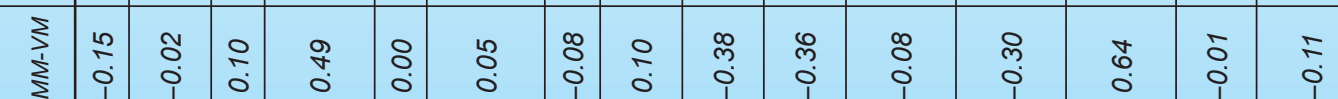

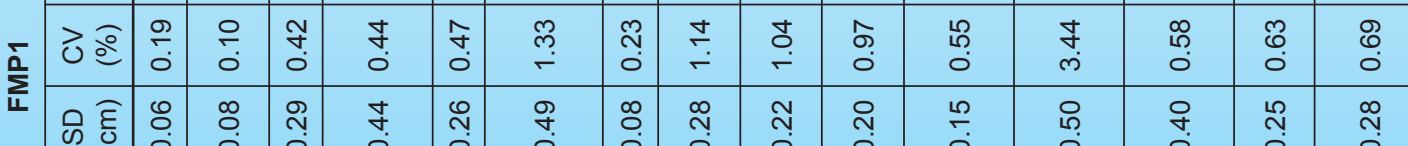

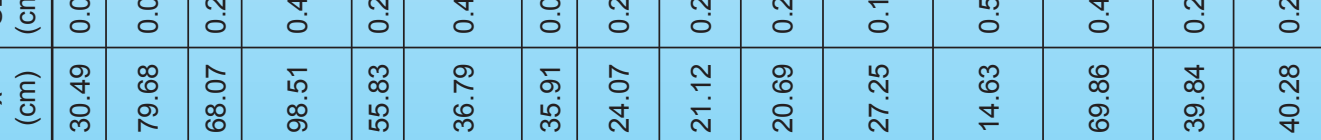

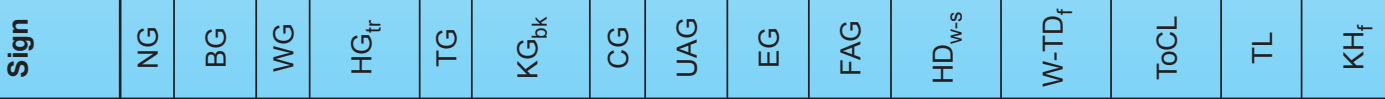

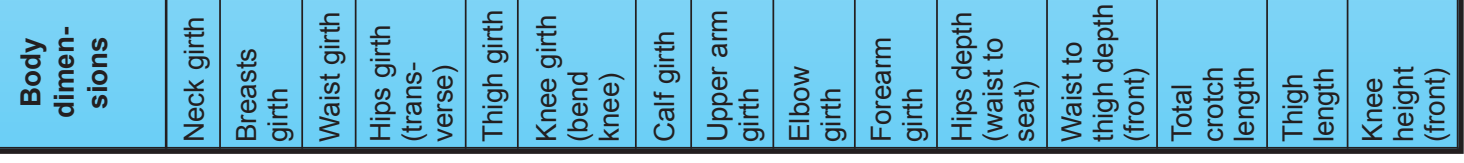


The results of the differences between the MM and VM $\left(D_{M M-V M}\right)$ showed that most of the measurements had higher value when VM were performed, therefore, they have a negative sign, table 3 . The $\mathrm{D}_{\mathrm{MM}-\mathrm{VM}}$ ranged between $-0.38 \mathrm{~cm}(\mathrm{EG})$ and $0.64 \mathrm{~cm}$ (ToCL) for the FMP1, than for the FMP2 between $-3.47 \mathrm{~cm}$ (WG) and $1.05 \mathrm{~cm}$ (ToCL), for the FMP3 between $-0.53 \mathrm{~cm}$ (HGtr) and $1.19 \mathrm{~cm}$ (ToCL). In addition, the $\mathrm{D}_{\mathrm{MM}-\mathrm{VM}}$ for the IMP1 ranged between -4.29 (BG) and $0.71 \mathrm{~cm}(\mathrm{TL})$, for the IMP2 between $-1.62 \mathrm{~cm}$ (HGtr) and $2.11 \mathrm{~cm}$ (BG) and for the IMP3 between -2.99 (EG) and $1.11 \mathrm{~cm}$ (ToCL). The latter results indicate that the slightly higher calculated differences between the MM and VM were for the IMP. This could be attributed to their first scanning and measuring of the body dimensions. The highest difference between the MM and VM was for the measure BG $(-4.29 \mathrm{~cm})$ of the IMP1. It is well-known that it can be affected by inappropriate breathing or possible breath retention during the scanning process.

Based on results of the MM and VM of the FMP and IMP it is evident that there are no obvious differences in the body dimensions whether a person is fully mobile or immobile. Therefore, it could be supposed that the used 3D scanning technology and scanning chair are suitable for scanning of the IMP.

\section{Statistical analysis regarding differences} between the MM and VM for the FMP and IMP

The results of the F-test showed that statistically significant variance of the neck girth differed for the FMP1, whilst for the FMP2 for the knee girth, forearm girth and knee height and for the FMP3 the upper arm and especially, the elbow girth, table 4. In addition, for the IMP the statistically significant differences of variances were observed for the hips' girth of the IMP1, whilst for the IMP2 it was the breasts' girth and waist to thigh depth and for the IMP3 the waist, calf and elbow girths, table 5 .

The results of the t-test confirmed that differences between the mean values of the MM and VM for the FMP1 are not statistically significant for all measured body dimensions, table 4 . The body dimension ToCL for the FMP3 showed statistically significant differences and for the FMP2 there were observed statistically significant differences for the breasts', waist and knee girths and total crotch length. The results of the t-test confirmed that differences between the mean values of the MM and VM of the IMP1 were statistically significant for the breasts' girth, hips' girth and thigh length, table 5. The breasts' girth, upper arm girth and thigh length of the IMP2 showed statistically significant differences. For the IMP3 the upper arm girth and elbow girth had statistically significant differences between the mean values of the MM and VM.

Based on the statistical results the five body dimensions for the FMP and eight for the IMP had statistically significant differences between the mean values of the MM and VM. It must be emphasised that many differences between MM and VM for the individual person were not statistically significant. Therefore, we cannot state with certainty that the accuracy of the scanning results is affected by the mobility of the person, but it could be supposed that used 3D scanning technology and the developed chair prototype are suitable for scanning of the IMP.

\section{Virtual prototyping of the ergonomic garments}

The virtual prototype of the ergonomic jacket on a standing 3D mannequin, whose dimensions were

Table 4

\begin{tabular}{|c|c|c|c|c|c|c|c|}
\hline \multicolumn{8}{|c|}{ STATISTICAL ANALYSIS REGARDING DIFFERENCES BETWEEN THE MM AND VM OF THE FMP } \\
\hline \multirow[b]{2}{*}{ Body measurements } & \multirow[b]{2}{*}{ Sign } & \multicolumn{2}{|c|}{ FMP1 } & \multicolumn{2}{|c|}{ FMP2 } & \multicolumn{2}{|c|}{ FMP3 } \\
\hline & & $\mathbf{F}_{\text {calc }}$ & $\mathrm{T}_{\text {calc }}$ & $\mathbf{F}_{\text {calc }}$ & $T_{\text {calc }}$ & $\mathbf{F}_{\text {calc }}$ & $T_{\text {calc }}$ \\
\hline Neck girth & NG & 25.77 & -0.90 & 3.78 & 0.93 & 1.36 & 0.23 \\
\hline Breasts girth & $B G$ & 13.81 & -0.10 & 2.02 & -3.26 & 8.31 & -1.93 \\
\hline Waist girth & WG & 1.03 & 0.41 & 5.11 & -19.02 & 8.31 & -0.32 \\
\hline Hips girth (transversal) & $\mathrm{HG}_{\mathrm{tr}}$ & 1.31 & 1.27 & 18.61 & -0.58 & 1.19 & -2.36 \\
\hline Thigh girth & TG & 1.22 & 0.00 & 1.53 & -2.13 & 3.79 & 1.11 \\
\hline Knee girth (bend knee) & $K G_{b k}$ & 2.86 & -0.14 & 131.58 & -6.20 & 1.32 & 1.39 \\
\hline Calf girth & CG & 12.44 & -0.44 & 5.85 & -1.24 & 1.96 & -0.07 \\
\hline Upper arm girth & UAG & 1.10 & 0.43 & 3.68 & 0.02 & 43.86 & -1.64 \\
\hline Elbow girth & EG & 1.72 & -0.81 & 4.92 & -1.82 & 833.33 & -1.72 \\
\hline Forearm girth & FAG & 2.07 & -1.76 & 32.89 & -1.80 & 1.12 & 0.17 \\
\hline Hips depth (waist to seat & $\mathrm{HD}_{\mathrm{w}-\mathrm{s}}$ & 3.70 & -0.43 & 7.86 & 0.05 & 17.99 & -0.41 \\
\hline Waist to thigh depth (front) & $W-T D_{f}$ & 3.04 & 0.90 & 5.53 & -0.12 & 2.11 & -0.89 \\
\hline Total crotch length & ToCL & 1.53 & 1.71 & 2.08 & -3.60 & 3.56 & 6.31 \\
\hline Thigh length & $\mathrm{TL}$ & 1.33 & -0.05 & 2.52 & 2.39 & 6.70 & -1.64 \\
\hline Knee height (front) & $\mathrm{KH}_{\mathrm{f}}$ & 1.09 & -0.48 & 19.69 & -1.00 & 4.20 & 0.18 \\
\hline
\end{tabular}

Note: A bolded value means that there is a statistically significant difference between the MM and VM for variance/mean value of the body measurement. 


\begin{tabular}{|c|c|c|c|c|c|c|c|}
\hline \multicolumn{8}{|c|}{ STATISTICAL ANALYSIS REGARDING DIFFERENCES BETWEEN THE MM AND VM OF THE IMP } \\
\hline \multirow[b]{2}{*}{ Body measurements } & \multirow[b]{2}{*}{ Sign } & \multicolumn{2}{|c|}{ IMP1 } & \multicolumn{2}{|c|}{ IMP2 } & \multicolumn{2}{|c|}{ IMP3 } \\
\hline & & $F_{\text {calc }}$ & $T_{\text {calc }}$ & $F_{\text {calc }}$ & $T_{\text {calc }}$ & $\mathbf{F}_{\text {calc }}$ & $\mathrm{T}_{\text {calc }}$ \\
\hline Neck girth & NG & 1.45 & -1.40 & 1.18 & -0.42 & 1.05 & -0.84 \\
\hline Breasts girth & $B G$ & 1.89 & -20.80 & 39.68 & 6.24 & 1.49 & 0.72 \\
\hline Waist girth & WG & 3.84 & -1.85 & 4.70 & -2.36 & 153.06 & -2.64 \\
\hline Hips girth (transversal) & $H G_{t r}$ & 101.74 & -7.09 & 1.09 & 2.55 & 2.21 & 0.84 \\
\hline Thigh girth & TG & 1.28 & 1.69 & 4.21 & 0.34 & 1.98 & -0.10 \\
\hline Knee girth (bend knee) & $\mathrm{KG}_{\mathrm{bk}}$ & 2.76 & 0.31 & 1.05 & -0.20 & 1.12 & -0.89 \\
\hline Calf girth & CG & 1.04 & 0.22 & 1.51 & -1.05 & 75.19 & -1.45 \\
\hline Upper arm girth & UAG & 2.02 & -0.51 & 8.22 & 3.54 & 2.83 & -6.12 \\
\hline Elbow girth & EG & 1.24 & -1.32 & 13.23 & -0.73 & 92.59 & -17.82 \\
\hline Forearm girth & FAG & 2.26 & -0.57 & 4.55 & -1.12 & 17.01 & -1.50 \\
\hline Hips depth (waist to seat & $H D_{w-s}$ & 18.80 & -1.68 & 1.31 & 0.17 & 2.20 & 0.73 \\
\hline Waist to thigh depth (front) & $W-T D_{f}$ & 2.55 & -0.27 & 80.65 & -2.27 & 3.05 & -1.28 \\
\hline Total crotch length & ToCL & l & l & 1 & I & 4.07 & 1.72 \\
\hline Thigh length & $\mathrm{TL}$ & 4.25 & 3.85 & 2.63 & 3.80 & 4.99 & 0.63 \\
\hline Knee height (front) & $\mathrm{KH}_{\mathrm{f}}$ & 1.20 & -1.24 & 4.19 & -0.88 & 1.21 & -1.58 \\
\hline
\end{tabular}

Note: A bolded value means that there is a statistically significant difference between the MM and VM for variance/mean value of the body measurement.

adjusted according to the virtually measured dimensions of the IMP1, and on the scanned 3D body model of the IMP1 is presented in figure 3 . The development of the fitted jacket pattern design (to avoid unpleasant jacket folding on thighs and around the torso) with the easy dressing need (easier impaired hands' mobility) based on the intermediate virtual fitting of the jacket on the 3D body model (IMP1) to adapt the sizes and shapes of the pattern pieces to the body features of this specific person. In figure 3 it is clearly visible that development of the ergonomic jacket pattern design is not possible for a standing posture regarding the needed jacket fit and length on the front and back parts. The jacket has a flexible upper back with a rubber band to enhance the comfort during movement with a wheelchair, figure 3 . The jacket is fastened with a zip and invisible magnetic buttons for easier buttoning, including the hood. The sleeves have a zip above the elbow, therefore, the bottom parts are removable. The purpose is to change sleeves in the case of damage due to friction with the wheels of a wheelchair.

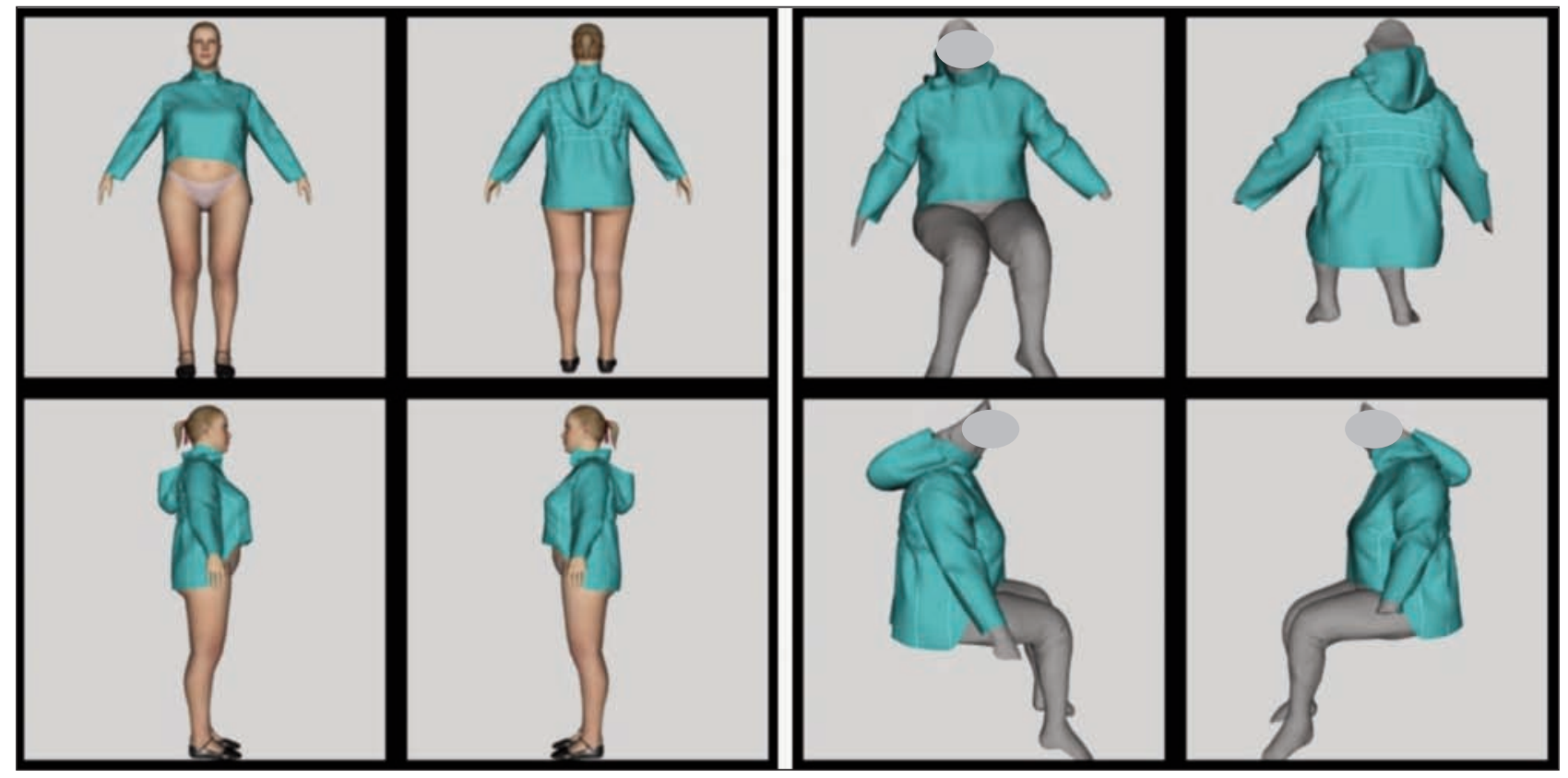

Fig. 3. The virtual prototype of the ergonomic jacket on the standing $3 \mathrm{D}$ mannequin and scanned $3 \mathrm{D}$ body model of the IMP1 


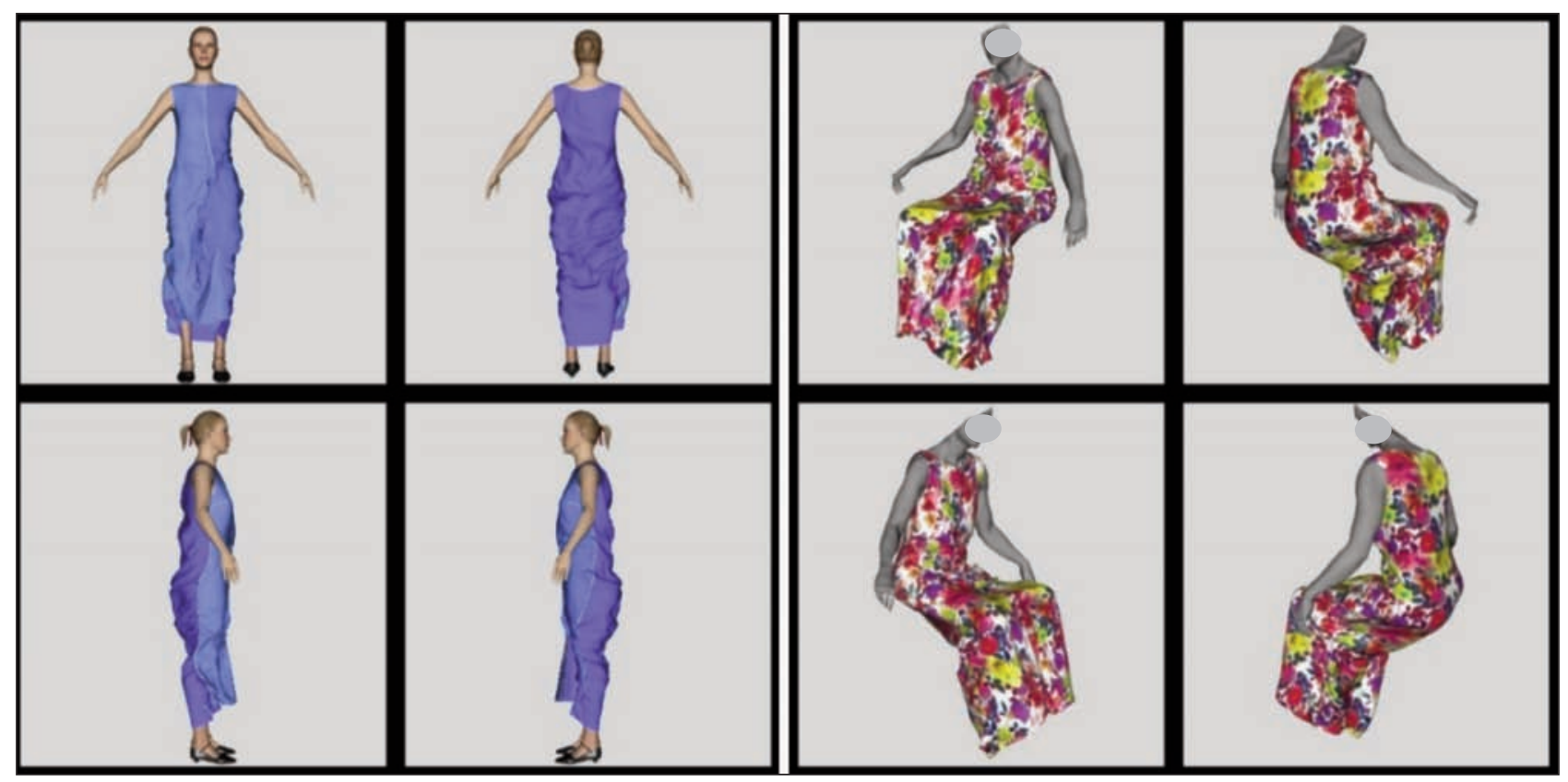

Fig. 4. The virtual prototype of the ergonomic dress on the standing 3D mannequin and scanned $3 \mathrm{D}$ body model of the IMP2

In order to develop the ergonomic dress pattern design for a sitting posture the Virtual Prototyping proved to be an extremely useful tool. The needs and wishes of the IMP2 on the long, aesthetic, slightly flared dress on the length (to cover muscularly impaired legs) and easy dressing/handling with the long dress for movement to another seat or with a wheelchair were considered. The dress front basic template for a standing posture was adapted to a sitting posture by taking the additional dimensions of the scanned 3D body model (IMP2). Many steps of the intermediate simulations were performed to achieve a satisfactory dress appearance and ergonomically adapted dress pattern design to a sitting posture, respectively, figure 4 . It is apparent that the dress does not fit the standing 3D mannequin, whilst the appropriate dress fit to the scanned 3D body model of the IMP2 can be observed in figure 4 . The dress has at the front middle a gusset from the knees to the bottom, which expands the dress additionally. The dress is fastened at the front with a zip. The gusset can be closed by a zip to avoid hooking of the dress in the wheels of a wheelchair during movement. The dress can be gathered up to the waist with the help of belts sewn inside the dress to facilitate dressing, moving in/out of the wheelchair, and use of the toilet.

The virtual prototype of the narrower pants with easy dressing zip solution (easier impaired hands' mobility) without pockets was developed for the IMP3, figure 5. In the construction procedure, the body dimension

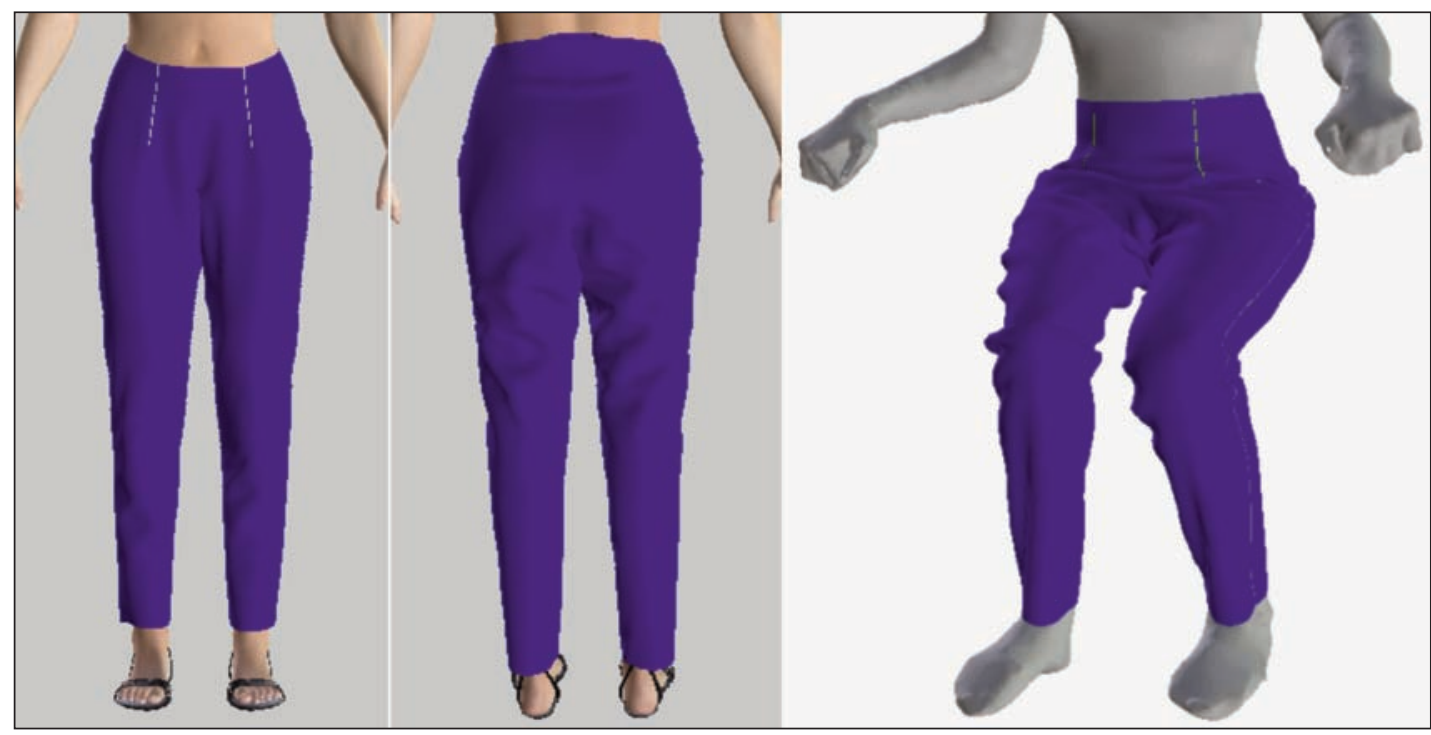

Fig. 5. The virtual prototype of the ergonomic pants on the standing 3D mannequin and scanned 3D body model of the IMP3 


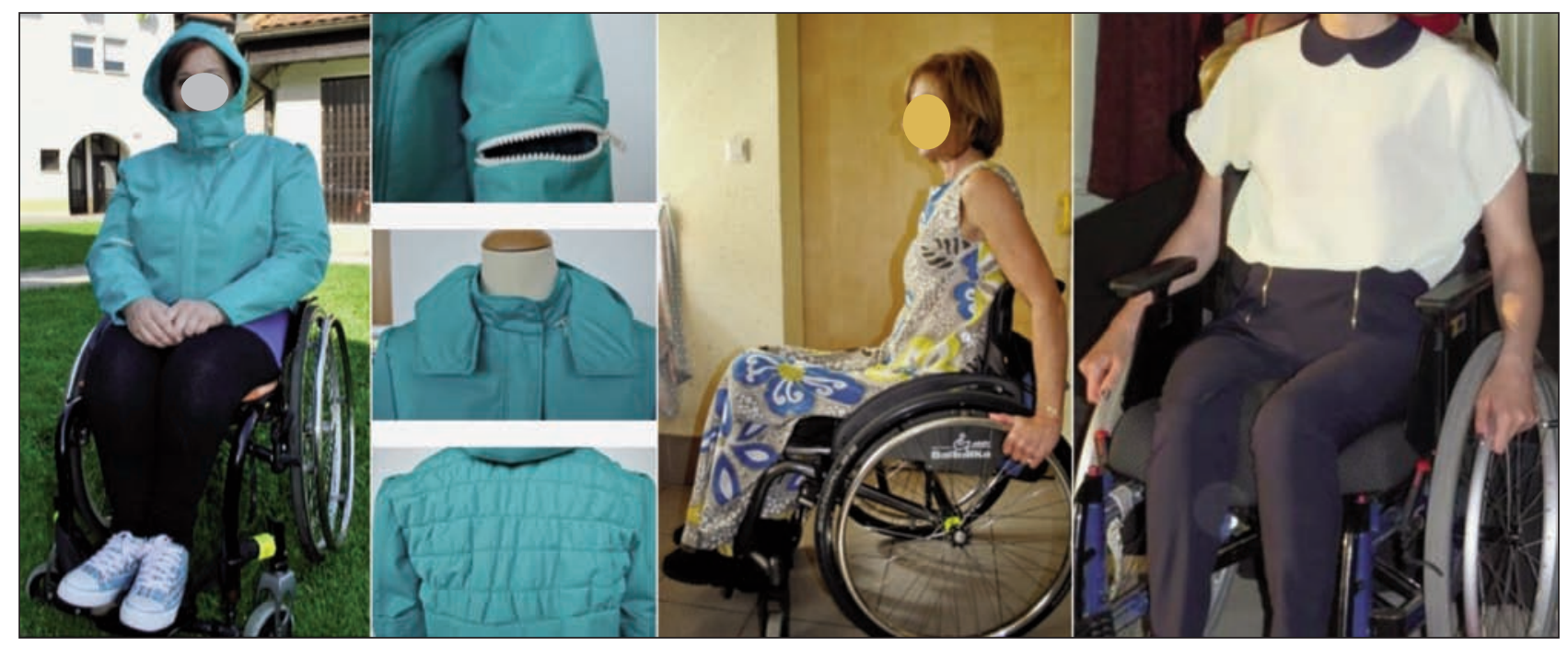

Fig. 6. The ergonomic garments fitted on the IMP

$\mathrm{W}-\mathrm{TD}_{\mathrm{f}}$ was introduced to obtain the appropriate pants height on the front part, and $\mathrm{TL}$ and $\mathrm{KH}_{\mathrm{f}}$ instead of the usual body dimension (outside leg length) to obtain the appropriate location of the knee-line and pants length. Using the Virtual Prototyping the fastening solutions were inspected with the normal zip, prolonged zip and two zips. The virtual comparison of the pants with different fastenings showed that the maximum volume for (un)dressing was obtained in the case of two zips. The zips have greater aesthetic decorative closures for easier handling. The pants in the interior have a reinforced waist region with longer loops for easy dressing. The pants' design has slightly shortened legs. In figure 5 it can be observed that the narrower pants design does not fit the standing 3D mannequin, especially in the waistline and at the back part under the buttocks. Although the dimensions of the $3 \mathrm{D}$ mannequin were set up due to the dimensions of the scanned $3 \mathrm{D}$ body model of the IMP3, the pants on a standing posture look to have much more width around the legs compared to a sitting posture. These differences are the result of the ergonomically adjusted pants ' pattern design to a sitting posture.

\section{Fit and wear assessment of the ergonomic garments}

The custom-made ergonomic garments' pattern designs adapted to a sitting posture were developed by using the virtual simulation technologies. The garments, sewn without any fit trials of the IMP, are presented in the figure 6 .

The jacket pattern design was constructed according to the two body dimensions that had statistically significant differences between the MM and VM. These were breasts' and hips' girth. The VM of the breast girth was higher by $4.29 \mathrm{~cm}$ compared to the MM and the VM of the hips' girth was higher than the 3.14 compared to the MM, table 3 . When observing the jacket fit to the IMP1, it is not evident that it is too wide at the locations of the breasts' and hips' girths, figure 6 . The dress pattern design was constructed according to the one body dimension, the breasts' girth, which was statistically significant. Even the MM of this body dimension was higher by $2.11 \mathrm{~cm}$ as compared to the VM, table 3 , it is not evident that the dress is too narrow in the breasts, figure 6 . For construction of the pants, none of the body dimensions had statistically significant differences between the MM and VM. In general, the results of the garments' fit to the IMP showed the suitable construction procedure and introduction of the additionally measured virtual 3D body dimensions during garments' development process using the Virtual Prototyping.

The IMP wore garments for two weeks in a real environment and performed their usual daily living activities depending on the intended use of the garments. After the wear trials the IMP1 expressed their opinions regarding the custom-made ergonomic garments (size of the adapted garment to body dimensions and sitting posture, wearing comfort during sitting and movement with a wheelchair, dressing/ undressing due to fastening solutions, appearance), which are collated briefly from written opinions in table 6.

On the basis of the subjective assessments of the tested persons on the ergonomic garments it is clear that none of them indicated that the garment was either too small or too large. This confirmed that use of new technologies in the development process of

Table 6

\begin{tabular}{|l|c|c|c|}
\hline \multicolumn{4}{|c|}{ CHEMICALS FOR DESIZING AND SETTINGS } \\
\hline \multicolumn{1}{|c|}{ Opinions } & IMP1 & IMP2 & IMP3 \\
\hline Size & 2 & 2 & 1 \\
\hline Wearing comfort & 1 & 1 & 1 \\
\hline Dressing/undressing & 1 & 2 & 2 \\
\hline Appearance & 2 & 2 & 2 \\
\hline
\end{tabular}

Note: The marks means: -2 very poor, -1 poor, 0 good, 1 very good, 2 excellent. 
the ergonomic garments' pattern designs is suitable and extremely useful for the needs of the wheelchair users' sitting posture and custom-made garments production.

\section{CONCLUSIONS}

In this study, the suitability of the 3D scanning and virtual simulation technologies in the ergonomic garments' development process was investigated for Immobile People (IMP) using a wheelchair. Based on the statistical analysis of the manual and virtual measurements of the fully mobile and immobile people, the garments fit to the tested IMP and their opinions regarding the custom-made ergonomic garments it was found that the $3 \mathrm{D}$ scanning on the developed chair prototype and virtual simulation technologies were suitable for projecting of the ergonomic garments for the wheelchair users.

Experiments have proven a synergistic effect of the new technologies during the development process of the ergonomic garments that have a great potential for their use and radical changes in the custom-made garments production for wheelchair users. Such garments, taking into account the specific demands of the ergonomic garments for a sitting posture, allow the wheelchair users an equal participation in the social environment.

Based on the gained knowledge in this study our future research will focus on the computerized processing techniques of the 3D human body mesh with automatic extraction of the scanning chair and on the pants and dress pattern making methodology for a sitting posture using a greater number of the IMP. Namely, no pattern making method has been proposed clearly on how to construct the pants and dress pattern designs for a sitting posture and the necessary minimum ease allowances for the wearing comfort, which would meet the needs of the IMP.

\section{ACKNOWLEDGEMENTS}

The authors would like to express their appreciation to persons' participation in the research.

\section{BIBLIOGRAPHY}

[1] Ng S.F., Hui C.L., Wong L.F. Development of Medical Garments and Apparel for the Elderly and the Disabled. In: Textile Progress, 2011, vol. 43, no. 4, pp. 235-285

[2] WHO World Health Organization. Health topics, Disabilities, Better health for people with disabilities: infographic, available from: http://www.who.int/topics/disabilities/en/, accessed [16. 08. 2016]

[3] Chang W.M., Zhao Y.X., Guo R.P., Wang Q., Gu X.D. Design and Study of Clothing Structure for People with Limb Disabilities. In: Journal of Fiber Bioengineering and Informatics, 2009, vol. 2, no. 2, pp. 61-66

[4] Chang H.J.J., Hodges N., Yurchisin J. Consumers With Disabilities: A Qualitative Exploration of Clothing Selection and Use Among Female College Students. In: Clothing and Textiles Research Journal, 2014, vol. 32, no. 1, pp. 34-48

[5] Thoren M. Systems approach to clothing for disabled users. Why is it difficult for disabled users to find suitable clothing. In: Applied Ergonomics, vol. 27, no. 6, pp. 389-396

[6] Lamb J.M. Disability and the Social Importance of Appearance. In: Clothing and Textiles Research Journal, 2001, vol. 19, no. 3, pp. 134-143

[7] Aromaa S., Väänänen K. Suitability of virtual prototypes to support human factors/ergonomics evaluation during the design. In: Applied Ergonomics, 2016, vol. 56 (September), pp. 11-18

[8] Wang G.G. Definitions and review of virtual prototyping. In: Journal of Computing and Information Science in Engineering (Transactions of the ASME), 2003, vol. 2, no. 3, pp. 232-236

[9] Aileni R.M., Ciocoiu M., Fărîmă D. Modeling and 3D simulation of the garment product. In: Industria Textila, 2011, vol. 62, no. 3, pp. 141-145

[10] Ancutiene K. Comparative analysis of real and virtual garment fit. In: Industria Textila, 2014, vol. 65, no. 3, pp. 158-165

[11] ISO 8559:1989 Garment construction and anthropometric surveys - Body dimensions, 1989

[12] D'Apuzzo N. 3D body scanning technology for fashion and apparel industry. In: Videometrics IX, Proceedings of SPIE-IS\&T Electronic Imaging, SPIE, vol. 6491, San Jose (CA), USA, 2007, p. 12

[13] Stjepanović Z., Rudolf A., Jevšnik S., Cupar A., Pogačar V., Geršak J. 3D virtual prototyping of a ski jumpsuit based on a reconstructed body scan model. In: Buletinul Institutului Politehnic din laşi. Secția Textile, 2011, Pielărie 1, pp. $17-30$

[14] Jevšnik S., Pilar T., Stjepanović Z., Rudolf A., Virtual prototyping of garments and their fit to the body. In: DAAAM International scientific book 2012. Vienna: DAAAM International Publishing, 2012, pp. 601-618

[15] Jevšnik S., Stjepanović Z., Rudolf A., Grujić D., Pilar T. Assessing garments fit to woman's body. In: ACC Journal. Issue A, Natural sciences and technology, 2014, vol. 20, no. 1, pp. 28-37 
[16] Stjepanović Z., Cupar A., Jevšnik S., Kocjan-Stjepanović T., Rudolf A. Construction of adapted garments for people with scoliosis using virtual prototyping and CASP method. In: Industria Textila, 2016, vol. 67, no. 2, pp. 141-148

[17] Rudolf A., Kozar T., Jevšnik S., Cupar A., Drstvenšek I., Stjepanović Z. Research on 3D body model in a sitting position obtained with different 3D scanners. In: Proceedings of The International Istanbul Textile Congress 2013, Istanbul, Turkey, May-June 2013, pp. 263-269

[18] Rudolf A., Stjepanović Z., Jevšnik S., Cupar A. Research on the applicability of CASP methodology for nonstandard body shapes' garment pattern design. In: Proceedings, 16th World Textile Conference AUTEX 2016, Ljubljana, Slovenia. 8-10 June 2016, (CD version), pp. 1-7

[19] Rudolf A., Cupar A., Kozar T., Stjepanović, Z. Study regarding the virtual prototyping of garments for paraplegics. In: Fibers and Polymers, 2015, vol. 16, no. 5, pp. 1177-1192

[20] Goswami A., Ganguli S., Chatterjee B.B. Anthropometric characteristics of disabled and normal Indian men. In: Ergonomics, 1987, vol. 30, no. 5, pp. 817-823

[21] Das B., Kozey J. W. Structural anthropometric measurements for wheelchair mobile adults. In: Applied Ergonomics, 1999, vol. 30, no. 5, pp. 385-390

[22] Lucero-Duarte K., de la Vega-Bustillos E., López-Millán F. Soto-Félix S. Anthropometric data of adult wheelchair users for Mexican population. In: Work, 2012, vol. 41 (supplement 1), pp. 5408-5410

[23] Wang Y., Wu D., Zhao M., Li J. Evaluation on an ergonomic design of functional clothing for wheelchair users. In: Applied Ergonomics, 2014, vol. 45, no. 3, pp. 550-555

[24] Pruthi N., Seetharaman P., Chanchal. Clothing Related Problems Encountered by Paraplegics. In: Journal of Human Ecology, 2005, vol. 17, no. 1, pp. 59-61

[25] PruthiN., Chanchal, Sutharamn P. Protective Clothing for Paraplegic Women. In: Journal of Human Ecology, 2006, vol. 19 , no. 4 , pp. $267-271$

[26] Pruthi N., Chanchal, Sutharamn P. Protective Clothing for Paraplegic Men. In: Journal of Human Ecology, 2006, vol. 20, no. 2, pp. 103-108

[27] Curteza A., Cretu V., Macovei L., Poboroniuc M. Designing Functional Clothes for Persons with Locomotor Disabilities. In: Autex Research Journal, 2014. vol. 14, no. 4, pp. 281-289

Authors:
ANDREJA RUDOLF
LUCIE GÖRLICHOVÁ
JERNEJ KIRBIŠ
JASNA REPNIK
ANDREJ SALOBIR
IRMA SELIMOVIĆ
IGOR DRSTVENŠEK
University of Maribor
Faculty of Mechanical Engineering
Smetanova 17, 2000 Maribor, Slovenia
e-mail: andreja.rudolf@um.si, luciegorlichova@gmail.com, jernejkirbisss@gmail.com, jasna.repnik@gmail.com,
andrej.salobir@gmail.com, irma.selimovich@gmail.com, igor.drstvensek@um.si
Corresponding author:
ANDREJA RUDOLF
andreja.rudolf@um.si




\section{Innovative technologies for the design and simulation of children's clothing products using anthropometric data obtained by 3D standardized scanning}

\section{REZUMAT - ABSTRACT}

\section{Tehnologii inovative de proiectare şi simulare a produselor vestimentare pentru copii utilizând}

date antropometrice obţinute prin scanare 3D standardizată

Lucrarea prezintă etapele proiectării unor produse vestimentare pentru copii având la bază noile date antropometrice obținute prin scanare 3D din standardul antropometric elaborat de INCDTP. Tehnologia de proiectare este inovativă şi permite realizarea tiparelor pentru toate grupele de vârstă ale copiilor, utilizând un singur tipar de bază al unui tip de produs vestimentar. Numărul mare de date antropometrice 3D existente în standard permite includerea acestora în algoritmii de proiectare, parametrizarea manechinului virtual, simularea $3 D$, verificarea corespondenței corp-produs, modificarea automată a tiparelor până la îndeplinirea gradului de conformitate al produsuuil proiectat. În cadrul lucrării se prezintă metodologia de simulare $3 D$ a produselor vestimentare reprezentative destinate copiilor.

Cuvinte-cheie: îmbrăcăminte copii, tipare, simulare $3 D$, standard antropometric

Innovative technologies for the design and simulation of children's clothing products using anthropometric data obtained by 3D standardized scanning

The paper presents the design stages of children's clothing products and is based on new anthropometric data obtained by $3 D$ scanning of anthropometric standard developed by INCDTP. The design technology is innovative, enabling the development of patterns for all age groups of children, using a single basic pattern of a type of clothing product. The large number of existing 3D standard anthropometric data allows their inclusion in the design algorithms, parameterization of the virtual dummy, 3D simulation, verification of body-product correspondence, automatic change of patterns until the fulfilment of compliance for the product designed. The paper presents the $3 D$ simulation methodology of representative clothing products for children.

Keywords: children's clothing, patterns, 3D simulation, anthropometric standard

\section{INTRODUCTION}

With the development of technologies and change of lifestyle thereby, the rhythm and intensity of parenting, the specific needs and demands of modern life have also changed. The growing stature is required to be analyzed in terms of the modifications of certain body segments (head, thorax, limbs). Weight gain is the increase in mass with increasing body height and after the completion of stature growth, further body mass increase is due to fat deposits, respectively the modifications in the transverse direction of the body [1-2]. Therefore, new research on information relating to the exterior shape of the human body during childhood is required, namely conformation, outfit, proportions, indicators that are closely related to the quality of clothing products. Sizing of patterns in industrial design of children's clothing products is based on type body systems, specific to age groups, gender of wearer and particular proportions between different body sizes. The patterns designed for a specific size are then graded for all sizes. Using complex CAD/CAM systems, in which there are embedded automation subsystems of construction of basic patterns, model patterns and patterns are obtained by replacing standardized data in computer software patterns of a model for all typodimensions by eliminating the grading operation.

\section{EXPERIMENTAL WORK}

\section{Analysis of anthropometric data obtained by 3D} scanning

Children's clothing product development is based on anthropometric data found in SR 13546/2012 developed by the National Research and Development Institute for Textiles and Leather. This includes dimensional characteristics taken by 3D body scanning of Romanian children, by age groups. Of 150 measurements resulted from 3D body scanning, 44 dimensional characteristics that provide information needed for clothing designers and pattern makers for sizing patterns and clothing were selected.

The main size for size designation of children's clothing is body height. This choice corresponds with European standards for children's clothing size designation, thus achieving harmonization.

The standardized heights of Romanian children aged 6-19 years are:

- girls: $110 ; 116 ; 122 ; 128 ; 134 ; 140 ; 146 ; 152 ; 158$; 164; $170 ; 176 \mathrm{~cm}$; 
- boys: $110 ; 116 ; 122 ; 128 ; 134 ; 140 ; 146 ; 152 ; 158$; $164 ; 170 ; 176 ; 182 ; 188 \mathrm{~cm}$.

Interdimensional range value for the main dimension, body height is $6 \mathrm{~cm}$. The secondary standardized dimensions of the body corresponding to each height as main size were calculated statistically.

Thus, having a complex antropo-morphological data base which gives the pattern designer a vision closer to reality of the body studied, the development of the clothing product can be achieved with CAD (Computer Aided Design) technology. This technology provides the specialist the opportunity to design, simulate and model the clothing on virtual dummies, thus obtaining a dimensional correspondence bodyproduct and a faithful fit of the product on the body in little time and with minimal costs compared to the traditional pattern design technology.

\section{Design of basic patterns for children's clothing products}

To design the basic patterns the following are necessary:

- specific body dimensions (bust circumference, waist circumference, etc.);

- specific product dimensions (hem width, product length, etc.) which are established depending on the product destination and the fashion factor;

- additions that ensure the correspondence between the body shape and dimensions with those of the product and its type and destination.

Clothing products fall into two broad categories according to the data needed for the construction of patterns: shoulders support products and waist support products.

The algorithm of pattern construction translated into mathematical language underlies the foundation of automated design systems. Graphic, conventional construction of patterns starts from an initial axis system and from a network of base lines, in which the contour lines of the patterns are drawn [3]. Relationships currently used are usually established empirically and reflect the author's personal way of expressing the proportionality that exists between different parts of the body. The multitude of calculation relations used in the sizing of the constructive segments was classified into three main types. The type of relations, which are operated by an author, is a prime criterion for evaluating the precision offered by a certain constructive solution. Table 1 shows the classification of relationships used in sizing patterns. The criteria for assessing the accuracy provided by the geometric method applied in the construction of patterns for a given type of product are:

- the quality of initial information on the sizes and shape of the wearer's body;

- means of determining the various categories of additions and their distribution by constructive segments;

- initial axis position and correctness of graphics solutions used in drawing the contour lines of patterns, based on the laws of plane geometry.

Using a large number of information about the body of the future wearer is a condition to ensure dimensional correspondence body-clothing product. Using 3D scanner VITUS Smart XXI there will be obtained a variety of anthropometric data which are primary data in pattern design algorithms. This results in a simplification of the calculation of design algorithms and optimum correspondence of the product on the body.

With the development of complex CAD/CAM systems, in which there are embedded automation subsystems of the construction of basic patterns, model patterns and patterns, the novelty will consist of the fact that the model patterns for all typodimensions

\begin{tabular}{|c|c|c|c|}
\hline Type & Relation & Term significance & Example of relation \\
\hline 1 & $Y=X+A$ & $\begin{array}{l}X=\text { an anthropometric size which determines directly } \\
\quad \text { the pattern segment; } \\
A=\text { total addition }\end{array}$ & $\begin{array}{l}1141=\mathrm{Lt}+\text { Alt } \\
3133=\text { Is }+ \text { Als }\end{array}$ \\
\hline II & $Y=a X^{\prime}+b A+c$ & $\begin{array}{l}X^{\prime}=\text { an anthropometric size that does not directly } \\
\text { determine the respective pattern segment; } \\
A=\text { total addition that will be assigned on } Y \text { segment; } \\
\text { a, b, c = proportionality coefficients expressing the } \\
\text { relationship between the constructive } \\
\text { segment and } X \text { body size' }\end{array}$ & $\begin{array}{l}1141=\mathrm{Ic} / 4+1 \\
31-33=(0,18 \mathrm{~Pb}+0,5)+0,25 \mathrm{Ab}\end{array}$ \\
\hline III & $Y=a Y^{\prime}+b$ & $\begin{array}{l}Y^{\prime}=\text { a segment of the previously calculated or } \\
\text { graphically obtained pattern } \\
a, b=\text { coefficients expressing the relationship } \\
\text { between the two segments of the } Y \text { and } Y^{\prime} \text { pattern }\end{array}$ & $\begin{array}{l}1737=1131+4 \\
12121=0,3(1112) \\
\mathrm{Icm}=\operatorname{lrm}-\mathrm{C}\end{array}$ \\
\hline
\end{tabular}

\section{Where:}

Lt - length of the back from the cervical point to the waist; Alt - addition of looseness for the length of the back to the waist; Is - height of the back from the cervical point to the armpit; Als - addition of looseness for the height of the back; Ic - body height; Pb - bust perimeter; Ab - addition of looseness in the bust area; Icm - height of the sleeve head; Irm - width of the sleeve cut. 
will be obtained by direct construction (by modifying the initial data in computer software) and thus to eliminate the grading operation.

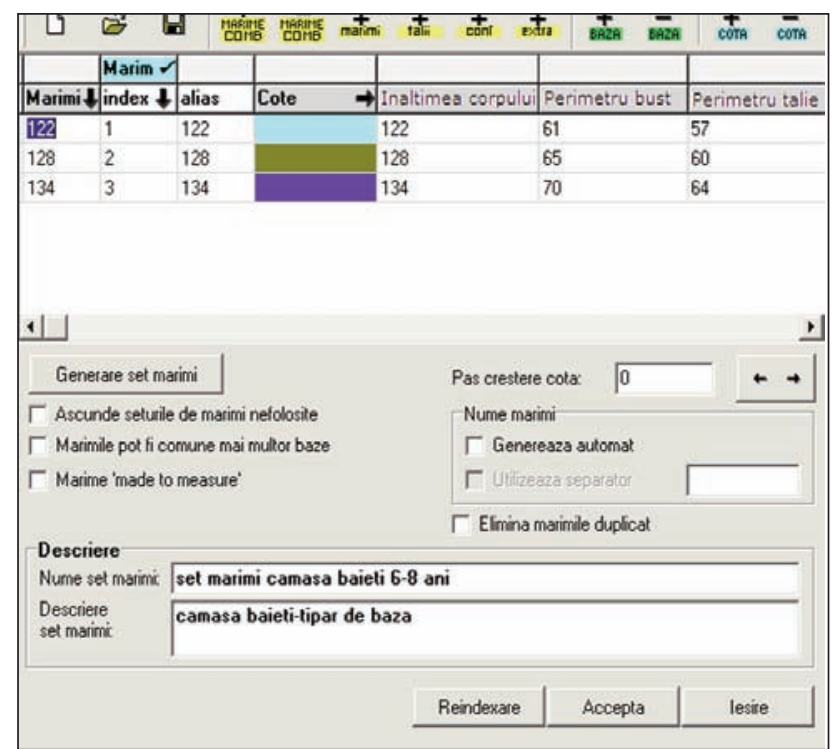

Fig. 1. Shirt design data introduced into the Software
Design of the basic patterns for children was made using Made-to-Measure (MTM) module of GeminiCAD system. The stages of designing the basic patterns for children's clothing products are the following [4]:

1. Defining the set of anthropometric sizes for the type of product and age group for which the product is designed in the size table of the software (figure 1); 2. The Table is filled in with anthropometric sizes corresponding to the anthropometric standard and the values of the additions of looseness set depending on the product category;

3. The table is saved specifying the category of age and product; this step will be followed also for all groups of age and categories of product.

4. The basic network for a minimum set established will be designed, using the design algorithms specific to the category of product;

5. There will be extracted the contours of the designed patterns and their final form will be finalized (figure 2, figure 3).

To obtain the basic pattern for the same category of product, but for a different category of age, the set of sizes for the new category of age will be introduced into the table of sizes (e.g. 9-11 years old).

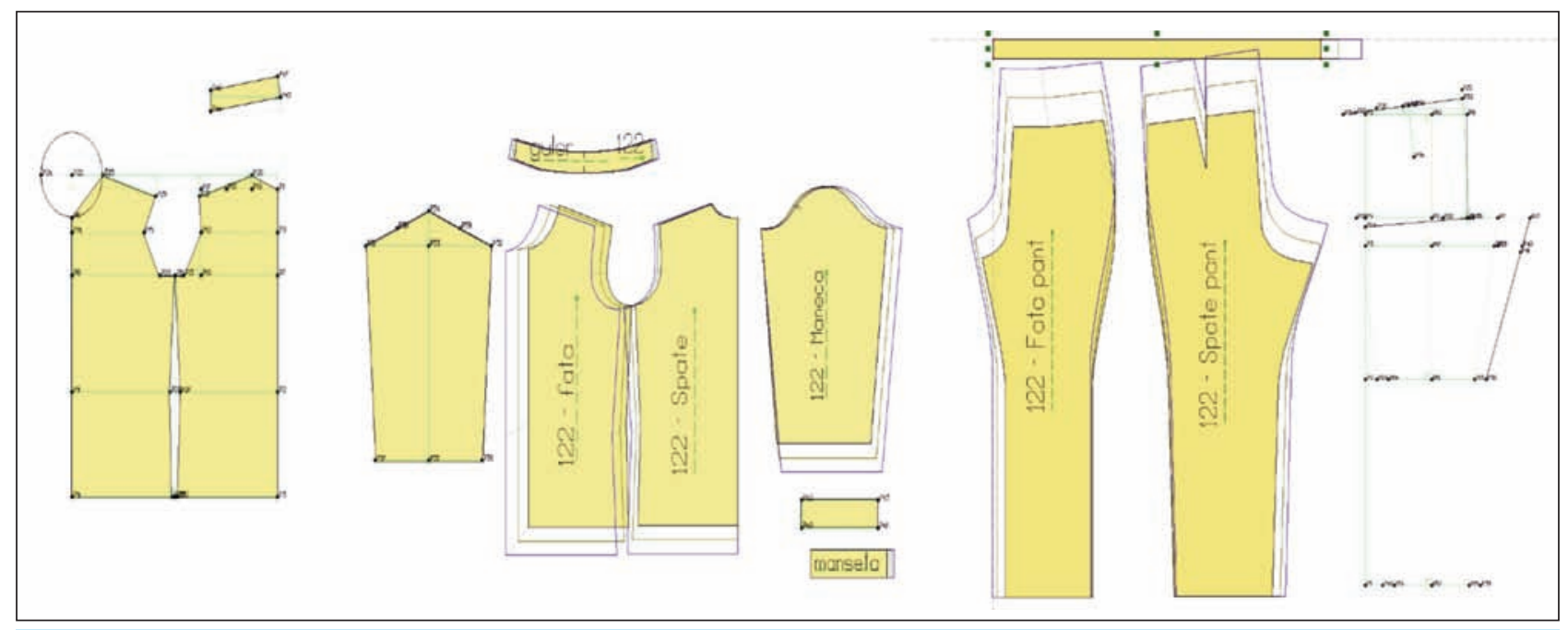

Fig. 2. Design of the basic patterns for boys' shirt and trousers in MTM module

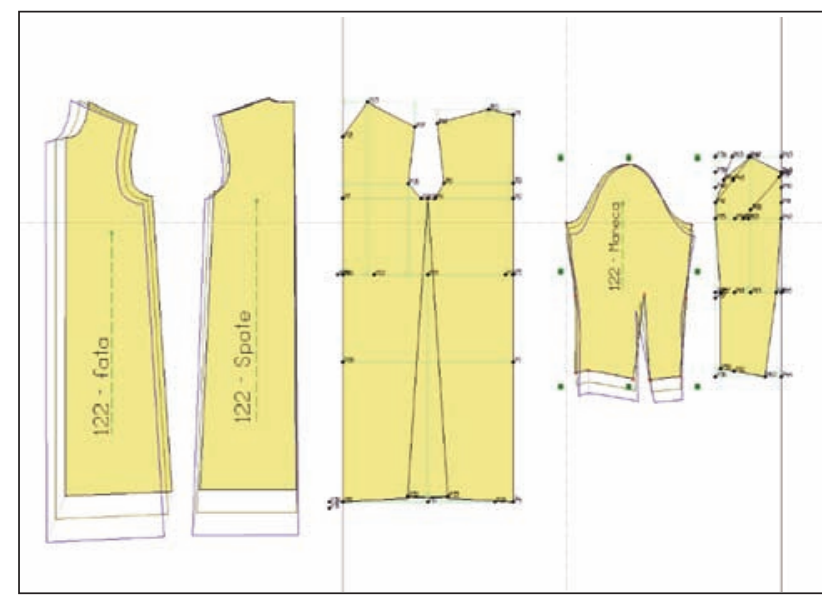

Fig. 3. Design of the basic patterns for girls' dress in MTM module

\section{RESULTS AND DISCUSSIONS}

3D simulation of clothing products on virtual dummy adapted to the real dimensions

Transposition of flat patterns to $2 \mathrm{D}$ clothing products made with different 3D CAD systems (Lectra, Gemini, Investronica, Gerber, Optitex) is a laborious activity that requires knowledge of the following aspects [5]:

- information on the materials from which the clothing products are made (fiber composition, draper, shrinkage, weight, etc.);

- geometry of the body area on which the part/ product is placed;

- product manufacturing technology;

- possibilities of changing the patterns according to the body shape and material characteristics. 


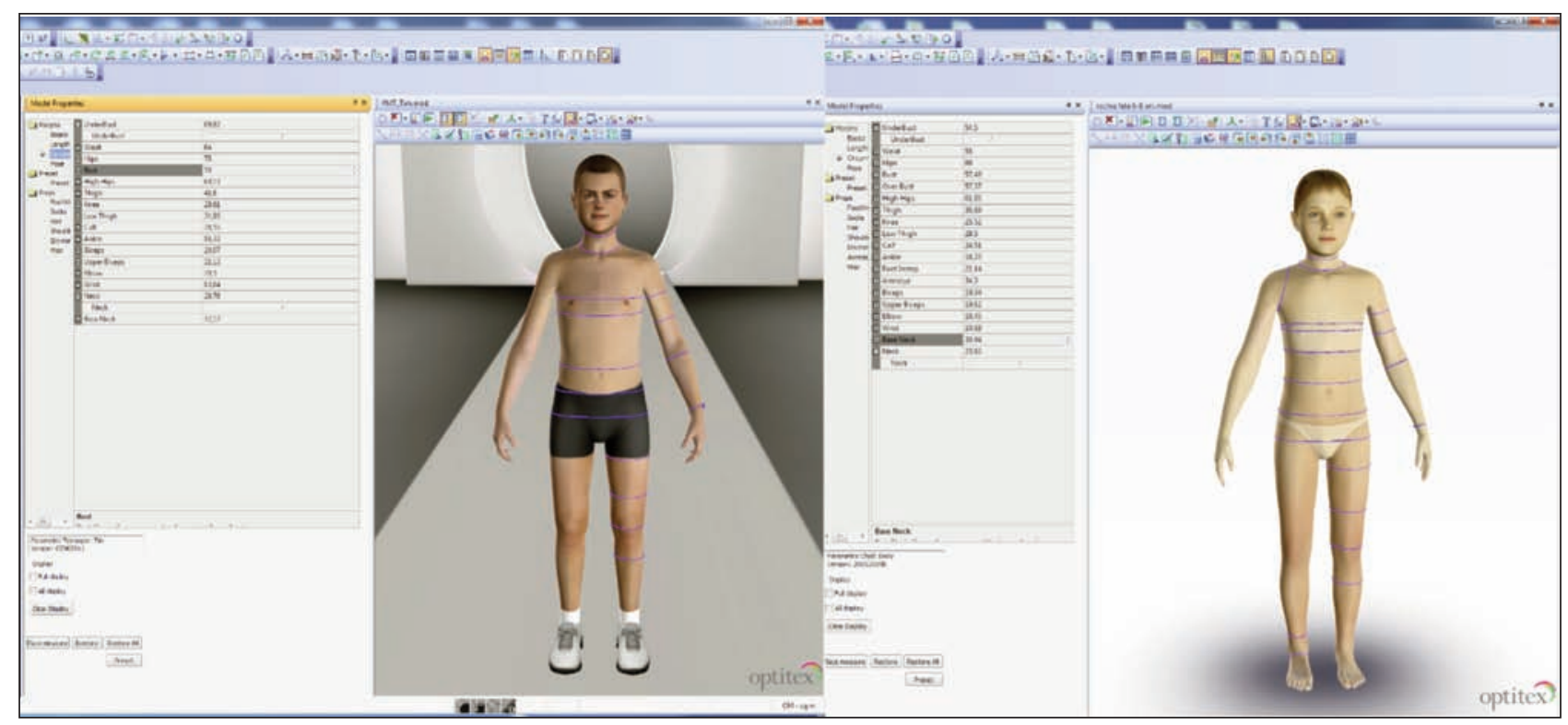

Fig. 4. Parameterization of dummies for boys and girls

The novelty lies in checking the correspondence body-product of 2D clothing products through simulation and virtual modelling in 3D OPTITEX PDS system on virtual dummy parameterized in the following steps:

- Step 1. Import of basic patterns made in MTM Gemini Cad Systems work module, in the specialized software for simulation of correspondence body-product, 3D OPTITEX PDS;

- Step 2. Application of directions for assembling the parts;

- Step 3. Preparing the dummy. This involves parameterization of the dummy according to the sizes and shape of the body specific to the conformational type

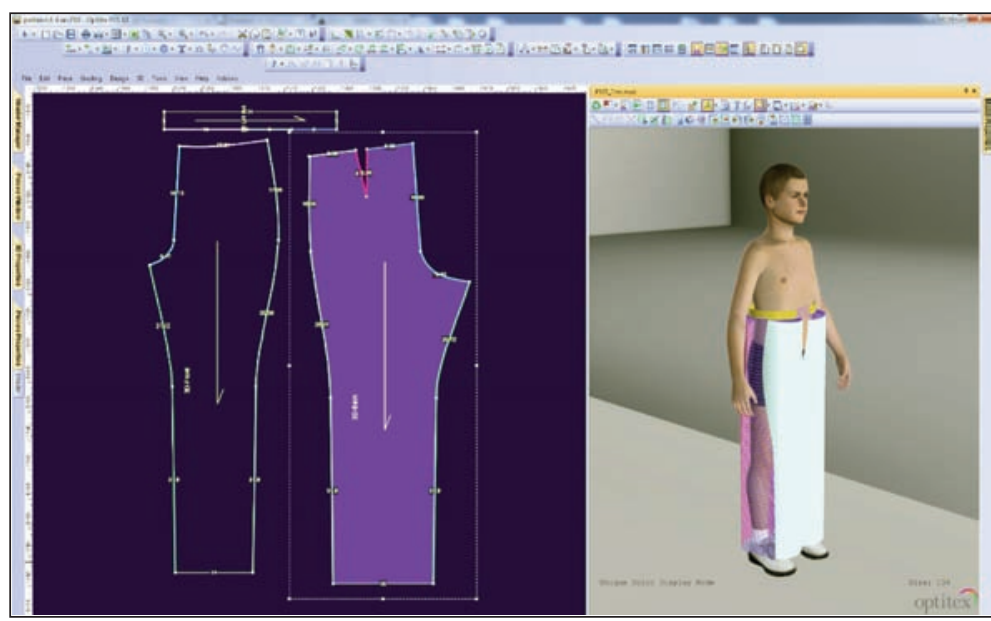

Fig. 5. Drawing the sewing lines and placing the patterns on the dummy for which the design algorithm of the

basic pattern was customized. Thus, the corresponding values of the anthropometric sizes of anthropometric standard Clothing. Body dimensions for children between 6 and 19 years old will be inserted in the table "Model properties". Figure 4 shows the virtual bodies parameterized for age group 6-8 years old for boys and girls, respectively.

- Step 4. Placing the patterns on the parameterized dummy. To perform the assembly simulation, the patterns must be placed from the PDS work area to the 3D work area of PDS software. In this respect click the button "Place cloth" (figure 5).

- Step 5. Processing the simulation stage. Once correctly performed the assembling of the parts, it can begin the processing of the simulation stage. This phase starts with clicking the button "Simulate". The duration of the simulation process varies depending on the number of parts placed in 3D simulation window, the complexity of the simulated model and the number of stitches.
For example, to simulate the product "shirts for boys", the patterns were placed according to its placement on the body, namely the front sides, the back, sleeves, collar and cuffs and its simulation on the dummy was processed (figure 6).

It was proceeded in the same way for the simulation of the product "trousers for boys" (figure 7) and "dress for girls" (figure 8).

- Step 6. Checking the correspondence body-product. 3D OPTITEX PDS provides various possibilities to check the proper correspondence between the body and the simulated product, one of them being the use of the tension map. The visualization of the tension map shows the user the essential aspects of the distance from the body of the product and the level of comfort offered by the product to the body on which it was simulated. This comfort is visualized by displaying on the virtual dummy of areas in 3 different colours: red, green and blue. Each colour has a very important meaning (red indicates high pressure of 


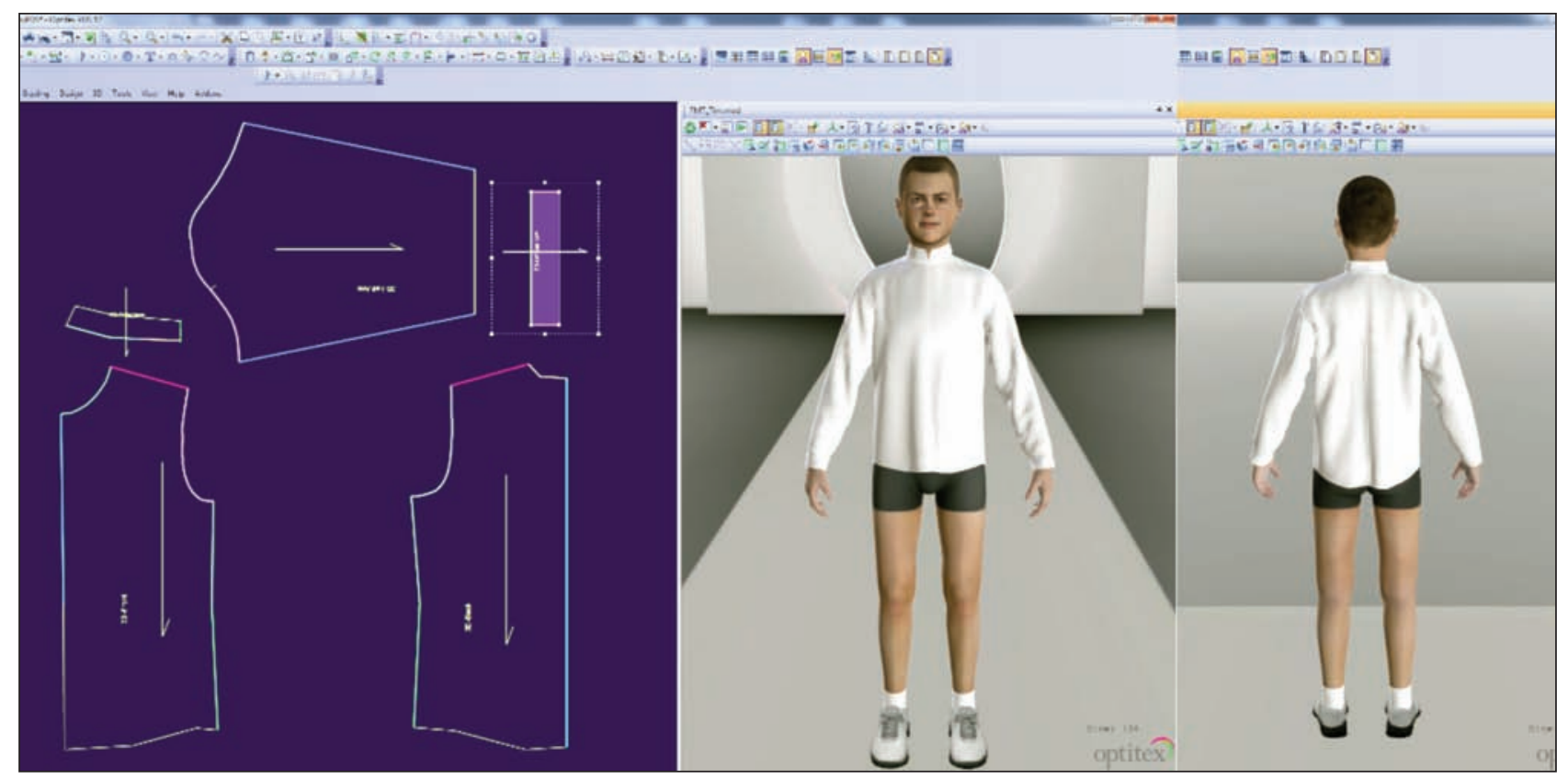

Fig. 6. Front and back view of the product "shirt for boys"

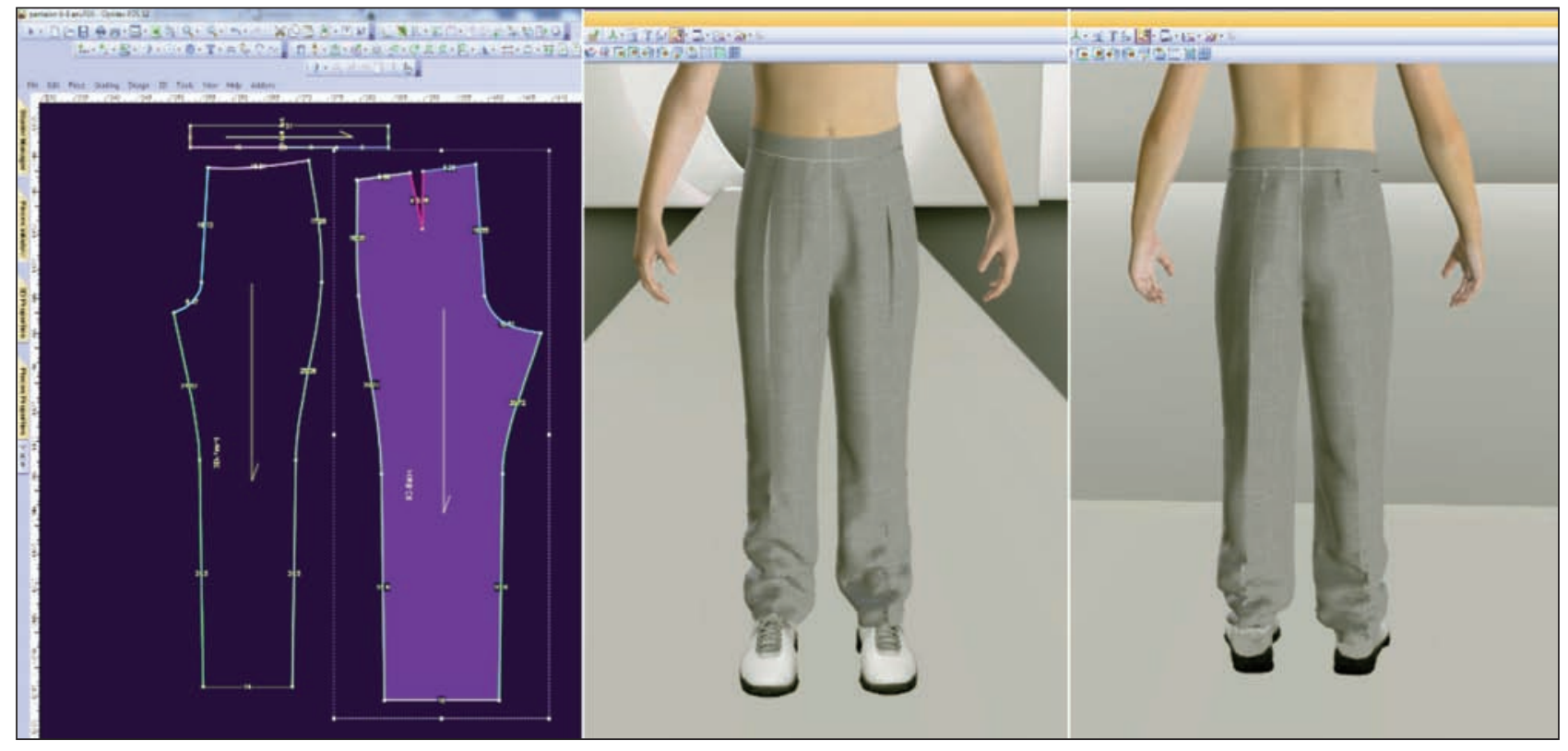

Fig. 7. Front view and back view of the product "trousers for boys"

the product on the body, green indicates an optimal closeness to the body and blue indicates a great looseness of the product) which allows the designer to observe where the pattern does not match the body conformation and what adjustments are necessary to remedy the situation.

It was visualized the degree of adjustment on the body of the product "shirt for boys", with the function "Tension Map". It can be observed the support area of the product (shoulders area) marked in red, a greater closeness to the body in the chest area and termination of the sleeves by adjusting them using cuffs, which is marked in green and a great looseness in the area marked in blue (figure 9).
Using the same function "Tension Map", it was visualized then the degree of adjustment to the body for the product "trousers for boys". It can be observed the support area of the product (waist) which is marked in red, greater closeness to the body in the hip area marked in green and a great looseness in the other areas marked in blue colour (figure 10 and figure 11).

The visualization of the degree of adjustment to the body of the product "dress for girls", indicates a greater closeness to the body in the support area of the product (shoulders) marked in red, an average closeness to the body in the area marked in green and a great looseness in the other areas marked in blue colour. 


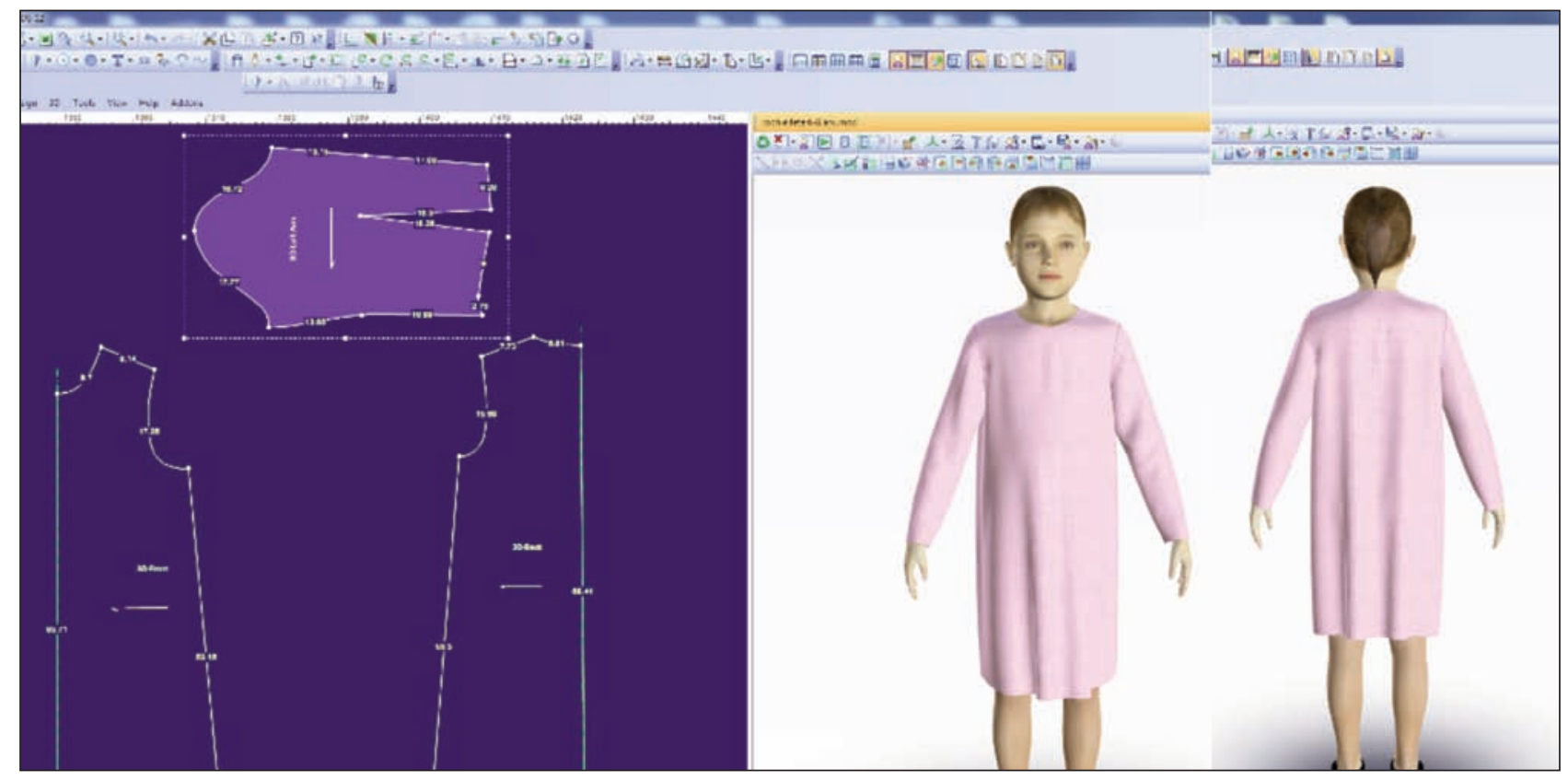

Fig. 8. Front view and back view of the product "dress for girls"

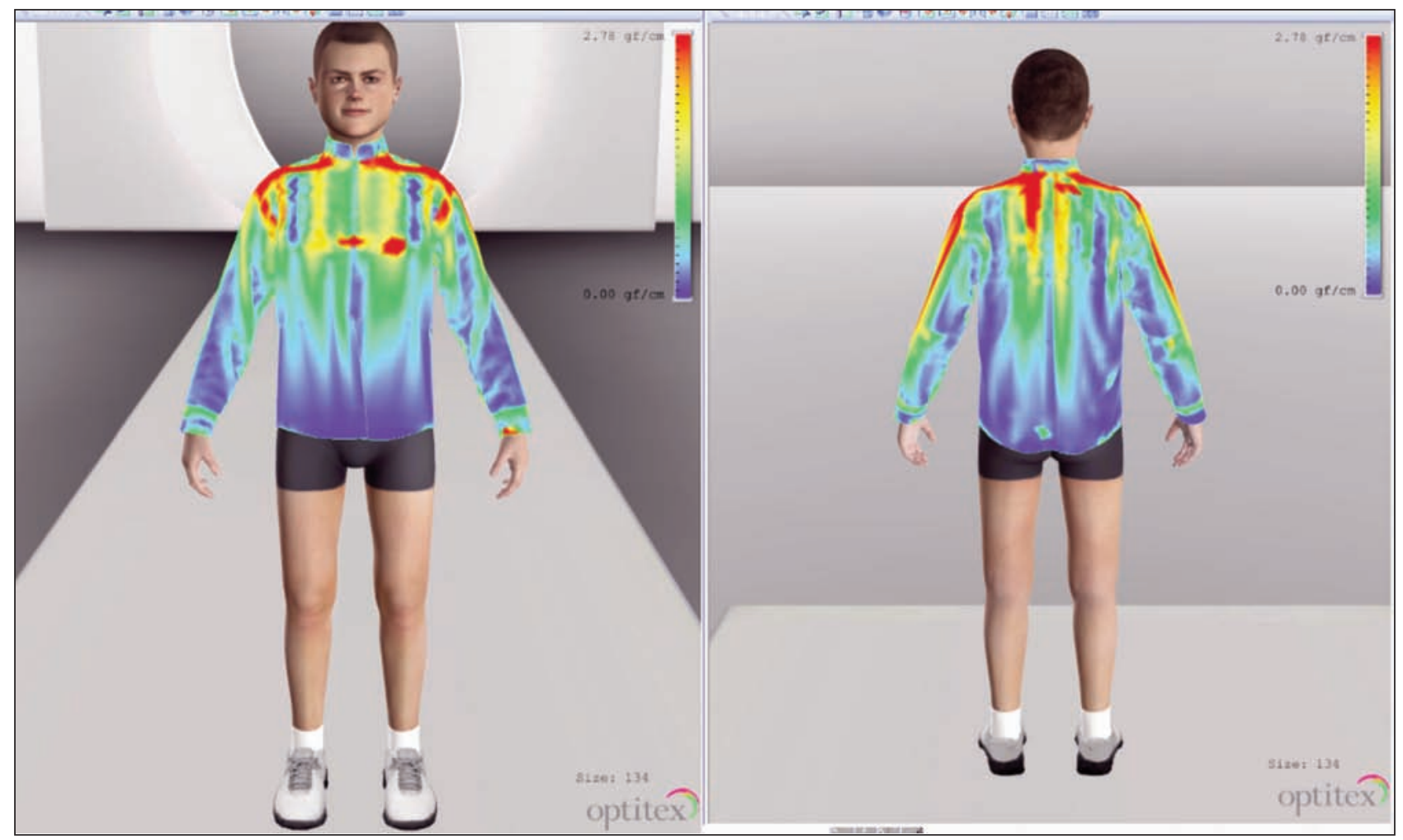

Fig. 9. Tension map for the product "shirt for boys"

Checking the patterns made in accordance with 3D anthropometric data by parameterized dummy simulation indicates an adequate fit of the products on the body, both from a dimensional point of view and in terms of their stability on the support area.

\section{CONCLUSIONS}

The paper presents a new method of designing the basic patterns for clothing products for children of different age groups (6-8 years, 9-11 years and 12-13 years old) using anthropometric measurements taken by 3D scanning and the technique of checking the dimensional correspondence body - product by product modelling and simulation on the virtual dummy.

Application of research results will allow the makers and designers of clothing items for children to design products perfectly adapted to their standard sizes as follows: 


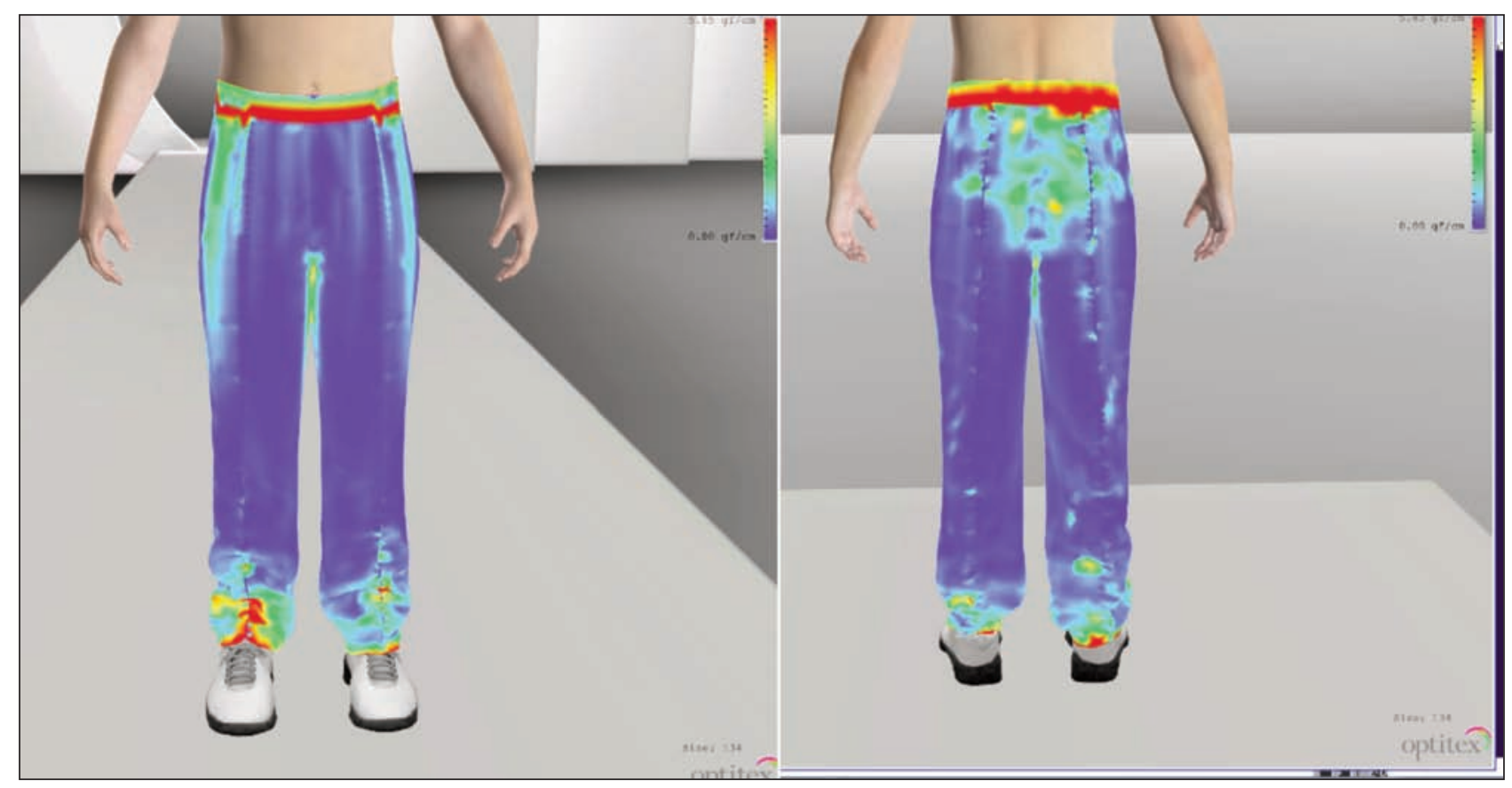

Fig. 10. Tension map for the product "trousers for boys"

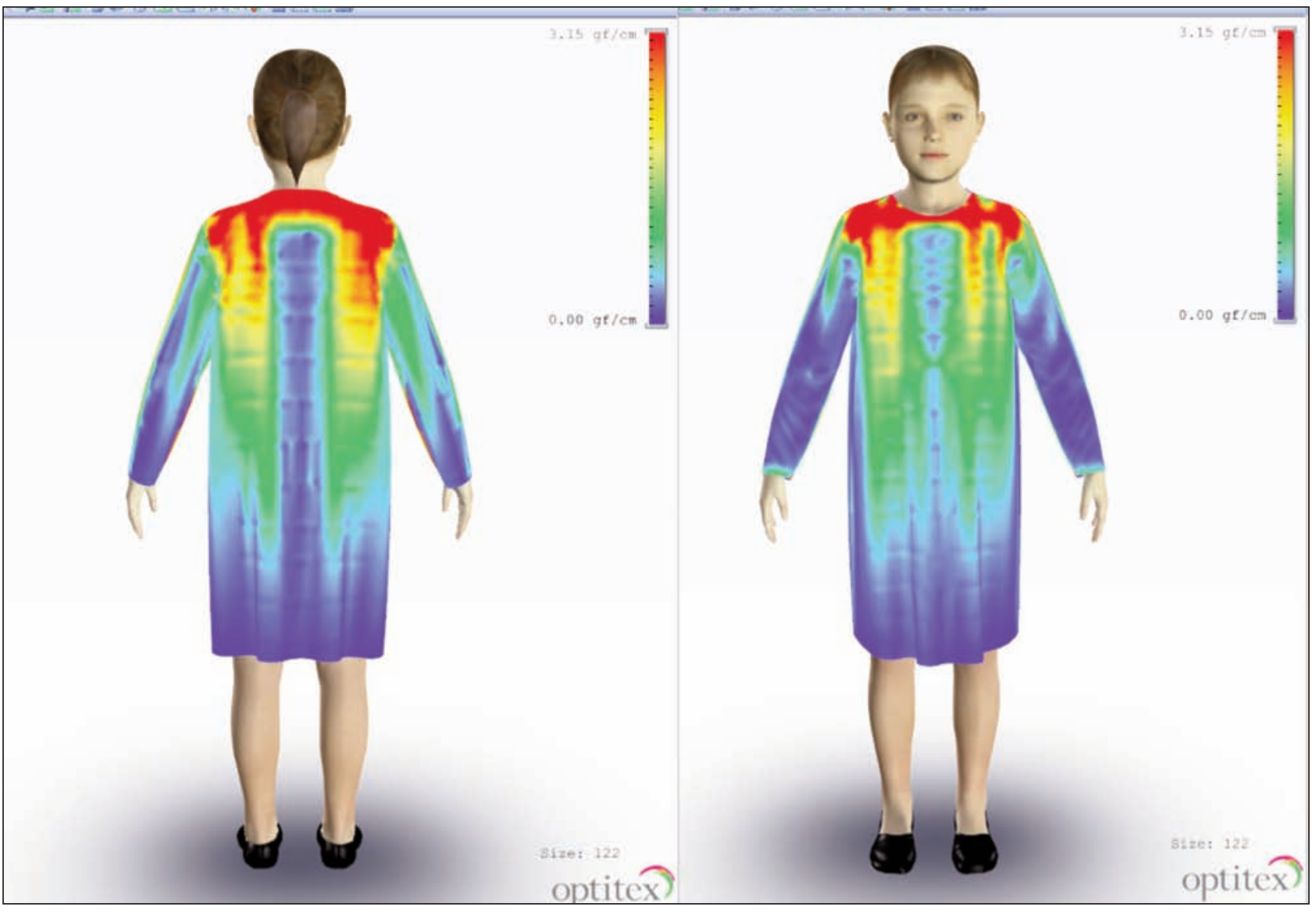

Fig. 11. Tension map for the product "dress for girls"

1. The use of parameters for general characterization of the shape and constructive characteristics of the clothing products for children depending on age category and the destination and the type of product; 2. The use of the necessary 3D anthropometric dimensions and the additions to the development of the design algorithms. The main anthropometric dimension for the determination of the clothing size for children is the body height, the other necessary dimensions being selected from the standard depending on it; 
3. The use of the new design method of basic patterns according to several 3D anthropometric dimensions, existing in the standard compared with anthropometric dimensions required by the design software used, which will lead to the development of very precise patterns in a reduced time;

4. The use of 3D Optitex PDS modelling-simulation software of 2D patterns on parameterized dummies to anthropometric measurements for which the clothing products were designed and the visualization of correspondence body-product on the tension map.

\section{ACKNOWLEDGEMENTS}

This paper was elaborated as part of the Nucleu Program, executed with the support of ANCSI, project no. PN 16340501.

\section{BIBLIOGRAPHY}

[1] *** Standard SR 13546/2012, Confecții. Dimensiunile corpului pentru copii cu vârsta cuprinsă între 6 şi 19 ani

[2] Niculescu Claudia, Olaru Sabina, Salistean Adrian, Anthropometric parametres of children in Romania, result of the anthropometric survey carried out in 2010-2011, In: Industria Textila, 2012, vol. 63, issue 4, pp. 176-182

[3] Asociația Generală a Inginerilor din Romania, Societatea Inginerilor Textilişti din Romania (S.I.T. - A.G.I.R.), Secțiunea VII - Confecții textile, Proiectarea constructivă a produselor de îmbrăcăminte, In: Manualul inginerului textilist, 2003, vol. II, Editura AGIR

[4] Pintilie Ecaterina, Ciubotaru Gabriela, Avădanei Manuela, Proiectarea confecțiilor textile asistate de calculator, 2006, Ed. Performantica, Iaşi, ISBN 973 -730-259-1

[5] Emilia Filipescu, Sabina Olaru, Elena Filipescu, Eco-design al îmbrăcămintei prin simularea în spațiu virtual a sistemului corp-îmbrăcăminte, In: Buletinul AGIR. 2012, issue 2, pp. 153-159
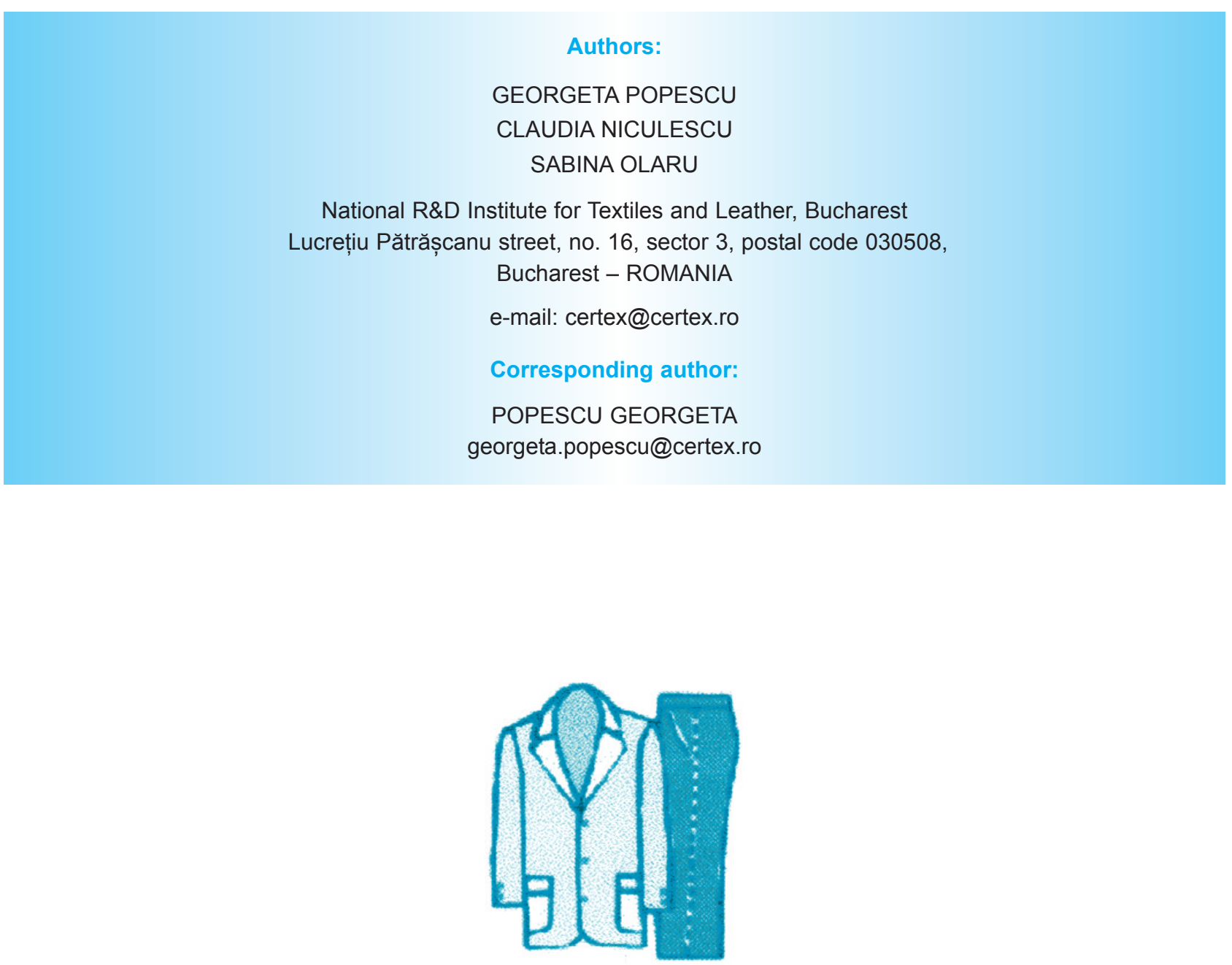


\section{Investigation of dyeing methods on wool fabrics with hibiscus and its antibacterial efficiency}

DOI: 10.35530/IT.068.02.1288

\section{REZUMAT - ABSTRACT}

Investigarea metodelor de vopsire a țesăturilor din lână cu hibiscus și eficiența antibacteriană a acestora

Lucrarea prezintă utilizarea coloranților naturali sub formă de pudră, extrași din flori și frunze de Hibiscus, pentru vopsirea țesăturilor din 100\% lână. În acest scop, au fost utilizați doi mordanți (sulfat de cupru $\mathrm{CuSO}_{4} \cdot 5 \mathrm{H}_{2} \mathrm{O}_{\text {și clorură }}$ de staniu (II) $\mathrm{SnCl}_{2}$ ) și metodele de aplicare (pre-, meta-, post-mordansare), iar efectele acestora asupra capacității de vopsire, proprietățile de rezistență a culorii și caracteristicile antibacteriene ale țesăturii de lână vopsite cu mordanți au fost investigate și evaluate. Rezistența culorii în ceea ce privește spălarea și rezistența la frecare a fost destul de bună pentru ambii reactivi mordanți. Chiar dacă sulfatul de cupru nu a demonstrat eficiență antibacteriană, proprietăți antibacteriene sporite au fost obținute folosind clorura de staniu ca reactiv mordant.

Cuvınte-cheie: hibiscus, clorură de staniu II, antibacterian, mordansare, vopsire

\section{Investigation of dyeing methods on wool fabrics with hibiscus and its antibacterial efficiency}

The present paper deals with the application of natural dyes extracted from powdered Hibiscus flowers and leaves on $100 \%$ woolen fabric. For this puposes, two mordants (copper sulphate, $\mathrm{CuSO}_{4} .5 \mathrm{H}_{2} \mathrm{O}$ and tin (II) chloride, $\mathrm{SnCl} \mathrm{C}_{2}$ and the application methods (pre-, meta-, post- mordanting) were used and their effects on dyeability, color characteristics, fastness properties and antibacterial activities of dyed-mordanting woolen fabric were investigated and evaluated. The color fastness with respect to washing and rubbing was quite satisfactory for both mordant reagents. Unless cupper sulphate was not shown antibacterial efficiency, high antibacterial activity was obtained using tin chloride as a ordant reagent.

Keywords: hibiscus, tin-Il-chloride, antibacterial, mordanting, dyeing

\section{INTRODUCTION}

Textile dyeing has been in practice since ancient times. In the early age, plants and animals resources were used to dye textiles. People used natural dyes for colouring rugs, carpets and clothing by using various parts of plants. Hibiscus, which has been used for dyeing textiles, belongs to the family of Malvaceae [1]. Chemical structure and the main components of Hibiscus are given in table 1 and 2. The main components of Hibiscus are anthocyans, organic acids and carbohydrates [2].

\section{Anthocyans}

These compounds are directly related to flavonoids, which can be found as free aglycons (anthocyanidins). They are coloured compounds, their colour varying with the $\mathrm{pH}$. Anthocyans (Delphinidin ${ }^{1}$, Cyanidin $^{2}$ ) may reach up to $2 \%$ concentration.

1. Delphinidin<smiles></smiles>

Table 1

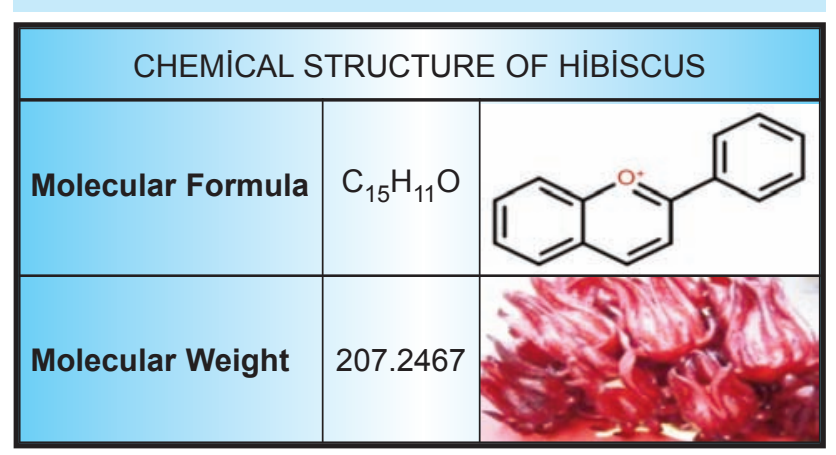

Table 2

THE MAIN COMPONENTS OF HIBISCUS

\begin{tabular}{|l|l|}
\hline Structure & Components \\
\hline Anthocyans & Delphinidin, cyanidin \\
\hline Organıc acıds & Oxalic, tartaric, malic, succinic, hibiscic \\
\hline Carbohydrates & $\begin{array}{l}\text { Simple sugars, oligosaccharides, } \\
\text { mucilages }\end{array}$ \\
\hline
\end{tabular}

Organic acids

Hibiscus contains a high organic acids percentage (15-30\%), oxalic acid, tartaric acid, malic acid, succininc acid and hibiscic acid among them. Oxalic and 
tartaric acids constitute more than three quarters of the total acids present in hibiscus.

Carbohydrates

The plant as a whole is rich in carbohydrates $(9.2-76.5 \%)$. However, the carbohydrate percentage reduces to about $3.3 \%$ in the flowers, where glucose is the most abundant sugar, followed by fructose and sucrose. Hibiscus also contains mucilage and pectin, acid and neutral heterogeneous polysaccharides characteristic of plants, located in specialized cells (mucilage cells).

Textiles have long been recognized as media to support the growth of microorganisms such as bacteria and fungi. The growth of microorganism on textiles during use and storage negatively affects the wearer as well as the textile itself. Natural fibers such as wool are ideal for the growth of microorganisms at the suitable conditions such as moisture and appropriate temperature. The large surface area and natural moisture of textiles also assist the growth of microorganisms on the fabric [3-5].

Since microorganisms have caused the generation of unpleasant odor, stains and discoloration in the fabric, a reduction in fabric mechanical strength and an increased likelihood of contamination, to minimize the microorganism growth on textile is highly desirable. In order to obtain the greatest benefit, an ideal antimicrobial treatment of textiles should satisfy a number of requirements. Various methods, depending on the particular active agent and fiber type, have been developed or are under development to confer antimicrobial activity to textiles. Inorganic, organic and natural antibacterial agents have been applied on textiles to be able to give antimicrobial properties on natural fibers. Some metallic compounds based on metals like silver, copper, tin and mercury were mainly prefered for inorganic antibacterial agents [6-9].

This research aims to evaluate the dyeing ability and potential antibacterial activity of hibiscus using different inorganic mordant reagents against a human pathogen Staphylococcus Aureus (S. Aureus). The study investigates the effect of dye application methodsand mordant existence on the dye absorption behavior and fastnessproperties as well as the antibacterial activities of wool fabrics. Antibacterial activity retention of dyed fabrics is also examinedafter washing treatment.

\section{EXPERIMENTAL WORK}

\section{Materials}

$100 \%$ wool fabric was purchased from Yunsa, Turkey (166 g/m², 23 warp ends/cm, 24 weft ends/cm), dried Hibiscus plantswere obtained from Safran Natural and Organic Products Co (Turkey). Formic acid, nonionic detergent, $\mathrm{CuSO}_{4} \cdot 5 \mathrm{H}_{2} \mathrm{O}$ and $\mathrm{SnCl}_{2}$ were supplied by Merck (Germany).

$S$. aureus used was grown in the laboratory. Mueller Hinton agar (LAB 039) was supplied from LAB M (United Kingdom). Triptic soy broth was bought from Merck (Germany).

\section{Methods}

In this work, dyeing of wool with hibiscus and mordanting with $\mathrm{SnCl}_{2}$ and $\mathrm{CuSO}_{4}$ according to three application methods (pre-, meta- and post- mordanting) were examined. Then the antibacterial activity of inoculated wool fabric in two different metallic salts, $\mathrm{SnCl}_{2}$ and $\mathrm{CuSO}_{4}$, was investigated.

The mordanting application methods are listed below:

- Pre-mordanting (HSn-pr: for $\mathrm{SnCl}_{2} / \mathrm{HCu}-p r$ for $\mathrm{CuSO}_{4}$ ): Wool fabric samples were treated with the mordant and then dyed with hibiscus extract.

- Meta-mordanting (HSn-m: for $\mathrm{SnCl}_{2} / \mathrm{HCu}-\mathrm{m}$ : for $\mathrm{CuSO}_{4}$ ): The mordant was added in the hibiscusdye bath itself.

- Post-mordanting (HSn-po: for $\mathrm{SnCl}_{2} / \mathrm{HCu}-\mathrm{po}$ : for $\mathrm{CuSO}_{4}$ ): The dyed wool fabric samples were treated with a mordant at the end.

\section{Extraction of hibiscus:}

Dry Hibiscus flowers and leaves were crushed and dissolved in distilled water and allowed to boil in a beaker kept over water bath for quick extraction for 3 hours. All the colors were extracted from the flowers by the end of 3 hours. The solution was filtered for further uses.

The wool fabrics were first scoured with $0.5 \%$ nonionic detergent in the bath with $\mathrm{F}: \mathrm{L}$ (fabric to liquor ratio) $1: 20$ for $30 \mathrm{~min}$ at $60^{\circ} \mathrm{C}$. The scoured wool fabric samples $(10 \mathrm{~g})$ were dyed according the three mordanting methods used copper sulphate and tin (II) chloride, respectively; the dyeings were rinsed thoroughly in tap water and allowed to dry in the open air. (Formic acid was used for adjusting the $\mathrm{pH} 5$ ). Mordanting and dyeing processes were given in table 3.

Mordanting of wool:

For mordanting treatment, woolen fabric samples were immersed in the warm mordant solution $(10 \mathrm{~g} / \mathrm{L})$. Temperature of the mordanting bath was raised till $60^{\circ} \mathrm{C}$ and this process was continued for 30 minutes with constant stirring. After that, mordanted woolen yarn samples were removed, cooled and washed with tap water in order to remove superfluous mordant particles.

Dyeing processes:

Control dyeing (in the absence of mordant: $\mathrm{H}$ ).

Woolen fabric samples without any mordant were dyed using hibiscus solution (40 g/L) keeping $\mathrm{F}: \mathrm{L}$ ratio $1: 20$ at $\mathrm{pH}$ 5. Temperatures of the dye baths were raised till $60^{\circ} \mathrm{C}$ and left at that temperature for 30 min with regular stirring. The dyed woolen yarn samples were washed with $5 \mathrm{~g} / \mathrm{L}$ non-ionic detergent, then rinsed with tap water and dried in shade at room temperature.

The reflectance values of the undyed and dyed materials were measured using a Datacolor (USA) SF600 Plus spectrophotometer (a USAV $6.6 \mathrm{~mm}$ measuring plate was used) and then the CIELab values were calculated using illuminant D65 and $10^{\circ}$ standard observer values. The corresponding colour strength 


\begin{tabular}{|c|c|c|c|c|}
\hline \multicolumn{5}{|c|}{ MORDANTING AND DYEING PROCESSES } \\
\hline Pre-mordanting & & & & \\
\hline 1. step - mordanting & Mordant $(10 \mathrm{~g} / \mathrm{L})$ & $F: L 1: 20$ & $60^{\circ} \mathrm{C}$ & $30 \mathrm{~min}$ \\
\hline 2. step - dyeing & Hibiscus (40 g/L) & $F: L 1: 20$ & $60^{\circ} \mathrm{C}$ & $30 \mathrm{~min}$ \\
\hline \multicolumn{5}{|l|}{ Meta-mordanting } \\
\hline Hibiscus (40 g/L) & Mordant (10 g/L) & $F: L 1: 20$ & $60^{\circ} \mathrm{C}$ & $30 \mathrm{~min}$ \\
\hline \multicolumn{5}{|l|}{ Post-mordanting } \\
\hline 1. step - dyeing & Hibiscus (40 g/L) & $F: L 1: 20$ & $60^{\circ} \mathrm{C}$ & $30 \mathrm{~min}$ \\
\hline 2. step - mordanting & Mordant (10 g/L) & $F: L 1: 20$ & $60^{\circ} \mathrm{C}$ & $30 \mathrm{~min}$ \\
\hline
\end{tabular}

$(\mathrm{K} / \mathrm{S})$ values of the samples were calculated by using the Kubelka-Munk equation 1 [10].

$$
K / S=(1-R)^{2} / 2 R
$$

where $K$ is the absorption coefficient of the substrate, $S$ - the scattering coefficient of the substrate and $R-$ the reflectance of the dyed fabric at $\lambda_{\max }$.

The rubbing and wash fastnesses of the dyed wool fabrics were determined according to ISO105-X12 [11] and ISO105:C06 (A1S) [12] standards, respectively. A1S fastness test was carried out at $40^{\circ} \mathrm{C}$ for $30 \mathrm{~min}$ in a $150 \mathrm{ml}$ liquor containing 10 steel balls. The change in color of the specimen and the staining of the adjacent fabric, were assessed with the reference to the original fabric, using the grey scale.

Antibacterial activity:

The antibacterial activities of the washed (5 times) and unwashed samples were evaluated according to the AATCC147-2004 Test Methods. Staphylococcus Aureus (SA - ATCC25923) as gram positive bacteria were studied.

Fabrics were cuts and placed on a lawn of bacteria in a Mueller Hinton agar plate. They incubated overnight at $37^{\circ} \mathrm{C}$. Each lawn was prepared by speading a $0.5 \mathrm{McF}$ arland suspension of bacteria in triptic soy brothusing a sterile swap. The inoculants used included Staphylococcus Aureus, S. aureus. Bactericidal activity was visually assessed to determine the zone of inhibition around the fiber mat after overnight incubation per the AATCC 147 protocol to evaluate antimicrobial efficacy of the scaffolds.

The samples were washed by using Standard Test Method ISO 105-C06 A1M (one wash of the standard method is equivalent to five home launderings). After washing, the samples were rinsed in pure cold water and dried in air; then the fabrics were tested for antibacterial activity as mentioned above. The inhibition zone was measured in $\mathrm{mm}$.

\section{RESULTS AND DISCUSSIONS}

Characterization of dye absorption behavior and fastness properties

Color characteristics of all the dyed/mordanted woolen fabric samples wereassessed in terms of CIEL ${ }^{*}, a^{*}, b^{*}, C$, hand K/S (color strength); results were given in table 4 .
Table 4

\begin{tabular}{|l|c|c|c|c|c|c|}
\hline \multicolumn{7}{|c|}{$\begin{array}{c}\text { COLOR VALUES AND COLOR STRENGTH } \\
\text { OF HIBISCUS DYED SAMPLES } \\
\text { (MORDANTED AND UNMORDANTED) }\end{array}$} \\
\hline & L $^{*}$ & $\mathrm{a}^{*}$ & $\mathrm{~b}^{*}$ & $\mathrm{C}^{*}$ & $\mathrm{~h}^{\circ}$ & $\mathrm{K} / \mathrm{S}$ \\
\hline H & 32.64 & 0.11 & -2.33 & 2.33 & 267.8 & 16.73 \\
\hline HSn-pr & 37.88 & -0.92 & 3.99 & 4.09 & 103.01 & 13.9 \\
\hline HSn-m & 34.74 & -0.1 & -1.34 & 1.35 & 265.61 & 16.6 \\
\hline HSn-po & 37.66 & -1.9 & -0.26 & 1.92 & 187.9 & 12.1 \\
\hline HCu-pr & 49.65 & 8.58 & 10.95 & 13.92 & 51.98 & 9.11 \\
\hline HCu-po & 49.95 & 8.95 & 11.66 & 14.7 & 52.5 & 10.21 \\
\hline
\end{tabular}

It has been observed from comparative evaluation of data presented in table 4 that mordantingwith tin has decreased Lightness values $\left(L^{*}\right)$. Metamordanted fabrics were lighter than the others if used $\mathrm{SnCl}_{2}$ as mordant. There are small differences in theLightness values between $\mathrm{HCu}-\mathrm{pr}, \mathrm{HCu}-\mathrm{m}$ and $\mathrm{HCu}-\mathrm{po}$.

The meta mordanting samples using $\mathrm{Sn}(\mathrm{HSn}-\mathrm{m})$ is slightly darker more red and blue. The color strengths of the meta-mordanted woollen fabric samples are significantly higher than their corresponding pre- and post mordanted samples in both mordants $\left(\mathrm{CuSO}_{4}\right.$ and $\mathrm{SnCl}_{2}$ ). It has been observed that there is marginal increase in color strength (K/S) in thecase of tin mordanted samples compared with those of the copper mordanted samples.

The colour fastness against $40^{\circ} \mathrm{C}$ washings and rubbing are given in table 5 . As shown in table 5 , the colour change values werefound to be between 4 and 5 , and the staining test results of adjacent multifibres were generally found to be $4-5$ greyscale ratings.

The colour fastness to rubbing values of all samples was quite good $(4+)$.

\section{Antibacterial efficiency}

The antimicrobial activity of mordanted/dyed wool fabrics were studied in different mordanting application methods using tin chloride and copper sufate as a mordanting reagentagainst pathogenic bacterial strain, Gram-positive (Staphylococcus aureus, S. Aureus, SA - ATCC25923). 
COLOUR FASTNESS VALUES OF THE DYED SAMPLES

\begin{tabular}{|l|c|c|c|c|c|c|c|c|c|}
\hline & Colour change & \multicolumn{6}{|c|}{ Staining* } & \multicolumn{2}{c|}{ Rubbing } \\
\hline & & CA & Co & PA & PES & PAN & Wo & Dry & Wet \\
\hline H & 4 & $4-5$ & $4-5$ & 5 & 5 & $4-5$ & 5 & $4-5$ & $4-5$ \\
\hline HSn-pr & 5 & 5 & 5 & 5 & 5 & 5 & 5 & 5 & $4-5$ \\
\hline HSn-m & 5 & 5 & 5 & 5 & 5 & 5 & 5 & 5 & 5 \\
\hline HSn-po & 5 & 5 & $4-5$ & 5 & $4-5$ & 5 & 5 & 5 & 5 \\
\hline HCu-pr & $4-5$ & $4-5$ & 4 & 4 & $4-5$ & 5 & 5 & 5 & 5 \\
\hline HCu-m & 5 & $4-5$ & $4-5$ & $4-5$ & 4 & 5 & 5 & $4-5$ & $4-5$ \\
\hline HCu-po & 4 & $4-5$ & $4-5$ & $4-5$ & $4-5$ & $4-5$ & $4-5$ & $4-5$ & $4-5$ \\
\hline
\end{tabular}

* CA: Cellulose Asetat; Co: Cotton; PA: Polyamide; PES: Polyester; PAN: Acrilic; Wo: Wool

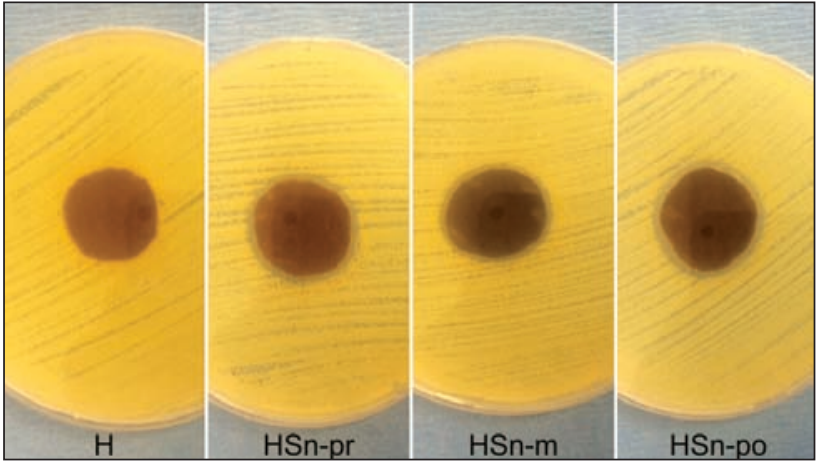

Fig. 1. Antibacterial activity of unmordonted and tin chloride-mordantedwool fabrics

\begin{tabular}{|c|c|c|}
\hline \multicolumn{3}{|c|}{$\begin{array}{c}\text { ANTIBACTERIAL EFFECT OF WASHED AND } \\
\text { UNWASHED TIN CHLORIDE TREATED } \\
\text { WOOL FABRICS }\end{array}$} \\
\hline \multirow{2}{*}{$\begin{array}{l}\text { Mordanting } \\
\text { application method }\end{array}$} & \multicolumn{2}{|c|}{$\begin{array}{l}\text { Antibacteriel affect, } \\
\text { S. Aureus, mm zone }\end{array}$} \\
\hline & unwashed & washed \\
\hline $\mathrm{H}$ & - & - \\
\hline HSn-pr & 3.1 & 1.5 \\
\hline HSn-m & 2.0 & 2.0 \\
\hline HSn-po & 2.9 & 1.9 \\
\hline
\end{tabular}

ties as mordanting agents for dyeing wool fabrics with natural dyes.

- The antibacterial effect of pre and post mordanting method using tin chlorideagainst the bacteria $S$. Aureus was higher than meta- mordanting method.

- The antibacterial effect of tin salt was continuing after five times of washing for allmordanting methods.

In conclusion, natural dyes and antibacterial treatments are important for textiles and health. Using natural dyes, like hibiscus, give some advantages, such as less toxic, environmental friendly, non-carcinogenic and non-poisonous.

In addition to obtained good dyeing properties, high antibacterial activity was occuredusing of tin compound as mordanton wool fabrics. Further studies of the usage of tin mordants in lower concentrations may have apromising future in the textile and health sector.

\section{ACKNOWLEDGEMENTS}

I am thankful to Assoc Prof Aslı Baysal and Şirin Ustabaşı from Istanbul Aydin University (Vacotional School of Heath Services, Department of Medical LaboratoryTechnics), for their help in obtaining antibacterial efficiency test results. 


\section{BIBLIOGRAPHY}

[1] Shanker, R., Padma, S. Vankar., Dyeing cotton, wool and silk with Hibiscus mutabilis (Gulzuba). In: Dyes and Pigments, 2007, vol. 74, pp. 464-469.

[2] Centerchem Inc., Norwalk CK, Hibiscus-eco, 2015, 44740, pp.1-5.

[3] Ghaheh, F.S., Mortazavi, S.M., Alihosseini F., Fassihi, A., Nateri, A.S., Abedi, D. Assessment of antibacterial activity of wool fabrics dyed with natural dyes, In: Journal of Cleaner Production, 2014, vol. 72, pp. 139-145.

[4] Farouk, A., Moussa, S., Ulbricht, M., Textor, T. ZnO nanoparticles-chitosan composite as antibacterial finish for textiles, In: International Journal of Carbohydrate Chemistry, 2012, vol. 2012, pp. 1-8.

[5] Gao, Y., Cranston, R. Textile recent advances in antimicrobial treatments of textiles, In: Research Journal, vol. 78(1), pp. 60-72.

[6] Wang, X., Wang, C. The antibacterial finish of cotton via sols containing quaternaryAmmonium salts, In: J Sol-Gel Sci Technol, 2009, vol. 50, pp. 15-21.

[7] Yuranova, J.T., Rincon, A.G., Bozzi, A. Antibacterial textiles prepared by RF-plasmaand vacuum-UV mediated deposition of silver, In: J Photochem Photobiol A Chem, 2003, vol. 161, pp. 27-34.

[8] Hong, K.H., Sun, G. Antimicrobial and chemical detoxifying functions of cottonfabrics containing different benzophenone derivatives, In: Carbohydr Polym, 2008, vol. 71, pp. 598-601.

[9] Büyükakıncı, B.Y. Investigation of antibacterial activities of tin ions on wool fabric, In: Industria Textila, 2013, vol. 5, pp. 241-245.

[10] McDonald, R. Colour physics for Industry, 1997, Bradford: Society of Dyers and Colourists, 2nd Edn.

[11] BS EN ISO 105 X12-2002, Textiles, Tests for colour fastness, Colour fastness to rubbing, London: BSI, 2002.

[12] BS EN ISO 105 C06-1997, Textiles,Tests for colour fastness, Colour fastness to domestic and commercial laundering, London: BSI, 1997.

\section{Authors:}

B.Yeşim Büyükakıncı

Istanbul Aydın University

Faculty of Engineering, Department of Textile Engineering

Istanbul, TURKEY

byesimb2@gmail.com

Corresponding author:

B.Yeşim Büyükakıncı

byesimb2@gmail.com

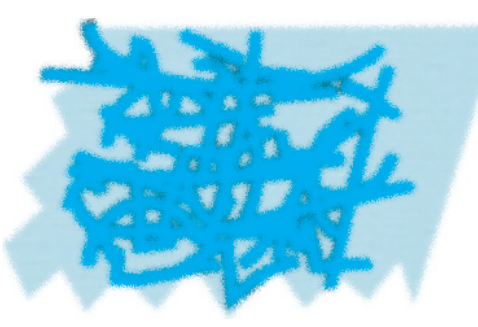




\section{An investigation of dyeability of wool fabric with red cabbage (Brassica oleracea L. var.) extract}

\section{REZUMAT - ABSTRACT}

Studiu asupra capacității de vopsire a țesăturii din lână cu extract din varză roșie (Brassica oleracea L. var.)

În acest studiu, țesăturile din lână au fost vopsite cu extractul apos de frunze de varză roșie proaspătă, cu conținut de kaempferol și quercetină ca principale specii de colorant. Plantele leguminoase Brassica sunt bogate în polifenoli, flavonoide și glucozinolați. Vopsirea a fost realizată cu și fără săruri metalice cum ar fi mordanții: $\mathrm{KAl}\left(\mathrm{SO}_{4}\right)_{2} \cdot 12 \mathrm{H}_{2} \mathrm{O}$, $\mathrm{CuSO}_{4} \cdot 5 \mathrm{H}_{2} \mathrm{O}, \mathrm{FeSO}_{4} \cdot 7 \mathrm{H}_{2} \mathrm{O}$ și $\mathrm{K}_{2} \mathrm{Cr}_{2} \mathrm{O}_{7}$. Metodele de pre- și meta-mordansare au fost utilizate în acest studiu. Țesăturile din lână mordansate au fost vopsite într-o baie de vopsire cu valori diferite ale $\mathrm{pH}$-ului. Valorile $\mathrm{pH}$-ului băii de vopsire au fost 3, 5, 7, 9 și respectiv 11. Diferite culori și nuanțe se pot obține cu diferite valori ale pH-ului. Țesăturile vopsite au fost evaluate prin măsurători de culoare și teste de spălare standard, transpirație, lumină, și rezistență la frecare. Colorantul absorbit de țesături și proprietățile de culoare au fost măsurate cu ajutorul unui spectrofotometru. Randamentul culorii țesăturilor vopsite se exprimă prin valorile KVS și CIELAB ( $L^{*}$, a* și $\left.b^{*}\right)$. Au fost studiate efectele mordantului, metodele de mordansare și valoarea $\mathrm{pH}$-ului băii de vopsire asupra valorilor culorii. Rezultate obținute sunt satisfăcătoare.

Cuvinte-cheie: țesătură din lână, mordant, varză roșie, Brassica oleracea, coloranți naturali, extract

\section{An investigation of dyeability of wool fabric with red cabbage (Brassica oleracea L. var.) extract}

In this study, woollen fabrics were dyed with the aqueous extract of fresh red cabbage leaves, containing kaempferol and quercetin as the main colorant species. Brassica vegetables are rich in polyphenols, flavonoids and glucosinolates. The dyeing was carried out with and without metal salts as mordants, such as $\mathrm{KAl}\left(\mathrm{SO}_{4}\right)_{2} \cdot 12 \mathrm{H}_{2} \mathrm{O}, \mathrm{CuSO}_{4} .5 \mathrm{H}_{2} \mathrm{O}$, $\mathrm{FeSO}_{4} \cdot 7 \mathrm{H}_{2} \mathrm{O}$ and $\mathrm{K}_{2} \mathrm{Cr}_{2} \mathrm{O}_{7}$. Pre-and meta-mordanting methods were used in this study. Mordanted wool fabrics were dyed in a dyebath prepared with different $\mathrm{pH}$ values. The $\mathrm{pH}$ values of bath were 3, 5, 7, 9 and 11, respectively. Different colors and shades can be obtained within different $\mathrm{pH}$ values. The dyed fabrics were evaluated through color measurements and standard wash, perspiration, light and rub fastness tests. The dye absorbed by the fabrics and color properties were measured using a spectrophotometer. The color yield of dyed fabrics is expressed by K/S, and CIELAB $\left(L^{*}, a^{*}\right.$ and $\left.b^{*}\right)$ values. The effects of mordant, methods of mordanting and $\mathrm{pH}$ value of the dye bath on the color values were studied. Finally, satisfactory results were obtained.

Keywords: Wool fabric, mordant, red cabbage, Brassica oleracea, natural dyes, extraction

\section{INTRODUCTION}

Red cabbage dyes are a natural pigment generally used as a food color. A colorful class of compounds called anthocyanins account of this color [1]. Anthocyanins (flavonoids), whichbelong to the family of flavonoids, are responsible for the red, blue, and purple colors in many fruits and vegetables $[2,5]$. The most naturally occurring anthocyanins occur as a glycoside and contain one of the several aglycone cores. The aglycone portion of red cabbage has been identified ascyanidine (figure 1) and is attached to the carbohydrate parts at both position 3 and 5 [8].

The color of anthocyanins is $\mathrm{pH}$ dependent and will not necessarily obey the Lambert-Beer law, because the color properties also depend on various other factors such as copigmentation with plant flavonoids. Anthocyanins comprise the largest group of water soluble pigments in plants [Bridle, 1997]. In 1993 Strack and Wray stated that anthocyanin is responsible for the red, purple and blue hues of plant fruits, flowers and leaves [6]. According to Mazza and
Miniati (1993), the prevalent form of anthocyanins at $\mathrm{pH}$ values $<2.0$ is the red flavylium cation, which undergoes various structural transformations with increasing pH values [2], [21]. The list of the six most

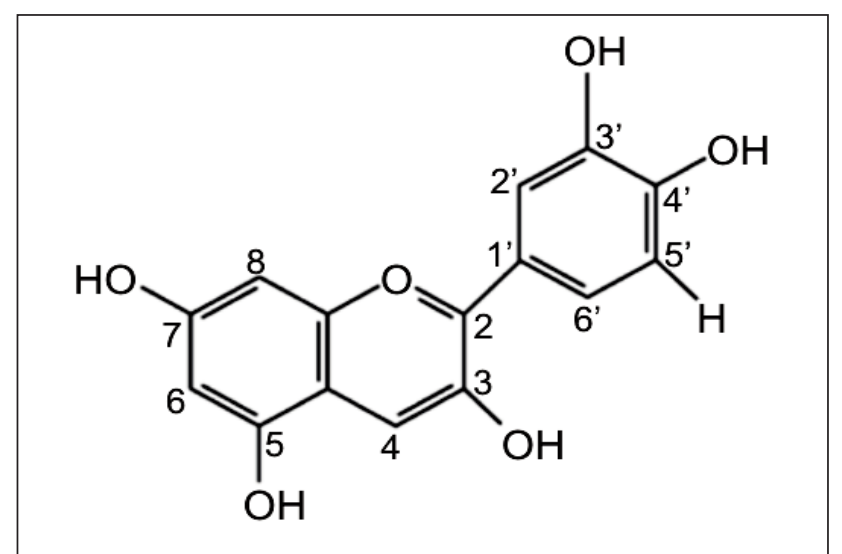

Fig. 1. Molecular structure of cyaniding, the common anthocyanin aglycone core present in cabbage red [8], [2], [4] 


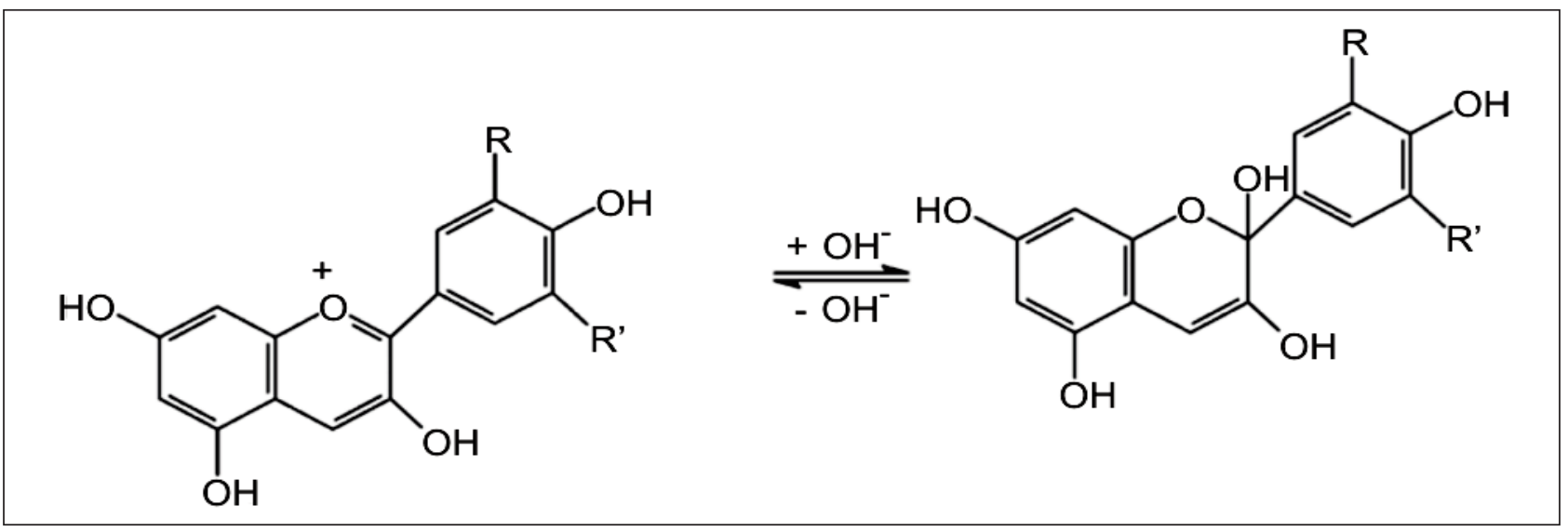

Fig. 2. Chemical structures of the two forms of anthocyanin aglycone cores responsible for $\mathrm{pH}$ indicator in cabbage red color [1]

widespread anthocyanins with their structural attributes areshown in table 1 [9]. In additionanthocyanin as a natural $\mathrm{pH}$ indicator is used in the chemical industry. The anthocyanin color depends on its structure, number and position of the hydroxyl and methoxyl groups present in its composition, and the structural forms [9].

Table 1

\begin{tabular}{|l|l|c|}
\hline \multicolumn{1}{|c|}{ Name } & \multicolumn{1}{|c|}{ Color } & $\begin{array}{c}\lambda_{\text {max }} \text { in acidic } \\
\text { methanol }\end{array}$ \\
\hline Cyanidin & Blue-red & 535 \\
\hline Delphinidin & Purple-blue & 546 \\
\hline Malvidin & Purple & 542 \\
\hline Pelargonidin & Scarlet-red & 520 \\
\hline Peonidin & Blue-red & 532 \\
\hline Petunidin & Purple-blue & 543 \\
\hline
\end{tabular}

Theaglycone core can exist as a positively charged oxonium ion and is termed as a flavylium cation in acidic solution as shown in figure 2 . The flavylium cation can exist in equilibrium with a colorless pseudo-base form in basic $\mathrm{pH}$ [1].

In light of all this very important information, we investigated whether or not the aqueous extract of red cabbage leaf, which is mostly used for coloring foodstuffs, could be used as a dye source in the dyeing of wool fabrics. Woolen fabric with mordant agents was used for this asit wasnecessary to prepare the fabric for coloring. Mordant materials and mordant methods constitute the most important steps in natural dyeing.

It was found that the mordant is more important than the dye itself because the color fastness of the dyed materials is determined according to the mordant type, concentration, method of application, $\mathrm{pH}$ of the dyeing media and nature of both substrate and dye used. A link is formed between the dyestuff and fabric when the mordant is fixed on the fiber and is also combined with the dyestuff. This allows a certain dye with no affinity for the fabric to be fixed.
Natural dyes mainly include those from vegetable sources such asthe leaves, stems, roots, barks and flowers of plantsand those from animal sources like Lac from the Laccifera insect, Kerms dye from the Kermes vermilioPlanchoninsect and cochineal dye from Dactylopius coccus Costa. In addition, there are many mineral coloring matters which produce natural dye effects on fabric [10].

It can be concluded that red cabbage dyes are generally used as colorants for food, cosmetics, chemistry and medical applications in the technical literature. However, in this paper, as a new application area, the coloring of textile materials with red cabbage dye was investigated as a different application field. In the present study, extracts from fresh red cabbage leaves were chosen as a source of natural dyes. The influence of mordant type, methods of mordanting and $\mathrm{pH}$ of the dyebath on color depth and shade was also studied.

\section{MATERIALS AND METHODS}

\section{Materials}

The materials used in this study were previously pretreated (soaping with non-ionic detergent for 4-5 min at $50^{\circ} \mathrm{C}$ ), and were $100 \%$ wool fabrics weighing $360 \mathrm{~g} / \mathrm{m}^{2}$ provided (by Yünsa/Turkey). As a natural dyesource, commercially available fresh red cabbage leaves were used.

\section{Extraction of Pigments}

One kilogram of fresh red cabbage leaves grown in Turkey were picked in season. They were crushed and sequentially extracted by being soaked in 2 liters of water for 2 hours at $100^{\circ} \mathrm{C}$. After filtration, the liquor extract was concentrated for 1 hour at $95^{\circ} \mathrm{C}$. The $\mathrm{pH}$ values for the aqueous solution were approx. 4.5-5. This solution was used in a dye-bath after $\mathrm{pH}$ arrangement for the dyeing of the woolen fabrics.

\section{Mordants and mordanting}

The dyeing of fabrics with natural dyes often leads to problems such as narrow shade range, and lower color fastness of the dyed textiles. Attempts to overcome these problems have been mainly focused on 
the use of mordants. In addition, to create affinity between the dye and fiber, mordantsare used which can also change the hue of certain dyes. Different mordants used with the same dye may darken, brighten or drastically alter the final color of the dyed fiber [14-15]. According to Kadolph and Casselman, mordanting generally improved dye performance and helped the dyer to achieve a broad spectrum of colors on a wide range of fibers with extensive shade ranges and better fastness properties [13]. Samanta and Agarwal (2009) presented a comprehensive review of studies available on different types of mordants, mordanting methods and their effects on natural dyeing for a variety of textile materials. The most commonly used mordants (technical grade) in natural dyeing are aluminum potassium sulfate, potassium dichromate, stannous chloride, ferrous sulfate and copper sulfate [12]. In this paper, the dye was prepared by extracting the juice from fresh red cabbage leaves for mordanting, copper sulfate $(\mathrm{Cu})$, ferrous sulfate $(\mathrm{Fe})$, potassium dichromate $(\mathrm{Cr})$ and aluminum potassium sulfate $(\mathrm{Al})$ were used. Pre-and meta-mordanting methods were used. Both methods were performed at a materials to liquor ratio of 1:40 for one hour at $100^{\circ} \mathrm{C}$. As shown in figure 3 , before dyeing, the dyebath was prepared by using five different $\mathrm{pHs}$.

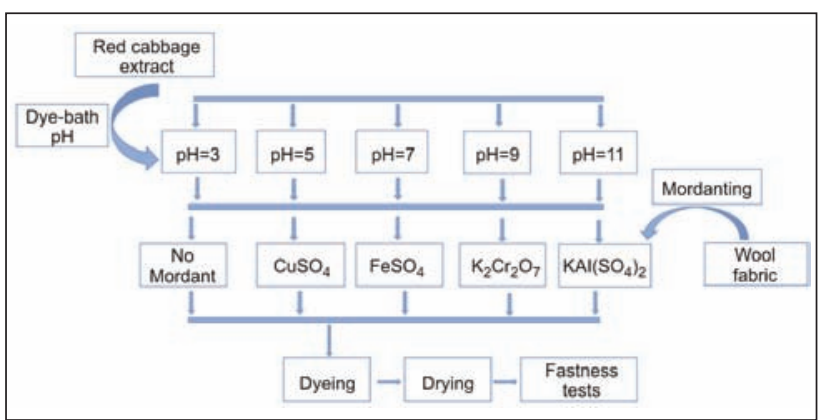

Fig. 3. Trial plan for the combination of red cabbage extract, different $\mathrm{pH}$ of dye-bath and mordant

Metallic mordants are the water-soluble salts of metals. Some transition metal ions can bond strongly with natural dye molecules, producing deep colors on the fabric. Other non-transition elements can also produce colors but with less intensity [16].

\section{Dyeing method}

The mordanted wool samples were heated in a liquor ratio of $40: 1$ (200 $\mathrm{ml}$ of extract) at $100^{\circ} \mathrm{C}$ for 1 hour. The woolen fabrics were dyed under a variety of conditions including different $\mathrm{pHs}$. The $\mathrm{pH}$ of the dyebath was varied from 3 to 11 by adding buffer solution (acidic acid + sodium carbonate), and the dyeing temperature $\left(100^{\circ} \mathrm{C}\right)$ and duration $(60 \mathrm{~min})$ were fixed so as to achieve maximum dye uptake. A fixed bath temperature for each dyeing process and a constant stirring velocity were maintained by a shaking oil bath (HT Roaches Brand MB). In the meta-mordanting methods, the mordant agent, dye solution and woolen fabric were placed in a sample dyeing

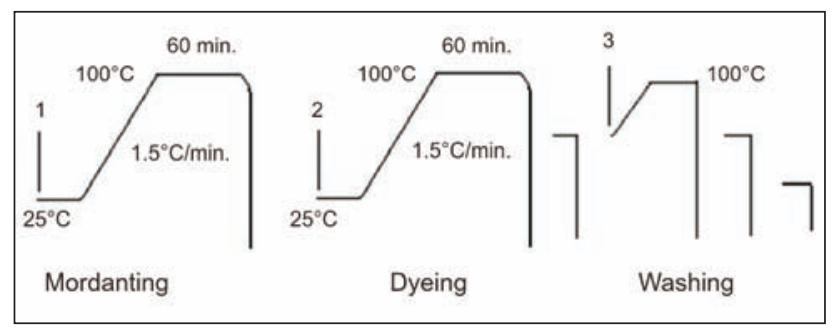

Fig. 4: Processes of mordanting, dyeing and washing for wool fabrics: 1 - mordant agent + wool; 2 - mordanted fabric + dye solution; 3 - dyed fabric + non-ionic soap

machine tube, and then this mixture was heated at $100^{\circ} \mathrm{C}$ for 1 hour. The mordanting, dyeing and washing methods are shown in figure 4 . At the same time, non-mordanted dyeing was carried out too. All applications were performed by an exhaustion method. Finally, the dyed samples were air-dried at room temperature.

\section{Instrumental color measurement}

The dye absorbed by the fabrics and color properties were measured using a spectrophotometer (Minolta 3600d) under illuminant D65, with a $10^{\circ}$ standard observer. The $K / S$ values which were employed as the dye uptake or color strength were calculated for each dyed specimen by using the Kubelka-Munk equation (Eq. 1) as follows:

$$
K / S=(1-R)^{2} / 2 R
$$

where $K$ is the coefficient of absorption; $S$ - the coefficient of scattering; $R$ - the reflectance value of the fabric at peak wavelength. As for the color properties of the dyed fabric, CIE $L^{*}, a^{*}$, and $b^{*}$ were obtained. $L^{*}$ describes lightness (100 = white, $0=$ black); $a^{*}$ measures redness or greenness; $b^{*}$ measures yellowness or blueness in the CIE system.In addition, for the detection of changes, the color differences of the samples (Delta E) were calculated according to Equation 2: [17].

$$
\Delta \mathrm{E}=\sqrt{\left(\Delta L^{*}\right)^{2}+\left(\Delta a^{*}\right)^{2}+\left(\Delta b^{*}\right)^{2}}
$$

\section{Fastness properties}

Fastness properties were investigated on the dyed woolen fabrics in terms of rubbing, washing, perspiration and light. Dry and wet rub fastness was tested by ISO 105 X12 [26]; washing fastness was examined by ISO $105 \mathrm{CO2}$ [24]; with a soap solution of $5 \mathrm{~g} / \mathrm{L}$ (liquor ratio $50: 1$ ) for $30 \mathrm{~min}$ at $40^{\circ} \mathrm{C}$, the perspiration fastness was evaluated with ISO 105 E04 [27]; light fastness was measured by ISO 105 B02 and was related to the standard scale of blue dyeings (values 1-8, where $1=$ poor and $8=$ excellent) [25]. Fading and staining of adjacent fabrics in color were determined using gray scales (values 1-5, where $1=$ poor and $5=$ excellent).

\section{RESULTS AND DISCUSSION}

Red cabbage is a very popular plant in Turkey. For example, it isgenerally used in salads, as a colorant agent in the food industry and in some folk medicine 


\begin{tabular}{|c|c|c|c|c|c|c|c|}
\hline $\begin{array}{c}\text { Dye-bath } \\
\text { pH }\end{array}$ & Color & $\begin{array}{c}\text { Images of } \\
\text { dyed samples }\end{array}$ & $L^{*}$ & $a^{*}$ & $\boldsymbol{b}^{*}$ & $K / S$ & $\Delta \mathrm{E}$ \\
\hline 3 & Ecru & & 61.89 & 2.7 & 7.72 & 2.03 & 11.46 \\
\hline 5 & Beige & & 64.04 & 2.5 & 18.97 & 2.65 & - \\
\hline 7 & Khaki & & 53.68 & 10.54 & 25.47 & 6.7 & 14.64 \\
\hline 9 & Celadon & & 64.58 & 1.13 & 14.11 & 2.11 & 5.08 \\
\hline 11 & Camel & & 61.92 & 4.41 & 9.35 & 2.18 & 10.03 \\
\hline
\end{tabular}

applications. In this paper, red cabbage was investigated in another industrial application area, too, as a textile colorant agent. Thisstudy was carried out to determine the different phenolic contents of red cabbage extract. Some researchers have shown that the phenolic content that is obtained from the extract of red cabbage leaves hasa higher value [Ahmad, 2008]. It is soluble in water and sensitive to $\mathrm{pH}$ changes [20]. The stability of this pigment during extraction from natural sources has also been reported [21-23]. In this study, these phenolic compounds were used to dye the woolen fabrics. Woolfabric dyed with different mordants, exhibits noticeable color changes, as indicated in tables 2-3.

\section{Effects of $\mathrm{pH}$ values on color values and color efficiencies}

It was understood that different values of dye bath $\mathrm{pH}$, different mordanting types and different mordant agent had aconsiderable effect on the color of the dyed wool fabrics. In this context, the experimental results are shown in tables $2-3$. The results show that non-mordanted samples caused beige, khaki, celadon etc. compared to the mordanted samples.

In general, mordanted samples have different shades such as pale pink, purple, shiny violet, khaki, lime green, gray, light gray, beige, light purple, pale blue, ecru, pale scarlet, light claret red, buff, and celadon green. A very broad color palette was obtained. A random distribution among all colors is seen. This can be used to advantage. For instance, by using only one dyestuff source it is possible obtain a lot of color shades on the wool fabric. Of course, this provides a great advantage in industrial applications.

\section{K/S determination for wool fabrics after dyeing}

It is a known fact that the color yield on the fabric is related to some parameters such as dye type, mordant agent, mordant type, dyebath $\mathrm{pH}$ etc. According to Tang et al., the colorimetric properties of the dyed wool fabrics, such as lightness $\left(L^{*}\right)$, redness-yellowness $\left(a^{*}\right)$, blueness-greenness $\left(b^{*}\right)$ and color strength $(K / S)$, are greatly dependent on the chemical nature of mordants and fibers and the metal ion complex forming ability of the dye and the fiber [18]. In this paper, five different $\mathrm{pH}$ values were used in the dyebath solutions. Two mordanting methods were used in the dyeing processes, namely pre- and metamordanting. Using different metal salts and different dyebath $\mathrm{pH}$ values caused the outcomes shown in tables 2-4. When tables 2-4 are analyzed, generally, it can be seen that by changingthe $\mathrm{pH}$ of the dyebath gradually from acid to alkaline, the color yields of samples increased. The highest increases (max. score 13.72) were observed in experiments on premordanted samples with copper sulfate. According to Kubelka-Munk, a higher $K / S$ value means more dye uptake. The K/S valueswhich is related to the change of dyebath $\mathrm{pH}$, showed a significant increase, but aluminum, iron and chromium ions did not showsimilar features. Although the dyed samples which were mordanted with copper sulfate had the highest $K / S$ values from 4.81 to 13.72 , the lowest $K / S$ values from 1.03 to 3.95 were obtained in samples mordanted with aluminum potassium sulfate. Electrostatic forces between the positively charged side chains of the protein fiber and the dye molecule were observed to play a dominant role in dye adsorption. The significant ecru shade of the pre-mordanted sample ( $a^{*}: 2.7$ ) changed and the $a^{*}$ value became 6.89 , which represents the pink shade. Also, there were changes in the $L^{*}$ values, but these changes were slight when compared with the $a^{*}$ and $b^{*}$ values. In terms of the $L^{*}$ values, all experiments showed a narrow interval from 50 to 75 (table 4).

For the detection of these alterations, the color differences of the samples $(\Delta E)$ were calculated (Eq.2) and the results are shown in table 5. A neutral (normally the extracted dye solution has a $\mathrm{pH}$ value of 5 so the results of the dyeing conducted at $\mathrm{pH}=5$ were selected as a reference) dyebath $\mathrm{pH}$ (5) valuewas selected as a reference value and all dyebath $\mathrm{pH}$ change was analyzed in terms of color differences. 
Table 3

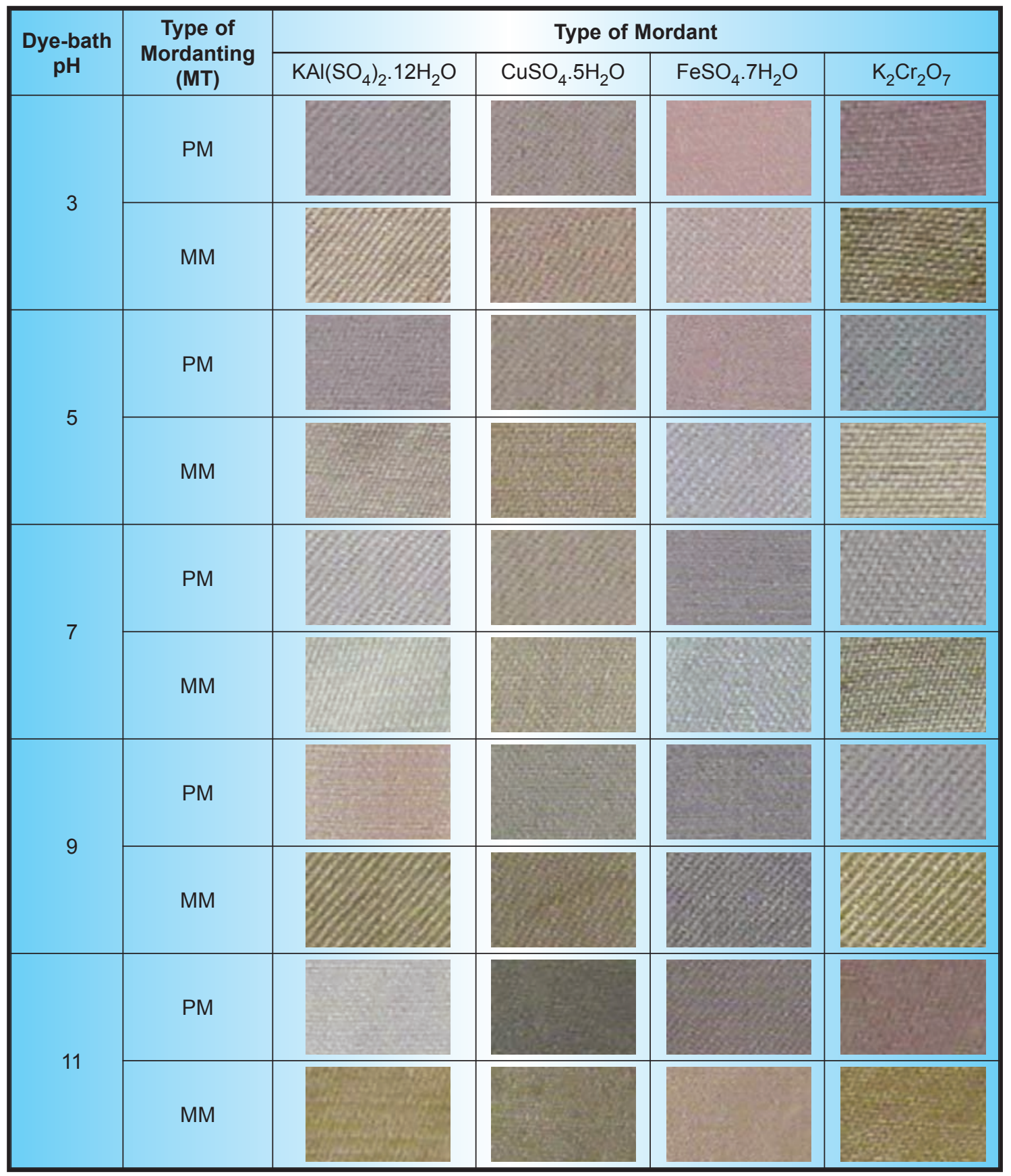

Table 4

\begin{tabular}{|c|c|c|c|c|c|c|c|c|c|c|c|c|c|c|c|c|c|}
\hline \multirow{2}{*}{ MT } & \multirow{2}{*}{$\begin{array}{c}\text { Dye- } \\
\text { bath } \\
\text { pH }\end{array}$} & \multicolumn{3}{|c|}{$\mathrm{Al}$} & \multicolumn{5}{|c|}{$\mathrm{Cu}$} & \multicolumn{3}{|c|}{$\mathrm{Fe}$} & \multicolumn{5}{|c|}{$\mathrm{Cr}$} \\
\hline & & $L^{*}$ & $a^{*}$ & $b^{*}$ & $K / S$ & $L^{*}$ & $a^{*}$ & $b^{*}$ & $K / S$ & $L^{*}$ & $a^{*}$ & $b^{*}$ & $K / S$ & $L^{*}$ & $a^{*}$ & $b^{*}$ & $K / S$ \\
\hline \multirow{5}{*}{ PM } & 3 & 54.4 & 6.99 & 16.26 & 1.03 & 53.93 & 6.89 & 21.08 & 5.41 & 50.98 & -2.65 & 7.28 & 3.82 & 56.84 & 4.66 & 13.91 & 3.22 \\
\hline & 5 & 52.56 & 4.67 & 12.27 & 3.85 & 53.15 & 6.05 & 22.53 & 5.83 & 55.18 & -1.19 & 7.94 & 3.11 & 55.73 & -2.93 & 13.1 & 3.83 \\
\hline & 7 & 61.58 & 2.64 & 16.38 & 2.81 & 53.65 & 5.17 & 23.63 & 6.91 & 56.48 & 2.36 & 12.22 & 3.65 & 61.95 & -1.22 & 17.14 & 3.06 \\
\hline & 9 & 62.74 & 8.58 & 26.68 & 3.95 & 47.90 & 3.63 & 21.35 & 8.73 & 64.15 & 7.86 & 18.94 & 3.30 & 61.98 & -1.91 & 15.67 & 3.02 \\
\hline & 11 & 62.79 & 2.73 & 19.24 & 2.98 & 39.75 & 2.94 & 20.08 & 13.72 & 66.82 & 8.56 & 18.74 & 2.25 & 54.31 & 8.74 & 26.67 & 7.34 \\
\hline \multirow{5}{*}{ MM } & 3 & 67.79 & 7.48 & 16.28 & 1.79 & 55.67 & 6.77 & 21.47 & 4.81 & 58.6 & 3.62 & 17.29 & 4.52 & 51.42 & 3.94 & 17.37 & 5.19 \\
\hline & 5 & 67.68 & 4.71 & 13.31 & 1.64 & 51.67 & 6.28 & 23.78 & 6.42 & 54.76 & -1.8 & 5.99 & 2.83 & 64.57 & 3.49 & 17.14 & 2.54 \\
\hline & 7 & 75.07 & -0.69 & 12.25 & 1.07 & 55.27 & 3.79 & 23.56 & 6.32 & 51.95 & -3.19 & 8.07 & 3.85 & 63.17 & 1.6 & 14.46 & 2.28 \\
\hline & 9 & 62.30 & 5.78 & 23.57 & 3.51 & 46.53 & 3.66 & 21.36 & 9.53 & 45.27 & 0.07 & 11.72 & 6.59 & 63.36 & 5.45 & 25.24 & 3.71 \\
\hline & 11 & 66.18 & 9.01 & 28.13 & 3.36 & 43.85 & 5.50 & 22.88 & 11.22 & 49.95 & 7.52 & 22.57 & 7.45 & 60.63 & 8.76 & 27.57 & 4.88 \\
\hline
\end{tabular}

PM: Pre-mordanting, MM: Meta-mordanting, MT: Type of Mordanting 
Table 5

\begin{tabular}{|cccccc|}
\hline \multirow{2}{*}{ MT } & $\begin{array}{c}\text { Dye- } \\
\text { bath } \\
\text { pH }\end{array}$ & $\mathbf{A l}$ & $\mathrm{Cu}$ & $\mathrm{Fe}$ & $\mathrm{Cr}$ \\
\cline { 3 - 6 } & $\mathbf{3}$ & 4.97 & 1.85 & 4.50 & 7.71 \\
$\mathbf{4} \mathbf{P M}$ & $\mathbf{7}$ & 10.12 & 1.49 & 5.71 & 7.61 \\
& $\mathbf{9}$ & 18.07 & 5.90 & 16.83 & 6.83 \\
& $\mathbf{1 1}$ & 12.53 & 13.97 & 18.63 & 17.95 \\
\hline \multirow{4}{*}{$\mathbf{M M}$} & $\mathbf{3}$ & 4.06 & 4.65 & 13.11 & 13.16 \\
& $\mathbf{7}$ & 9.21 & 4.38 & 3.76 & 3.57 \\
& $\mathbf{9}$ & 11.63 & 6.26 & 11.24 & 8.42 \\
& $\mathbf{1 1}$ & 15.50 & 7.91 & 19.62 & 12.33 \\
\hline
\end{tabular}

Table 5 shows that the highest $\Delta \mathrm{E}$ value (MM; 19.62) was obtained from the sample mordanted with ferrous sulfate. In other words, the images of dyed samples supported this claim. On the other hand, the lowest color change (PM; 1.49) was observed from the sample mordanted with copper sulfate. Briefly, it may be said that with different dye bath pHs, mordant agents and mordanting types, different colors and shades can be obtained.

There are no correlations between the highest and the lowest values of red cabbage leaves extract when using different dye bath pHs, mordant agents

Table 6

\begin{tabular}{|c|c|c|c|c|c|c|c|c|c|c|c|}
\hline \multirow{3}{*}{$\begin{array}{l}\text { Type } \\
\text { of ion }\end{array}$} & \multirow{3}{*}{$\begin{array}{c}\text { Dye- } \\
\text { bath } \\
\text { pH }\end{array}$} & \multirow{3}{*}{ MT } & \multirow{2}{*}{\multicolumn{2}{|c|}{ Rubbing }} & \multicolumn{4}{|c|}{ Perspiration fastness } & \multirow{2}{*}{\multicolumn{2}{|c|}{$\begin{array}{c}\text { Wash } \\
\text { fastness }\end{array}$}} & \multirow{3}{*}{$\begin{array}{c}\text { Light } \\
\text { fastness }\end{array}$} \\
\hline & & & & & \multicolumn{2}{|c|}{ Acidic } & \multicolumn{2}{|c|}{ Alkaline } & & & \\
\hline & & & Wet & Dry & Alt. & St. & Alt. & St. & Alt. & St. & \\
\hline & 3 & & 5 & 5 & 5 & 4 & 5 & 4 & 5 & 3 & 2 \\
\hline & 5 & & 5 & 5 & 5 & 4 & 5 & 3 & 5 & 3 & 2 \\
\hline & 7 & NM & 5 & 5 & 5 & 5 & 5 & 5 & 5 & $4-5$ & 3 \\
\hline & 9 & & 5 & 5 & 5 & 5 & 5 & 5 & 5 & $4-5$ & 3 \\
\hline & 11 & & 4 & 4 & 5 & 5 & 5 & 5 & 5 & 5 & 3 \\
\hline \multirow{10}{*}{ Al } & \multirow{2}{*}{3} & PM & 5 & 5 & 4 & 4 & $4-5$ & 4 & $4-5$ & 4 & 3 \\
\hline & & MM & 5 & 5 & $4-5$ & $4-5$ & $4-5$ & $4-5$ & $4-5$ & 4 & $5-6$ \\
\hline & \multirow{2}{*}{5} & PM & 5 & 5 & $4-5$ & 5 & $4-5$ & 4 & 4 & 4 & 2 \\
\hline & & MM & 5 & 5 & $4-5$ & 3 & $4-5$ & 3 & $4-5$ & $2-3$ & 4 \\
\hline & \multirow[b]{2}{*}{7} & PM & 5 & 5 & $4-5$ & $4-5$ & $4-5$ & $4-5$ & 4 & $3-4$ & 2 \\
\hline & & MM & 5 & 5 & $4-5$ & $4-5$ & $4-5$ & $4-5$ & 4 & 3 & $3-4$ \\
\hline & \multirow{2}{*}{9} & PM & 5 & 5 & 5 & 5 & 5 & 5 & 5 & 5 & 2 \\
\hline & & MM & 5 & 5 & 5 & 5 & 5 & 5 & 5 & 5 & 3 \\
\hline & \multirow{2}{*}{11} & PM & 5 & 5 & $4-5$ & 3 & $4-5$ & 3 & $4-5$ & $4-5$ & 2 \\
\hline & & MM & 5 & 5 & 5 & 5 & 5 & 5 & 5 & 5 & 2 \\
\hline \multirow{10}{*}{ Cu } & \multirow{2}{*}{3} & $\mathrm{PM}$ & 5 & 5 & 5 & $4-5$ & 5 & $4-5$ & 5 & 5 & 5 \\
\hline & & MM & 5 & 5 & $4-5$ & $4-5$ & $4-5$ & $4-5$ & $4-5$ & $4-5$ & $5-6$ \\
\hline & \multirow{2}{*}{5} & PM & 5 & 5 & 5 & 5 & 5 & 5 & 5 & 5 & 5 \\
\hline & & MM & 5 & 5 & 5 & 5 & 5 & 5 & $4-5$ & 4 & 5 \\
\hline & \multirow{2}{*}{7} & PM & 5 & 5 & 5 & 5 & $4-5$ & $4-5$ & 4-5 & $4-5$ & $4-5$ \\
\hline & & MM & 5 & 5 & $4-5$ & 3 & $4-5$ & 4 & 4 & $2-3$ & 5 \\
\hline & & PM & 5 & 5 & $4-5$ & 3 & $4-5$ & 4 & 4 & 3 & 5 \\
\hline & $y$ & MM & 5 & 5 & $4-5$ & 3 & $4-5$ & 4 & 4 & $2-3$ & 5 \\
\hline & 11 & PM & $3-4$ & $3-4$ & 5 & $4-5$ & 5 & 4 & $4-5$ & 4 & $3-4$ \\
\hline & 11 & MM & 5 & 5 & 5 & 5 & 5 & 5 & 5 & 5 & 4 \\
\hline & & $\mathrm{PM}$ & 5 & 5 & $4-5$ & 4 & $4-5$ & 4 & $4-5$ & 4 & 2 \\
\hline & 3 & MM & 5 & 5 & 4-5 & $4-5$ & $4-5$ & 4-5 & $4-5$ & 4 & 2 \\
\hline & 5 & PM & 4-5 & 5 & 4-5 & 3 & $4-5$ & 3 & $4-5$ & 3 & 2 \\
\hline & 5 & MM & 5 & 5 & 4-5 & $4-5$ & 3 & 4 & $4-5$ & $4-5$ & 2 \\
\hline $\mathrm{Fe}$ & 7 & PM & 4-5 & 5 & 4 & $4-5$ & $4-5$ & $4-5$ & $4-5$ & $4-5$ & 3 \\
\hline re & $I$ & MM & 5 & 5 & $4-5$ & 4 & 4 & 3 & $4-5$ & 4 & 3 \\
\hline & 9 & PM & 4 & $4-5$ & $4-5$ & 4 & $4-5$ & 3 & 4 & 3 & 3 \\
\hline & $\mathbf{y}$ & MM & 5 & 5 & $3-4$ & $3-4$ & $3-4$ & $3-4$ & $4-5$ & $3-4$ & 3 \\
\hline & 11 & PM & 5 & 5 & 4-5 & $3-4$ & $4-5$ & $4-5$ & 4 & 4 & 4 \\
\hline & 11 & MM & 5 & 5 & 4-5 & $4-5$ & $4-5$ & 5 & $4-5$ & 5 & 3 \\
\hline & & $P M$ & 5 & 5 & 5 & $4-5$ & 5 & 5 & 5 & $4-5$ & $3-4$ \\
\hline & & MM & 5 & 5 & 5 & 5 & 5 & 5 & 5 & 5 & 2 \\
\hline & 5 & PM & 5 & 5 & 5 & 5 & 5 & 5 & $4-5$ & 4 & $3-4$ \\
\hline & 5 & MM & 5 & 5 & 4 & 4 & 4 & 4 & 4 & 4 & 2 \\
\hline $\mathrm{Cr}$ & 7 & PM & 5 & 5 & 5 & 5 & 5 & 5 & $4-5$ & $4-5$ & 3 \\
\hline UI & I & MM & 5 & 5 & 5 & 5 & 5 & 5 & 4 & 4 & 2 \\
\hline & 9 & PM & 5 & 5 & 5 & 5 & 5 & 5 & $4-5$ & $4-5$ & 3 \\
\hline & $y$ & MM & 5 & 5 & 5 & 5 & 5 & 5 & 5 & 5 & 2 \\
\hline & 11 & PM & 5 & 5 & 5 & 5 & 5 & 5 & 5 & 5 & 3 \\
\hline & 11 & MM & 5 & 5 & 5 & 5 & 5 & 5 & 5 & 5 & $2-3$ \\
\hline
\end{tabular}

St.: staining on wool; Alt.: color change; Wet: staining of wet wool fabric during rubbing; Dry: staining of dry wool fabric during rubbing 
and mordanting types. Nevertheless, the process should be conducted carefully. Althoughthe alkaline dyebaths showed higher color efficiencies, the woolen fabric could be damaged in this bath.

\section{Color fastness properties of dyed samples}

The rubbing, perspiration, wash and light fastness ratings of red cabbage leaves, extract on wool fabric at different shadesare given in table 6. Generally, it is apparent from this table that light fastness was poor (2-3 points), butthe light fastness of the dyed fabrics in the acidic dyebath $(\mathrm{pH}=3)$ was determined to have high values (5-6 points), in which fabrics were metamordanted with aluminum or copper sulfate.

All experiments showed that the light fastness properties of the mordanted fabrics had an increased score of 0.5-2 compared to non-mordanted fabrics. Red cabbage leaves, extract exhibits good wash, rubbing and perspiration fastness on wool fabric.

The scores of the pre- and meta-mordanting methods had showed the same values (4-5 points). These scores were very satisfactory. The chemistry of bonding dyes to fiber is complex. It involves direct bonding, $\mathrm{H}$-bonds, and hydrophobic interactions. In many ways, mordants help the binding of dyes to fabric by forming a chemical bridge from dye to fiber, thus improving the staining ability of a dye as well as increasing its fastness properties [19].

\section{CONCLUSIONS}

Natural dyes have become much more popular in recent years on account of their inherent composition. In approximately the last two decades, a large number of studies on this topic have been conducted. Nonetheless, there are still some problems such as reproducibility, the poor fastness of some natural dyes and the need to use metallic mordants etc. In spite of these negative issues, many researchers still continue with their work on natural dyes.

In this study, red cabbage leaves, extract was investigated to use as a natural dye. In this context, the aqueous extracts of fresh red cabbage leaves were used for dyeing wool fabrics, with pre-and meta-mordanting, using the mordants aluminum, copper sulfate, ferrous sulfate and potassium dichromate salts. These mordants were used as representatives which were commonly used in textile applications in the past. Furthermore, this study aimed to present an alternative dye source for the dyeing of woolen fabrics. Consequently, it was found that by using red cabbage leaves, extract, and depending on the mordant agent and mordanting type, different color shades can be obtained. Mordanting resulted in a significant improvement in the dye adsorption on the dyed wool fabrics and an increase in K/S values. Thereby, the presented results prove the possibility of using red cabbage leaves, extract as a sources for natural dyeing of woolen fabrics in the textile industry.

\section{BIBLIOGRAPHY}

[1] Chigurupati, N., Saiki, L., Gayser Jr, C., Dash, A.K. Evaluation of red cabbage dye as a potential natural color for pharmaceutical use. In: International Journal of Pharmaceutics, 2002, vol. 241, issue 2, pp. 293-299

[2] Degenhardt, A., Knapp, H., Winterhalter, P. Separation and Purification of Anthocyanins by High-Speed Countercurrent Chromatography and Screening for Antioxidant Activity. In: Journal Agric. Food Chem., 2000, vol. 48, issue 2, pp. 338-343

[3] Bridle, P., Timberlake, C.F. Anthocyanins as natural food colours-selected aspects. In: Food Chemistry,1997, vol. 58, issue 1-2, pp. 103-109

[4] Kim, D.O., Padilla-Zakour, O.I., Griffiths, P.D., Flavonoids and Antioxidant Capacity of Various Cabbage Genotypes at Juvenile Stage. In: Journal of Food Science, 2006, vol. 69, issue 9, pp. 685-689

[5] Walkowiak-Tomczak, D., Czapski, J.Colour changes of a preparation from red cabbage during storage in a model system. In: Food Chemistry, 2007, vol. 104, issue 2, pp. 709-714

[6] McDougall, G.J., Fyffe, S., Dobson, P., Stewart, D.Anthocyanins from red cabbage - stability to simulated gastrointestinal digestion. In: Phytochemistry, 2007, vol. 68, issue 9, pp. 1285-1294

[7] Harborne, J.B. Phytochemical methods: a guide to modern techniques of plant analysis. Chapman \& Hall, London, Third edition, 1998, UK

[8] Curtright, R., Rynearson, J.A., Markwell, J. Anthocyanins: model compounds for learning about more than pH. In: Journalof Chemical Education, 1996, vol. 73, issue 4, pp. 306-309

[9] Jackman, R.L., Smith, J.L. Anthocyanins and betalains. In: Hendry, G.A.F. and Houghton, J.D. Natural Food Colorants. London: Blackie Academic, pp. 183-241, 1996

[10] Ibrahim, S.F., El-Amoudy E.S., Shady, K.E. Thermal Analysis and Characterization of Some Cellulosic Fabrics Dyed by a New Natural Dye and Mordanted with Different Mordants. In: International Journal of Chemistry, 2011, vol. 3, issue 2, pp. 40-54

[11] Zarkogianni, M., Mikropoulou, E., Varella, E., Tsatsaroni, E. Colour and fastness of natural dyes: revival of traditional dyeing techniques. In: Color. Technol., 2010, vol. 127, issue 1, pp. 18-27

[12] Samanta, A.K., Agarwal, P. Application of natural dyes on textiles. In: Indian Journal of Fibre and Textile Research, 2009, vol. 34, issue 4, pp. 384-399 
[13] Kadolph, S.J., Casselman, K.D. In the Bag: Contact Natural Dyes. In: Textile Research Journal, 2004, vol. 22, issue 1-2, pp. 15-21

[14] Manhita, A., Ferreira, T., Candeias, A., Dias, D.B. Extracting natural dyes from wool - an evaluation of extraction methods. In: Anal BioanalChem, 2011, vol. 400, issue 5, pp. 1501-1514

[15] Yi, E., Cho, J.Y. Color Analysis of Natural Colorant-Dyed Fabrics. In: Color research and application, 2008, vol. 33, issue 2, pp. 148-157

[16] Dweck, A.C. Natural ingredients for colouring and styling. In: International Journal of Cosmetic Science, 2002, vol. 24, issue 5, pp. 287-302

[17] Smith, K.J. Colour order systems, colour spaces, colour difference and colour scales. In: McDonald, R. (Eds.), Colour physics for industry (2th Ed.), JSDC, Bradford, England. pp. 121-208 (ISBN 090195670 8), 1997

[18] Tang, R.C., Tang, H., Yang, C. Adsorption Isotherms and Mordant Dyeing Properties of Tea Polyphenols on Wool, Silk, and Nylon. In: Industrial\&Engineering Chemistry Research, 2010, vol. 49, issue 19, pp. 8894-8901

[19] Ke, G., Yu, W., Xu, W. Color Evaluation of Wool Fabric Dyed With Rhizomacoptidis Extract. In: Journal of Applied Polymer Science, 2006, vol. 101, issue 5, pp. $3376-3380$

[20] Sapers, G.M., Taffer, I., Ross, L.R. Functional properties of a food colorant prepared from red cabbage. In: Journal of Food Science, 1981, vol.46,issue.1, pp.105-109

[21] Mazza, G., Brouillard, R. The mechanism of copigmentation of anthocyanins in aqueous solutions. In: Phytochemistry, 1990, vol. 29, issue 4, p. 1097-1102

[22] Malien-Aubert, C., Dangles, O. Amiot, M.J. Color stability of commercial anthocyanin based extracts in relation to the phenolic composition. In: J. Agric. Food Chem., 2001, vol. 49, issue 1, pp. 170-176

[23] Baublis, A., Spomer, A., Berber-Jimenez, M.D. Anthocyanin pigments: comparison of extract stability. In: Journal of Food Science, 1994, vol. 59, issue 6, pp. 1219-1221

[24] ISO 105-C10:2006 Textiles-tests for color fastness - Part C10: color fastness to washing with soap or soap and soda, test Condition: test $A$ (1). Geneva, International Organization for Standardization

[25] ISO 105-B02:1994 Textiles-tests for color fastness, Part B02: color fastness to artificial light. Geneva, International Organization for Standardization

[26] ISO 105-X12:1993 Textiles-tests for color fastness, Part X12: color fastness to rubbing. Geneva, International Organization for Standardization

[27] ISO 105-E04:1994 Textiles-tests for color fastness, Part E04: color fastness to perspiration. Geneva, International Organization for Standardization

\author{
Authors: \\ HÜSEYIN BENLI \\ Mustafa Çıkrıkçıoğlu Vocational School \\ Erciyes University Kayseri, Turkey \\ Corresponding author: \\ HÜSEYIN BENLI \\ hbenli@erciyes.edu.tr
}

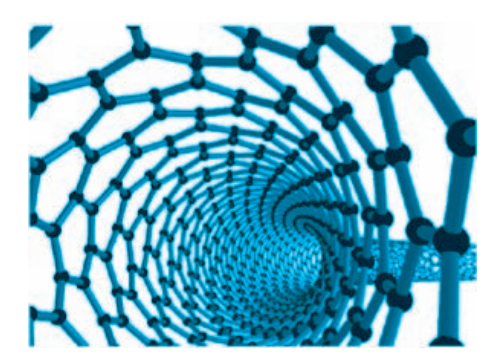




\title{
Water footprint assessment for Chinese textiles
} manufacturing sector

\author{
DOI: 10.35530/IT.068.02.1303
}

\section{REZUMAT - ABSTRACT}

\section{Evaluarea amprentei de apă pentru industria producătoare de textile din China}

Fabricarea industrială a textilelor utilizează o mare cantitate de apă. Industria producătoare de textile este una dintre cele mai mari sectoare consumatoare de apă dulce şi, de asemenea, este una dintre cele mai mari sectoare de evacuare a apelor reziduale din China. Acest studiu are ca scop evaluarea amprentei de apă (WF) din industria producătoare de textile din China şi investigarea factorilor de influență a acestora pe baza metodologiei WF şi identității Kaya. Rezultatele au arătat că amprenta de apă albastră operațională solicitată şi amprenta de apă albastră operațională reală a crescut din 1996 până în 2011, deşi a existat o scădere tranzitorie în 2008. Valoarea de vârf a amprentei de apă albastră operațională solicitată şi a amprentei de apă albastră operațională reală a fost de 10,8 $\mathrm{Gm}^{3}$ /an şi respectiv 7,9 Gm³/an şi a apărut în 2007. Amprenta de apă gri operațională a crescut mai repede şi s-a extins mai mult decât amprenta de apă gri operațională reziduală în intervalul de timp selectat. Productivitatea amprentei de apă a crescut continuu în perioada 1996-2011, în special în perioada cuprinsă între 2007 şi 2011. Extinderea industriei producătoare de textile este factorul determinant în creşterea amprentei de apă albastră operațională şi a amprentei de apă gri operațională reziduală. Diminuarea intensității amprentei de apă este factorul principal inhibat. Efectul de inhibare a îndepărtării poluanților asupra creşterii amprentei de apă gri operațională este mai mare decât cea a reutilizării apei, asupra creşterii amprentei de apă albastră operațională reală.

Cuvinte-cheie: amprentă de apă, industria producătoare de textile, productivitatea amprentei de apă, factori determinant

\section{Water footprint assessment for Chinese textiles manufacturing sector}

The industrial manufacturing of textiles is water intensive. The textiles manufacturing sector is one of the largest freshwater consumption sectors, and also is one of the largest wastewater discharge sectors in China. This study aims at assessing Chinese textiles manufacturing sector's water footprints (WFs) and investigating the influencing factors of them based on WF methodology and Kaya identities. The results showed that the demanded blue operational WF and the actual blue operational WF increased from 1996 to 2011 though there was a transitory decline in 2008. The peak value of demanded blue operational WF and actual blue operational WF was $10.8 \mathrm{Gm}^{3} / \mathrm{yr}$ and $7.9 \mathrm{Gm}^{3} / \mathrm{yr}^{\mathrm{respectively}}$ and appeared in 2007. The original grey operational WF increased faster and much larger than the residuary grey operational WF in the selected temporal interval. WF productivity increased continuously from 1996 to 2011, especially in the period from 2007 to 2011 . The scale enlargement of the textiles manufacturing sector is the promotion factor for the increasing of actual blue operational WF and residuary grey operational WF. The decrease of WF intensity is the main inhibited factor. The inhibiting effect of pollutants removal on the increase of residuary grey operational WF is larger than that of water reuse on the increase of actual blue operational WF.

Keywords: water footprint, textiles manufacturing sector, water footprint productivity, influencing factors

\section{INTRODUCTION}

The industrial manufacturing of textiles is a long and complicated chain. It involves many water intensive processes, such as scouring, dyeing, finishing and washing. Freshwater is used for cleaning and flushing, and generating large quantities of wastewater, causing serious environmental problems. In China, textiles manufacturing sector is an important component of the textile industry. It covers the production cycle from the production of raw materials (natural fibers) to semi-processed (yarn, woven and knitted fabrics, and nonwovens with their finishing processes), and final products (home textiles and industrialuse textiles) according to China's industrial classification for national economic activities (GB/T 4754-2011). Nevertheless, the textiles manufacturing sector is the fifth largest freshwater consumption sec- tor and the third largest wastewater discharge sector among all Chinese manufacturing sectors in recent years. It took approximately 6.2 percent and 10.5 percent shares of all the manufacturing sectors' total freshwater consumption and wastewater discharge in 2014, respectively [1]. Reducing freshwater consumption and wastewater discharge of the textiles manufacturing sector is gaining more and more attention in recent years.

Several tools have recently been developed to promote the water resource management of industrial manufacture of textiles. Water footprint (WF) is one such tool. WF was first introduced by Hoekstra in 2002 [2]. It is a multi-dimensional indicator measuring water resources appropriation by source and polluted volumes by type of pollution. There are three kinds of water (i.e. green water, blue water and grey water) 
according to WF methodology. Green water is rainwater insofar as it does not become run-off. Blue water refers to surface and groundwater. Grey water refers to the freshwater that is required to assimilate the load of pollutants given natural background concentrations and existing ambient water quality standards. WF methodology has gained extensive interest since its introduction as it is a helpful accounting and assessing tool for water resource management research of process steps, products, consumers, businesses and nations [3].

There have been several studies devoted to assess the WF of textile products, processes steps and businesses. Chapagain et al. reported that the global cotton WF at $256 \mathrm{Gm}^{3} / \mathrm{y}$, with a global average of 4264, 4242 , and $622 \mathrm{~m}^{3} / \mathrm{t}$ for green, blue, and grey water, respectively [4]. Mekonnen and Hoekstra estimated that cotton accounts for 3.1 percent of the world's total WF [5]. Chico et al. quantified the WFs of five types of textiles commonly used for the production of jeans [6]. Their research showed that the fiber production is the stage with the highest water consumption. Cellulose-based Lyocell fiber had notably lower water consumption than cotton fibers, on average $1384,34.5$, and $35.3 \mathrm{~m}^{3} / \mathrm{t}$ as opposed to 263,2767 , and $203 \mathrm{~m}^{3} / \mathrm{t}$ for green, blue, and grey water, respectively. Wang et al. calculated the WFs of seven types of knitted fabrics and argued that the majority of the WF was caused by grey WF (WF $\left.F_{\text {grey }}\right)$ [7]. Dyeing had the largest WF among all the processes. Wang et al. thereby also suggested that WF can be largely reduced through wastewater treatment before discharge [8-9].

Generally, there are many factors that influence the WF of a sector, such as scale expansion, new technologies application, water resource management policies implementation and so on. The goal of this paper is to assess Chinese textiles manufacturing sector's WFs and investigate the influencing factors of them. In this paper, we first calculated the WF and water footprint productivity (WFP) of Chinese textiles manufacturing sector from 1996 to 2011. Then, influencing factors of WFs were decomposed based on Kaya identities and quantified by converting all factors to natural logarithmic. The results of this study provide detailed insights into the summary and outlooks of Chinese textiles manufacturing sector's WFs.

\section{METHODOLOGY AND DATA}

\section{Methodology}

Freshwater that directly consumed in the manufacture of textiles mainly includes surface water and groundwater, depends on whether there is a river nearby the factory. These two kinds of water are generally called blue water according to WF methodology. The sector's total WF is the sum of all the WFs of the manufacturing factories. Generally, the WF of a factory consists of two components, operational WF $\left(W F_{\text {oper }}\right)$ and supply chain WF $\left(W F_{\text {sup }}\right)$ [3]. In this paper, we focus on the $W F_{\text {oper }}$ as a factory has direct control over its $W F_{\text {oper }}$. The sector's total blue $W F_{\text {oper }}$ $\left(W F_{\text {oper,blue }}\right)$ can be calculated with a bottom-up approach as follows:

$$
\begin{aligned}
W F_{\text {oper,blue }} & =\sum_{i} W F_{\text {oper,blue }}\left[f_{i}\right]= \\
& =\sum_{i} \text { YearlyFreshwaterInput }\left[f_{i}\right]
\end{aligned}
$$

where $W F_{\text {oper,blue }}\left[f_{i}\right]\left(\mathrm{Gm}^{3} / \mathrm{yr}\right)$ is the $W F_{\text {oper,blue }}$ of textiles manufacturing factory $i$.

$W F_{\text {oper,blue }}\left[f_{i}\right]$ can be calculated based on the yearly statistics of freshwater input. Generally, actual water 'demands' is larger than freshwater 'input' as there is water reuse in a textiles manufacturing factory. Thus, we propose an indicator, $W F_{\text {oper,blue }}^{\text {dema }}$, to represent the actual water 'demands'. It equals the sum of $W F_{\text {oper,blue }}$ and water reuse. The more water reuse, the less freshwater input for a textiles manufacturing factory.

Another important component of WF is $W F_{\text {grey, an }}$ indicator to assess the degree of water pollution. In reality, wastewater that directly generated in textiles industrial manufacturing contains high concentrations of salts, total suspended solids, color, chemical oxygen demand (COD), nutrients (nitrogen and phosphorous) and toxic compounds, such as surfactants, heavy metals, and chlorinated organic compounds [10]. These pollutants can cause serious impacts on the environment. With $W F_{\text {grey }}$, the degree of water pollution is expressed in terms of a volume of needed freshwater, so it can be compared with freshwater consumption. Pretreatment of wastewater before discharge will obviously result in a reduced concentrations of pollutants. Therefore, operational $W F_{\text {grey }}$ $\left(W F_{\text {oper,grey }}\right)$ of a textiles manufacturing factory can be decomposed into original $W F_{\text {oper,grey }}^{\text {ori }}\left(W F_{\text {oper,grey }}\right)$ and residuary $W F_{\text {oper,grey }}\left(W F_{\text {oper,grey }}^{\text {res }}\right)$ [9]. They can be calculated as follows:

$$
\begin{aligned}
W F_{\text {oper,grey }}^{\text {ori }} & =\sum_{i} W F_{\text {oper,grey }}^{\text {ori }}\left[f_{i}\right]= \\
& =\sum_{i}\left(\max \left(\frac{L_{\text {oper,ori }}^{k}}{c_{\text {max }}^{k}-c_{\text {nat }}^{k}}\right)\right)\left[f_{i}\right] \\
W F_{\text {oper,grey }}^{\text {res }} & =\sum_{i} W F_{\text {oper,grey }}^{\text {res }}\left[f_{i}\right]= \\
& =\sum_{i}\left(\max \left(\frac{L_{\text {oper,res }}^{k}}{c_{\text {max }}^{k}-c_{\text {nat }}^{k}}\right)\right)\left[f_{i}\right]
\end{aligned}
$$

where $L_{\text {oper,ori }}^{k}(\mathrm{t} / \mathrm{yr})$ is the original load of pollutant $k$ directly generated in manufacturing factory $i$. $c_{\text {max }}^{k}$ $(\mathrm{mg} / \mathrm{l})$ is the maximum acceptable concentration of pollutant $k$ that can be discharged. $c_{n a t}^{k}(\mathrm{mg} / \mathrm{l})$ is the natural concentration of pollutant $k$ in the receiving water body. $L_{\text {oper,res }}^{k}(\mathrm{t} / \mathrm{yr})$ is the residuary load of pollutant $k$ after treatment and discharged to natural water bodies. max means $W F_{\text {oper,grey }}^{\text {ori }}$ and $W F_{\text {oper,grey }}^{\text {res }}$ are determined by the most critical pollutant that is 
associated with the largest pollutant-specific WF oper,grey.

Besides the quantifying of WF, assessing the economic sustainability of WF also is very important. Thus we propose water footprint productivity (WFP, US dollar $/ \mathrm{m}^{3}$, i.e. economic output per volume of water resources appropriation) as the economic indicator. It can be calculated as follows:

$$
W F P=\frac{T I O V}{W F}
$$

where TIOV (billion US dollars/yr) is the total industrial output value of the textile manufacturing sector. It is the sector's aggregate data calculated with collected terminal factories output data.

In order to give a full scene of the influencing factors of Chinese textiles manufacturing sector's WFs, equation (1) and equation (3) can be further expressed as follows:

$$
\begin{aligned}
W F_{\text {oper,blue }} & =\operatorname{TIOV} \times \frac{W F_{\text {oper,blue }}^{\text {dema }}}{\text { TIOV }} \times \frac{W F_{\text {oper,blue }}^{\text {dema }}}{W F_{\text {oper,blue }}^{\text {dem }}}= \\
& =E \times I_{\text {blue }} \times R_{\text {blue }}^{\text {res }} \\
W F_{\text {oper,grey }} & =T I O V \times \frac{W F_{\text {oper,grey }}^{\text {ori }}}{T I O V} \times \frac{W F_{\text {oper,grey }}^{\text {res }}}{W F_{\text {oper,grey }}^{\text {ori }}}= \\
& =E \times I_{\text {grey }} \times R_{\text {grey }}
\end{aligned}
$$

where $E$ represents the economic output. $I_{\text {blue }}$ represents the blue WF intensity. $R_{\text {blue }}$ represents the water reuse rate. $I_{\text {grey }}$ represents the grey WF intensity. $R_{\text {grey }}$ represents the pollutants removal rate. Then, all factors in equation (5) and equation (6) can be converted to natural logarithmic form as follows:

$$
\begin{aligned}
& \operatorname{In} W F_{\text {oper,blue }}=\ln E+\ln I_{\text {blue }}+\ln R_{\text {blue }}+\varepsilon \\
& \ln W F_{\text {oper,grey }}^{\text {res }}=\ln E+\ln I_{\text {grey }}+\ln R_{\text {grey }}+\varepsilon
\end{aligned}
$$

where $\varepsilon$ is the normally distributed error term.

\section{Data}

Annual Statistic Report on Environment in China releases sectors' yearly industrial environmental data (include freshwater input, water reuse, water pollutants and wastewater discharge) collected from terminal factories [11]. We directly used these aggregate data for WF calculation. The economic data were collected from the annual China Statistical Yearbook [12]. COD was generally the most critical pollutant according to former researches, therefore we selected $\mathrm{COD}_{\mathrm{Cr}}$ for the calculation of $W F_{\text {oper,grey }}$ [7-9]. The maximum acceptable concentration of $\mathrm{COD}_{\mathrm{Cr}}$ was $100 \mathrm{mg} / \mathrm{l}$ according to the national standard GB 4287 Discharge Standard of Water Pollutants for Dyeing and Finishing of Textile Industry.

\section{RESULTS AND DISCUSSION}

$W F_{\text {oper,blue }}^{\text {dema }}$ and $W F_{\text {oper,blue }}$ of the textiles manufacturing sector were calculated and the results are shown in figure 1. It can be seen that there was a slight decrease for the two indicators from 1996 to 1999. They increased continually from 2000 and reached the peak values $\left(10.8 \mathrm{Gm}^{3} / \mathrm{yr}\right.$ and $7.9 \mathrm{Gm}^{3} / \mathrm{yr}$ ) in 2007. The average increasing rates were 15.5 percent and 19.3 percent, respectively. Then, there was a rapid decline in 2008. $W F_{\text {oper,blue }}^{\text {dema }}$ reduced to 8.3 $\mathrm{Gm}^{3} / \mathrm{yr}$ and $W F_{\text {oper,blue }}$ reduced to $6.2 \mathrm{Gm}^{3} / \mathrm{yr}$. They regained increase trend from 2009 though there was a slight decrease in 2011. The difference value between $W F_{\text {oper,blue }}$ and $W F_{\text {oper,blue }}$, the quantity of water reuse, had little fluctuation from 1996 to 2011.

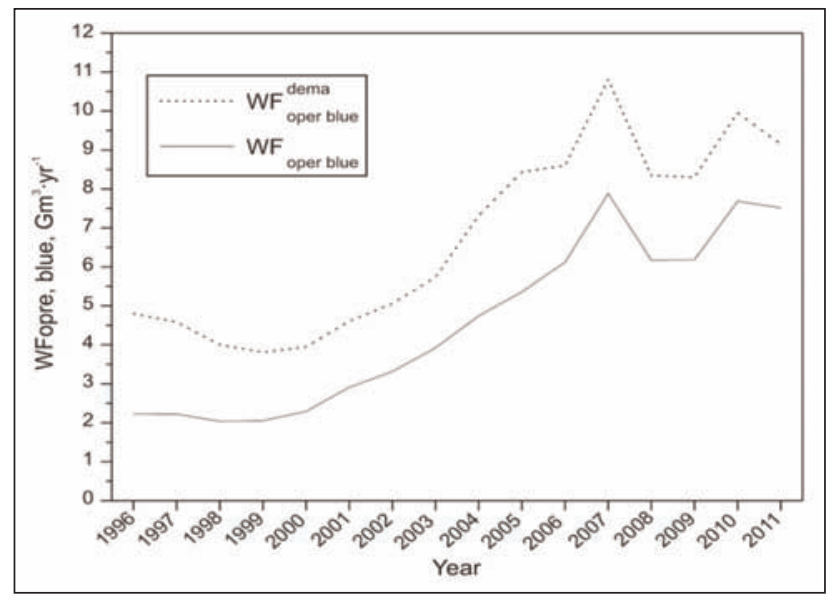

Fig. 1. $W F_{\text {oper,blue }}^{\text {dema }}$ and $W F_{\text {oper,blue }}$ of the textiles manufacturing sector

Figure 2 shows $W F_{\text {oper,grey }}^{\text {ori }}$ and $W F_{\text {oper,grey }}^{\text {res }}$ of the textiles manufacturing sector from 1996 to 2011. Generally, $c_{n a t}$ is assumed equal to zero for simplicity. Thus $W F_{\text {oper,grey }}^{\text {ori }}$ and $W F_{\text {oper,grey }}^{\text {res }}$ were underestimated according to equations (2) and equations (3) as $c_{\text {nat }}^{C O D C r}$ is actually not equal to zero [3]. WFori increased more than five times in the selected temporal interval though there was a staged decrease in 2008. $W F_{\text {oper,grey }}^{\text {res }}$ increased much less, approximately one time, compared to WFoper,grey from 1996 to 2011. The peak value appeared in 2010 with a value of $10.5 \mathrm{Gm}^{3} / \mathrm{yr}$. The difference value between $W F_{\text {oper,grey }}^{\text {ori }}$ and $W F_{\text {oper,grey }}^{\text {res increased continuously in }}$ this period.

From figure 3 it can be seen that WFP oper,blue and $W F P_{\text {oper,grey }}^{\text {res }}$ of the textiles manufacturing sector had similar evolution trends from 1996 to 2011. There were slight increases for $W F P_{\text {oper,blue }}$ and $W F P_{\text {oper,grey }}^{\text {res }}$ from 1996 to 2007 . Then, they increased fast from 2007 to 2011, with an increase of approximately 79.1 percent and 137.1 percent, respectively. WFP oper,blue was larger than WFP oper,grey and the difference value between them decreased year by year. 


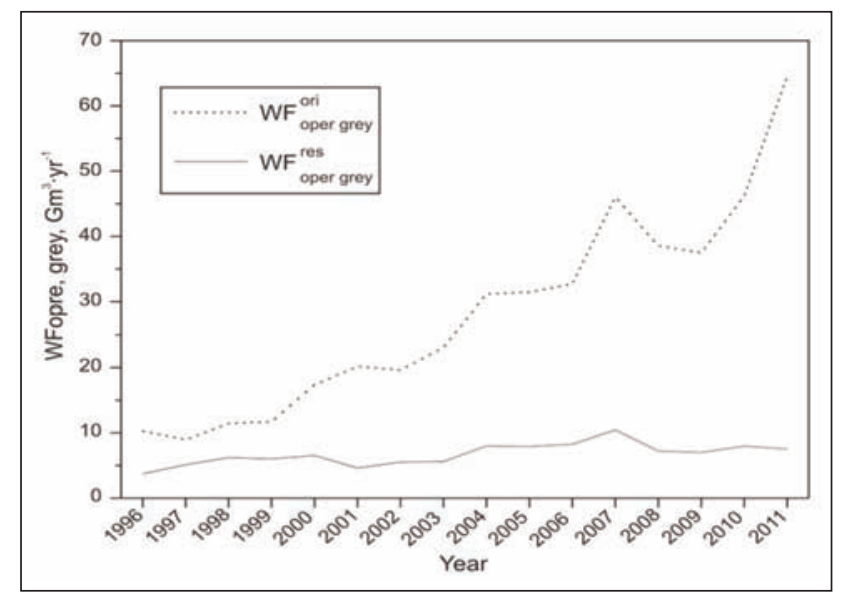

Fig. 2. $W F_{\text {oper,grey }}^{\text {ori }}$ and $W F_{\text {oper,grey }}^{\text {res }}$ of the textiles manufacturing sector

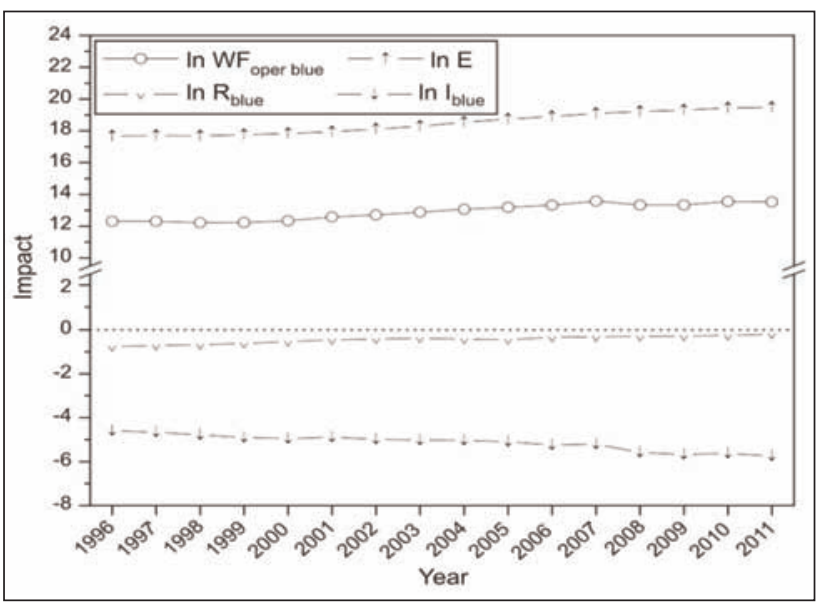

Fig. 4. Influencing factors of $W F_{\text {oper,blue }}$

With the faster development of textiles manufacturing industry, China has been the world's largest producer and exporter of textiles for many years. The textiles manufacture sector provides quantities of natural fiber, yarns, fabrics and final products every year. Therefore, large quantities of freshwater are consumed for cleaning, flushing and as solvent. As a result, quantities of textile effluents are generated and discharged. As one of the important freshwater consumption and wastewater discharge sectors, many policies and new technologies have been applied to restrict and reduce freshwater consumption, wastewater generation and discharge.

Figure 4 and figure 5 show the influencing factors of Chinese textiles manufacturing sector's WF oper,blue

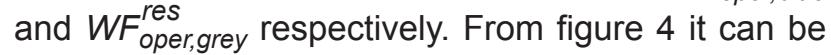
seen that the scale enlargement of the textiles manufacturing sector (i.e. the increase of the economic output) is the only promotion factor for the increase of $W F_{\text {oper,blue }}$. The application of water saving technologies, promoting the decrease of $W F_{\text {oper,blue }}$ intensity (i.e. the reciprocal of $W F_{\text {oper,blue }}$ ), is the main inhibited factor for the increase of $W F_{\text {oper,blue. Reuse water }}$

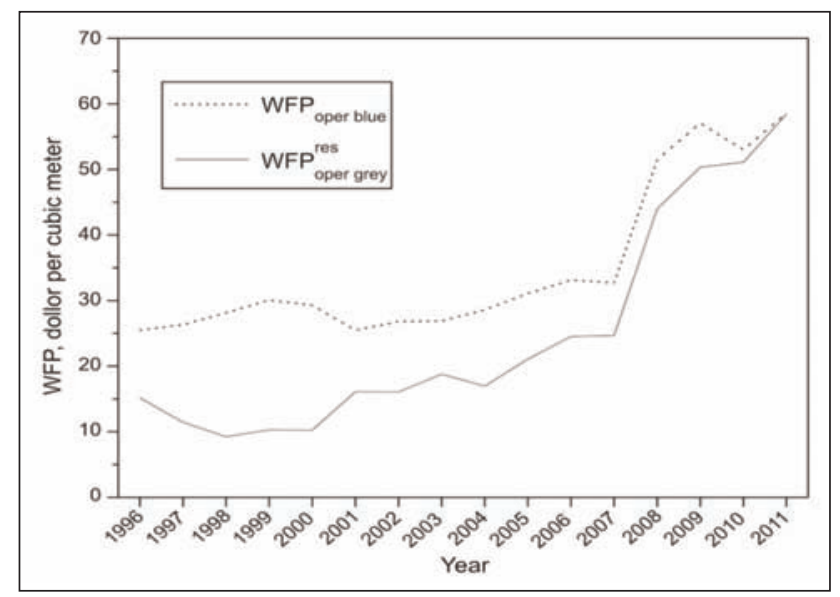

Fig. 3. $W F P_{\text {oper,blue }}$ and $W F P_{\text {oper,grey }}^{\text {res }}$ of the textiles manufacturing sector

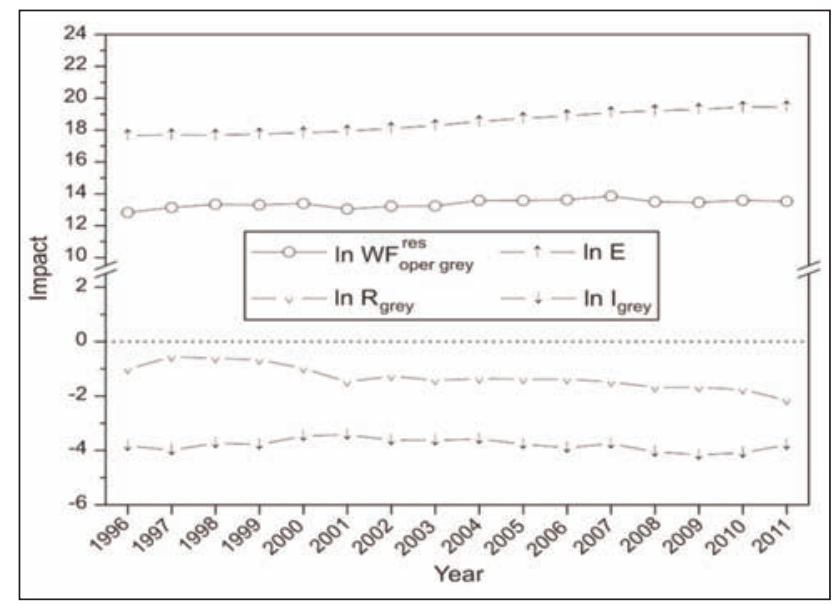

Fig. 5. Influencing factors of $W F P_{o p e r, g r e y}^{\text {res }}$

can substitute freshwater and further reduce $W F_{\text {oper,blue. }}$ However, the water reuse rate decreased (figure 1) from 1996 to 2011.

The inhibiting effect of water reuse on the increase of $W F_{\text {oper,blue }}$ weakened gradually.

The effects of influencing factors of $W F_{\text {oper,grey }}^{\text {res }}$ are similar to that of $W F_{\text {oper,blue. Pretreatment is very }}$ important for originally generated textile effluents before they are discharged into receiving water bodies. It can reduce $W F_{\text {oper,grey }}$ remarkably (see figure 2). The inhibiting effect of pollutants removal on the increase of WF res 2011.

\section{CONCLUSION}

This paper presents an analysis of $W F_{\text {oper,blue, }}$ $W F_{\text {oper,grey, }}$ WFP and the influencing factors of WFs of the Chinese textiles manufacturing sector. $W F_{\text {oper,blue }}^{\text {dema }}$ and $W F_{\text {oper,blue }}$ showed an increasing trend from 1996 to 2011 though there was a transitory decline in 2008. The peak value of $W F_{o p e r, b l u e}^{\text {dema }}$ and $W F_{\text {oper,blue }}$ was $10.8 \mathrm{Gm}^{3} / \mathrm{yr}$ and $7.9 \mathrm{Gm}^{3} / \mathrm{yr}$ respectively and appeared in 2007. WF ori 
faster and much larger than $W F_{\text {oper,grey }}^{\text {res }}$ in the select ed temporal interval. WFP oper,blue and $W F_{\text {oper, grey }}^{\text {res }}$ increased continuously from 1996 to 2011, especially in the period from 2007 to 2011.

The scale enlargement of the textiles manufacturing sector is the only promotion factor for the increasing of $W F_{\text {oper,blue }}$ and $W F_{\text {oper,grey }}^{\text {res }}$ The decrease of WF intensity is the main inhibited factor. The inhibiting effect of pollutants removal $\left(R_{\text {grey }}\right)$ on the increase of $W F_{\text {oper,grey }}^{\text {res }}$ is larger than that of water reuse $\left(R_{\text {blue }}\right)$ on the increase of $W F_{\text {oper,blue }}$.

Water footprint assessment is meaningful for water management in the textiles manufacturing sector. It can promote the reasonable use of freshwater and restriction of wastewater generation and discharge.
This paper gives a general overview of the WFs of the textiles manufacturing sector and the influencing factors of WFs. Nevertheless, more attention should also be paid on the assessment of WFs of textiles products and manufacturing technologies in the future.

\section{ACKNOWLEDGEMENTS}

The authors are grateful to the National Natural Science Foundation of China for providing funding supports to this research through project 71503233 , to Zhejiang Sci-Tech University for providing funding supports to this research through project "Zhejiang Sci-Tech University Scientific Research Foundation (15072022-Y)" and "Zhejiang Top Priority Discipline of Textile Science and Engineering (2013YBZX03)".

\section{BIBLIOGRAPHY}

[1] Ministry of Environmental Protection of the People's Republic of China, Environment statistical yearbook in 2014, 2016. http://zls.mep.gov.cn/hjtj/nb/2014tjnb/

[2] Hoekstra, A. Y., Virtual water trade: proceedings of the international expert meeting on virtual water trade, In: Value of Water Research Report Series No.12, UNESCO-IHE, Delft, The Netherlands, 2003.

[3] Hoekstra, A. Y., Chapagain, A. K., Aldaya, M. M., Mekonnen, M. M, The water footprint assessment manual: Setting the global standard, In: Earthscan, London, UK, 2011.

[4] Chapagain, A. K., Hoekstra, A. Y., Savenije, H. H. G., Gauta, R. The water footprint of cotton consumption: An assessment of the impact of worldwide consumption of cotton products on the water resources in the cotton producing countries. In: Ecological Economics, 2006, vol. 60, issue 1, p. 186.

[5] Mekonnen, M. M., Hoekstra, A. Y. The green, blue and grey water footprint of crops and derived crop products. In: Hydrology and Earth System Sciences, 2011, vol. 15, issue 5, p. 1577.

[6] Chico, D., Aldaya, M. M., Garrido, A. A water footprint assessment of a pair of jeans: the influence of agricultural policies on the sustainability of consumer products. In: Journal of Cleaner Production, 2013, vol. 57, issue 1, p. 238.

[7] Wang, L. L., Ding, X. M., Wu, X. Y., Yu. J. M. Textiles industrial water footprint: methodology and study. In: Journal of Scientific \& Industrial Research, 2013, vol. 72, issue 11. p.710.

[8] Wang L. L., Ding X. M., Wu X. Y., Ndwiga D. K. The introduction of water footprint methodology into the textile industry. In: Industria Textila, 2014, vol. 65, issue 1, p. 33.

[9] Wang L. L., Ding X. M., Wu X. Y. Blue and grey water footprint of textile industry in China. In: Water Science \& Technology, 2013, vol. 68, issue 11, p. 2485.

[10] Ergas, S. J., Therriault, M. A., Reckhow, D. A., Asce, M. Evaluation of water reuse technologies for the textile industry. In: Journal of Environmental Engineering, 2006, vol. 132, issue. 3, p. 315.

[11] Ministry of Environmental Protection of the People's Republic of China. Annual Statistic Report on Environment in China, China Environmental Science Press, Beijing, China, 1997-2012.

[12] National Bureau of Statistics of China. China Statistical Yearbook, China Statistics Press, Beijing, China, 1997-2012.

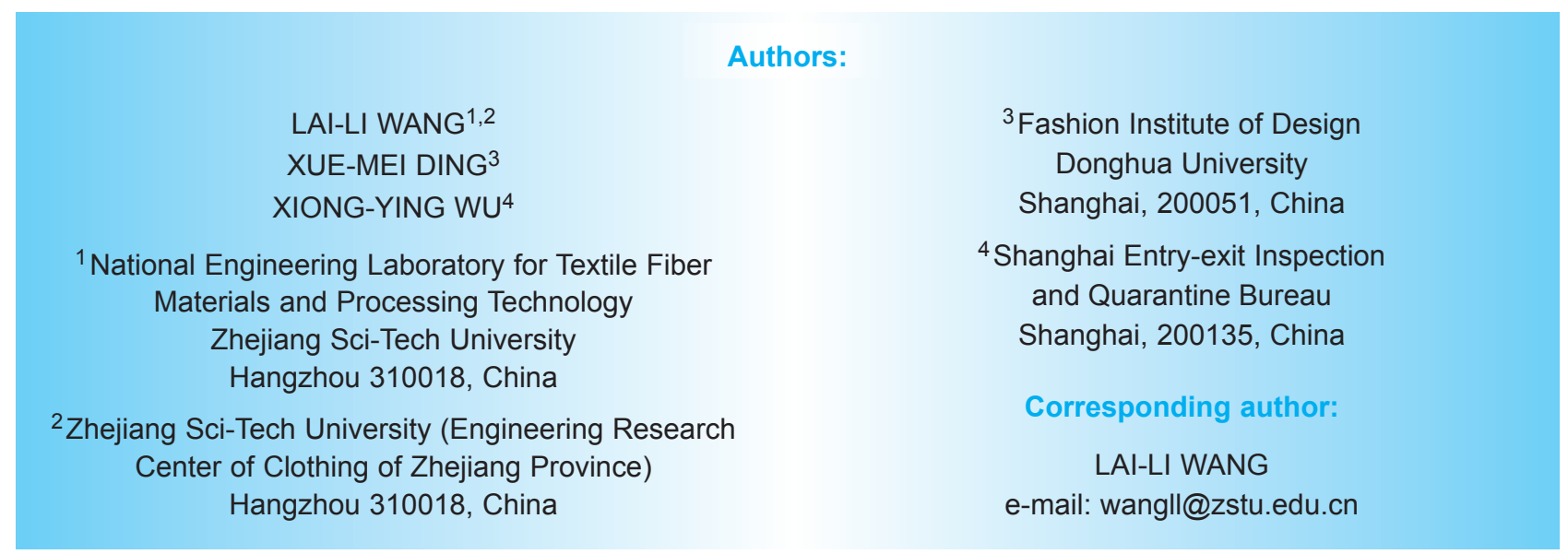




\title{
Dependence of dry, wet and washing relaxation on knitted structures and fabric parameters
}

\author{
DOI: $10.35530 / I T .068 .02 .1333$
}

\author{
ELEONORA GSELL \\ FRANK HEIMLICH
}

ANDREA EHRMANN

MARCUS O. WEBER

\section{REZUMAT - ABSTRACT}

\section{Dependența relaxării în stare uscată, umedă și la spălare de structura materialelor tricotate} şi parametrii produsului

\begin{abstract}
Înțelegerea proceselor de relaxare a materialelor tricotate are o mare importanță pentru companiile de tricotaje, precum și în cercetarea de bază. Acest articol analizează noua abordare a proceselor de relaxare prin raportare la numărul de ochiuri, ochiuri duble și bucle din structurile tricotate din bătătură, arătând că în special numărul de ochiuri duble influențează puternic comportamentul de relaxare și descrie corelarea proceselor de relaxare cu factorul de acoperire și desimea ochiurilor. Cuvinte-cheie: material tricotat, relaxare în stare uscată, relaxare în stare umedă, relaxare la spălare, structură tricotată,
factor de acoperire, desimea ochiurilor
\end{abstract}

\section{Dependence of dry, wet and washing relaxation on knitted structures and fabric parameters}

Understanding the relaxation processes of knitted fabrics is of importance for knitting companies as well as in basic research. This article examines the new approach of relating the relaxation processes to the percentages of stitches, tucks, and floats in weft knitted structures, showing that especially the number of tucks strongly influences the relaxation behavior, and depicts the correlation of the relaxation processes with the cover factor and the stitch density.

Keywords: knitted fabric, dry relaxation, wet relaxation, washing relaxation, knitted structure, cover factor, stitch density

\section{INTRODUCTION}

Due to the necessity that dimensional changes must either be taken into account for tailoring or finishing a fabric to the expected dimensions, the knowledge of relaxation processes is important for knitted garments producers. Many research groups thus deal with theoretical descriptions of relaxation processes for different materials and structures or show experimental results for the changes in fabric width and height [1-19].

In both experimental and theoretical works, inconsistent results are found, depending on the experimental parameters: Full relaxation, e.g., has been reported to appear after one or after ten washing cycles for silk knitted fabrics [16, 20]. For wool knitted fabrics, full relaxation is reported to be reached after wetting and tumble drying for one hour or after ten washing and tumble dry cycles [9, 13]. For polyester (PES) and PES/stainless steel fiber yarns, recent experiments have shown that a fully relaxed state cannot always be reached [7, 11]. These different findings are not explained in the respective articles. Possible reasons are different yarn-yarn friction resulting in energy barriers of different heights which have to be overcome during relaxation, so that different amounts of energy are necessary for further relaxation steps; different bending stiffness of the yarns under examination, supporting the relaxation more or less; or other yarn or fabric parameters. Similarly, the results of dry, wet, and washing relaxation are strongly dependent on fabric and machine parameters due to the above mentioned possible reasons.

None of the above mentioned literature concentrates explicitly on the influence of the three structure elements stitch, tuck, and float. Usually, only one or a few different structures are examined in one experiment; comparisons to other research groups' results are normally impossible due to the inconsistency of other yarn and machine parameters.

This article aims at correlating relaxation processes with general structure parameters, such as stitch, tuck, and float percentages in different knitted structures, cover factor and stitch densities as well, in order to find some general rules on the explanation of relaxation processes qualitatively and quantitatively with respect to the three basic structure elements.

\section{EXPERIMENTAL}

Fabrics were knitted on a flat knitting machine CMS 340 TC-KW (Stoll) with a machine gauge of E6.2 (stitch cam setting NP = 12.0, carriage speed $70 \mathrm{~cm} / \mathrm{s}$, one feeder, knitting width of needle bed $0.5 \mathrm{~m}$ ) using a yarn consisting of $50 \%$ cotton and $50 \%$ polyacrylonitrile (Nm 30/2).

The knitted structures used for this project are depicted in figure 1, together with the relative amount of stitches, tucks, and floats. Each samples was knitted once. 


\begin{tabular}{|c|c|c|c|c|}
\hline 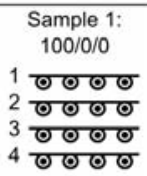 & 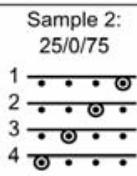 & 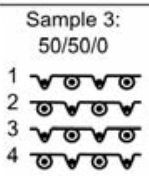 & 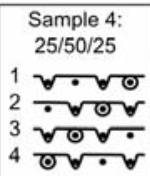 & 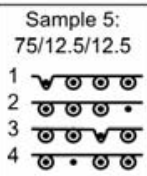 \\
\hline 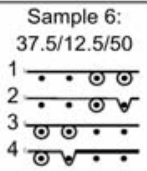 & 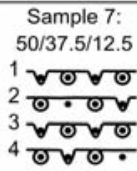 & 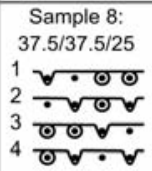 & 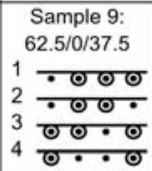 & 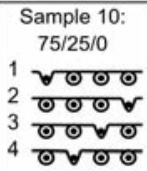 \\
\hline 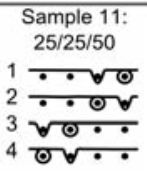 & & 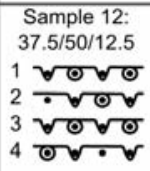 & & 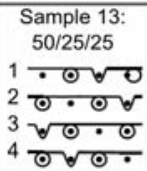 \\
\hline
\end{tabular}

Fig. 1. Knitted fabrics under examination with the percentage of stitch/tuck/float

The lateral dimensions of the knitted fabric - width and height - were measured at three different positions (in the middle as well as between the middle and both borders) on each fabric using a ruler. The first measurements were done directly after taking the fabrics out of the knitting machine, i.e. as soon as the respective sample had left the takedown.

For dry relaxation, measurements were taken ( 1 day \pm 2 hours) after taking the fabric from the knitting machine and second measurements were taken (30 days \pm 3 hours) after knitting, respectively. Then the fabrics were left laid on a flat, smooth surface for relaxation and were gently moved once a week to overcome possible energy barriers due to friction between fabric and surface.

For wet relaxation, the fabrics were laid in water (room temperature) for 12 hours. Afterwards they were spread on a flat, smooth surface and dried for min. 24 hours, before their lateral dimensions were measured.

For washing relaxation, the knitted fabrics were machine washed once using the specified amount of heavy-duty detergent (i.e. bleach-containing laundry detergent) without softener at $30^{\circ} \mathrm{C}$, with a subsequent spin cycle at $1200 \mathrm{~min}^{-1}$. The samples were dried on a flat, smooth surface at room temperature for min. 24 hours before measurements.

In addition to the measurements, microscopic pictures of the knitted fabrics were taken using a VHX600D microscope by Keyence with a VH-Z20R objective and nominally 20 times magnification. These pictures were used to count the stitch and wale densities, using the measurement option of the calibrated microscope. The cover factors were calculated using these microscopic images. The cover factor is defined as the extent to which the areas of the knitted fabrics are covered by the yarn. For this, microscopic pictures were transferred into monochrome images, and the relative amounts of black areas covered with yarn were calculated, using the histogram option of CorelDraw ${ }^{\circledR}$. This optical evaluation according to the definition of the cover factor can be expected to be more reliable than the practical expression for the cover factor defined by Munden which is used if the optical examination of the real cover factor is not possible [21-23].

\section{RESULTS AND DISCUSSION}

Table 1 shows the parameters of the knitted fabrics, determined using microscopic pictures taken after the knitting process. As visible in the table, the stitch and wale densities show a much broader spectrum of possible values than the cover factor; this is why the relaxation results are depicted as a function of cover factor and stitch density, too.

Table 1

\begin{tabular}{|c|c|c|c|c|}
\hline $\begin{array}{c}\text { Sample } \\
\text { number }\end{array}$ & $\begin{array}{c}\text { Wales I } \\
\mathbf{c m}\end{array}$ & $\begin{array}{c}\text { Courses } / \\
\mathbf{c m}\end{array}$ & $\begin{array}{c}\text { Stitch } \\
\text { density I } \\
\mathbf{c m}^{\mathbf{2}}\end{array}$ & $\begin{array}{c}\text { Cover } \\
\text { factor }\end{array}$ \\
\hline 1 & 6 & 6.5 & 39 & 0.74 \\
\hline 2 & 7 & 5.5 & 38.5 & 0.79 \\
\hline 3 & 4 & 6 & 24 & 0.78 \\
\hline 4 & 4.5 & 4 & 18 & 0.70 \\
\hline 5 & 5.5 & 7 & 38.5 & 0.76 \\
\hline 6 & 5 & 5 & 25 & 0.72 \\
\hline 7 & 5 & 6 & 30 & 0.72 \\
\hline 8 & 4 & 4 & 16 & 0.75 \\
\hline 9 & 6.5 & 5 & 32.5 & 0.80 \\
\hline 10 & 5 & 6.5 & 32.5 & 0.70 \\
\hline 11 & 6 & 4 & 24 & 0.74 \\
\hline 12 & 4.5 & 3 & 13.5 & 0.69 \\
\hline 13 & 6 & 4.5 & 27 & 0.75 \\
\hline
\end{tabular}

Figure 2 depicts the lateral dimensions of the samples under investigation directly after knitting, after one day and one month of dry relaxation, after wet and finally after washing relaxation. Since a former project using different yarn and a circular knitting process has revealed the idea of the percentage of tucks being most important for the dimensional changes in all relaxation processes, the samples are sorted by the relative amounts of tucks [24].

While the fabric length decreases for all samples, samples with relatively high percentage of tucks ( $50 \%$ or $37.5 \%$ ) become wider, while samples with lower amounts of tucks (12.5\% or $0 \%)$ decrease in width. This finding can be explained by the reduction of bending energy in tucks if the yarns forming tucks are oriented more linear, forcing the fabric to become wider. This effect of tucks is also visible in the absolute fabric widths which tend to be higher for higher amounts of tucks.

Figure 3 depicts the measured maximum relaxation in terms of length and width changes, respectively, as a function of the percentage of tucks and stitches. The change in relative length is the smallest $(\sim 12 \%$ shrinkage) for knitted fabrics without tucks, largest for knitted fabrics with $50 \%$ tucks ( $30 \%$ shrinkage) and seems to be independent of the amount of stitches. A broadening of the fabrics occurs for large percentages of tucks ( $\sim 16 \%$ widening), and the strongest 

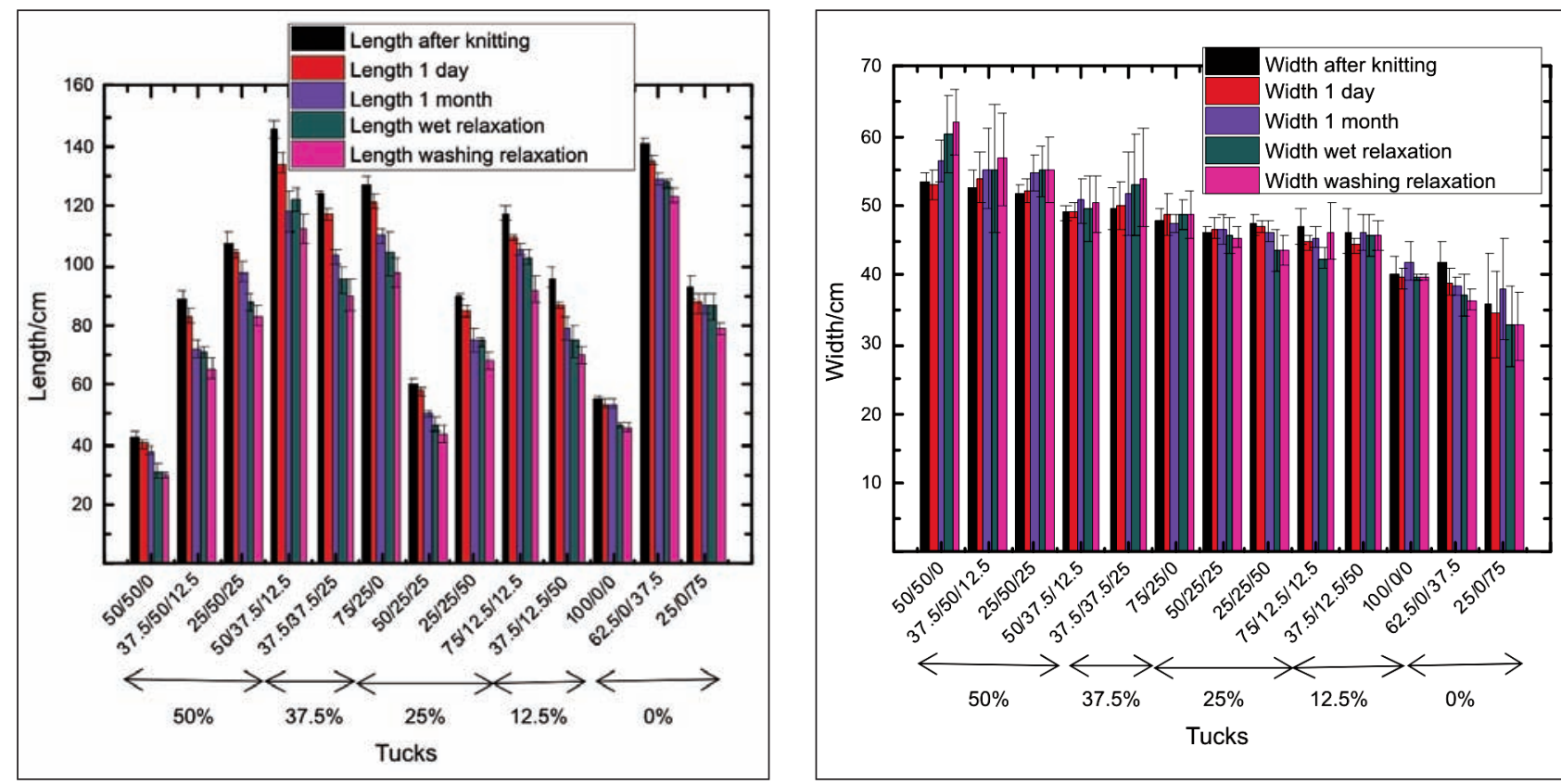

Fig. 2. Change of knitted fabric lengths (upper panel) and widths (lower panel) from the state directly after knitting to dry, wet, and washing relaxation
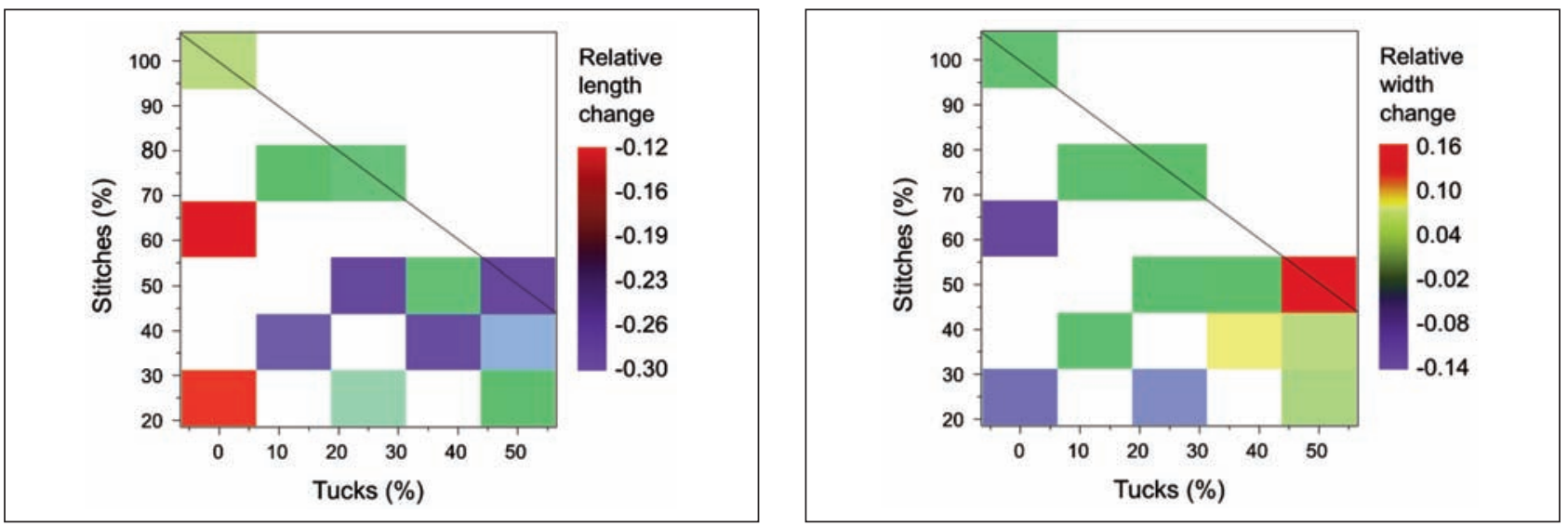

Fig. 3. Change in knitted fabric lengths (left panel) and widths (right panel) for different relaxation states as a function of the numbers of tucks and stitches. The percentaged numbers of floats can be calculated as $(100 \%$ - tucks (\%) - stitches (\%)

narrowing is visible for structures without tucks and with only few stitches ( $14 \%$ narrowing).

In order to test a possible correlation between the dimensional changes during relaxation processes on the one hand and cover factor or stitch density on the other hand, figure 4 shows the relative changes of fabric widths and heights from the as-knitted to the wash-relaxed state as functions of the cover factor. Figure 4 shows again that the length is always decreased during relaxation; however, there is no trend visible how the cover factor may influence the relative dimensional changes. Opposite to former results of other research groups, no clear correlation between dimensional changes and the cover factor can be recognized [22].

In figure 5, the relative changes of fabric widths and heights are depicted as functions of the stitch density. Obviously the relative dimensional changes are not correlated with the stitch density either. However, it should be mentioned that knitting the same structure with different stitch cam settings to create different

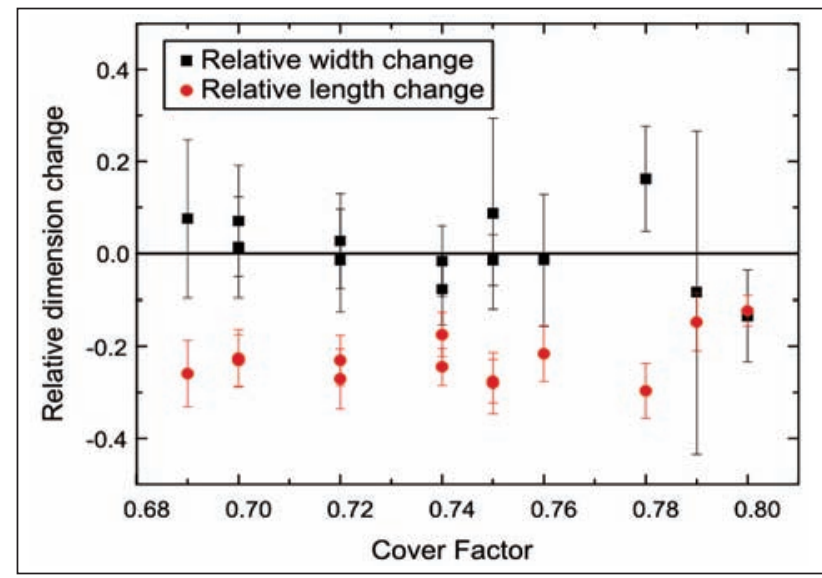

Fig. 4. Change of knitted fabric lengths and widths in different relaxation states as a function of the cover factor 


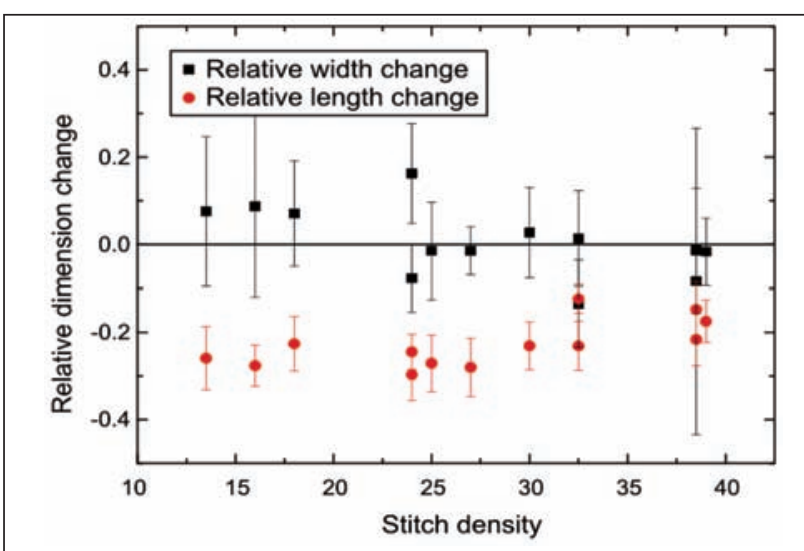

Fig. 5. Change of knitted fabric lengths and widths in different relaxation states as a function of the stitch density

stitch densities may result in a correlation between relative dimensional changes and stitch density for identical structures.

\section{CONCLUSIONS AND OUTLOOK}

From the experiments performed in this study, we can conclude that the dimensional changes of knitted fabrics due to relaxation processes depend strongly on the knitted structure, with the percentages of tucks and stitches influencing the changes of fabric widths and heights. The strong influence of the relative amount of tucks can be explained as followed: the bending stiffness of the yarns forces the tucks to be oriented more linear, resulting in the fabric becoming wider. This process cannot occur in stitches which are bound on both sides; thus the influence of stitches on broadening can be expected to be more complicated. Whether the energy minimum is reached for stitches being as high or as broad as possible probably depends on different parameters, such as the bending stiffness, yarn-yarn friction etc. In floats, however, the yarn is not bent, so that they can be assumed to not influence broadening or narrowing of a knitted fabric. Experiments with circular knitted fabric from polyester have shown qualitatively similar results, this is why the major influence of tucks on broadening during relaxation can be imagined to be a universal behavior [24].

Opposite to former experiments of other groups, our results do not support the idea of a correlation between the lateral changes and the cover factor or the stitch density.

In future examinations, additional structures and materials will be tested to identify the influence of the positions of stitches, tucks and floats in different knitted structures created with identical percentages of these elements.

This research received no specific grant from any funding agency in the public, commercial, or not-forprofit sectors.

\section{BIBLIOGRAPHY}

[1] Herath C.N., Kang B.C., Park S.W., Effect of laundering on the structural and dimensional behavior of core spun cotton/spandex interlock structures, Proc. of the 44th Congress IFKT, St. Petersburg, 2008

[2] Knapton J.J.F., Truter E.V., Aziz A.K.M.A., The geometry, dimensional properties, and stabilization of the cotton plain-jersey structure, In: J. Textile Inst., 66, nr. 12, 1975, pp. 413-419

[3] Kurbak A., Geometrical models for balanced rib knitted fabrics. Part l: Conventionally knitted $1 \times 1$ rib fabrics, In: Text. Res. J., 79, 2009, pp. 418-435

[4] Munden D.L., The geometry and dimensional properties of plain-knit fabrics. In: J. Textile Inst., 50, 1959, pp. 458-471

[5] Perepelkin K.E., Belonogova M.N., Smirnova N.A., Determination of shrinkage of textiles made of chemical and flax fibres by different methods, In: Fibre Chem., 29, nr. 3, 1997, pp. 200-205

[6] Spencer D.J., Knitting technology - a comprehensive handbook and practical guide, Third Ed., Woodhead Publishing Limited and Technomic Publishing Company Inc., Cambridge, 2001

[7] Ehrmann née Tillmanns A., Heimlich F., Brücken A., Weber M.O., Blachowicz T., Experimental investigation of the washing relaxation of knitted fabrics from polyester yarn with stainless steel fibres, In: Fibres \& Textiles in Eastern Europe, 20, nr. 1, 2012, pp. 90-93

[8] Amreeva G., Kurbak A., Experimental studies on the dimensional properties of half milano and milano rib fabrics, In: Text. Res. J., 77, nr. 3, 2007, pp. 151-160

[9] Chen Q.H., Au K.F., Yuen C.W.M., Yeung K.W. Dimensional stability of plain wool knits. In: Textile Asia, 31, nr. 8, 2000, pp. 51-57

[10] Ehrmann A., Blachowicz T., Domino K., Aumann S., Weber M.O., Zghidi H., Examination of hairiness changes due to washing in knitted fabrics using a random walk approach, In: Text. Res. J., 85, 2015, pp. 2147-2154

[11] Ehrmann A., Blachowicz T., Heimlich F., Brücken A., Weber M.O., Influence of the sample dimension and yarn type on the washing relaxation process of knitted fabrics, In: Tekstil, 63, nr. 5-6, 2014, pp. 163-167

[12] Emirhanova N., Kavusturan Y., Effects of knit structure on the dimensional and physical properties of winter outerwear knitted fabrics, In: Fibres \& Textiles in Eastern Europe, 16, 2008, pp. 69-74 
[13] Knapton J.J.F., Ahrens F.J., Ingenthron W.W., Fong W., The dimensional properties of knitted wool fabrics, Part I: The plain-knitted structure. In: Text. Res. J., 38, nr. 10, 1968, pp. 999-1012

[14] Mikučionienè D., Laureckienè G., The Influence of drying conditions on dimensional stability of cotton weft knitted fabrics, In: Mater. Sci., 15, 2009, pp. 64-68

[15] Postle R., Dimensional stability of plain-knitted fabrics, In: J. Textile Inst., 59, nr. 2, 1968, pp. 65-77

[16] Quaynor L., Nakajima M., Takahashi M., Dimensional changes in knitted silk and cotton fabrics with laundering, In: Text. Res. J., 69, nr. 4, 1999, pp. 285-291

[17] Quaynor L., Takahashi M., Nakajima M., Effects of laundering on the surface properties and dimensional stability of plain knitted fabrics, In: Text. Res. J., 70, nr. 1, 2000, pp. 28-35

[18] Tezel S., Kavusturan Y., The influence of relaxation process on dimensional properties of cotton/spandex knitted fabric, magic world of textiles, In: ITC \& DC, 4, 2008, pp. 281-286

[19] Ucar N., Karakas H.C., Effect of lyocell blend yarn and pile type on the properties of pile loop knit fabrics. In: Text. Res. J., 75, nr. 4, 2005, pp. 352-356

[20] Quaynor L., Takahashi M., Nakajima M., Effects of laundering on bending properties of plain-knitted fabrics, In: J. Text. Mach. Soc. Japan (English Ed.), 44, nr. 4, 1998, pp. 74-77

[21] Munden D. L., Specification of construction of knitted fabrics, In: J. Textile Inst., 53, 1962, pp. P628-P630

[22] Gravas E., Kiekens P., van Langenhove L., Predicting fabric weight per unit area of single- and double-knitted structures using appropriate software, In: AUTEX Research Journal, 6, nr. 4, 2006, pp. 223-237

[23] Tamoue F., Weber M.O., Investigation of yarn dimensional behavior in weft knitted piqué structure and suitability to printing, In: Book of Proceedings 11th World Textile Conference Autex, 08.-10.06.2011 Mulhouse, France

[24] Duan J., Heimlich F., Heistermann T., Ehrmann A., Weber M.O., Trockenrelaxation von rundgestricken in abhängigkeit von den bindungselementen masche, henkel und flottung, In: Melliand Textilberichte, 94, 2013, pp. 162-163

\section{Authors:}

\section{ELEONORA GSELL \\ FRANK HEIMLICH \\ ANDREA EHRMANN \\ MARCUS O.WEBER}

Niederrhein University of Applied Sciences

Faculty of Textile and Clothing Technology

Webschulstr. 31, 41065 Mönchengladbach, Germany

Corresponding author:

ANDREA EHRMANN

andrea.ehrmann@fh-bielefeld.de

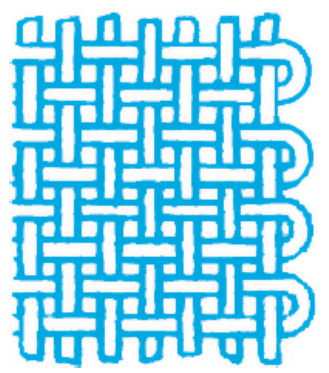




\title{
An investigation on the seam tensile properties of ultrasonically bonded nonwoven fabrics
}

\author{
ESRA ZEYNEP YILDIZ \\ OKTAY PAMUK
}

DOI: 10.35530/IT.068.02.1299

SERKAN BOZU

REZUMAT - ABSTRACT

\section{Studiu asupra proprietăților de rezistență la tracțiune a cusăturii articolelor neţesute consolidate cu ultrasunete}

În acest studiu, au fost investigate proprietățile de rezistență la tracțiune a cusăturii nețesutelor consolidate cu ultrasunete și s-au analizat efectele tipului de material, ale cilindrului și vitezei de coasere asupra proprietăților de rezistență la tracțiune a cusăturii mostrelor. S-a ajuns la concluzia că tipul de material, tipul cilindrului și viteza de coasere au un efect important din punct de vedere statistic asupra proprietăților de rezistență la tracțiune a cusăturii nețesutelor. Rezultatele experimentale indică faptul că, utilizând rola de gravare $4 \mathrm{~mm}$ lățime punct și o viteză de 25 dm/min, rezistența la tracțiune a cusăturilor realizate este cea mai mare, iar dacă se utilizează o rolă de gravare $9 \mathrm{~mm}$ lățime punct și $45 \mathrm{dm} / \mathrm{min}$, rezistența la tracțiune a cusăturilor este cea mai mică.

Cuvinte-cheie: nețesut, tipul cilindrului, rezistența cusăturii, viteza de coasere, coasere cu ultrasunete

\section{An investigation on the seam tensile properties of ultrasonically bonded nonwoven fabrics}

In this study, the seam tensile properties of the ultrasonically bonded nonwoven fabrics were investigated and the effects of the fabric type, roller type and sewing speed on the seam tensile properties of the samples were studied. It was deduced that fabric type, roller type and sewing speed have statistically significant effect on the seam tensile properties of the nonwoven fabrics. The experimental results indicate that, the tensile strength of the seams made with made with the engraving roller $4 \mathrm{~mm}$ wide point and $25 \mathrm{dm} / \mathrm{min}$ speed is the highest, and with the engraving roller $9 \mathrm{~mm}$ wide point and $45 \mathrm{dm} / \mathrm{min}$ is the lowest.

Keywords: nonwoven fabric, roller type, seam strength, sewing speed, ultrasonic sewing

\section{INTRODUCTION}

Sound can be defined as a longitudinal wave in a medium. The simplest sound waves are sinusoidal waves that have definite frequency, amplitude, and wave length. The term "ultrasonic" refers to acoustic frequencies above the range audible to the human ear [1]. The normal range of human hearing is between $16 \mathrm{~Hz}$ and $16 \mathrm{kHz}$, while ultrasonic frequencies are generally considered to lie between $20 \mathrm{kHz}$ and $500 \mathrm{MHz}$ [2]. In practice, three ranges of frequencies are reported for three distinct uses of ultrasound: low frequency or conventional power ultrasound (20-100 kHz), medium frequency ultrasound (300-1000 kHz) and diagnostic or high frequency ultrasound (2-10 MHz) [3].

Ultrasonic energy is mechanical vibratory energy, which operates at frequencies beyond audible sound [1]. Ultrasonic energy is conveyed by waves. These waves create compression and relaxation in molecular structures of the environment which they pass [2]. The field of ultrasonic is still making strides towards perfection, but many applications of ultrasonic waves have already been found in science and technology. Ultrasonic energy has been widely used in research for engineering (20-50 kHz) and medical science (1-10 MHz) for many years. The ultrasonic energy in these fields is used for; cleaning, sterilization, plastic welding, homogenization and filtration. Some examples of ultrasonic energy are military and non-military exploration of sea floor and sonar systems, nondestructive testing in material engineering, medical therapy and diagnosis. Ultrasonic energy is also widely used for cleaning and degreasing of parts and assemblies in automotive and other industries [2]. In textile process, ultrasound can offer potential benefits for shortening process time, reducing pollution load and achieving improvement in product quality. In 1941, the intensification effect of ultrasound on various textile processes was firstly reported by Sokolov and Tumansky [4]. It has been reported by several researchers that ultrasonic energy has been successfully applied to the textile processing steps such as desizing, dyeing, bleaching and washing [55-13]. Use of ultrasonic energy as sewing process in readymade garment production is also developing subject [2]. While ultrasonic seaming is not new, it could be a new technique for apparel manufacturers [14].

Sewing process can be defined as assembling of cut fabrics by using proper machines to obtain a cloth [2]. Sewing by needle and thread is the most common way of joining fabric together; however, current literature suggests there are alternative processes for creating fabric seams. These alternative methods include: thermal bonding, laser enhanced bonding, adhesive bonding, or ultrasonic sewing [14]. 
Ultrasonic sewing is an effective method to assemble the thermoplastic materials in industry. Ultrasonic assembly technology uses high frequency vibration to join two or more thermoplastic and thermoplastic blended materials [2]. This technique requires no needles, solvents, adhesives, mechanical fasteners, or other consumables, therefore reduces cost. Secondly, fiber degradation is minimized because heat energy is generated within the fibers using ultrasonic energy at the point of the joint site, unlike thermal bonding where heat energy is conducted through the fibers to melt them. This point bonding method, because of its nature, is clean, fast, non-contaminating, and efficient [1]. The use of foreign threads, yarns, and adhesives makes it harder or even impossible to recycle the product. This technique also eliminates impermeable seams, which make the use of such products safer [14].

Ultrasonic sewing provides smooth, durable, seamless appearance, enhanced wearer comfort, lighter weight products, waterproofness and clean edges with no discoloration of the fabric [15-16].

The ultrasonic joining machine consists of four main components: a generator, transducer, amplifier and rollers. Instead of a mechanism for making machine sewing stitches, there is an ultrasound transducer in the sewing machine head, which converts the alternating voltage of the ultrasound generator into mechanical oscillations. The oscillation amplitude is additionally enhanced in the amplifier, and the sonotrode guides it to the material to be joined. Mechanical oscillations of a relatively high frequency act on macromolecules, compelling them to movement as well as to the partial disruption and re-establishment of intermolecular bonds, which results in heat development. When the material heats up, a pressure of relatively low force is enough to join the materials permanently [17].

Ultrasonic sewing finds application in automotive industry, medical and hygienic products, sports, work and protective wears, covering and packaging, underwear, filter and technical textiles, shoe cover and curtains $[15,18]$.

Nonwoven fabrics are textile structures whose importance is increasing day by day. From the perspective of clothing, using nonwoven fabric for especially disposable clothing is of great importance especially in terms of cost. However, conventional stitch types create mechanical damage on nonwoven fabrics and hampers mobility. Therefore, the use of ultrasonic stitch is inevitable for sewing of nonwoven fabrics [18].

Although the use of ultrasound in textile process has led to an extensive interest, little document on the usage of ultrasonic energy in sewing process is published. In this article, the effects of fabric type, roller type and sewing speed on the seam tensile properties were examined.

\section{MATERIAL AND METHOD}

\section{Material}

Spunbond and meltblown webs are often combined at the production stage to achieve a variety of composite structures for protective applications particularly in the hygiene and medical sectors. In the SMS composite structure, the spunbond fabric provides the strength and the abrasion resistance and the meltblown component provides the liquid and particulates barrier. There are a variety of spunbond-meltblown structural combinations available, such as spunbond-meltblown-spunbond (SMS), spunbondmeltblown-meltblown-spunbond (SMMS), spunbondspunbond-meltblown-meltblown-spunbond (SSMMS) and others depending on the desirable final product properties [19].

In this study, 3 different $100 \%$ polypropylene nonwoven fabrics (SP, SMS and SMMS) with the same fabric area density were examined. In order to ignore the effects of fabric area density to the seam strength, it was kept constant. The properties of fabrics are given in table 1.

\begin{tabular}{|c|c|c|c|}
\hline No & Fabric type & Raw material & $\begin{array}{c}\text { Fabric area } \\
\text { density } \\
\left(\mathbf{g} / \mathbf{m}^{2}\right)\end{array}$ \\
\hline $\mathbf{1}$ & Spunbond & Polypropylene (PP) & 45 \\
\hline $\mathbf{2}$ & SMS & Polypropylene (PP) & 45 \\
\hline $\mathbf{3}$ & SMMS & Polypropylene (PP) & 45 \\
\hline
\end{tabular}

\section{Method}

\section{Ultrasonic sewing process}

Nonwoven fabrics were sewn by using Pfaff 8310 Seamsonic ultrasonic sewing machine (figure 1). The shape of the rollers affects the appearance and characteristics of the ultrasonic seam. Therefore, the ultrasonic sewing process was performed by using 2 different point engraving rollers with different widths (figure 2). Amplitude and the distance between horn and roller were kept constant. Samples were joined at different speeds as follows 25 and $45 \mathrm{dm} / \mathrm{min}$. The photos of sewn samples by using 2 different rollers are given in figure 3 .

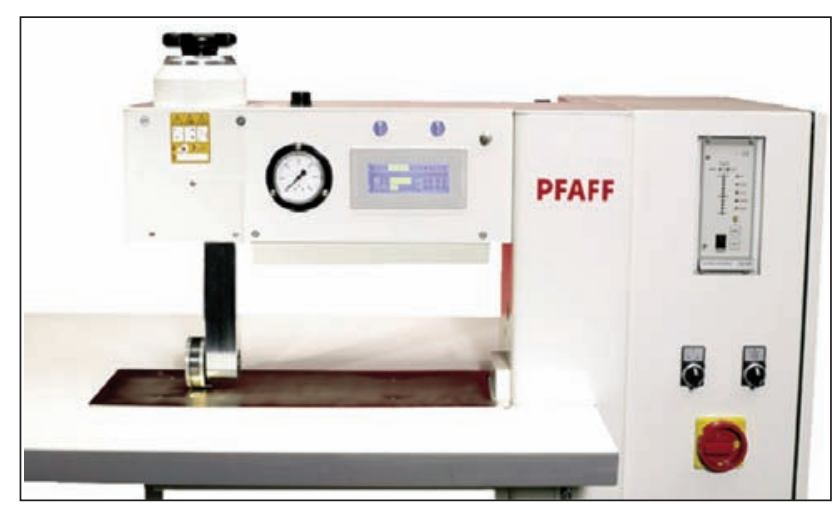

Fig. 1. Pfaff 8310 Seamsonic Ultrasonic Sewing Machine 


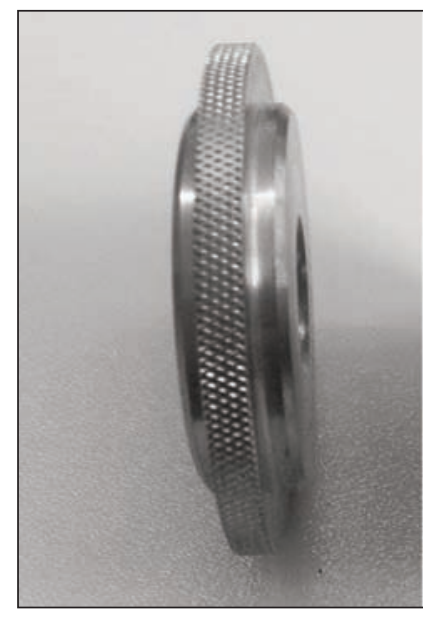

a

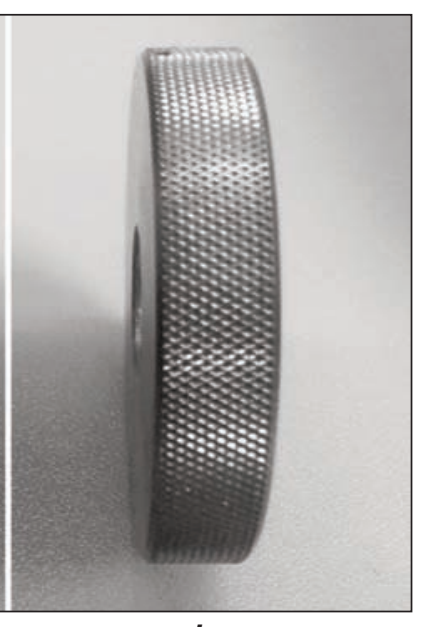

$\boldsymbol{b}$
Fig. 2. Point engraving rollers: $a-4 \mathrm{~mm}$ wide; $b-9 \mathrm{~mm}$ wide

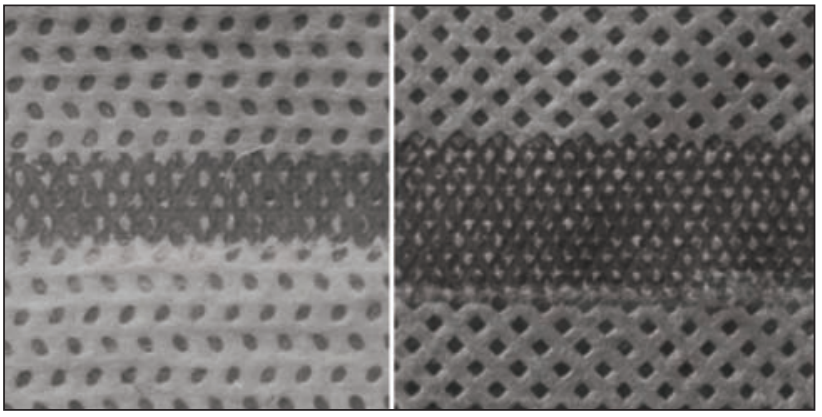

Fig. 3. Photos of the sewn samples by using 2 different rollers before seam strength test

\section{Seam strength test}

Seam strength tests were performed according to ISO 13935-2 standard "Textiles - Seam tensile properties of fabrics and made-up textile articles - Part 2: Determination of maximum force to seam rupture using the grab method" by using a Zwick Z010 testing instrument. Fabrics were cut to $350 \times 100 \mathrm{~mm}$, and then plied and ultrasonically bonded from $1 \mathrm{~cm}$ of the fabric edge. Speed of the instrument was set to $50 \mathrm{~mm} / \mathrm{min}$.

\section{Experimental design}

Statistical calculations were done using PASW 18 program. The effect of three variables (fabric type, roller type and sewing speed) on seam tensile properties was investigated according to full factorial experimental design with five replicates. Three levels were selected for fabric type, two levels were selected for roller type and sewing speed. Therefore, $3 \times 2 \times$ $\times 2=12$ different samples were produced in total. Factors and levels considered for the experiment are given in table 2 .

\begin{tabular}{|l|c|c|c|}
\hline \multicolumn{1}{|c|}{ Levels } & $\mathbf{1}$ & $\mathbf{2}$ & $\mathbf{3}$ \\
\hline Factors & SP & SMS & SMMS \\
\hline Fabric type & $\begin{array}{c}4 \mathrm{~mm} \text { wide } \\
\text { point } \\
\text { engraving }\end{array}$ & $\begin{array}{c}9 \mathrm{~mm} \text { wide } \\
\text { point } \\
\text { engraving }\end{array}$ & - \\
\hline Sewing speed & $25 \mathrm{dm} / \mathrm{min}$ & $45 \mathrm{dm} / \mathrm{min}$ & - \\
\hline
\end{tabular}

\section{RESULTS AND DISCUSSION}

The test results of studied fabrics are given in table 3 . In order to determine the statistical significance of the effects of roller type and sewing speed on seam tensile properties independent samples T-Tests were applied, whereas ANOVA tests were applied to investigate the effect of fabric type on the seam tensile properties. Tamhane's T2 post hoc test was conducted, according to the Levene Homogeneity test results. To deduce whether the parameters were significant or not, $p$ values were examined (table 4) according to $\alpha=0.05$ significance level.

According to the experimental results (figure 4) and statistical analysis (table 5), there is a significant effect of fabric type on seam strength. It can be observed that SMS and SMMS fabrics have higher seam tensile strength values (the differences between the rating values of these fabrics are not statistically significant). On the other hand, SP fabric has the lowest value.

Table 3

\begin{tabular}{|c|c|c|c|c|c|c|c|}
\hline Exp. no. & \multicolumn{3}{|c|}{ Levels } & Fabric type & Roller type & $\begin{array}{l}\text { Sewing speed } \\
(\mathrm{dm} / \mathrm{min})\end{array}$ & $\begin{array}{l}\text { Seam tensile } \\
\text { strength (N) }\end{array}$ \\
\hline 1 & 1 & 1 & 1 & SP & $4 \mathrm{~mm}$ wide & 25 & 65.186 \\
\hline 2 & 1 & 1 & 2 & SP & $4 \mathrm{~mm}$ wide & 45 & 65.512 \\
\hline 3 & 1 & 2 & 1 & SP & $9 \mathrm{~mm}$ wide & 25 & 67.374 \\
\hline 4 & 1 & 2 & 2 & SP & $9 \mathrm{~mm}$ wide & 45 & 61.122 \\
\hline 5 & 2 & 1 & 1 & SMS & $4 \mathrm{~mm}$ wide & 25 & 78.664 \\
\hline 6 & 2 & 1 & 2 & SMS & $4 \mathrm{~mm}$ wide & 45 & 71.756 \\
\hline 7 & 2 & 2 & 1 & SMS & $9 \mathrm{~mm}$ wide & 25 & 77.510 \\
\hline 8 & 2 & 2 & 2 & SMS & $9 \mathrm{~mm}$ wide & 45 & 63.506 \\
\hline 9 & 3 & 1 & 1 & SMMS & $4 \mathrm{~mm}$ wide & 25 & 89.514 \\
\hline 10 & 3 & 1 & 2 & SMMS & $4 \mathrm{~mm}$ wide & 45 & 71.368 \\
\hline 11 & 3 & 2 & 1 & SMMS & $9 \mathrm{~mm}$ wide & 25 & 78.888 \\
\hline 12 & 3 & 2 & 2 & SMMS & $9 \mathrm{~mm}$ wide & 45 & 58.286 \\
\hline
\end{tabular}




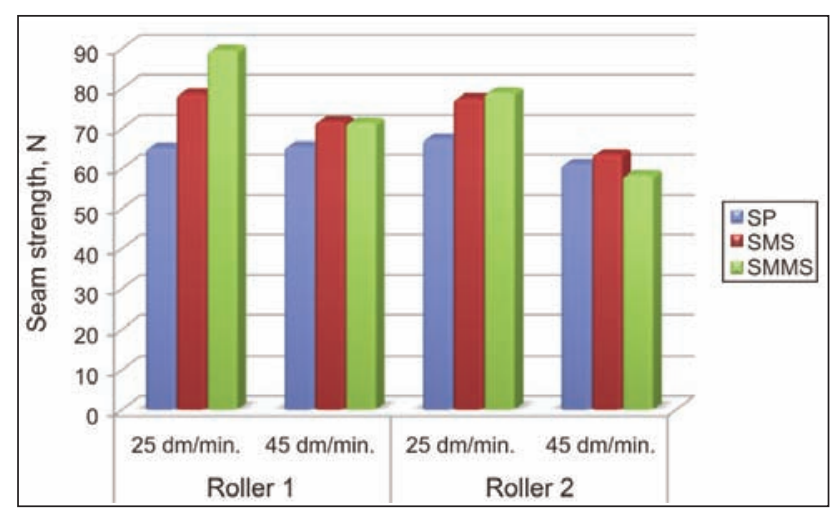

Fig. 4. Seam strength results of the samples according to fabric type

Table 4

\begin{tabular}{|c|c|c|}
\hline & Roller type & Sewing speed \\
\hline $\mathrm{p}$ value & $0,041^{*}$ & $0,000^{*}$ \\
\hline
\end{tabular}

*significant for $\alpha=0.05$

Table 5

\begin{tabular}{|c|c|c|c|}
\hline Fabric test & Group (I) & Group (J) & $p$ \\
\hline \multirow{6}{*}{ 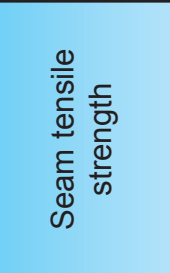 } & \multirow{2}{*}{ SP } & SMS & $0.032^{*}$ \\
\hline & & SMMS & $0.013^{*}$ \\
\hline & \multirow{2}{*}{ SMS } & SP & $0.032^{*}$ \\
\hline & & SMMS & 0.965 \\
\hline & \multirow{2}{*}{ SMMS } & SP & $0.013^{*}$ \\
\hline & & SMS & 0.965 \\
\hline
\end{tabular}

*significant for $\alpha=0.05$

SMS and SMMS nonwovens are formed of 3 or 4 layers of spunbond and meltblown plies. The result is considered to be caused by the increase in the layer number.

\section{Effect of roller type}

Seam strength values of the samples according to roller type are given in figure 5 . Tensile strength of the ultrasonic seams obtained with the $4 \mathrm{~mm}$ wide point engraving roller ranges from $65.186 \mathrm{~N}$ to $89.514 \mathrm{~N}$, whereas tensile strength of the ultrasonic seams obtained with the $9 \mathrm{~mm}$ wide point engraving roller ranges from $58.286 \mathrm{~N}$ to $78.888 \mathrm{~N}$. According to the experimental results (figure 5 ) and statistical analysis (table 4), there is a significant effect of roller type on seam strength.

When tensile strength of the samples sewn by different rollers is compared, it can be seen that as the width of the roller increases, the strength of ultrasonic sewing reduces.

Due to the high number of connection points per unit length, the seam strength increases in seams obtained by the use of discontinuous pattern rollers. However, there is no specific relation between the surface area and strength in continuous pattern rollers like point engraving rollers. Also, in continuous pattern rollers, the thermoplastic materials molten between the rollers can spewed out (blow).

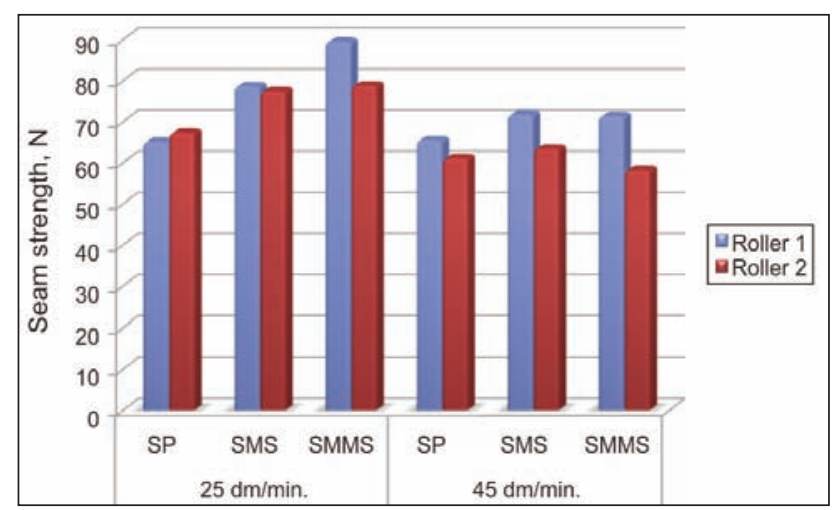

Fig. 5. Seam strength results of the samples according to roller type

Therefore, as the width of the roller increases, there can be a decline in the strength.

\section{Effect of sewing speed}

Seam strength results of the samples according to sewing speed are given in figure 6 . The tensile strength of the ultrasonic seams obtained with 25 $\mathrm{dm} / \mathrm{min}$ speed ranges from $65.186 \mathrm{~N}$ to $89.514 \mathrm{~N}$, whereas seams obtained with $45 \mathrm{dm} / \mathrm{min}$ speed ranges from $58.286 \mathrm{~N}$ to $71.756 \mathrm{~N}$. According to the experimental results (figure 6 ) and statistical analysis (table 4), there is a significant effect of sewing speed on seam strength.

With reference to experimental results, it can be stated that seam strength is less for samples sewn with $45 \mathrm{dm} / \mathrm{min}$. As sewing speed increases, the application time of ultrasound to the fabric is reduced. For this reason, the fabric is subjected to less vibration and melts less. Thus the connection points become weaker.

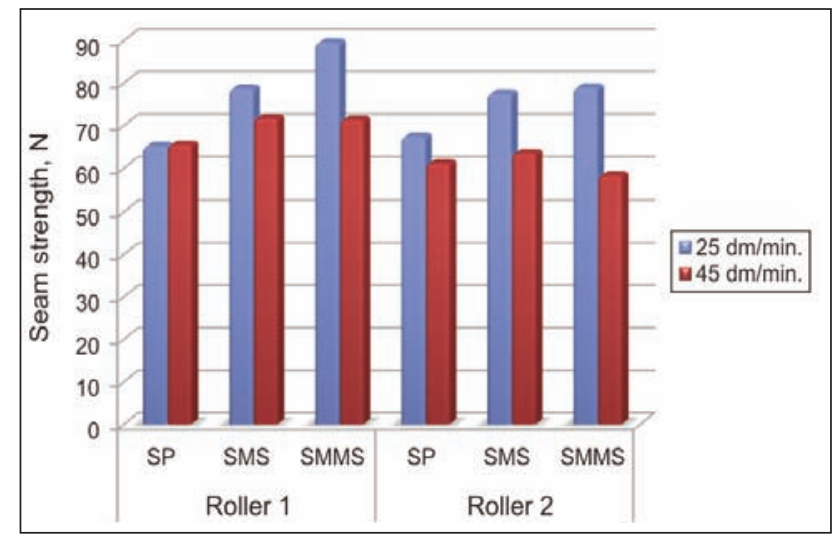

Fig. 6. Seam strength results of the samples according to sewing speed

\section{CONCLUSIONS}

In this study, it is aimed to investigate the seam tensile properties of the ultrasonically bonded nonwoven fabrics and to analyze the effects of the fabric type, roller type and sewing speed on the seam tensile properties of the samples. For this purpose, 3 different PP nonwoven fabrics with the same fabric area densities were used. Then fabrics were bonded to 
each other by using ultrasonic sewing machine with different speeds (25 dm/min and $45 \mathrm{dm} / \mathrm{min}$ ). Ultrasonic sewing process was performed by using point engraving rollers with different widths $(4 \mathrm{~mm}$ and $9 \mathrm{~mm}$ ).

The results obtained can be summarized as follows:

- According to the experimental results and statistical analysis, strength of ultrasonically bonded seams is significantly influenced by fabric type, roller type and sewing speed.

- Due to seam strength results; SMMS fabric has the highest values, whereas SP fabric has the lowest values.
- The sewing speed has a negative effect on the seam strength results. As the speed increases, the seam strength values decrease.

- There is no specific relation between the surface area and seam strength in continuous pattern rollers like point engraving rollers. Therefore, contrary to expectations it is found that the seam strength decreases significantly when the width of the roller increases.

- When strength values of the samples are evaluated, the maximum value is obtained with the $4 \mathrm{~mm}$ wide point engraving roller and $25 \mathrm{dm} / \mathrm{min}$ speed, while $9 \mathrm{~mm}$ wide point engraving roller and 45 $\mathrm{dm} / \mathrm{min}$ has the minimum value.

\section{BIBLIOGRAPHY}

[1] Reddy R.K. Ultrasonic Seaming of PET, PET/Cotton Blend, and Spectra Fabrics, Master of Science thesis, Eastern Michigan University, 2007.

[2] Kayar, M., Mıstık, S.I.., Effect of fiber type and polyethylene film on mechanical properties of ultrasonically bonded multi layer nonwoven fabrics. In: Tekstil ve Konfeksiyon, 2014, vol. 24, issue 1, pp. 30-36.

[3] Vajnhandl, S., Majcen Le Marechal, A., Ultrasound in textile dyeing and the decolouration/mineralization of textile dyes, In: Dyes and Pigments, 2005, vol. 65, issue 2, pp. 89-101.

[4] Sun, D., Guo, Q., Liu, X., Investigation into dyeing acceleration efficiency of ultrasound energy, In: Ultrasonics, 2010, vol. 50, issue 4-5, pp. 441-446.

[5] Wang, W., Yu, B., Zhong, C., Use of ultrasonic energy in the enzymatic desizing of cotton fabric, In: Journal of Cleaner Production, 2012, vol. 33, pp. 179-182.

[6] Li, X. and Qui, Y., The application of $\mathrm{He} / \mathrm{O}_{2}$ atmospheric pressure plasma jet and ultrasound in desizing of blended size on cotton fabrics, In: Applied Surface Science, 2012, vol. 258, issue 19, pp. 7787-7793.

[7] Khatri, Z., Memon, M.H., Khatri, A., Tanwari, A., Cold pad-batch dyeing method for cotton fabric dyeing with reactive dyes using ultrasonic energy, In: Ultrasonic Sonochemistry, 2011, vol. 18, issue 6, pp. 1301-1307.

[8] Sivakumar, V., Rao, P.G. ,Studies on the use of power ultrasound in leather dyeing, In: Ultrasonics Sonochemistry, 2003, vol. 10, issue 2, pp. 85-94.

[9] Kamel, M.M., El-Shishtawey, R.M., Hanna, H.L., Ahmed, N.S.E., Ultrasonic-assisted dyeing: 1. Nylon dyeability with reactive dyes, In: Polymer International, 2003, vol. 52, issue 3, pp. 373-380.

[10] Mıstık, S.I.., Yükseloğlu, S.M., Hydrogen peroxide bleaching of cotton in ultrasonic energy, In: Ultrasonics, 2005, vol. 43, issue 10, pp. 811-814.

[11] Basto, C., Tzanov, T., Cavaco-Paulo, A., Combined ultrasound-laccase assisted bleaching of cotton, In: Ultrasonics Sonochemistry, 2007, vol. 14, issue 3, pp. 350-354.

[12] Canoğlu, S., Gültekin, B.C., Yükseloğlu, S.M., Effect of ultrasonic energy in washing of medical surgery gowns, In: Ultrasonics, 2004, vol. 42, issue 1-9, pp. 113-119.

[13] Akalın, M., Merdan, N., Koçak, D., Usta, I. , Effects of ultrasonic energy on the wash fastness of reactive dyes, In: Ultrasonics, 2004, vol. 42, issue 1-9, pp. 161-164.

[14] Boles, K., Examination of alternative fabric joining techniques compared to traditional sewing, In: McNair Scholars Research Journal, 2012, vol. 5, issue 1, pp. 1-17.

[15] Jana, P., Assembling technologies for functional garments - An overview, In: Indian Journal of Fibre \& Textile Research, 2011, vol. 36, pp. 380-387.

[16] Busiliene, G., Strazdiene, E., Urbelis, V., Krauledas, S., The effect of bonded seams upon spatial behaviour of knitted materials systems, In: Materials Science (MEDZIAGOTYRA), 2015, vol. 21, issue 2, pp. 271-275.

[17] Ujević D., Kovačević S., Horvat-Varga S., Analysis of high-frequency artificial leather welding as a function of seam quality, In: Fibres \& Textiles in Eastern Europe, 2011, vol. 19, issue 4 (87), pp. 94-100.

[18] Kayar, M., Analysis of ultrasonic seam tensile properties of thermal bonded nonwoven fabrics, In: Journal of Engineered Fibers and Fabrics, 2014, vol. 9, issue 3, pp. 8-18.

[19] Russell, S. Handbook of Nonwovens, Woodhead Publishing in Textiles, England, 2006.

$\begin{array}{cc}\text { ESRA ZEYNEP YILDIZ1 } & \text { Authors: } \\ \text { OKTAY PAMUK } & \\ \text { SERKAN BOZ1 } & \begin{array}{c}\text { Textile Engineering Department, Ege University, } \\ \text { Izmir, Turkey }\end{array} \\ \text { 1 Emel Akin Vocational Training School, } & \text { Corresponding author: } \\ \text { Ege University, Izmir, Turkey } & \text { ESRA ZEYNEP YILDIZ } \\ \text { esra.zeynep.yildiz@ege.edu.tr }\end{array}$




\section{Correlation study of multifunctional knitted textile structures characteristics}

EFTALEA CĂRPUS

DOI: $10.35530 / \mathrm{IT} .068 .02 .1271$

CARMEN MIHAI

Studiul corelaţiei caracteristicilor structurilor textile tricotate multifuncţionale

Sistemele textile utilizate pentru îmbunătățirea abilităților de monitorizare a sănătății oamenilor sunt rezultatul activității de cercetare şi inovare a colectivelor multidisciplinare. În acest caz, natura proiectării poate implica: o rezolvare de problemă practică; execuția unei decizii; o aplicare a ştiinței; o căutare euristică; creativitate şi imaginație; transfer şi transformare de cunoştințe; o colecatre şi procesare de date; desen şi calcul.

Un factor important în luarea deciziei de proiectare-realizare a structurilor textile flexibile-interactive ce se pot folosi ca element de ataşare a unor dispozitive de monitorizare este cunoaşterea potențialelor interdependențe dintre caracteristicile produsului. Utilizând Programul SPSS (Statistical Package for the Social Sciences), lucrarea prezintă corelațiile ce se pot lua în considerație în definirea structurii şi formei anatomice a structurii tricotate pe sistem de tricotare tip seamless.

Cuvinte-cheie: corelare caracteristici, structuri textile interactive

\section{Correlation study of multifunctional knitted textile structures characteristics}

Textile systems used to improve people's health monitoring abilities are the result of research and innovation of multidisciplinary teams. In this case, the nature of design may involve: solving of the practical problems, execution of decisions; application of science, heuristic search; creativity and imagination, knowledge transfer and transformation; data collection and processing; drawing and calculation.

An important/key factor about making of the design decision - providing flexible, interactive textile structures that can be used as attachment element of monitoring devices in known for the linkages potential between product characteristics. Using SPSS (Statistical Package for the Social Sciences), the paper shows the correlations that can be taken into account in determining the structure and shape of anatomical knitted structure processed on seamless type knitting system.

Key-words: characteristics correlation, interactive textile structures

\section{INTRODUCTION}

As a response of the European changes, in the framework of Horizon 2020 program the research and innovation have as priority direction the development of a sustainable health system with help of the various tools that provide both customization and implementation of medical prevention activities.

In this case, research and innovation activities must ensure:

- improving capacity to understand the causes and mechanisms underlying health maintenance;

- improving health monitoring skills;

- support to older people in order to be active and healthy;

- new models and care tools.

In this context, the textile systems are characterized by innovation, depending on patient satisfaction and product quality, considering threshold performance and excellence characteristics [1-2]. For these products, the design activity represents a multidisciplinary and creative activity, whose aim is to satisfy known functional specifications: restrictions imposed by environmental, performance requirements (time, space, power, cost, etc.) structure (style, clarity, etc.), and restrictions of the self-design process. When design problems are well structured, the algorithm is constructed in a manner to meet all system requirements, taking as a starting point the performance of each element of the whole structure and knowledge of the responses "shape" [3-4].

The use of intelligent textiles as wearable devices (sensors or actuators) or flexible support for attaching these devices must satisfy a number of requirements to ensure a number of requirements in order to guarantee results and appropriate response to user.

Work in recent developments in flexible wearable electronics for monitoring applications is still needed in order to resolve all the technicalities, particularly with regards to the following: accuracy and reliability of data measurement (noise reduction); reliability, safety and security of data transfer; simplification of the systems by multi-functional textiles; efficiency of power management, including power generation; durability of the systems, including wash-ability and longterm accuracy in performance; user-friendliness, including the ability to use/wear the garments without the essential need for assistance; mobility, including weight reduction; cost versus product lifespan or 
durability; comfort and physical aesthetics, including breathability, absorbency, drape, handle, etc. [5]. In terms of classification criteria, implemented by scientific literature, intelligent textiles range applications used for performance improvement of treatment and, consequently, increasing the quality of life of patients refer to:

- disease management or remote monitoring (involving interactions with the patient's participation in functional elements embedded in textiles);

- textile systems role in each clinical stage:

- Diagnostic/complementary exploration/monitoring and recording signals (ie, Holter monitoring body temperature, sweating, etc.);

- Secondary prevention: detecting of associated risks and communicating od physical changes (biofeedback) to prevent health problems;

- Medical treatment, which act on existing problems, modulating the response.

Literature [6-10] proposes to monitor a number of physiological and biomechanical parameters, including: heart rate (pulse), respiratory, sleep apnea, hyperventilation syndrome, blood pressure, body temperature, blood oxygen saturation, $\mathrm{pH}$, movement models, sudden infant death syndrome, agitation state, muscle tonus.

\section{EXPERIMENTAL PART}

To achieve textile structures with multifunctional properties, in order to determine dependencies, experimentation matrix has considered capitalization of the:

- textile fibers properties in the context of ensuring psycho-sensorial comfort;

- physical-mechanical potential of the knitted structures made on knitting machines with "anatomical cuts" structure design system, and comfort in motion;

- seamless knitting system advantages.
The experimentation plan contains 15 different knitted samples, depending on type of yarn used and knitted structure, shown in table 1.

In order to characterize test variants, in accordance to reference documents and specific procedures, the parameters that characterize dimensional structure and comfort were determined, as the following: mass/unit area $\left[\mathrm{g} / \mathrm{m}^{2}\right.$ ], knitted fabric density [rows and/or wales $/ 10 \mathrm{~cm}]$, thickness [mm], water vapor permeability [\%], and air permeability $\left[1 / \mathrm{m}^{2} / \mathrm{sec}\right]$

For establishing potential correlations, SPSS software (Statistical Package for the Social Sciences), one of the most used in statistical analysis was used. SPSS operation include: interface, data management, statistical analysis. SPSS uses data organized in rows and columns, in which the lines represent cases (observations), and columns represent research variables. The Initializing (figure 1) and controls visualization for cases summarizing (figure 2 , table 2,3 ) of the database define group of analyzed characteristics (table 4).

Correlation analysis, performed with the purpose of calculating the correlation between the variables studied (bivariate because they considered it necessary to calculate the correlation between all variables, taken two by two). For variables entered in the database was used Pearson correlation and bidirectional threshold. The data obtained are shown in table 5 . In case of positive sign of correlation shows that relationship between variables is proportional, and in case of negative one, the relationship between variables is inversely proportional. Absolute size of coefficient (which describes the strength of the link between variables) shows that between all variables which are analyzed there is a strong correlation $(r>0.50)$.

\begin{tabular}{|c|c|c|c|c|c|c|}
\hline \multicolumn{7}{|c|}{ CODED VARIANTS, DEPENDING ON STRUCTURE USED AND YARN TYPE } \\
\hline \multirow{2}{*}{ Yarn code } & \multicolumn{7}{c|}{ Structure code } \\
\cline { 2 - 7 } & $\mathrm{S}_{1}$ & $\mathrm{~S}_{2}$ & $\mathrm{~S}_{3}$ & $\mathrm{~S}_{4}$ & $\mathrm{~S}_{5}$ & $\mathrm{~S}_{6}$ \\
\hline A+D & - & $\mathrm{V}_{1}$ & $\mathrm{~V}_{2}$ & $\mathrm{~V}_{3}$ & $\mathrm{~V}_{4}$ & $\mathrm{~V}_{5}$ \\
\hline B+C & - & $\mathrm{V}_{6}$ & $\mathrm{~V}_{7}$ & $\mathrm{~V}_{8}$ & $\mathrm{~V}_{9}$ & $\mathrm{~V}_{10}$ \\
\hline A & $\mathrm{V}_{11}$ & - & $\mathrm{V}_{12}$ & $\mathrm{~V}_{13}$ & $\mathrm{~V}_{14}$ & $\mathrm{~V}_{15}$ \\
\hline
\end{tabular}

Legend:

$A+D$ Base yarn: $N m$ 70, elastomer mono-filamentary yarn, wound with an yarn made of PA and cotton fibers; Supplementary yarn: Nm 20, 100\% COOLMAX PES yarn:

$B+C \quad$ Base yarn, Nm 180, elastomer mono-filamentary, textured yarn wound with PA microfilaments;

Supplementary yarn: Nm 100, 100\% PES, multi-filamentary yarn (micro filaments);

A $\quad \mathrm{Nm} 70$, elastomer mono-filamentary yarn wound with a yarn made of PA and cotton fibers;
Single Jersey;

Plated Jersey;

Single Jersey with miss inlay stitches;

Single Jersey with miss stitches $-1 \times 1$;

Single Jersey with miss stitches $-1 \times 2$;

$S_{6} \quad$ Single Jersey with miss stitches $-2 \times 2$;

$V_{1}-V_{15}$ Knitted fabric sample code. 


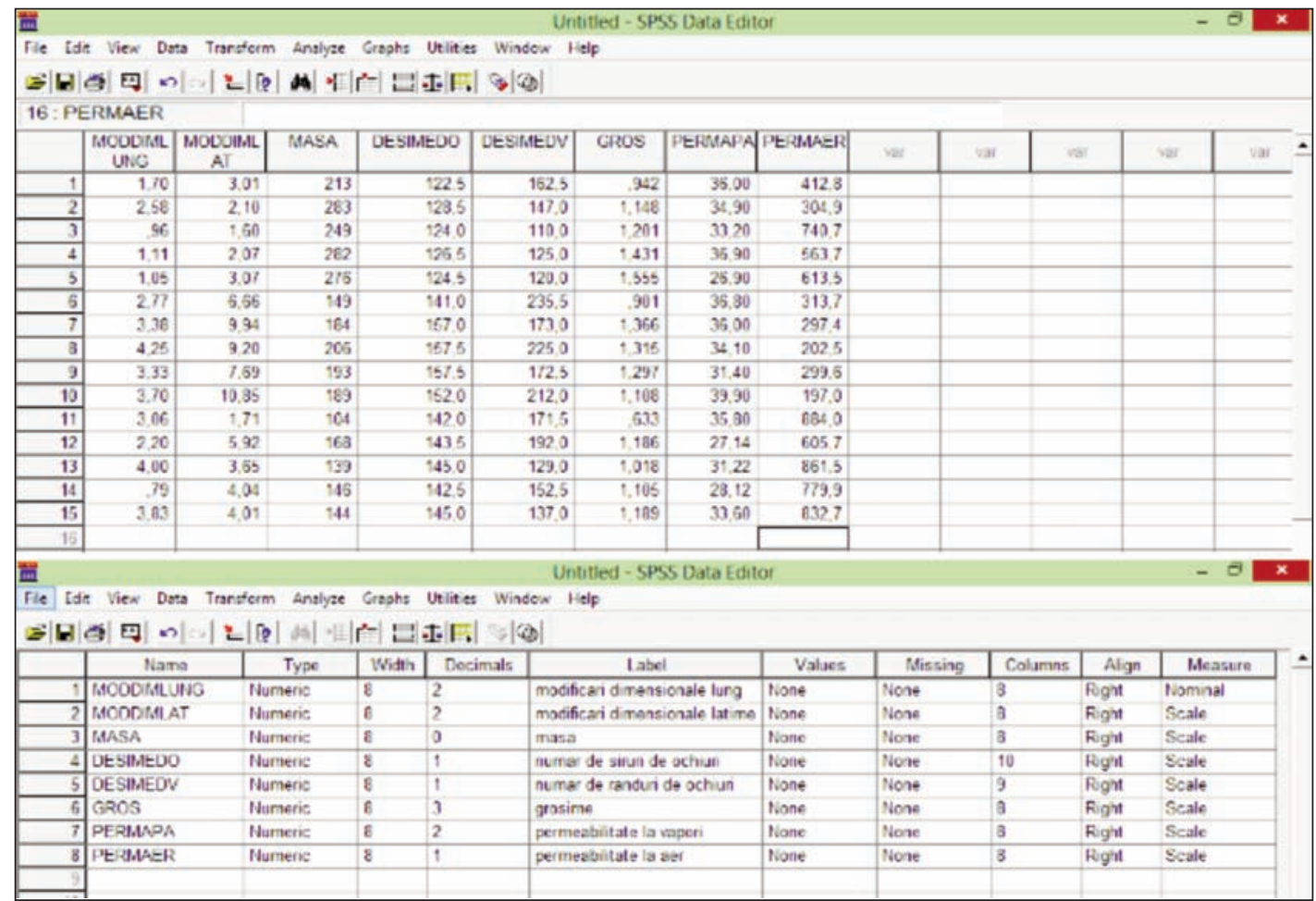

Fig. 1. Data base initialization

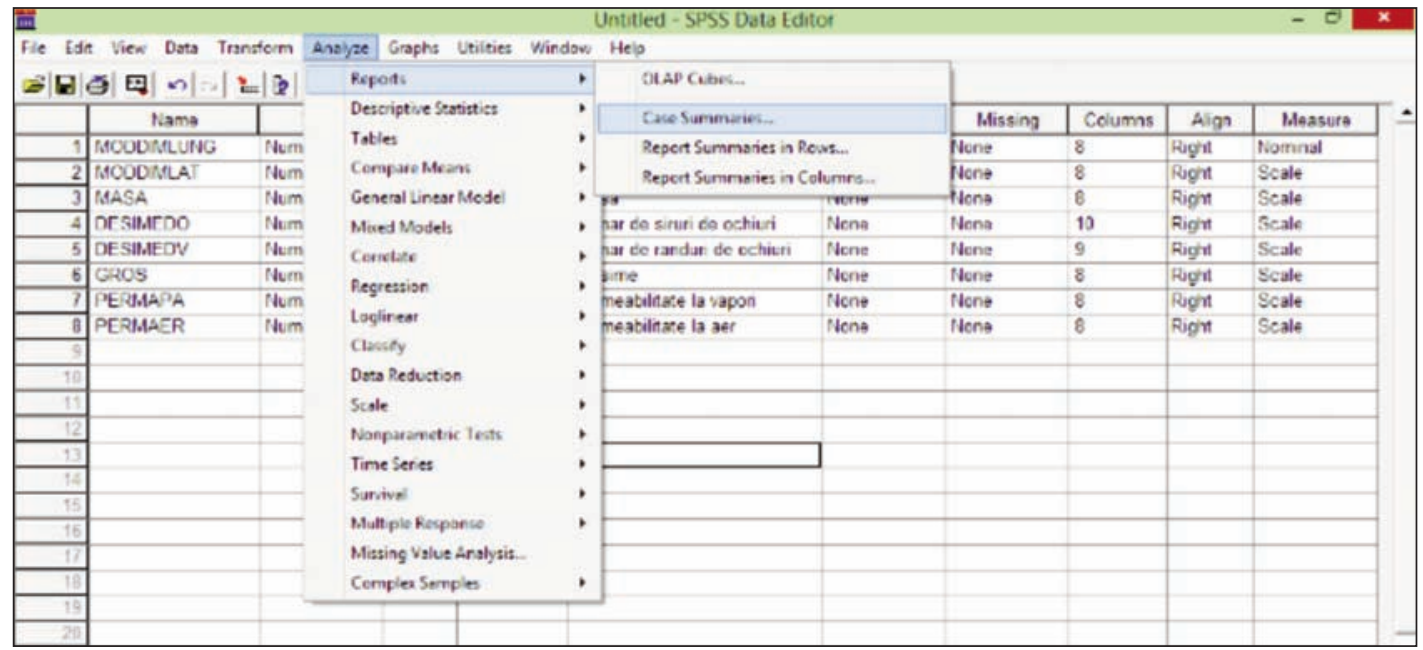

Fig. 2. Controls visualization for cases summarizations

CASE PROCESSING SUMMARY (A)

\begin{tabular}{|c|c|c|c|c|c|c|}
\hline & & - & & & & \\
\hline \multirow{3}{*}{ Characteristics } & \multicolumn{6}{|c|}{ Cases } \\
\hline & \multicolumn{2}{|c|}{ Included } & \multicolumn{2}{|c|}{ Excluded } & \multicolumn{2}{|c|}{ Total } \\
\hline & $\mathbf{N}$ & Percent & $\mathbf{N}$ & Percent & $\mathbf{N}$ & Percent \\
\hline Dimensional changes (length) & 15 & $100.0 \%$ & 0 & $0.0 \%$ & 15 & $100.0 \%$ \\
\hline Dimensional changes (width) & 15 & $100.0 \%$ & 0 & $0.0 \%$ & 15 & $100.0 \%$ \\
\hline Mass & 15 & $100.0 \%$ & 0 & $0.0 \%$ & 15 & $100.0 \%$ \\
\hline No. of wales & 15 & $100.0 \%$ & 0 & $0.0 \%$ & 15 & $100.0 \%$ \\
\hline No. of rows & 15 & $100.0 \%$ & 0 & $0.0 \%$ & 15 & $100.0 \%$ \\
\hline Thickness & 15 & $100.0 \%$ & 0 & $0.0 \%$ & 15 & $100.0 \%$ \\
\hline Water vapor permeability & 15 & $100.0 \%$ & 0 & $0.0 \%$ & 15 & $100.0 \%$ \\
\hline Air permeability & 15 & $100.0 \%$ & 0 & $0.0 \%$ & 15 & $100.0 \%$ \\
\hline
\end{tabular}

a - limited to first 100 cases 


\begin{tabular}{|c|c|c|c|c|c|c|c|c|c|}
\hline \multicolumn{10}{|c|}{ CASE SUMMARIES (A) } \\
\hline & & $\begin{array}{c}\text { Dimensional } \\
\text { changes } \\
\text { (length) }\end{array}$ & $\begin{array}{l}\text { Dimensional } \\
\text { changes } \\
\text { (width) }\end{array}$ & Mass & $\begin{array}{l}\text { No. of } \\
\text { wales }\end{array}$ & $\begin{array}{l}\text { No. of } \\
\text { rows }\end{array}$ & Thickness & $\begin{array}{l}\text { Water vapour } \\
\text { permeability }\end{array}$ & $\begin{array}{c}\text { Air } \\
\text { permeability }\end{array}$ \\
\hline \multicolumn{2}{|l|}{1} & 1.70 & 3.01 & 213 & 122.5 & 162.5 & 0.942 & 36.00 & 412.8 \\
\hline \multicolumn{2}{|l|}{2} & 2.58 & 2.10 & 283 & 128.5 & 147.0 & 1.148 & 34.90 & 304.9 \\
\hline \multicolumn{2}{|l|}{3} & 0.96 & 1.60 & 249 & 124.0 & 110.0 & 1.201 & 33.20 & 740.7 \\
\hline \multicolumn{2}{|l|}{4} & 1.11 & 2.07 & 282 & 126.5 & 125.0 & 1.431 & 36.90 & 563.7 \\
\hline \multicolumn{2}{|l|}{5} & 1.05 & 3.07 & 276 & 124.5 & 120.0 & 1.555 & 26.90 & 613.5 \\
\hline \multicolumn{2}{|l|}{6} & 2.77 & 6.66 & 149 & 141.0 & 235.5 & 0.901 & 36.80 & 313.7 \\
\hline \multicolumn{2}{|l|}{7} & 3.38 & 9.94 & 184 & 157.0 & 173.0 & 1.366 & 36.00 & 297.4 \\
\hline \multicolumn{2}{|l|}{8} & 4.25 & 9.20 & 206 & 157.5 & 225.0 & 1.315 & 34.10 & 202.5 \\
\hline \multicolumn{2}{|l|}{9} & 3.33 & 7.69 & 193 & 157.5 & 172.5 & 1.297 & 31.40 & 299.6 \\
\hline \multicolumn{2}{|c|}{10} & 3.70 & 10.85 & 189 & 152.0 & 212.0 & 1.108 & 39.90 & 197.0 \\
\hline \multicolumn{2}{|c|}{11} & 3.06 & 1.71 & 104 & 142.0 & 171.5 & 0.633 & 35.80 & 884.0 \\
\hline \multicolumn{2}{|c|}{12} & 2.20 & 5.92 & 168 & 143.5 & 192.0 & 1.186 & 27.14 & 605.7 \\
\hline \multicolumn{2}{|c|}{13} & 4.00 & 3.65 & 139 & 145.0 & 129.0 & 1.018 & 31.22 & 861.5 \\
\hline \multicolumn{2}{|c|}{14} & 0.79 & 4.04 & 146 & 142.5 & 152.5 & 1.105 & 28.12 & 779.9 \\
\hline \multicolumn{2}{|c|}{15} & 3.83 & 4.01 & 144 & 145.0 & 137.0 & 1.189 & 33.60 & 832.7 \\
\hline Total & $\mathrm{N}$ & 15 & 15 & 15 & 15 & 15 & 15 & 15 & 15 \\
\hline
\end{tabular}

a - limited to first 100 cases

Table 4

\begin{tabular}{|l|c|c|c|c|c|}
\hline \multicolumn{7}{|l|}{ DESCRIPTIVE STATISTICS } \\
\hline & $\mathbf{N}$ & Minimum & Maximum & Mean & Std. Deviation \\
\hline Dimensional changes (length) & 15 & 0.79 & 4.25 & 2.581 & 1.2053 \\
\hline Dimensional changes (width) & 15 & 1.60 & 10.85 & 5.035 & 3.1382 \\
\hline Mass & 15 & 104 & 283 & 195.000 & 56.4800 \\
\hline No. of wales & 15 & 122.5 & 157.5 & 140.600 & 12.6225 \\
\hline No. of rows & 15 & 110.0 & 235.5 & 164.300 & 38.6189 \\
\hline Thickness & 15 & 0.633 & 1.555 & 1.1597 & 0.229326 \\
\hline Water vapor permeability & 15 & 26.90 & 39.90 & 33.4653 & 3.83745 \\
\hline Air permeability & 15 & 197.0 & 884.0 & 527.3070 & 251.2730 \\
\hline Valid N (listwise) & 15 & & & & \\
\hline
\end{tabular}

\section{RESULTS AND DISCUSSIONS}

\section{Verification of distribution form}

The form data distribution was verified with Kolmogorov-Smirnov non-parametric test, through menu: ANALYZE - non parametric SAMPLE TESTS K-S (table 6).

Analyzing the Kolmogorov-Smirnov test (table 6), we find that the 8 Kolmogorov-Smirnov calculated levels correspond to the thresholds of significance between 0.869 and 0.487 , so are greater than the critical threshold of 0.05 , which allows us to affirm that normality assumption is fulfilled.

\section{Regression equations}

Considering that the knitted structures are designed to develop textile systems for monitoring of biome- chanical/biological parameters, the design algorithm take into account the fact that the requirements for use will induce/define the characteristics of the structure, which in the context of the project are: specific mass, thickness.

In order to obtain a good prediction of the dependence between some physical-mechanical and engineered characteristics, a multiple linear regression analyze has been used. The following mathematical models were considered:

$$
Y=a+b \times x_{1}+c \times x_{2}
$$

Mass $=f$ (air permeability, water vapor permeability)

$$
\begin{aligned}
\text { Mass } & =330.4-2.5 \times \text { air_permeab - } \\
& -0.09 \times \text { water_vap_permeab }
\end{aligned}
$$

Thickness $=f($ air permeability, water vapor permeability) 


\begin{tabular}{|c|c|c|c|c|c|c|c|c|c|}
\hline \multicolumn{10}{|c|}{ CORRELATION } \\
\hline & & Mass & $\begin{array}{c}\text { Dimensional } \\
\text { changes } \\
\text { (length) }\end{array}$ & $\begin{array}{l}\text { Dimensional } \\
\text { changes } \\
\text { (width) }\end{array}$ & $\begin{array}{l}\text { No. of } \\
\text { wales }\end{array}$ & $\begin{array}{l}\text { No. of } \\
\text { rows }\end{array}$ & Thickness & $\begin{array}{c}\text { Water } \\
\text { vapor per- } \\
\text { meability }\end{array}$ & $\begin{array}{c}\text { Air per- } \\
\text { meability }\end{array}$ \\
\hline \multirow{3}{*}{ Mass } & Pearson Correlation & 1.000 & -0.474 & -0.227 & $-0.571\left(^{*}\right)$ & -0.392 & $0.665\left(^{* *}\right)$ & 0.018 & -0.352 \\
\hline & Sig. (2-tailed) & & 0.074 & 0.416 & 0.026 & 0.149 & 0.007 & 0.949 & 0.198 \\
\hline & $N$ & 15 & 15 & 15 & 15 & 15 & 15 & 15 & 15 \\
\hline \multirow{3}{*}{$\begin{array}{l}\text { Dimension } \\
\text { al changes } \\
\text { (length) }\end{array}$} & Pearson Correlation & -0.474 & 1.000 & $0.585\left(^{*}\right)$ & $0.765\left(^{* *}\right)$ & 0.501 & -0.204 & 0.350 & -0.281 \\
\hline & Sig. (2-tailed) & 0.074 & & 0.022 & 0.001 & 0.057 & 0.467 & 0.201 & 0.310 \\
\hline & $N$ & 15 & 15 & 15 & 15 & 15 & 15 & 15 & 15 \\
\hline \multirow{3}{*}{$\begin{array}{l}\text { Dimension } \\
\text { al changes } \\
\text { (width) }\end{array}$} & Pearson Correlation & -0.227 & $0.585\left(^{*}\right)$ & 1. 000 & $\left.0.813^{(* *}\right)$ & $0.733\left(^{* *}\right)$ & 0.203 & 0.247 & $\left.-0.690{ }^{(* *}\right)$ \\
\hline & Sig. (2-tailed) & 0.416 & 0.022 & & 0.000 & 0.002 & 0.467 & 0.375 & 0.004 \\
\hline & $N$ & 15 & 15 & 15 & 15 & 15 & 15 & 15 & 15 \\
\hline \multirow{3}{*}{$\begin{array}{l}\text { No. of } \\
\text { wales }\end{array}$} & Pearson Correlation & $-0.571\left(^{*}\right)$ & $0.765\left({ }^{* *}\right)$ & $0.813\left({ }^{* *}\right)$ & 1. 000 & $0.598\left(^{*}\right)$ & -0.010 & 0.083 & -0.307 \\
\hline & Sig. (2-tailed) & 0.026 & 0.001 & 0.000 & & 0.018 & 0.971 & 0.770 & 0.266 \\
\hline & $N$ & 15 & 15 & 15 & 15 & 15 & 15 & 15 & 15 \\
\hline \multirow{3}{*}{$\begin{array}{l}\text { No. of } \\
\text { rows }\end{array}$} & Pearson Correlation & -0.392 & 0.501 & $0.733\left({ }^{* *}\right)$ & $0.598\left(^{*}\right)$ & 1. 000 & -0.295 & 0.342 & $-0.631\left(^{*}\right)$ \\
\hline & \begin{tabular}{|l|} 
Sig. (2-tailed) \\
\end{tabular} & 0.149 & 0.057 & 0.002 & 0.018 & & 0.286 & 0.212 & 0.012 \\
\hline & $N$ & 15 & 15 & 15 & 15 & 15 & 15 & 15 & 15 \\
\hline \multirow{3}{*}{ Thickness } & Pearson Correlation & $\left.0.665^{(* *}\right)$ & -0.204 & 0.203 & -0.010 & -0.295 & 1. 000 & -0.315 & -0.266 \\
\hline & Sig. (2-tailed) & 0.007 & 0.467 & 0.467 & 0.971 & 0.286 & & 0.253 & 0.338 \\
\hline & $N$ & 15 & 15 & 15 & 15 & 15 & 15 & 15 & 15 \\
\hline \multirow{3}{*}{$\begin{array}{l}\text { Water } \\
\text { vapor per- } \\
\text { meability }\end{array}$} & Pearson Correlation & 0.018 & 0.350 & 0.247 & 0.083 & 0.342 & -0.315 & 1. 000 & -0.443 \\
\hline & Sig. (2-tailed) & 0.949 & 0.201 & 0.375 & 0.770 & 0.212 & 0.253 & & 0.098 \\
\hline & $N$ & 15 & 15 & 15 & 15 & 15 & 15 & 15 & 15 \\
\hline \multirow{3}{*}{$\begin{array}{l}\text { Air perme- } \\
\text { ability }\end{array}$} & Pearson Correlation & -0.352 & -0.281 & $\left.-0.690{ }^{(* *}\right)$ & -0.307 & $-0.631\left(^{*}\right)$ & -0.266 & -0.443 & 1. 000 \\
\hline & Sig. (2-tailed) & 0.198 & 0.310 & 0.004 & 0.266 & 0.012 & 0.338 & 0.098 & \\
\hline & $\mathrm{N}$ & 15 & 15 & 15 & 15 & 15 & 15 & 15 & 15 \\
\hline
\end{tabular}

* Correlation is significant at the 0.05 level (2-tailed).

** Correlation is significant at the 0.01 level (2-tailed).

Table 6

\begin{tabular}{|c|c|c|c|c|c|c|c|c|}
\hline \multicolumn{9}{|c|}{ ONE-SAMPLE KOLMOGOROV-SMIRNOV TEST NPAR TESTS } \\
\hline & $\begin{array}{c}\text { Dimensional } \\
\text { changes } \\
\text { (length) }\end{array}$ & $\begin{array}{c}\text { Dimensional } \\
\text { changes } \\
\text { (width) }\end{array}$ & Mass & $\begin{array}{l}\text { No. of } \\
\text { wales }\end{array}$ & $\begin{array}{l}\text { No. of } \\
\text { rows }\end{array}$ & Thickness & $\begin{array}{l}\text { Water vapor } \\
\text { permeability }\end{array}$ & $\begin{array}{c}\text { Air } \\
\text { permeability }\end{array}$ \\
\hline $\mathrm{N}$ & 15 & 15 & 15 & 15 & 15 & 15 & 15 & 15 \\
\hline \multirow{2}{*}{$\begin{array}{c}\text { Normal parameters } \\
(\mathrm{a}, \mathrm{b})\end{array}$} & Mean & 2.5807 & 5.0347 & 195.00 & 140.600 & 164.300 & 1.15967 & 33.4653 \\
\hline & Std. Deviation & 1.2053 & 3.1382 & 56.4800 & 12.6225 & 38.6189 & 0.22933 & 3.83745 \\
\hline \multirow{3}{*}{$\begin{array}{l}\text { Most extreme } \\
\text { differences }\end{array}$} & Absolute & 0.155 & 0.224 & 0.126 & 0.179 & 0.144 & 0.139 & 0.139 \\
\hline & Positive & 0.155 & 0.224 & 0.126 & 0.164 & 0.144 & 0.095 & 0.119 \\
\hline & Negative & -0.133 & -0.137 & -0.124 & -0.179 & -0.092 & -0.139 & -0.139 \\
\hline \multicolumn{2}{|c|}{ Kolmogorov-Smirnov Z } & 0,602 & 0.869 & 0.487 & 0.694 & 0.559 & 0.539 & 0.539 \\
\hline \multicolumn{2}{|c|}{ Asymp. Sig. (2-tailed) } & 0,862 & 0.437 & 0.972 & 0.720 & 0.914 & 0.934 & 0.934 \\
\hline
\end{tabular}

$\mathrm{a}-$ test distribution is Normal; $\mathrm{b}$ - calculated from data.

Thickness $=2.481-0.032 \times$ air permeab -

$$
-0.00 \times \text { water_vap_permeab }
$$

Mass $=f($ No. of wales Do, No. of rows Dv)

Mass $=543.9-2.35 \times$ no. of wales $-0.11 \times$ no. of rows
The residues obtained values (figures 3-5) demonstrate that the established models are adequate. Distance between axis and values determine the

residual value of the predictable regression. 


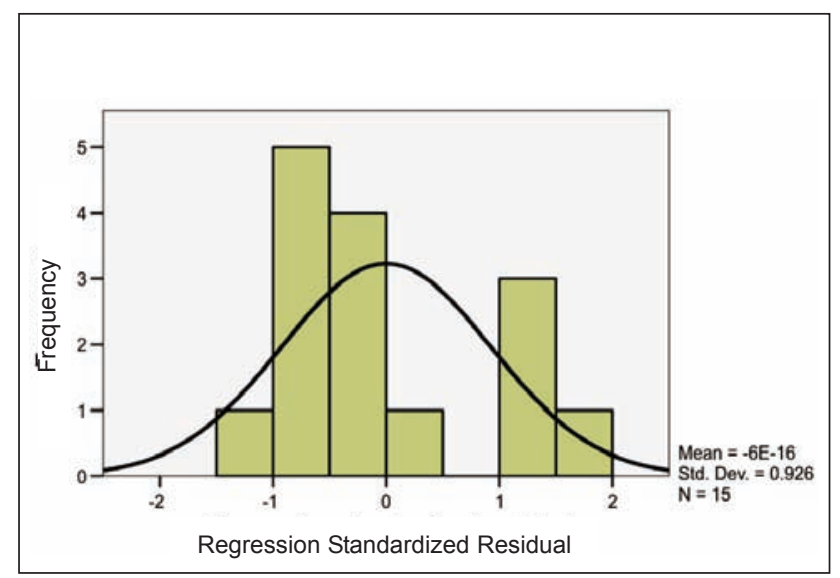

a

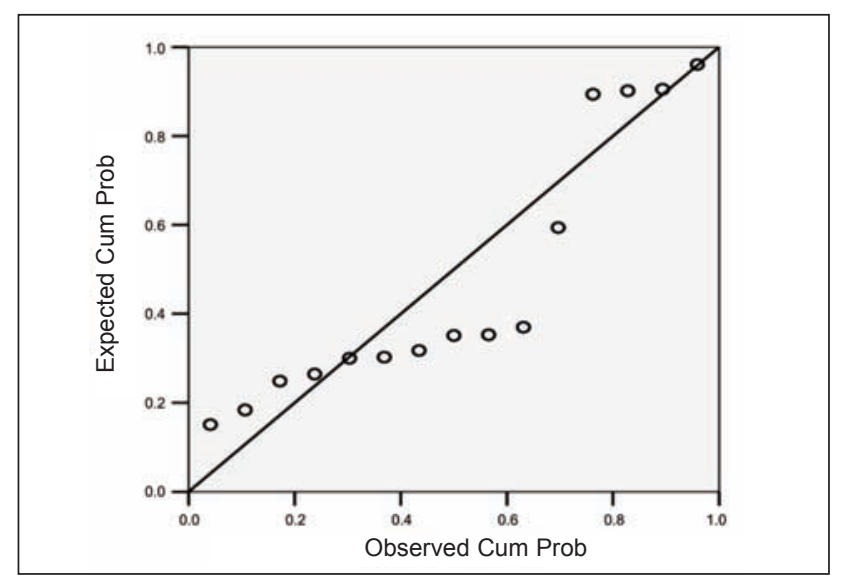

b

Fig. 3. The variation of mass depending on water vapour permeability and water permeability: $a$ - standardized residuals histogram; $b$ - residue distribution depending on axis

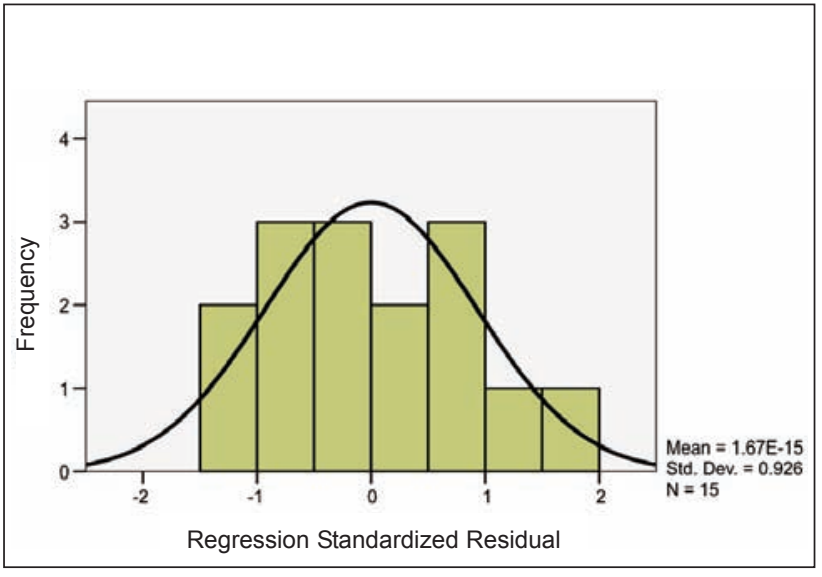

a

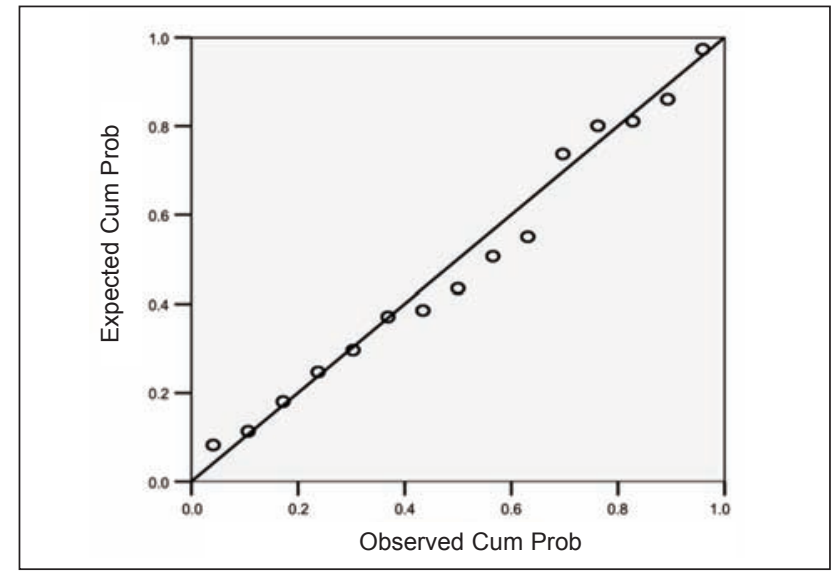

b

Fig. 4. The variation of thickness depending on water vapour permeability and water permeability: $a$ - standardized residuals histogram; $b$ - residue distribution depending on axis

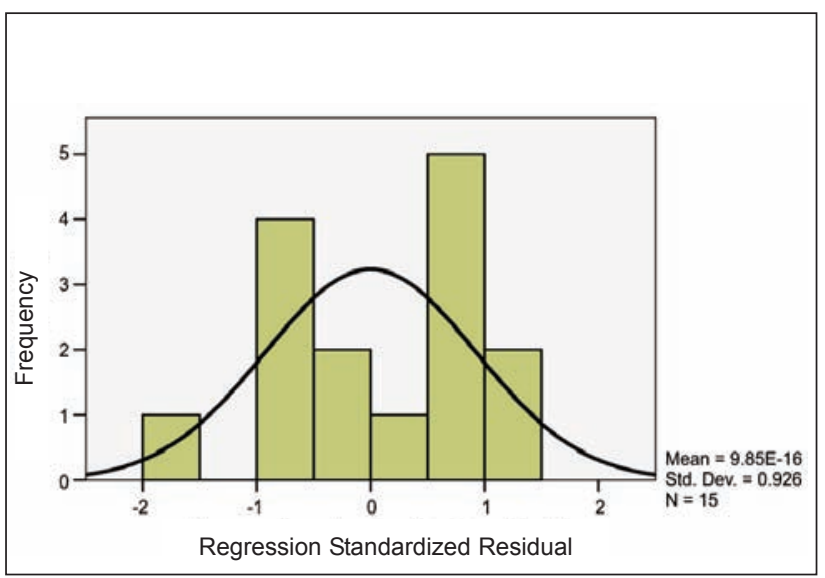

a

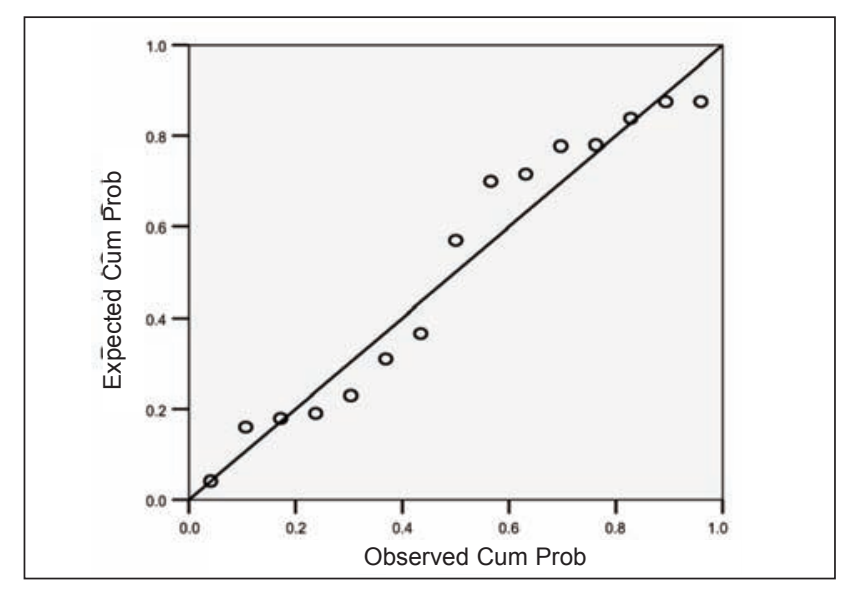

b

Fig. 5. The variation of mass depending on no. of wales and no. of rows: $a$ - standardized residuals histogram; $b$ - residue distribution depending on axis

\section{CONCLUSIONS}

The values of structure parameters characterize a certain state of the knitted fabric. Starting with manufacturing process of fabric, using knitting machine, up to use the product structure, parameter values are changed, the level and direction of variation depending on many factors.

The design algorithm ensures the integration of the interactive textile element into the anatomical shape of product so as the performance of the entire 
bio-mechanical or physiological parameters monitoring system to be assured.

Choosing the optimum textile structures aims to understanding the causes and mechanisms underlying the maintenance of health, functional elements and use requirements field.

\section{ACKNOWLEDGEMENT}

The study presented was carried out under PN 16340208 "Innovative monitoring-maintenance systems, of human body operating parameters" national project, in the framework of Nucleus Research and Development Programme.

\section{BIBLIOGRAPHY}

[1] Noriaki Kano, Attractive quality and must-be quality, In: Journal of the Japanese Society for Quality Control, pp. 39-48

[2] Center for Quality of Management Journal, David Walden, accesat http://www.waldenfamily.com/public/cqmjournal/2-4-Whole-Issue.pdf

[3] SubrataDasgupta, Design theory and computer science, Cambridge University Press, ISBN 978-0-521-11815-6, 2009

[4] P.J.W tenHage., T. Tomiyama, Intelligent CAD System, EUROGRAPHICS, 1987, ISBN 13:978-72947-8, Switzerland

[5] S. Lam Po Tang, Recent developments in flexible wearable electronics for monitoring applications, School of Textiles and Design, Heriot-Watt University, Netherdale, In: Transactions of the Institute of Measurement and Control 29, 3/4 (2007) pp. 283-300

[6] Pan J., and Tompkins W.J., A real-time QRS detection algorithm,In: IEEE Trans. Biomed. Eng., vol. BME-32, pp. 230-236, 1985

[7] Stewart J., Vital Signs and Resuscitation, Landes Bioscience, Texas USA, 2003, ISBN: 1-57059-671-9

[8] Varshney U., Pervasive Healthcare Computing, Springer LLC, 2009, ISBN: 978-1-4419-0214-6

[9] Yang Xiao and Hui Chen (Editors), Mobile telemedicine: a computing and networking perspective, CRC Press, ISBN: 978-1-4200-6046-1, 2008

[10] Boros M., Monitoring in Medical Practice - Basic Medical Skills, Institute of Surgical Research University of Szeged, Medical School Hungary, Innovariant Ltd. 3 Textilgyári Rd., H-6725 Szeged, 2007, ISBN 963-482-787-X

\section{Authors:}

\section{EFTALEA CĂRPUS \\ CARMEN MIHAI \\ ANGELA DOROGAN \\ IULIA BIRLIBA}

The National Research \& Development Institute for Textiles and Leather 16 LucretiuPătrăşcanu Street, 3 District, 030508, Bucharest

\section{Corresponding author:}

\section{EFTALEA CĂRPUS}

e-mail: eftalea.carpus@certex.ro 


\section{The management of consumers' rights protection in computerised marketing in textiles and leather industry}

\section{REZUMAT - ABSTRACT}

\section{Protecția drepturilor consumatorilor în marketingul computerizat din industria de textile și pielărie}

Lucrarea abordează problemele și rezultatele cercetării de frontieră pentru managementul ce vizează elementele de marketing: cerințele de protecție a drepturilor consumatorilor prin procesarea marketingului on-line, analize și tendințe pentru caracteristicile strategiilor de marketing corporativ. Metodologia de cercetare este dezvoltată cu scopul de a motiva angajamentul de marketing on-line, respectând drepturile și protecția consumatorilor din domeniul industrial și al consumului de textile și produse de pielărie. S-a ajuns la concluzia că managerii de marketing din industria textilă și a pielăriei au nevoie de un nou tip/model de consiliere și orientare, pe baza procedurilor persuasive care ajută cariera acestora prin cunoaștere avansată în regim computerizat a modului de protecție a drepturilor consumatorilor.

Cuvinte cheie: industria de textile și pielărie, marketing computerizat, drepturile consumatorilor, baza de cunoștințe, management, globalizare

The management of consumers' rights protection in computerised marketing in textiles and leather industry

The paper draws upon issues and results of the management frontier research about marketing elements regarding: the requirements of consumers' rights protection which are at the basis of on-line marketing, the characteristics of the analysis and trends from the corporate marketing strategies. The research methodology is developed aiming at motivations for the on-line marketing commitment regarding consumers' rights protection in textiles and leather. We have reached the conclusion that marketing managers in textiles and leather need a new type/model of counselling and orientation, based on persuasive procedures helping their careers advance based on knowing the computerised consumers' rights protection mode.

Keywords: textiles and leather industry, computerised marketing, consumers' rights, knowledge cohort, management, globalisation

\section{INTRODUCTION}

During the last years, the society underwent fundamental structural changes in terms of relations between citizens and its representative entities. This process is due mainly to the unseen development of modern technologies, especially the informational ones. The textile and leather industry is representative for the rights of consumers regarding quality, quantity and product safety. The stressed mobility of market phenomena, specific to the modern textiles and leather economy and materialized in an unseen dynamism of trade exchanges, the fast and unpredictable transformations of the merchandise request, of the request-offer report and the level of prices, force the companies to total and immediate involvement in the market mechanism. More and more and in most cases one can notice that marketing, as a science and an instrument, is undergoing a conception change at the managers' level regarding the consumers' rights protection in textiles and leather correlated with the responsibilities of the organisations towards the consumers. The paper draws upon issues of management frontier on marketing elements regarding the requirements of the consumers' rights protection which subtend the on-line marketing operations, the analysis and trends of the corporate marketing strategies.

\section{EXPERIMENTAL WORK}

The internet as globalisation generation factor

The beginning of the $21^{\text {st }}$ century provides a new complex and innovative evolution table for the world society. The globalisation phenomenon is unstoppable. The adhesion to globalisation is the result of a psychological attachment to an unstoppable and undefeatable phenomenon, which, at least currently, at conceptual level has no physical and material clearly defined horizon, as final purpose, but also has no corresponding opposite alternative of principle. Globalisation can be an ideal, as long as its horizon lies within utopia, and the stubbornness in applying it relies on a certain generalised idea, virtually centralised, issued and lead based on focused management, of a new integrative essence, applied by the great lines and trenches of the world. A new human interaction has been identified, with a high degree of dominance, which has "effects and reactions", which lead or determine new concretely developments. 
Globalisation is caused mainly by three factors: a) technological globalisation; b) political globalisation and c) economic globalisation. These three catalyst areas determine reconsidering, respectively losing geographical distances, they facilitate the crossing of any type of frontier, and they formalize (build) economies at unsuspected distances by generalising complementarities without any restrictions, they concentrate various socio-cultural relations. The increasing potential of the internationalisation of relations, the democratic causal dependencies, the environment problems, the reconsidered social and security deficits, to which we can add the de-responsibility of organisations towards consumers, modify visibly the legal and administrative attitudes, respectively the issues related to consumers' rights protection [1]. Event the Internet appeared in the late 60's, the Web was created only in March 1989. Tim Berners-Lee, the creator of the Web, while working at CERN, the European Laboratory for Particle Physics in Geneva, had to find a way for sending information to the researchers in high energy physics, located in various geographical areas. To this extent, he proposed a hypertext system for communication between computers. The first public use of the Web occurred in January 1992 in Geneva, Switzerland, where researchers had access to Web data from the Web site of CERN. In April 1993, almost one year and a half after introducing the $\mathrm{Web}$, there were $60 \mathrm{Web}$ servers. Nowadays the number of servers is estimated at millions. During the last three years, the Web developed explosively and it is not limited only to scientific information exchange between researchers. The business world uses the Web for promoting products, but also for competitiveness, by deliberate responsibility or de-responsibility of the organisations towards the consumers and their rights. The fundamental structural changes in the relations between consumer citizens and the entities within society are due especially to the unseen development of information technologies and on-line marketing. Their impact is experienced in all sectors, i.e. in textiles and leather, public and private, individually and at human community level from much diversified society structures. "Marketing is a business philosophy which sees the key to success in business in satisfying customers and recommends using management practices which help in identifying and solving the clients' requests" [7]. Each historical period requests the company to adopt a new concept in establishing the necessary objectives, strategies and tactics. "A success formula of a firm for a certain period of time will not function with the same chances and results in the next stage" [8]. Robert L. King [5] defined a synthetic phasing of marketing: production-oriented (1900-1930); sales-oriented (1930-1950); marketing-oriented (1950-2000); social-oriented [6]. The evolution of on-line marketing and strategic marketing concept faces constant barriers in the planning of smooth availability of a specific organisational culture which could formalize the corporate awareness of organisations' responsibility in consumers' rights protection. Despite the importance and the central role of marketing planning in the profit gaining process, there are few research studies for determining the way of corporate interpretation and understanding of the on-line operational correct implementation terms for the market programmes characterised by managerial feasibility i.e. trust or conviction that the transparent and ethical functioning of producer-sellers does not influence the survival of firms, companies, corporations etc. The specialty literature provides large consensus on the difficulties and barriers met in marketing planning, materialized in two dimensions: cultural/political barrier and cognitive barrier. A series of factors have been identified, with a strong influence on the capacity of the company to set forward and carry out a quasi-complete planning process of the marketing activity, including the responsibility in consumers' rights protection; these factors are generally known as culture [10]. Paradoxically, the organisational cultures can also become barriers for the development process, since their horizon is focused on the past, a situation where the internal mechanisms they have are unable to face change. A process of marketing activity planning is not a simple sequence of operational stages; it includes a set of values and hypothesis which are an integrated part of the whole process, expressed systemically. Likewise, an organisation does not involve only a conglomerate of people and resources, but it also includes specific values and hypothesis which defined its specific culture and climate, a context where it must always withstand the de-responsibility aggression of forcing consumption by ignorance. Once on-line marketing developed significantly, a type of barriers in marketing planning is the cultural one, known as cognitive dimension. The hypothesis that the knowledge process has special importance in the success of marketing planning becomes very acceptable because all other areas would float in abstract nothingness without the "anchor" of knowledge [11].

\section{THE RESEARCH METHODOLOGY ON MOTIVATIONS FOR ON-LINE MARKETING COMMITMENT REGARDING CONSUMERS' RIGHTS PROTECTION IN TEXTILES AND LEATHER}

It is accepted that managers in textiles and leather, once having a specialisation / position, mainly stay in a professional pseudo-status-quo which holds their corporate concerns regarding the responsibility of the organisations they manage in terms of consumers' rights. The market in textiles and leather, in the dynamics or the context imposed by obtaining competitive advantages in the new knowledge-based economy, more and more visibly installed in the society, does not offer locations, segments or opportunities for constant use of the managerial force from the aforementioned status-quo. Consequently, there is a real need for a transformation framework for initiating and training managers and/or specialising them in 
order to answer the need of compatibility/correlation of the education system (even "second life" type), of the management training system with the dynamics of the management market for marketing. On the other hand, the "lethargy" / the lack / the difficulties in motivation hold the managers in a lagging status, between professional limits and limitations which frequently are eroded morally and operationally in the organisation and leadership processes. In the given context, it was proceeded to conceive an action for setting up a theoretical and practical methodology for developing the specific institutional instruments with open access and participation parts for higher continuous managerial training, in rhythm, congruence and compatibility with the dynamic transformations and evolution of the management market within computerised marketing. The tangible outcome of such a commitment, based on the methodological development for institutional management proposed for wider access and participation to training, is the increase of employability for marketing managers. In this context, the theoretical research and the practical knowledge was carried out in 2011-2013 on 144 firms, members of Romanian Employers, i.e. textiles and leather firms, based on random sampling statistics, characterisations for the ensemble of activities, methods and techniques which seek to satisfy the requests of clients and to satisfy these requests with products and services, which by their characteristics, quality, prices and availability in time and places where they are requested, can provide advantages under the label of organisational responsibility regarding consumers' rights (figure 1).

The implementation of new solutions of methodological and institutional type by configuring a feasible / sustainable flow for useful access and participation in formalizing the on-line marketing management ensures equal opportunities for all for repositioning managers in the labour market and in the modern organisation and management process, with a stake on sustainable results in the responsibility of managers and organisations regarding consumers' rights.

\section{RESULTS AND DEBATES}

Informal and non-formal education for increasing the responsibility of managers and organisations regarding consumers' rights in textiles and leather

One can note that the cultural evolution sequences are assumed between generations to the extent of the endogenous capability of trans-global transferability which they have to prove in time. Marketing education is melted in the learning process.

Schooling is almost extinct, in the context that education gains operational priority. Schooling is just a personal instrument for immersion into knowledge for education. The vocational training for industry and business, respectively for marketing, represents nonformal education. We believe that marketing education needs reconciliation with the exogenous cultural realities, which are quasi-unlimited and in which currently humans are dwelling. The increase of employability of the persons undergoing higher professional education and training, as well as the increase of the training level of the managers employed in the labour market, can be achieved by the institutional and methodological development of the access and participation of lifelong higher professional training, from basic level (graduate) up to the integrated management level, in the context of passing towards a knowledge-based society. This objective derives from the generic/practical requirements of the knowledgebased society, where intangible assets tend to prevail and the staff with basic higher education studies must be ensured up to the integrated management level. One can note that the professional higher education and training system for knowledge referring to the responsibility of organisations regarding consumers' rights is inadequate as related to the labour market dynamics.

The variety of discrepancies represents obstacles in getting and keeping jobs for the people that aim at higher training in marketing. For instance, one can 
note that globally there is a quasi-constant contacting/re-extension of the labour market in a specific dynamic. The various higher education forms, including the marketing sector, participate to the aforementioned strategic approach for the usual organisation and management methods and techniques. The crossing of such a frontier is positive for new relations with the management of responsibility. The investment in human capital and in the lifelong higher professional training in knowledge for the responsibility of managers and organisations regarding consumers' rights leads to:

- creating the environment for promoting entrepreneurial attitudes and abilities via lifelong higher professional training at all levels for marketing managers;

- revising the incentives and motivations for increasing the inclusion rate in lifelong higher professional training;

- eliminating/reducing the lagging situations of management self-content and avoiding drop out, acting innovatively for improving and diversifying the lifelong higher professional training offers, by new concepts, respectively by anchoring the competences in the area of confidence in organising and managing the knowledge for the responsibility of managers and organisations regarding consumers' rights;

- developing innovative methods for managerial training by using modern technologies and telecommunications, creating abilities for using information techniques, including at the level of managerial training in the knowledge for the responsibility of managers and organisations regarding consumers' rights.

There is a real need for inputs in developing a lifelong higher professional training system, with an appropriate level of involvement, able to ensure employability, adaptability and mobility/flexibility of the management labour force in marketing. The focus on a knowledge-based society requires a transformation in the attitude of the management human resources, by encouraging the managers to acquire new competences, including responsible confidence and to accept occupational mobility. Thus, performance and higher quality of the training offer for management in marketing are being promoted, ensuring its relevance as related to the abilities, knowledge and needs of the managers. The improvement of the position of managers on the labour market and in terms of knowledge for the responsibility of managers and organisations regarding consumers' rights is obtained by collecting frontier knowledge, acquiring new competences and by increasing productivity in organisation and management.

The management of the responsibility of organisations regarding the protected consumers' rights contributes to developing the human capital and to increasing competitiveness. In fact, the management of computerised marketing ensures, for the first time, measurement formulae of intangible assets and of knowledge and contributes to developing the general intangible assets, and the proposed and implemented creation contributes to formalizing the intangibilitybased society. The specific objectives of the management of computerised marketing in textiles and leather, in close connection with the management of the responsibility of organisations regarding the protected consumers' rights aims at conceiving, designing, implementing, testing, developing and disseminating some new instruments, methodologies and efficient and performing formulae for access and participation to lifelong management training. The operational objectives refer to:

- promote the access and participation of managers at management knowledge programmes targeted to make them obtain complete and updated qualifications in the area of modern organisation and management, based on knowing the computerised mode for protecting consumers' rights;

- promote, create awareness, inform and disseminate the benefits of frontier management programmes in textiles and leather;

- extended dissemination, with general character, of the optimum and efficient methodological formula for ensuring access and participation to management training programmes, based on knowing the computerised mode for protecting consumers' rights in textiles and leather.

The correlation between the need for the training process and the technological changes in textiles and leather is given by the dynamics of enterprises, the tendencies and the impact of the technical process on marketing. One can note that is highly necessary to change the mentality regarding the management training in marketing by increasing awareness on the importance of lifelong learning, including the for the connection to the management based on knowing the computerised mode for protecting consumers' rights (figure 2 and figure 3 ).

The notes in figure 3 mean:

$\left(L_{f}\right)=$ labour force;

$\left(E_{s}\right)=$ education system based on knowing the computerised mode for protecting consumers' rights in textiles and leather;

$\left(\mathrm{PT}_{\mathrm{s}}\right)=$ the professional training system management, based on knowing the computerised mode for protecting consumers' rights in textiles and leather; $\Delta\left(L_{f}\right)=$ dynamics of the labour force in textiles and leather;

$\Phi\left(E_{\mathrm{s}}\right)^{+} ; \Phi\left(\mathrm{PT}_{\mathrm{s}}\right)^{+}=$positive correlation of the education system, respectively of the management training system with the labour force, based on knowing the computerised mode for protecting consumers' rights in textiles and leather;

$\Phi\left(\mathrm{E}_{\mathrm{s}}\right)^{+} ; \Phi\left(\mathrm{PT}_{\mathrm{s}}\right)^{-}=$negative correlation of the education system, respectively of the management training system with the labour force, based on knowing the computerised mode for protecting consumers' rights in textiles and leather; 


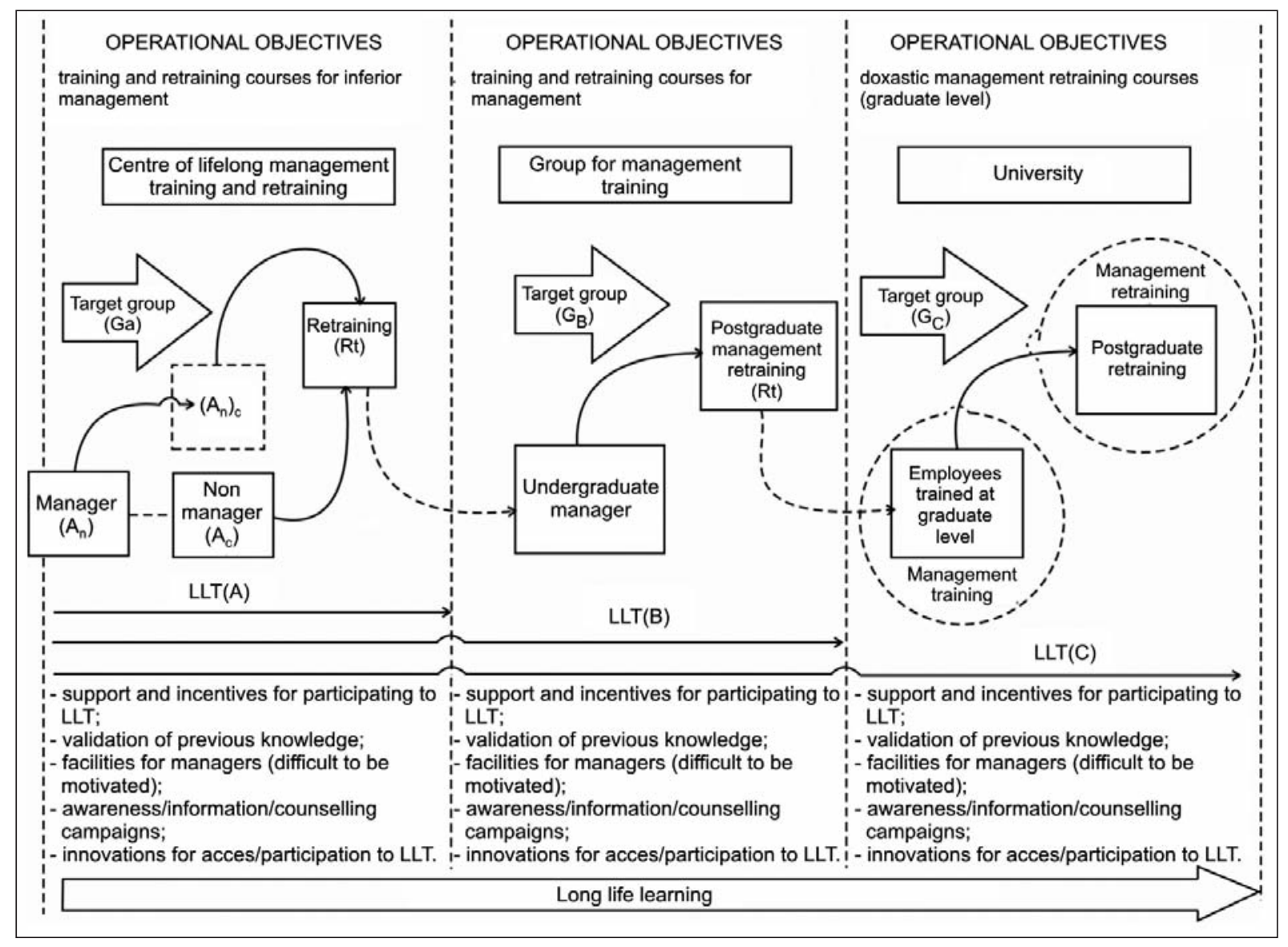

Fig. 2. Stages of management training (low manager, management retraining, textiles and leather management)

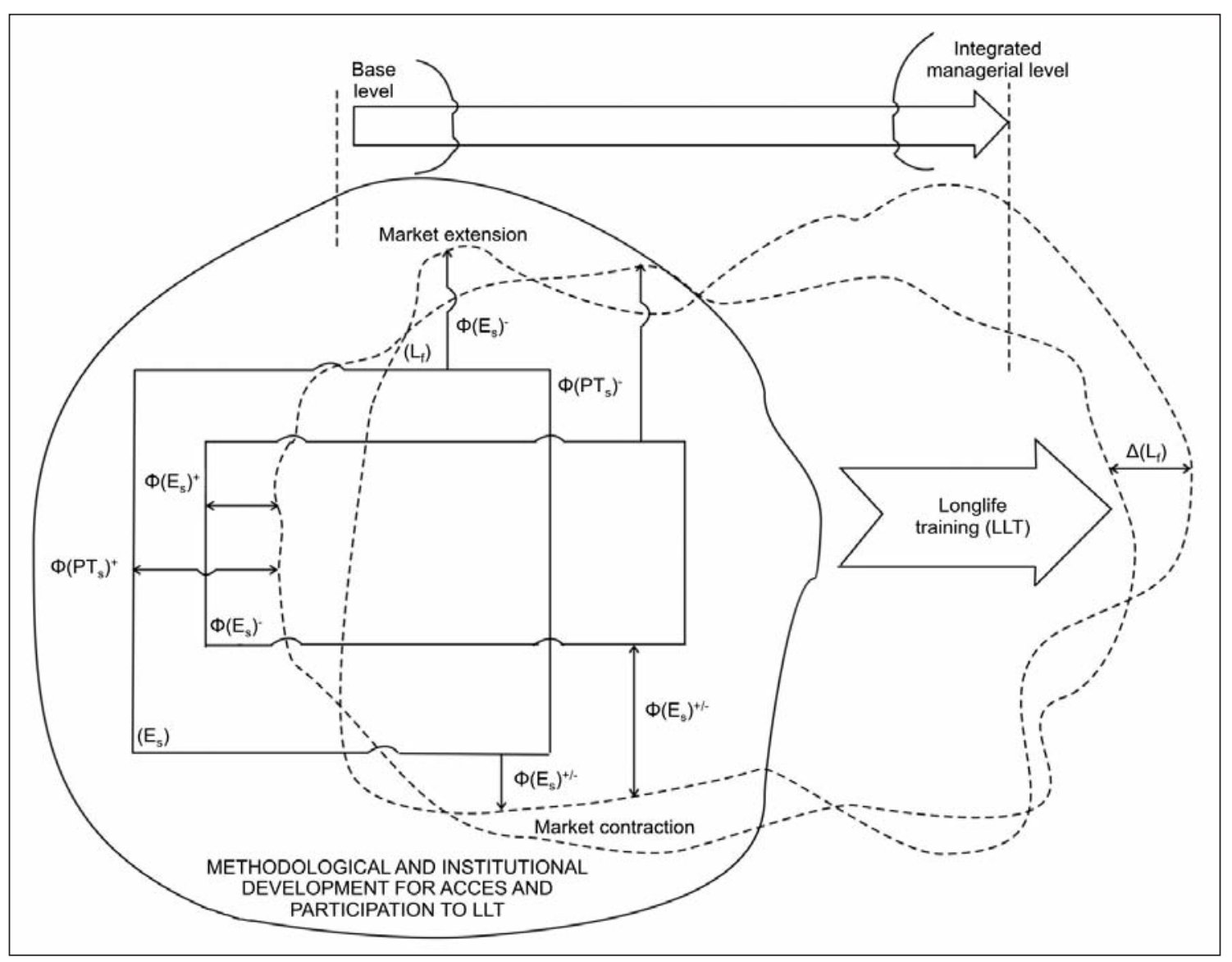

Fig. 3. Evolutionary correlation and inter-correlation for the connection with textiles and leather management 
$\Phi\left(E_{S}\right)^{+/-} ; \Phi\left(P T_{s}\right)^{-/+}=$mixed correlation of the education system, respectively of the management training system with the labour force, based on knowing the computerised mode for protecting consumers' rights in textiles and leather.

It is useful to design a new original model for developing and diversifying the management training offers.

It is interesting to set a complex quasi-tangible algorithm for the immersion of managers in the lifelong training process, based on knowing the computerised mode for protecting consumers' rights. It is based on the managers' transitory access to higher professional training, supported by presence explanations, in second-life. For quantifying the monitoring elements aiming at corrective interventions (by feed-backs), we can design a model for measuring the intangible assets in the textiles and leather management training (DMT) in order to optimally scale and simplify the knowledge process by synthesizing the elements which contribute crucially in creating /acquiring new competences by retraining in a computerised system the marketing managers towards a higher level than the one already held. The performance evaluation of DMT is done by means of audit and self-audit, designed for training programmes, institutions, processes, new competences, results, professional added values and the insertion on the labour market of the retrained managers. This quasi-ongoing computerised system for the evaluation of DMT can be created using "data mining" databases. Thus, there is a real need for a new type / model of counselling and orientation to the marketing managers, with persuasive procedures, by real discovery and understanding of the new directions that the careers of the subjects have to advance on, based on knowing the computerised mode for protecting consumers' rights in textiles and leather.

The dissemination regarding the modalities for computerised training/retraining of marketing managers can be done using new types of offers, stressing "the getting away" of managers from restrictive didactical and pedagogical problems, which must be simplified, synthesized and turned efficient. "The manager-oriented approach" is integrated with the transparent functioning of the mechanisms in order to reach results and with the support provided along each programme based on knowing the computerised mode for protecting consumers' rights, in order to finalize successfully the lifelong professional training in marketing management. Lifelong learning creates the premises for informal education. The hegemony of formal education in schools and universities starts shaking. It is possible that there are more and more educators who tend to become constructivist agents, contributors to the specialised processes for actiontype training for life. The computerised marketing school will shift from the endogenous educational area to the exogenous one, leaving enough room for the individual in its endogenous reality in order to make operational the immersion into learning. In such an evolutionary context, the informational technologies used in marketing determine positive consequences (efficiency), but also negative ones (by depersonalization) in the trans-generation cultural process. Anyway, the future of education based on knowing the computerised mode for protecting consumers' rights in textiles and leather will be much more diversified, respectively varied and transactional.

\section{Number evolution (KC) in finite time lapses}

Among the companies studied within Romanian Employers, i.e. textiles and leather firms, we have conceptualized the expression of knowledge cohort, related to knowing the computerised mode for protecting consumers' rights. For a time lapse $\mathrm{T}_{\mathrm{i}} \mathrm{EE}\left(t_{i} ; t_{i+1}\right)$ having the size:

$$
T_{i}=t_{i+1}-t_{1}
$$

we consider an evolution of the knowledge cohort (KC), out of which a number $N_{t}$ of knowledge survives, i.e. is selected, thus exploited and capitalized. If $N_{t}=$ constant, we consider the condition $(\mathrm{KC})$ as in a deadlock. If $N_{t}<0$, the evolution is negative and for $N_{t}>0$ we register the increase of the operational knowledge level (knowledge data). The term "cohort" (C) in (KC) suggests the transitivity of the multitude of data from one horizon to another, from a condition to another, in given time lapses, occasions upon we extract knowledge elements for the operational process. In this context, it is possible to formalize the "length" dimension of the cohort related to knowing the computerised mode for protecting consumers' rights in textiles and leather, respectively it is possible to identify significance densities which could induce attractiveness for the knowledge data in order to be brought in the operational process. If $t$ is the age of a knowledge datum, $L_{i}=$ individual length (the dimension of a knowledge datum, in terms of size, density, quality, quantity or the significance symbolized as such); $L_{\infty}=$ asymptotic length and $t_{e}=$ the moment for starting the knowledge data exploitation stage, it is possible to express the properties of a $M_{K C}$ model. The model marks the differences between the terms $L_{\infty}$ and $L_{i}:$

$$
M_{K C}=L_{\infty}-L_{i}
$$

The general expression of the properties of the exponential model is:

$$
\left(L_{\infty}-L_{i}\right)=\left(L_{\infty}-L_{a}\right) \mathrm{e}^{-K\left(t-t_{a}\right)}
$$

where $K=$ growth parameter and $t_{a}$ and $L_{a}$ represent initial conditions. For $t_{a}=t_{0}$ and $L_{a}=0$ it results:

$$
\left(L_{\infty}-L_{i}\right)=L_{\infty} \mathrm{e}^{-K\left(t-t_{0}\right)}
$$

In systemic vision (von Bertalanffy-type models) the expression for $L_{i}$ is:

$$
L_{i}=L_{\infty}-\left(L_{\infty}-L_{a}\right) \mathrm{e}^{-K\left(t-t_{a}\right)}
$$


For $t_{a}=t_{0}$ and $L_{a}=0$ it results:

$$
L_{i}=L_{\infty}\left[1-\mathrm{e}^{-K\left(t-t_{0}\right)}\right]
$$

Transitory knowledge must be organised and managed. Otherwise, the multitude of knowledge data, potentially useful for making operational the decisional processes related to knowing the computerised mode for protecting consumers' rights in textiles and leather, stays inert, marked by its own lifecycle on specific time lapses.

Probability of frontier coherence for knowing the computerised mode for protecting consumers' rights in textiles and leather and opinions in the management decision for electronic marketing

The management related to knowing the computerised mode for protecting consumers' rights in textiles and leather cannot be separated from epistemology. In a practical context, the purpose of managerial knowledge is fulfilled with the potential highlight of attitudes or of attitude flows, which are to be found represented in organisation and management for protecting consumers' rights as accurately as possible when applied. Consequently, there is the need for passing from the theory of standard probabilities to a theory of non-standardized probabilities, by attitudinal and infinitesimal observing and quantifying. The design of theoretical instruments on the one hand and of logical instruments on the other hand, which are to work in decomposing attitudes, is a complex operation counting on evaluating/examining management knowledge and beliefs related to knowing the computerised mode for protecting consumers' rights. At the same time, the managers from computerised marketing are perceived/considered as essential/latest sources of potential knowledge for organisation and management, yet marked by their management beliefs, which are covering their own actions and outlooks. The exploration of propositional language can be an instrument for examining the managerial coherence of opinions in management decisions related to knowing the computerised mode for protecting consumers' rights in textiles and leather. This action-type proposal is a premiere contribution in the sector. We estimate that simple trust in the management related to knowing the computerised mode for protecting consumers' rights starts as a process and a phenomenon for quantifying opinions in decision-making from entry propositions (figure 4).

The power of quantification of at least one model of simple trust is significant for the potential level of knowledge/proving knowledge stored in the managerial source (as manager in computerised marketing). Consequently, in the current management model, at the marketing manager we can find formal models related to a) the epistemic of organisation and management, respectively $b$ ) the operational character related to knowing the computerised mode for protecting consumers' rights in textiles and leather. The nesting of information/knowledge in the managerial source can be done by 1) extensions and 2) revisions of the related epistemological fund. Reaching coherence means, in our opinion and in the present context analysis, passing from one model of subject probability (by revelation and probability mix) to opinion (from vague, with qualitative, comparative and quantitative threads) in organisation and management related to knowing the computerised mode for protecting consumers' rights in textiles and leather. In other words, a manager can consider the fact that at any time when he is sure that his organisational and management proposals are explicit, he should believe/be persuaded that they are simultaneous and implicit. The set of propositions allowing the explanation process is marked by a logical closing of implicitly. The management commitment is supported in an infinitesimal way, implicitly by atomic/atomized propositions (figure 5).

Yet, the conception, to state that the set of explanation propositions does not register contradictions if the respective proposition can be integrated in a model, which validates their instrumentality, is also important. Within this framework we must induce the

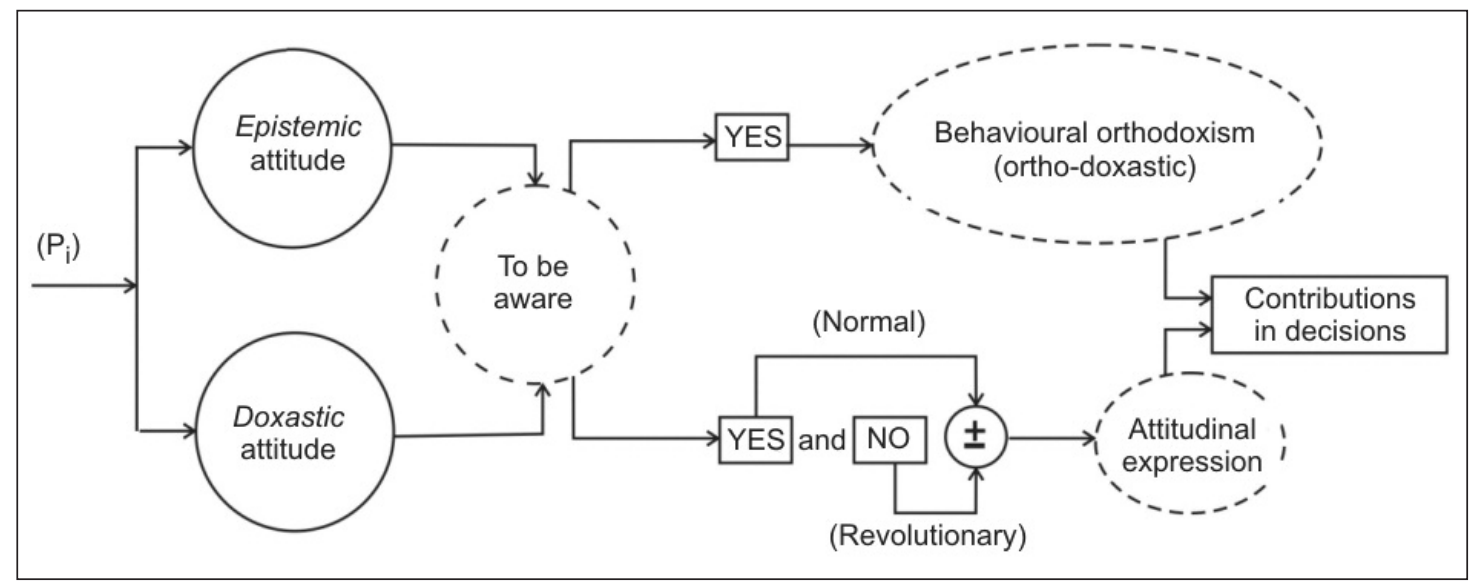

Fig. 4. Model of simple trust involved in a contributory manner in decision making; $\left(P_{i}\right)=$ entry proposition 


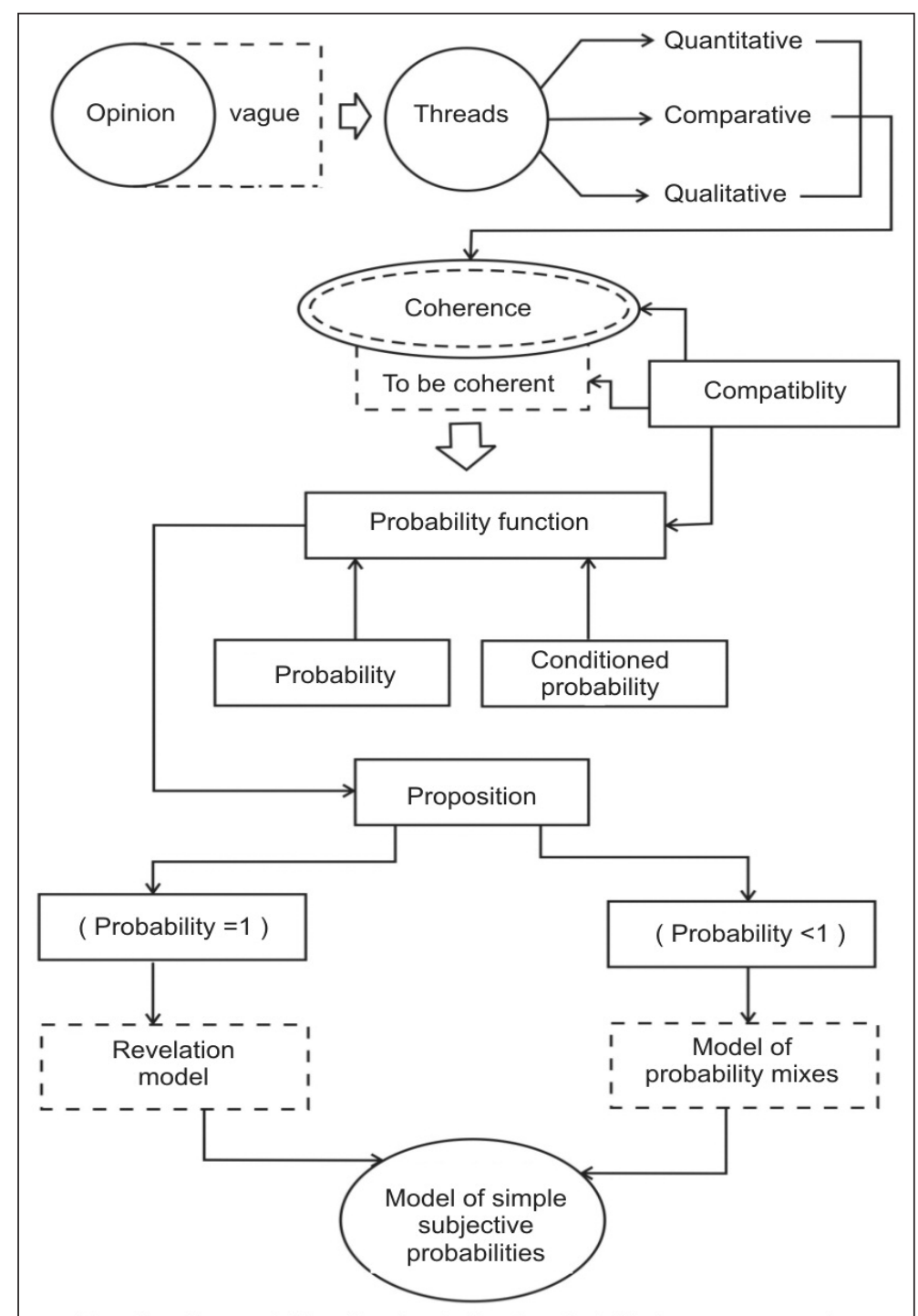

Fig. 5. Algorithm for modelling the simple trust probability in management decision
Consequently, the coherence of opinions in management decisions in textiles and leather industry approach depends on a certain non-standardized probability. The presence of a flow of management propositions in the attitudinal flow of the manager increases the degree of formalization of the decision area in organisation and management related to knowing the computerised mode for protecting consumers' rights in textiles and leather. The management of management erosions or constructions in computerised marketing becomes mandatory, perceiving the need for a distinct organisation and management of these types of processes/phenomena.

\section{RESULTS}

Knowing the computerised mode for protecting consumers' rights is marked by a logical closing of implicitly. We can conclude that the purpose of managerial knowledge, in the practical context of computerised marketing, is fulfilled with the potential highlight of attitudes or of attitude flows, which are to be found represented in organisation and management for protecting consumers' rights in textiles and leather as accurately as possible when applied. Consequently, there is the need for passing from the theory of standard probabilities to a theory of nonstandardized probabilities, by attitudinal and infinitesimal observing and quantifying. Lifelong learning creates the premises for informal education. The hegemony of formal education in schools and universities starts shaking. It is possible that there are more and more educators who tend to become constructivist agents, contributors to the specialised processes for action-type training for life. The computerised marketing school will shift from the endogenous conception of propositional extension by formalizing a set of "quasi-atomic propositional entries" in order to obtain an input-output model of opinions related to knowing the computerised mode for protecting consumers' rights in textiles and leather. The relational alternatives are transitory/transitive, reflexive in an area formally closed of the management decision in computerised marketing (figure 6). educational area to the exogenous one, leaving enough room for the individual in its endogenous reality in order to make operational the immersion into learning. In such an evolutionary context, the informational technologies used in marketing determine positive consequences (efficiency), but also negative ones (by depersonalization) in the transgeneration cultural process. 


\section{BIBLIOGRAPHY}

[1] Gâf-Deac I.I., New juridical horizons and globalization, In: Infomin Publishing House, Deva, 2002, p. 48

[2] Burney B., The concept of cyber-crimes, University of Dayton School of Law, 1999

[3] Shaw J., European Community Law, Blackstore Press, London, 1993

[4] Malcom, M. Marketing strategic, Codecs Publishing House, Bucharest, 1998

[5] King R.L., The marketing concept, Science in Marketing, N.Y., 1998

[6] Buell, V.P. A strategic planning approach, Marketing Management London-N.Y., 1984

[7] Hill E., O'Sullivan T., Marketing, Antet Publishing House, Oradea, 1997

[8] Drucker P., Management: tasks, responsibilities, practices, 1973, New York, p. 64-65

[9] Kotler Ph., (col), Principles of marketing, Teora Publishing House, Bucharest 1998

[10] McDonald M.H.B, Marketing plans: how to prepare them; how to use them, UP Oxford, 1995

[11] McDonald, Malcom A., Marketing strategic, Ed. Codecs, Bucharest, 1998

Authors:

IOAN I. GÂF-DEAC ${ }^{1}$

ALEXANDRA ENE 2

EMILIA VISILEANU ${ }^{2}$

MONICA CRISTINA VALECA ${ }^{3}$

IOANA ANDREEA MARINESCU ${ }^{4}$

${ }^{1}$ PhD. Economics \& PhD. Engineering, Senior Lecturer

S. Haret University of Bucharest, University of Pitesti Romanian Academy, Bucharest

${ }^{2}$ PhD. Engineering, Senior Resercher, I Dgr. Sci. Resch

INCDTP, Bucharest

${ }^{3}$ PhD. Engineering, Lecturer

University of Pitesti

${ }^{4}$ PhD. Economics \& PhD. Engineering, Senior Lecturer Bio-Chem. Med. Vet.

S. Haret University of Bucharest

Corresponding author:

IOAN I. GÂF-DEAC

editurafmp@gmail.com

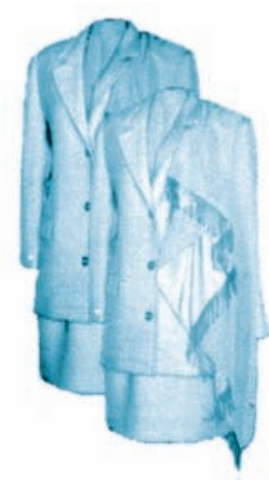




\title{
The evolution of textile and clothing industry in Romania: an analysis from the perspective of imports and exports determinants
}

\author{
DOI: $10.35530 / 1 T .068 .02 .1236$
}

\author{
GABRIEL BRĂTUCU \\ GHEORGHE EPURAN \\ DANIEL ADRIAN GÂRDAN \\ FLOAREA BUMBAȘ
}

\author{
ALEXANDRA ZAMFIRACHE \\ IULIANA PETRONELA GÂRDAN \\ MĂDĂLINA-ADINA (STĂNILĂ) OPRIȘ
}

\section{REZUMAT - ABSTRACT}

\section{Evoluţia industriei textile şi de confecţii din România: analiză din perspectiva determinanţilor de importuri şi exporturi}

Industria textilă și de confecții din România a cunoscut o evoluție interesantă după 1989, caracterizându-se printr-o serie de elemente comune cu evoluția domeniului la nivelul pieței europene și mondiale, existând însă și o serie de factori care influențează în mod specific piața, în general, importurile şi exporturile, în special.

În acest articol, autorii realizează o analiză a factorilor determinanți ai importurilor şi exporturilor de produse textile şi confecții, folosind statistici combinate şi serii de date referitoare la principalele variabile identificate. Concluziile articolului evidențiează posibile direcții de acțiune în vederea optimizării fluxurilor de export, respectiv import, pentru dezvoltarea unor politici comerciale echilibrate în domeniul industriei textile și de confecții.

Cuvinte-cheie: industria textilă și de confecții, importul de produse textile și de confecții, exportul de produse textile și de confecții, PIB, salariu mediu, cursul de schimb valutar, investiții nete în industria textilă şi de îmbrăcăminte

\section{The evolution of textile and clothing industry in Romania: an analysis from the perspective of imports and exports determinants}

\begin{abstract}
The Romanian textile and clothing articles industry has known an interesting evolution after 1989, characterized through a series of elements that are common with the evolution in the field at the level of European or world market, being present however several factors that specifically influence the market in general and imports and exports especially. In this article, authors analyze textile products and clothing articles imports and exports determinants using combined statistics and data series regarding the main identified variables. The article conclusions point out possible courses of action designed to optimize the flow of exports and imports, development of balanced trade policies in the field of textile and clothing articles.

Keywords: textile and clothing articles industry, textile and clothing articles imports, textile and clothing articles exports, $G D P$, average wage, foreign exchange rate, net investments textile products and clothing articles
\end{abstract}

\section{INTRODUCTION}

Into a global framework that is characterizing the world economy evolution in the last twenty years, the clothing articles market is having a richness of products and that is why quality, the notoriety of brands and the price are making the difference between the main producers.

In the last years, there have been published articles and researches referring to the evolution of European countries economies in general and also former-socialist countries, and at the level of a series of approaches, globalization is seen as a determinant factor for the actual economic environment inducing a higher degree of competition in all fields of activity without exception, including textile industry [1-2]. The high competition forced the big companies to reorient their production towards disadvantaged economic regions that are allowing net advantages from the point of view of legislation regulations, fiscal policy, environment protection regulations and the price of the workforce. In this context, Romanian textile industry evolution was influenced in the last years by a number of factors that have been closely related with the evolution of European market but also of international market as well.

After 1989, the textile sector was changing due to the new economic, social and political conditions. There have been structural changes along with quantitative and qualitative changes as well. The clothing articles subdivision of the industry was rising from $28 \%$ in December 1989 to $62.5 \%$ in January 2004 and $44.7 \%$ in January 2015 [3-5].

The Romanian products have been dragged into an unfair competition with products from different countries like Turkey, China, India, Pakistan, Thailand, Mexico etc. that are having a lot of resources in terms of raw materials and financial incentives [3].

At first, the new entered products have been appealing for the Romanian consumers, because of the novelty and the wide range of models, colors and styles, but, in time, it was clear the fact that the real quality of these products was, many times lower than 
Romanian or other west European countries products quality.

The most important characteristic of the clothing articles industry in Romania for all the considered period consists in the fact that it was an important development of the lohn production system, in which Romanian companies became subcontractors of foreign companies, without their own identity on the market (in terms of brand image, visual identity etc.). Because of the lohn system development, also the local textile industry has had a lot to suffer, the local demand becoming very low.

The lohn system was used on a large scale especially by Western European companies that came and invested on the Romanian market because the textile and clothing articles industry represents branches that are intensively using the workforce and the cost associated with it being very important for the competitivity of the products. In a wider perspective, the clothing articles market it is a very saturated one, with a strong competition in developed countries and a very low elasticity coefficient of demand upon income.

Another important factor that was shaping also the evolution of the Romanian textile and clothing articles industry is related to the regulations applied at international level regarding the trade in this field (Multi-Fibre Arrangement from 1974 to 2000 and Agreement on Textiles and Clothing of the World Trade Organization from 2000 to 2005). After 2005 there was an increased competitive pressure due to the termination of the agreement and liberalization of prices, Romanian market being affected as well.

Traditionally, the world textile and clothing articles market is divided into two main groups of countries the developed ones that have high level technique and have been moving their production toward less developed countries for the mass production when costs have become higher on the one hand, and developing countries that are having the large part of the cotton fibre production and chemical fibre production, and also cheap work force available, on the other hand.

Over time, the textile and clothing articles industry represents an important part of the international trade flows. From this respect, analyzing factors that can influence the export or import flows of different countries in the field of textile and clothing articles industry has been an important topic for many researchers.

So, among the identified variables that can influence exports within textile and clothing articles industry it can be considered: the exchange rate between domestic and foreign currencies, gross domestic product growth rate, foreign direct investment and capital, termination of international agreements in the field (Multi-Fibre Arrangement, WTO's Agreement on Textiles and Clothing), labor costs, raw material cost and quality, technology, tariff and non-tariff barriers [6].

Exchange rate can be negatively associated with the flow of exports [7].
If the level of prices in a national economy is increasing more than the one within other trade partners' economies and the exchange rate is not adjusted to a comparable level, the real exchange rate will decrease. Thus, the price of foreign goods is lower than the price of domestic goods so the later are no more competitive for export.

Some of the trade policies adopted by various countries can also influence textile exports, with reference at the type of the rate - fixed or fluctuant. [8].

Gross domestic product dynamic is giving a clue about the value of goods and services produced within an economy in a particular period of reference. The export supply can be positively related with the growth of the gross domestic product, but in the same time the contribution of the GDP to the increase of the export supply can be reduced [9]. At the same time, the fluctuation of the GDP can be caused with the global recession and for this reason can have a negative impact on exports as well [10]. The rate of foreign direct investments is considered another important variable that can influence the flow of exports in the textile and clothing articles industry because of the insufficient power of the local capital in order to develop the necessary production platforms. In the field of textile and clothing articles the need for constant investment in modern machinery and other edge cutting technologies could be very high [11] knowing that the export of clothing articles has a positive relationship with foreign ownership, transfer of know-how and technologies [12-13].

The termination or modification of international agreements such as Multi-Fibre Arrangement or Agreement on Textiles and Clothing has had a positive impact over textile exports for big producers and countries with resources. For other little capacity companies the protection offered by the agreements was also important. The Multi-Fibre Arrangement was implemented in 1974 as a result of the outstanding growth of textile exports from the developing to developed countries during the period 1962 to 1974. In 1995, a new form of agreement developed by World Trade Organization was taking the place of Multi-Fibre Arrangement. In the period 1995-2005 the agreement was implemented over four different stages regarding the quotas used. After 2005 there has been the full integration into GATT and the elimination of all quotas, the agreement itself being terminated. The termination of the agreement has determined the high rate of growth for India, Pakistan and China in terms of textile exports. Regarding other countries, including Romania too, this was associated with the diminished rate of textile exports, having an important impact over the local production.

In the context of the agreement application, at the level of the European Commission in 2003 a task force has been developed under the name High Level Group on Textiles and Clothing, which highlighted the fact that the continuous process of restructuring and modernization at the level of the industry will lead to the falling of employment in the following years [14-15]. 
Labour cost and other elements regarding labour represent another potential variable influencing the export of textile and clothing articles flows [16]. In the same time labour productivity is considered influential when it comes to export capabilities, firm size and supply capabilities being other important variables to be considered [17-18].

The raw materials costs and the quality or the availability of substitutes can influence either the export of textiles or the import of clothing articles, along other variables such as price of cotton, price of petroleum, market demand etc. can be also important in determining a certain tendency regarding the export flows [19].

Technology itself, besides the foreign capital discussed above represents influential variables, as innovations in the field are representing a factor that can determine the performance of the companies and hence the performance of textile and clothing articles exports [20].

Adoption of innovation, adoption of IT technology can develop the firms' capacity of having more complex design and high quality of products designed for export.

Trade barriers like tariff and non-tariff barriers are of course factors that can affect textile and clothing articles exports. The protectionism that is used by some countries can be a real obstacle in developing the export potential, big producers from the market as China or India having a lot to lose because of the different barriers imposed by other countries such as anti-dumping duty, import quota, green trade barriers etc.

Besides these variables, the complexity of textile and clothing articles market is requesting to take into consideration other possible variables like geographic region, political factors and environmental ones.

In the context of a specific national market, other set of variables that are influencing exports and imports can be highlighted: devaluation of national currency, the growth of foreign exchange reserves, the population growth and the prices index of clothing [21].

Mlachila and Yongzheng led a study in 2004, showing that the Bangladesh garment export performance in the 90's was affected by: low wages, net flows of foreign direct investment and quotas imposed by competing countries [22].

The increase in the production of textiles and clothing articles is generally associated with increased employability and export of textiles and clothing articles is associated with external exchange rates needed to sustain the economic development of the national economy.

Within the article, we are taking into consideration the possibility that the factors that are influencing the imports and exports are different in terms of structure and their importance related to the different countries particularities. Within the process to build any empirical model, one of the main areas of the effort aims identification of appropriate variables to be included in the analysis [23]. Therefore, we want to identify the factors that are affecting the exports and imports of Romanian textile and clothing articles industry.

\section{RESEARCH METHODOLOGY AND RESULTS}

In order to determine different factors identified within the literature review that are influencing the Romanian export and import of textiles and clothing articles, authors have conducted a desk research from public data, using combined statistics and relevant data series available from NIS (National Institute of Statistics), EUROSTAT and national industry bulletins.

Relationship between variables was tested using as a method of analysis the linear regression. The results of the data analysis will allow us to draw certain conclusions about the statistical validation of the tendencies encountered within the data set analyzed.

\section{Analysis of factors that are influencing exports} of textile and clothing articles

Determining the influence of diverse factors on textile and clothing articles export it is necessary to analyze the way in which the Romanian export of textile and clothing articles has evolved taking into account the total of exports and the context of this evolution.

Thus, it will be analyzed the statistical data available referring to the evolution of textile and clothing articles export from Romania to EU, within the context of the total exports to EU. These data series have been chosen because, as it can be seen from the table 1 weight of textile and clothing articles exports of Romania toward EU in the total exports for EU is high, with weights between $50 \%$ and over $90 \%$ for the period under review (1991-2015).

It can be observed that the weight of textile and clothing articles exports in total of the Romanian exports to EU represents about a third until the year 2004 (table 2). Starting with the year 2005, since the World Trade Organization Agreement on Textiles and Clothing was terminated, the competition is getting higher on the EU market. For Romania textiles and clothing articles exports are beginning to drop, trend that it will maintain after 2008 also because of the worldwide economic crisis manifestation. The minimal value will be recorded in 2009, following that beginning with 2010 , the value of Romanian textile and clothing articles exports will recover gradually. So, it becomes very clear the effect of the factor related with international agreements in the field, factor previously highlighted also by the literature review. The important players as China or India have been advantaged by the termination of the agreement. The year 2005 was the one in which the export quota imposed by the agreement have been completely eliminated, fact that has permitted for the big players to expand over the European market through products cheaper than those from different European countries like Romania. Thus, Romanian products were not required at the same level, exports getting lower. 


\begin{tabular}{|l|l|c|c|c|c|c|c|c|c|c|c|c|c|c|}
\hline $\begin{array}{l}\text { Sections and } \\
\text { chapters } \\
\text { according to } \\
\begin{array}{l}\text { Combined } \\
\text { Nomenclature } \\
\text { XI. Textiles and } \\
\text { textile articles }\end{array}\end{array}$ & $\begin{array}{l}\text { Total Romanian } \\
\text { textile and products } \\
\text { from textle exports } \\
\text { worldwide } \\
\text { (thousands of euro) }\end{array}$ & 330421 & 350627 & 669967 & 974435 & 1213887 & 1383441 & 1721640 & 1927676 & 2062437 & 2719193 & 3330094 & 3720463 & 3962842 \\
\hline & $\begin{array}{l}\text { Total Romanian } \\
\text { textile and products } \\
\text { from textile exports } \\
\text { to European Union } \\
\text { (thousands of euro) }\end{array}$ & 165562 & 216358 & 536467 & 825894 & 1033821 & 1218521 & 1522732 & 1737807 & 1886003 & 2463630 & 3031866 & 3395618 & 3609041 \\
\hline & $\begin{array}{l}\text { Weight of export in } \\
\text { EU in comparison } \\
\text { with textile total } \\
\text { exports (\%) }\end{array}$ & $\mathbf{5 0 . 1 1}$ & $\mathbf{6 1 . 7 1}$ & $\mathbf{8 0 . 0 7}$ & $\mathbf{8 4 . 7 6}$ & $\mathbf{8 5 . 1 7}$ & $\mathbf{8 8 . 0 8}$ & $\mathbf{8 8 . 4 5}$ & $\mathbf{9 0 . 1 5}$ & $\mathbf{9 1 . 4 5}$ & $\mathbf{9 0 . 6 0}$ & $\mathbf{9 1 . 0 4}$ & $\mathbf{9 1 . 2 7}$ & $\mathbf{9 1 . 0 7}$ \\
\hline
\end{tabular}

\begin{tabular}{|c|c|c|c|c|c|c|c|c|c|c|c|c|c|}
\hline \multirow{4}{*}{$\begin{array}{l}\text { Sections and } \\
\text { chapters } \\
\text { according to } \\
\text { Combined } \\
\text { Nomenclature } \\
\text { XI. Textiles and } \\
\text { textile articles }\end{array}$} & & 2004 & 2005 & 2006 & 2007 & 2008 & 2009 & 2010 & 2011 & 2012 & 2013 & 2014 & 2015 \\
\hline & $\begin{array}{l}\text { Total Romanian } \\
\text { textile and products } \\
\text { from textile exports } \\
\text { worldwide } \\
\text { (thousands of euro) } \\
\end{array}$ & 4224420 & 4218603 & 4168914 & 3932324 & 3543789 & 2899559 & 3178028 & 3617314 & 3618652 & 3718077 & 3885489 & 3953813 \\
\hline & $\begin{array}{l}\text { Total Romanian } \\
\text { textile and products } \\
\text { from textile exports } \\
\text { to European Union } \\
\text { (thousands of euro) }\end{array}$ & 4014080 & 3993952 & 3935971 & 3713451 & 3321522 & 2724255 & 2951855 & 3349763 & 3342416 & 3419774 & 3564988 & 3614026 \\
\hline & $\begin{array}{l}\text { Weight of export in } \\
\text { EU in comparison } \\
\text { with textile total } \\
\text { exports (\%) }\end{array}$ & 95.02 & 94.67 & 94.41 & 94.43 & 93.73 & 93.95 & 92.88 & 92.60 & 92.37 & 91.98 & 91.75 & 91.41 \\
\hline
\end{tabular}

Source: National Institute of Statistics: TEMPO - time series

Table 2

\begin{tabular}{|l|r|r|r|r|r|r|r|r|r|r|r|r|r|}
\hline year & 1991 & 1992 & 1993 & 1994 & 1995 & 1996 & 1997 & 1998 & 1999 & \multicolumn{1}{c|}{2000} & 2001 & 2002 & 2003 \\
\hline $\begin{array}{l}\text { Total Romanian textile } \\
\text { and products from textile } \\
\text { exports to European Union } \\
\text { (thousands of euro) }\end{array}$ & 165562 & 216358 & 536467 & 825894 & 1033821 & 1218521 & 1522732 & 1737807 & 1886003 & 2463630 & 3031866 & 3395618 & 3609041 \\
\hline $\begin{array}{l}\text { Total export from Romania } \\
\text { in EU (thousands of euro) }\end{array}$ & 1290896 & 1182060 & 1727848 & 2499747 & 3312700 & 3646182 & 4222210 & 4773761 & 5224203 & 7195156 & 8622938 & 9863933 & 10571194 \\
\hline$\%$ & 12.82 & 18.30 & 31.04 & 33.0 & 31.20 & 33.41 & 36.06 & 36.40 & 36.10 & 34.24 & 35.16 & 34.42 & 34.14 \\
\hline
\end{tabular}

Source: National Institute of Statistics: TEMPO - time series

Analyzing the evolution of textile and clothing articles exports and the one of the variable referring to the Gross domestic product (GDP), it can be seen that is a strong relationship between the two variables until the year 2004 (Multiple $R=0.98$, R Square $=0.96$, $F=200.7$, Significance $F=0$ ). After this period the influence is very low (Multiple $R=0.35, R$ Square $=$ $=0.12, F=1.237$, Significance $F=0.295$ ) (analyses realized for the period between 1995-2015, based on data delivered by National Institute of Statistics in case of exports and Eurostat in case of GDP). This can be explained also because of the influence exerted by the termination of the World Trade Organization Agreement on Textiles and Clothing. Analyzing the influence of the variable referring to average wages towards textile and clothing articles exports, it can be seen that this was pretty high until 2004 (Multiple $R=0.96, R$ Square $=0.92, F=48.423$, Significance $F=0$ ) and there is no influence after 2005 (Multiple $R=0.23$, $R$ Square $=0.05, F=0.488$, Significance $F=0.502$ ) (analyses realized for the period between 1999 and 2015, based on data delivered by National Institute of Statistics in case of exports and Eurostat in case of Romanian average wages). Until 2004, the EU was a relatively closed market for the textile industry from outside the Union, so, Romania was having some competitive advantages over the other member countries, especially due to the very little wage. Within the textile industry the work factor is a prime one, the industry being an intensive one as regarding the work without a high degree of qualification. After the year 2005, with the 


\begin{tabular}{|l|r|r|r|r|r|r|r|r|}
\hline year & \multicolumn{1}{|c|}{$\mathbf{2 0 0 0}$} & $\mathbf{2 0 0 1}$ & $\mathbf{2 0 0 2}$ & $\mathbf{2 0 0 3}$ & $\mathbf{2 0 0 4}$ & $\mathbf{2 0 0 5}$ & $\mathbf{2 0 0 6}$ & $\mathbf{2 0 0 7}$ \\
\hline $\begin{array}{l}\text { Net investments, by activity of industry - } \\
\text { Textile products (RON million) }\end{array}$ & 103.1 & 175.9 & 285.9 & 411.7 & 386.2 & 286.8 & 308.6 & 275.1 \\
\hline $\begin{array}{l}\text { Net investments, by activity of industry - } \\
\text { Clothing articles (RON million) }\end{array}$ & 193.9 & 280.5 & 355.6 & 440.2 & 709.4 & 310.9 & 390.9 & 434.7 \\
\hline $\begin{array}{l}\text { Total net investments textile products and } \\
\text { clothing articles (RON million) }\end{array}$ & 297 & 456.4 & 641.5 & 851.9 & 1095.6 & 597.7 & 699.5 & 709.8 \\
\hline $\begin{array}{l}\text { Total net investments textile products and } \\
\text { clothing articles (euro million) }\end{array}$ & 148.8 & 175.4 & 205.2 & 226.8 & 270.3 & 164.9 & 198.5 & 212.7 \\
\hline
\end{tabular}

\begin{tabular}{|l|r|r|r|r|r|r|r|r|}
\hline year & \multicolumn{1}{|c|}{$\mathbf{2 0 0 8}$} & \multicolumn{1}{c|}{$\mathbf{2 0 0 9}$} & $\mathbf{2 0 1 0}$ & $\mathbf{2 0 1 1}$ & $\mathbf{2 0 1 2}$ & $\mathbf{2 0 1 3}$ & $\mathbf{2 0 1 4}$ & $\mathbf{2}$ \\
\hline $\begin{array}{l}\text { Net investments, by activity of industry - } \\
\text { Textile products (RON million) }\end{array}$ & 253.4 & 170.1 & 144.3 & 203 & 160 & 218.6 & 328.3 & \\
\hline $\begin{array}{l}\text { Net investments, by activity of industry - } \\
\text { Clothing articles (RON million) }\end{array}$ & 507.2 & 241.8 & 281.3 & 285.2 & 328.6 & 275 & 432.1 & \\
\hline $\begin{array}{l}\text { Total net investments textile products and } \\
\text { clothing articles (RON million) }\end{array}$ & 760.6 & 411.9 & 425.6 & 488.2 & 488.6 & 493.6 & 760.4 & \\
\hline $\begin{array}{l}\text { Total net investments textile products and } \\
\text { clothing articles (euro million) }\end{array}$ & 206.5 & 97.2 & 101.1 & 115.2 & 109.6 & 111.7 & 171.1 & \\
\hline
\end{tabular}

Source: For Net investments, by activity of industry - Textile products and Clothing articles, in National Institute of Statistics, Romanian Statistical Yearbook, 2006, 2009, 2011, 2015; and in case of foreign exchange rate in National Bank of Romania -

http://www.bnr.ro/Statistics-report-1124.aspx

penetration of the EU market with products from countries like China, Turkey, India, Pakistan, Bangladesh etc., this competitive advantage was lost. Now this advantage exists in the countries with lower wages in which the "lohn production" from Romania is reassigned (ex. Republic of Moldavia).

As regarding the variable referring to the foreign exchange rate, it can be observed that after 2005 again there is no influence upon textile and clothing articles exports (Multiple $\mathrm{R}=0.49$, $\mathrm{R}$ Square $=0.25$, $F=2.957$, Significance $F=0.119$, while the values for the regression until year 2004 are: Multiple $R=$ $=0.99, \mathrm{R}$ Square $=0.97, \mathrm{~F}=98.586$, Significance $\mathrm{F}=0.002$ ) (analyses realized for the period between 2000 and 2015, based on data delivered by National Institute of Statistics in case of exports and National Bank of Romania and National Institute of Statistics in case of foreign exchange rate). This is related with the fact that after 2005 we don't have any competitive advantage.

As regards the net investments at the level of textile and clothing articles industry it can be seen according to table 3 , that these investments have risen until 2004 (1095.6 mil lei in current prices), and after 2005 have dropped very much $(597.7$ mil lei in current prices). Also, it was recorded an important loss in 2009 (411.9 mil lei in current prices) because of the economic crisis.

\section{Analysis of factors that are influencing imports of textile and clothing articles}

As regards the weight of textile and clothing articles imports from EU reported to the weight of worldwide textile and clothing articles, it can be observed that starting from the year 1992 this weight was over $70 \%$ (table 4). After the year 1994 until 2004, the weight will maintain over $80 \%$, while in 2005 and 2006 it drops under $80 \%$ and recovers again after 2006 . For all the considered period of analysis EU stays as the principal partner of Romania for the textile imports.

The analyzed data are showing that there is a pretty strong relationship between Gross Domestic Product and imports of textile and clothing articles. According to the linear regression equation presented below, a quite strong relationship between these two analyzed variables is recorded for the period considered (1995-2015). In case of imports, the data were provided by the National Institute of Statistics, and in case of GDP the data were provided by Eurostat.

The correlation shows that the textile import is a source for the rise of GDP (table 5), because the imported textiles from EU are actually raw material for Romanian companies that are producing under lohn system and are exporting in the EU market the clothing under the brand of the foreign investor. This is happening because within the lohn system process of production, the supply with raw materials is done under the supervision of the foreign company that is authorizing the lohn production especially in case of passive lohn.

The rise of GDP is determining a better buying capacity, at the structural level of textile and clothing products imports, the part of imports that is dealing with clothing is made up by more expensive clothes, well known brands over the European market.

There is also a strong relationship between the variable referring to the average wage in Romania and textile and clothing articles imports (the envisaged period is 1999-2015; for imports the source of data was National Institute of Statistics and in case of 


\begin{tabular}{|c|c|c|c|c|c|c|c|c|c|c|c|c|c|c|}
\hline \multirow{4}{*}{$\begin{array}{l}\text { Sections and } \\
\text { chapters } \\
\text { according to } \\
\text { Combined } \\
\text { Nomenclature } \\
\text { XI. Textiles and } \\
\text { textile articles }\end{array}$} & & 1991 & 1992 & 1993 & 1994 & 1995 & 1996 & 1997 & 1998 & 1999 & 2000 & 2001 & 2002 & 2003 \\
\hline & \begin{tabular}{|l} 
Total Romanian \\
textile and products \\
from textile imports \\
worldwide \\
(thousands of euro)
\end{tabular} & 201147 & 432639 & 562499 & 683171 & 935131 & 1071655 & 1385053 & 1622581 & 1823018 & 2315596 & 2799764 & 3105150 & 3152843 \\
\hline & \begin{tabular}{|l} 
Total Romanian \\
textile and products \\
from textile imports \\
to European Union \\
(thousands of euro)
\end{tabular} & 41407 & 302711 & 432553 & 584127 & 786010 & 923684 & 1195387 & 1403543 & 1569916 & 1951252 & 2352712 & 2550655 & 2583762 \\
\hline & $\begin{array}{l}\text { Weight of import in } \\
\text { EU in comparison } \\
\text { with textile total } \\
\text { exports (\%) }\end{array}$ & 20.6 & 70.0 & 76.9 & 85.5 & 84.1 & 86.2 & 86.3 & 86.5 & 86.1 & 84.3 & 84.0 & 82.1 & 82.0 \\
\hline
\end{tabular}

\begin{tabular}{|c|c|c|c|c|c|c|c|c|c|c|c|c|c|}
\hline \multirow{4}{*}{$\begin{array}{l}\text { Sections and } \\
\text { chapters } \\
\text { according to } \\
\text { Combined } \\
\text { Nomenclature } \\
\text { XI. Textiles and } \\
\text { textile articles }\end{array}$} & & 2004 & 2005 & 2006 & 2007 & 2008 & 2009 & 2010 & 2011 & 2012 & 2013 & 2014 & 2015 \\
\hline & \begin{tabular}{|l} 
Total Romanian \\
textile and products \\
from textile imports \\
worldwide \\
(thousands of euro)
\end{tabular} & 3316396 & 3332199 & |3385104 & 3628531 & 3475556 & 2736646 & 3044052 & 3515035 & 3510886 & 3633262 & 3931501 & 4266055 \\
\hline & $\begin{array}{l}\text { Total Romanian } \\
\text { textile and products } \\
\text { from textile imports } \\
\text { to European Union } \\
\text { (thousands of euro) }\end{array}$ & 2737720 & 2592868 & 2545597 & 3010022 & 2858978 & |2303207 & 2535030 & 2910988 & 2890712 & 2974373 & 3221517 & 3457658 \\
\hline & $\begin{array}{l}\text { Weight of import in } \\
\text { EU in comparison } \\
\text { with textile total } \\
\text { exports (\%) }\end{array}$ & 82.6 & 77.8 & 75.2 & 83.0 & 82.3 & 84.2 & 83.3 & 82.8 & 82.3 & 81.9 & 81.9 & 81.1 \\
\hline
\end{tabular}

Source: National Institute of Statistics: TEMPO - time series

\begin{tabular}{l|r}
\hline \multicolumn{2}{c}{ Regression Statistics } \\
\hline Multiple R & 0.820802 \\
\hline R Square & 0.673716 \\
\hline Adjusted R Square & 0.656543 \\
\hline Observations & 21 \\
\hline
\end{tabular}

ANOVA

\begin{tabular}{l|r|c|c|c|r} 
& \multicolumn{1}{|c|}{$d f$} & \multicolumn{1}{|c|}{ SS } & MS & $F$ & Significance $F$ \\
\cline { 1 - 4 } Regression & 1 & $7.77 \mathrm{E}+12$ & $7.77 \mathrm{E}+12$ & 39.23148 & $5.16 \mathrm{E}-06$ \\
\hline Residual & 19 & $3.76 \mathrm{E}+12$ & $1.98 \mathrm{E}+11$ & \multicolumn{2}{|c}{} \\
\cline { 1 - 3 } Total & 20 & $1.15 \mathrm{E}+13$ & \multicolumn{2}{|l}{} &
\end{tabular}

\begin{tabular}{|l|r|r|r|r|r|r|r|r}
\hline & \multicolumn{3}{c}{ Coefficients } & \multicolumn{1}{c}{ Error } & \multicolumn{1}{c}{ Stat } & \multicolumn{1}{c}{ P-value } & \multicolumn{1}{c}{ Lower 95\% } & \multicolumn{2}{c}{ Upper 95\% } & \multicolumn{1}{c}{ Lower 95.0\% } & Upper 95.0\% \\
\hline Intercept & 1227392 & 203888.5 & 6.019915 & $8.61 \mathrm{E}-06$ & 800648 & 1654135 & 800648 & 1654135 \\
\hline X Variable 1 & 0.012916 & 0.002062 & 6.263504 & $5.16 \mathrm{E}-06$ & 0.0086 & 0.017232 & 0.0086 & 0.017232 \\
\hline
\end{tabular}

Source: analysis of data provided by the National Institute of Statistics and Eurostat

average Romanian wage the data source was Eurostat).

This correlation was tested within the regression equation (table 6) and is accounting the fact that imports are rising in the context in which the wages are bigger. The buying power is rising in the context of the average wage positive evolution, determining more acquisitions and more consumption over time. As majority of clothing imports from European market comprise expensive brands, the monetary value of imports tends to be bigger.

There is a weak relationship between the foreign exchange rate and textile and clothing articles imports (table 7), the considered period is between 2000 and 2015; in case of imports the data source was National Institute of Statistics, in case of foreign exchange rate data were provided by National Bank of Romania and National Institute of Statistics).

The relationship between the two variables is explained by the fact that the low value of the wage is not counterbalanced by the foreign exchange rate in case of exports.

As we stated before, the imported clothes are expensive products that can be assimilated to luxury products class. In the perception of the consumers more expensive clothes are perceived having a better 


\begin{tabular}{l|r}
\hline \multicolumn{2}{c}{ Regression Statistics } \\
\hline Multiple R & 0.822742 \\
\hline R Square & 0.676904 \\
\hline Adjusted R Square & 0.655364 \\
\hline Observations & 17 \\
\hline
\end{tabular}

ANOVA

\begin{tabular}{|c|c|c|c|c|c|}
\hline & $d f$ & SS & $M S$ & $F$ & Significance $F$ \\
\hline Regression & 1 & $2.23 E+12$ & $2.23 \mathrm{E}+12$ & 31.42582 & $5.01 \mathrm{E}-05$ \\
\hline Residual & 15 & $1.07 \mathrm{E}+12$ & $7.1 \mathrm{E}+10$ & & \\
\hline Total & 16 & $3.3 E+12$ & & & \\
\hline
\end{tabular}

\begin{tabular}{|c|c|c|c|c|c|c|c|c|}
\hline & \multicolumn{3}{|c|}{ Standard } & \multirow[b]{2}{*}{$P$-value } & \multirow[b]{2}{*}{ Lower 95\% } & \multirow[b]{2}{*}{ Upper 95\% } & \multirow[b]{2}{*}{ Lower $95.0 \%$} & \multirow[b]{2}{*}{ Upper $95.0 \%$} \\
\hline & Coefficients & Error & $t$ Stat & & & & & \\
\hline Intercept & 1943242 & 141645.1 & 13.71909 & $6.8 \mathrm{E}-10$ & 1641333 & 2245152 & 1641333 & 2245152 \\
\hline $\mathrm{X}$ Variable 1 & 6125.931 & 1092.77 & 5.605873 & 5.01E-05 & 3796.746 & 8455.115 & 3796.746 & 8455.115 \\
\hline
\end{tabular}

Source: analysis of data provided by the National Institute of Statistics and Eurostat

\begin{tabular}{l|r}
\hline \multicolumn{2}{c}{ Regression Statistics } \\
\hline Multiple R & 0.693781 \\
\hline R Square & 0.481333 \\
\hline Adjusted R Square & 0.444285 \\
\hline Observations & 16 \\
\hline
\end{tabular}

ANOVA

\begin{tabular}{|c|c|c|c|c|c|}
\hline & $d f$ & SS & MS & $F$ & Significance $F$ \\
\hline Regression & 1 & $9.9 \mathrm{E}+11$ & $9.9 E+11$ & 12.99226 & 0.002873 \\
\hline Residual & 14 & $1.07 E+12$ & $7.62 E+10$ & & \\
\hline Total & 15 & $2.06 \mathrm{E}+12$ & & & \\
\hline
\end{tabular}

\begin{tabular}{|c|c|c|c|c|c|c|c|c|}
\hline & Coefficients & $\begin{array}{c}\text { Standard } \\
\text { Error }\end{array}$ & $t$ Stat & $P$-value & Lower 95\% & Upper 95\% & Lower $95.0 \%$ & Upper $95.0 \%$ \\
\hline Intercept & 1370484 & 379975.9 & 3.606766 & 0.00286 & 555516.9 & 2185451 & 555516.9 & 2185451 \\
\hline X Variable 1 & 358258.3 & 99392.56 & 3.604477 & 0.002873 & 145082.4 & 571434.1 & 145082.4 & 571434.1 \\
\hline
\end{tabular}

quality and imports related with expensive clothes are influenced by the foreign exchange rate.

\section{CONCLUSIONS}

The results obtained through this research are showing that in the field of textile and clothing articles the flows of export and import are influenced by the following variables: the exchange rate between domestic and foreign currencies, gross domestic product, net investments within the textile and clothing products industry, average wage.

To these variables, we can add the trade agreements that are influencing the dynamic of imports and exports because of the quota used.

From this respect, the evolution of Romanian textile and clothing articles industry was essentially determined by the termination in 2005 of the World Trade Organization Agreement on Textiles and Clothing.
The analysis upon the factors that are affecting the exports of textile and clothing articles is showing interdependence between different phenomena and correlations of variables and this process related with the termination of the agreement. Thus, the correlation between GDP and exports of textile and clothing articles is strong until 2004, becoming very low afterwards. The same is happening with the correlation between average wages and exports of textile and clothing articles, and with the correlation between foreign exchange rate and exports.

In case of net investments, this indicator was growing until 2004 and was getting lower from 2005.

Taking into account these considerations we can conclude that the factors influencing exports of textiles and clothing articles are part of a complex mechanism of inter-related phenomena. 
Because of the complexity of factors that are shaping the evolution of Romanian textile and clothing articles industry and the dynamic of relationships amongst them, the exports and imports flows can be optimized through a series of particular courses of action that exceed the domain of trade policies only: the restoration of local textile production units, reduction of taxation for textile firms, eliminating cumbersome procedures for registration of patents for clothing creations, negotiation of preferential export quotas with the EU, imposition of quotas to protect the Romanian producers for imports from Asia, boosting vocational education in the production of textile and clothing, boosting entrepreneurial initiative in the field of textile and clothing articles industry through training special programs dedicated to young entrepreneurs, boosting the development of joint ventures and transformation of small companies dependent by lohn system in joint ventures partners for foreign investors.

\section{BIBLIOGRAPHY}

[1] Săvoiu G., Siminică M. Disparities, Discrepancies and Specific Concentration - Diversification Trends in the Group of Central and East European Ex-Socialist Countries, In: Amfiteatru Economic, 2016, vol. 18, no. 43, pp. 503-520

[2] Trifan A., Brătucu G., Madar A. Optimization model for an assortment structure of textile confections, In: Industria Textilă, 2015, vol. 66, issue 6, pp. 365-369

[3] Folcuț O. et al. Romanian textiles and clothing industry - present and perspectives, In: Analele Universității "Constantin Brâncuşi" din Târgu Jiu, Secțiunea Economie, 2009, no. 3, pp. 239-256

[4] https://www.wto.org/english/tratop_e/texti_e/texintro_e.htm; https://www.wto.org/english/thewto_e/whatis_e/tif_e/ agrm5_e.htm

[5] National Institute of Statistics, Buletin Statistic de Industrie, 2015, nr. 2, http://www.insse.ro/cms/files/ arhiva_buletine2015/bsi_2.pdf

[6] Yoganandan G., et al. Factors affecting the export performance of textile industry in developing countries-A review of literature, In: International Journal of Commerce, Business and Management, 2013, vol. 2, no. 4, pp. 173-176

[7] Mohamad S., Nair M., Jusoff K. Exchange rates and export competitiveness in selected ASEAN economies, In: International Business Research, 2009, vol. 2, no.2, pp. 156-166

[8] Nonejad M., Mohammadi M. The Effect of exchange rate fluctuation on economic activities of Iran, In: International Review of Management and Business Research, 2016, vol. 5, no. 2, pp. 353-365

[9] Moniruzzaman M.D., Toy M.M., Rashedul H.A.B.M. The export supply model of Bangladesh: an application of cointegration and vector error correction approaches, In: International Journal of Economics and Financial Issues, 2011, vol. 1, no. 4, pp.163-171

[10] Aziz A. RMG trading scenario in India and other major countries-comparative performance \& issues, In: International Journal of Business and Management, 2011, vol. 6, no. 6, pp. 267-275

[11] Sharma M., Prashaant A. An analysis of performance of the Indian Textile Industry in quota free regime, In: Paradigm, 2009, vol. 13, no. 2, pp. 98-109

[12] Wignaraja G. Ownership, technology and buyers: explaining exporting in China and Sri Lanka, In: Transnational Corporations, 2008, vol. 17, no. 2, pp. 1-15

[13] Sharma M., Dhiman R. Determinants affecting Indian Textile Exports: A review. Biz and bytes, In: Journal of Management \& Technology, 2016, vol. 6, no. 2, pp. 193-199

[14] European Commission. Textiles and clothing after 2005 - Recommendations of the High Level Group for textiles and clothing, Commission of the European Communities, Brussels, 2004, pp. 1-10, http://www.europarl.europa.eu/ meetdocs/2004_2009/documents/com/com_com(2004)0668_/com_com(2004)0668_en.pdf.

[15] Schütz M. H., Palan N., Restructuring of the international clothing and textile trade network: the role of Italy and Portugal, In: Journal of Economic Structures, 2016, vol. 5, no. 1, pp. 1-29

[16] Taneja R., Indian textile exports: Past and present, In: International Journal in Multidisciplinary and Academic Research, 2012, vol. 2, no. 2, pp. 1-19

[17] Deshmukh J., Pyne P.K., Labour productivity and export performance: Firm-level evidence from Indian manufacturing industries since 1991, 2013, no. 126, United Nations Economic and Social Commission for Asia and the Pacific (ESCAP), pp. 1-25

[18] Kumar N., Siddharthan N. S. Technology, firm size, and export behavior in developing countries: The case of Indian enterprises, In: Journal of Development Studies, 1994, vol. 31, no. 2, pp. 289-309

[19] Li D.C., Yeh C.W., Li Z.Y. A case study: The prediction of Taiwan's export of polyester fiber using small-data-set learning methods, In: Expert Systems with Applications, 2008, vol. 34, no.3, pp. 1983-1994 
[20] Kongmanila X., Takahashi Y. Innovation, export performance and profitability of Lao garment exporters, In: International Journal of Economics and Management, 2009, vol. 3, no. 2, pp. 225-236

[21] Hermawan I. Analysis of the impact of macroeconomic policies on textile industry and its products in Indonesia, In: Buletin Ekonomi Moneter dan Perbankan, 2011, vol. 13, no. 4, pp. 357-390

[22] Mlachila M., Yang Y. The End of Textiles Quotas: A Case Study of the Impacton Bangladesh No. 4-108, In: International Monetary Fund Working Paper, 2004, pp. 1-37

[23] Škare M., Rabar D. Measuring economic growth using data envelopment analysis, In: Amfiteatru Economic, 2015, vol. 18 , no. 42, pp. 386-406

[24] National Institute of Statistics: TEMPO - time series - http://statistici.insse.ro/shop/?lang=en

[25] European Commission, Eurostat - http://ec.europa.eu/eurostat/search

[26] National Institute of Statistics, Romanian Statistical Yearbook, 2006 - 12.6. Net investments, by activity of industryTextile products and Clothing articles, RON million current prices, p. 445

[27] National Institute of Statistics, Romanian Statistical Yearbook, 2009 - 12.6. Net investments, by activity of industry - Textile products and Clothing articles, RON million current prices, p. 584

[28] National Institute of Statistics, Romanian Statistical Yearbook, $2011-12.6$. Net investments, by activity of industry - Textile products and Clothing articles, RON million current prices, p. 381

[29] National Institute of Statistics, Romanian Statistical Yearbook, $2015-12.4$. Net investments, by activity of industry - Textile products and Clothing articles, RON million current prices, p. 416

[30] National Bank of Romania - Financial markets, Foreign exchange market, Exchange Rate on Forex Market http://www.bnr.ro/Statistics-report-1124.aspx

\section{Authors:}

\section{Prof. PhD. GABRIEL BRĂTUCU ${ }^{1}$ \\ Prof. PhD. GHEORGHE EPURAN ${ }^{1}$ \\ PhD. student ALEXANDRA ZAMFIRACHE ${ }^{1}$ \\ PhD. student MĂDĂLINA-ADINA (STĂNILĂ) OPRIȘ ${ }^{1}$ \\ Lecturer PhD. DANIEL ADRIAN GÂRDAN ${ }^{2}$ \\ Lecturer PhD. IULIANA PETRONELA GÂRDAN² \\ Ec. FLOAREA BUMBAȘ ${ }^{3}$}

${ }^{1}$ University "Transilvania" of Brașov

Faculty of Economic Sciences and Business Administration

Colina Universitatii street, Braşov

e-mail: gabriel.bratucu@unitbv.ro; epuran.gheorghe@unitbv.ro; alexandra.palade@unitbv.ro; madalina.opris@unitbv.ro

2 Spiru Haret University

Faculty of Marketing and International Business

46 G Fabricii Str., District 6, Bucharest

danielgardan@yahoo.com; geangupetronela@yahoo.com

${ }^{3}$ National Research and Development Institute for Textiles and Leather

16 Lucrețiu Pătrăşcanu street, 030508 Bucharest

floribumbas@yahoo.com

Corresponding author:

Prof. PhD. GABRIEL BRĂTUCU

gabriel.bratucu@unitbv.ro 


\section{Comparative analysis of small and medium enterprises organizational performance in clothing industry}

DOI: $10.35530 / I T .068 .02 .1305$

Analiza comparativă a performanţelor organizaţionale ale întreprinderilor mici şi mijlocii din industria de confecţii

Conceptul de capabilitate organizațională a devenit o "modă" a ultimilor ani în literatura de specialitate privitoare la strategia organizațională. La nivel internațional şi cu atât mai puțin național există doar câteva cercetări academice care tratează interdependențele dintre capabilitățile organizaționale și performanța organizațională în întreprinderile mici şi mijlocii din industria confecțiilor. Lucrarea de față iși propune să investigheze legăturile dintre strategia organizațională, capabilitățile întreprinderilor mici şi mijlocii din industria de confecții, mediul real şi perceput al acestora şi performanțele organizaționale din patru țări ale Europei Centrale şi de Est, pe baza utilizării abordărilor metodologice relevante furnizate de Porter, Miles și Snow. Rezultatele confirmă existența unor diferențe și asemănări semnificative la nivelul IMM-urilor analizate din aceste țări în ceea ce privește definirea şi utilizarea instrumentelor specifice managementului strategic.

Cuvinte-cheie: strategie competitivă, capabilități, performanța IMM-urilor, Europa de Sud-Est, antreprenoriat

Comparative analysis of small and medium enterprises organizational performance in clothing industry

The concept of organizational capability has become a "fashionable" one in recent years in scientific literature regarding strategy. Unfortunately, there are only a few academic researches that treat the links between organizational capability and performance in the small and medium companies from clothing industry. This paper aims to investigate by using econometric and statistical specific techniques connections between strategy, capability, organizations internal and external strategic environment and performance of the in SMEs from clothing industry in some countries form South-East Europe by using relevant methodological approaches provided by Miles and Snow and Porter theories. The results confirm the existence of peculiarities between the concepts involved in SMEs from clothing industry in all analysed cultures.

Keywords: competitive strategy, capabilities, SMEs performance, South-East Europe, entrepreneurship

\section{INTRODUCTION}

Recent research regarding strategy emphasizes links between competitive strategies and other organizational and environmental elaborates [1-3]. The most frequently analysed and cited papers on strategy and organizational performance were carried out in developed countries in Western Europe and North America, while comparatively few studies have focused on developing countries such as Romania and other countries in South-East Europe. In addition, most studies have focused on large companies, while little attention has been paid to small and medium companies [4-5].

On the other hand, management research in developing economies such as Romania has expanded in recent year [6-9]. Compared with their EU counterparts, majority of Romanian SMEs are struggling to survive in the complex and unfavourable environment. An estimated two-thirds of the Romanian new 140,000 SMEs don't survive in the first year since establishment [10].

This article investigate the literature correlations between organizational capabilities, SME environment (internal and external) and organizational performance in countries from South-East Europe. While the economies of these countries are at different stages of development, the comparison is important for academics and entrepreneurs from these countries for several reasons. First, entrepreneurs can easily understand and interpret ongoing weaknesses, strengths, challenges and opportunities of their companies and management by reviewing the national and regional comparisons. Secondly, academics can better understand both the benefits and the obstacles associated with the application of strategy models in countries from this part of Europe.

\section{LITERATURE REVIEW}

The concept of organizational strategy is connected within the evolution of strategic management as a scientific discipline. During the crystallization of the concept of strategy, experts have various typologies, "some distinctive and others based on prior developed frameworks" [11]. Of the various strategic typologies that have been proposed during the last decades, those of Porter [12] and Miles and Snow 
[13] have received the most academic attention [14]. Event today, both Porter's and Miles and Snow's original typologies remain amidst the most widely cited, tested, and refined [15]. Porter underline that organizations must develop either cost or differentiation strategies, making no distinction regarding strategy focus. According to him, businesses that endeavour to combine differentiation and cost typically become "stuck in the middle" an idea that received considerable advocacy [11, 16-17]. Recent studies questioned Porter's controversy and suggested that businesses adopting combination approaches might outperform business with single strategy orientation [4, 18-19].

The notion of capabilities emphasizes the uniqueness of each organization. To be fully used, resources must be "coupled with complex skills, capabilities and knowledge that enable organizations to coordinate activities" [20]. On the other hand, a number of studies have suggested links between organizational capabilities and strategies [21-25]. Entrepreneurs are charged with the tasks of collecting and linking capabilities to material, human, financial and informational resources and adapting to the changing environment [26]. The literature review supports a connection between capabilities and performance [27-29]. Bowman and Gatignon emphasize the direct impact of technical and marketing capabilities on initial advocates' of change and performance [30]. lansiti and Clark [31] found that "knowledge integration capability in product development correlated positively with firm performance and its improvements over time". The amplification of various organizational capabilities is also believed to have a strong assertive influence on business performance $[24,32]$.

Thompson viewed managing SMEs environment as one of top management's primary challenge [33]. SME environment "influences strategies, which in turn influence performance" [34]. Therefore, in some respects, a firm's success is a function of its environment [35]. Environmental complexity and dynamism can limit company "ability to assess the environment at any given time" [36]. Even today, it remains a decisive issue in SME strategy research because it forms a basic part of the interpretive thinking regarding formulation, implementation and evaluation of strategy [13, 37-38]. Consequently, we consider that organizations design their strategies and attempt to shape the competitive environment as one means of addressing IEE [39].

\section{METHODS}

In order to achieve our research objectives, we develop a series of hypothesis presented below.

The first assumption considers the connection between strategy and performance among SMEs from clothing industry, and is important as a basis for the remaining assumptions:

\section{A. Entrepreneurs in reactor SMEs will report less} satisfaction with performance.
The second assumption was based on Porter [40] approach who suggested that successful businesses follow either cost or differentiation, but not simultaneously. In addition, Miles and Snow [41] suggested that firms adopting a focus strategy typically outperform those without one. A similar finding is anticipated herein:

\section{B. Businesses with moderate strategic focus will perform poorly.}

The third set of assumptions emphasizes the connection between capabilities and business performance. Research examining the direct connection between capability development and performance has risen in recent decades [42]. Therefore:

C.1. Capabilities regarding marketing and business performance it is positive.

C.2. Market linking capabilities and business performance it is positive.

C.3. Capabilities regarding technology and business performance it is positive.

C.4. Capabilities regarding management and business performance it is positive.

The fourth set of assumptions emphasizes the relationship between IEE and business performance. IEE influences strategy formulation, which in turn influences business performance [34]. Therefore:

$D 1$. IEE and business performance it is negative.

D2. IEE about technology and business performance it is negative.

D3. IEE and business performance it is negative.

The fifth set of hypotheses concerns strategic capabilities with regard to marketing, market linking, technology and management. Businesses pursuing a single, focused strategy will be more focussed in their pursuit of high performance and will tend to outperform reactors:

E1. "Defenders" in analysed SMEs will report the highest degree of market linking capabilities.

E2. "Prospectors" in analysed SMEs will report the highest degree of technology capabilities.

E3. "Analysers" in analysed SMEs will report the highest degree of marketing capabilities.

E.4. "Reactors" in analysed SMEs will report the lowest degree of management capabilities.

The final set of assumptions concerns the relationship between IEE and strategy. We intend to identify relationships between:

F1. "Defenders" in analysed SMEs will report the lowest degree of competitive IEE.

F2. "Prospectors" in analysed SMEs will report the lowest degree of technology IEE.

F3. "Analysers" in analysed SMEs will report the lowest degree of market IEE.

Businesses were categorized in the Miles and Snow typology amended by Zajac and Shortell's [43] and James and Hatten [44] scale.

In order to verify the hypotheses research, we identified a representative sample of entrepreneurs from small and medium enterprises (fewer than 250 employees) from clothing industry from the surveyed four countries (table 1). 


\begin{tabular}{|c|c|c|c|c|}
\hline Variable & South-Ea & ries $(n=171)$ & \multicolumn{2}{|c|}{ Romania $(n=170)$} \\
\hline \multicolumn{5}{|c|}{ Management level } \\
\hline Lower management & 22 & $12.87 \%$ & 29 & $17 \%$ \\
\hline Middle management & 61 & $35.67 \%$ & 65 & $38 \%$ \\
\hline Top management & 88 & $51.46 \%$ & 76 & $45 \%$ \\
\hline \multicolumn{5}{|c|}{ Background } \\
\hline Accounting/finance & 28 & $16.37 \%$ & 22 & $12.94 \%$ \\
\hline Management/HR & 31 & $18.13 \%$ & 28 & $16.47 \%$ \\
\hline Marketing/sales & 48 & $28.07 \%$ & 42 & $24.71 \%$ \\
\hline Production/engineering & 64 & $37.43 \%$ & 78 & $45.88 \%$ \\
\hline \multicolumn{5}{|c|}{ Gender } \\
\hline Male & 73 & $42.69 \%$ & 69 & $40.59 \%$ \\
\hline Female & 98 & $57.31 \%$ & 101 & $59.41 \%$ \\
\hline \multicolumn{5}{|c|}{ Firm size } \\
\hline Micro and small (1-49) & 112 & $65.50 \%$ & 121 & $71.18 \%$ \\
\hline Medium (50-249) & 59 & $34.50 \%$ & 49 & $28.82 \%$ \\
\hline
\end{tabular}

Source: own research

Reliability was rated for the performance, capability and enterprise environment scales. We found out that factor loadings and coefficient a's were supportive (table 2). Factor scores were utilized as surrogates for each construct (tables 3 and 4 ). In order to reduce method bias we use Harmon's single factor test to employ test for potential influence.

\section{FINDINGS}

Next, we will briefly present the main findings identified as a result of processing and interpretation of data from questionnaires.

- F1 was supported in other S-E European countries but was not supported in Romania.

- F2 was not supported in the S-E European but was supported in Romania.

- F3 was not supported in either nation from S-E Europe.

- First assumption was substantiated in all national involved. Issues regarding performance were significantly lower in "Reactors" than in "Defenders", "Prospectors" and "Analysers".

Table 2

\begin{tabular}{|l|c|c|}
\hline \multicolumn{1}{|c|}{ Item } & $\begin{array}{c}\text { South-East Europe } \\
\text { countries }(\alpha=\mathbf{0 . 9 5})\end{array}$ & $\begin{array}{c}\text { Romania } \\
(\boldsymbol{\alpha = 0 . 8 6 1 )}\end{array}$ \\
\hline 1. Sales growth & 0.692 & 0.690 \\
\hline 2. Profit growth & 0.570 & 0.745 \\
\hline 3. Market share & 0.812 & 0.714 \\
\hline 4. Return on assets & 0.875 & 0.655 \\
\hline 5. Return on equity & 0.804 & 0.769 \\
\hline 6. Return on sales & 0.855 & 0.667 \\
\hline 7. Overall & 0.871 & 0.711 \\
\hline 8. Composite & 0.868 & 0.751 \\
\hline
\end{tabular}

Source: own research

industroia textillă
Table 3

\begin{tabular}{|c|c|c|}
\hline Item & $\begin{array}{c}\text { South-East } \\
\text { Europe } \\
\text { countries }\end{array}$ & Romania \\
\hline Marketing capabilities & $(\alpha=0.938)$ & $(\alpha=0.762)$ \\
\hline 1. Customers knowledge & 0.781 & 0.697 \\
\hline 2. Competitors knowledge & 0.786 & 0.641 \\
\hline 3. Marketing activities integration & 0.705 & 0.785 \\
\hline $\begin{array}{l}\text { 4. Skill to segment and target } \\
\text { markets }\end{array}$ & 0.788 & 0.616 \\
\hline $\begin{array}{l}\text { 5. Effectiveness of pricing } \\
\text { programs }\end{array}$ & 0.769 & 0.611 \\
\hline $\begin{array}{l}\text { 6. Effectiveness of advertising } \\
\text { programs }\end{array}$ & 0.777 & 0.702 \\
\hline Market linking capabilities & $(\alpha=0.880)$ & $(\alpha=0.821)$ \\
\hline 1. Market sensing & 0.761 & 0.658 \\
\hline 2. Customer linking & 0.840 & 0.777 \\
\hline $\begin{array}{l}\text { 3. Creating durable supplier } \\
\text { relationships }\end{array}$ & 0.735 & 0.724 \\
\hline 4. Ability to retain customers & 0.800 & 0.789 \\
\hline 5. Channel-bonding & 0.749 & 0.776 \\
\hline $\begin{array}{l}\text { 6. Relationships with channel } \\
\text { members }\end{array}$ & 0.854 & 0.655 \\
\hline Technology capabilities & $(\alpha=0.925)$ & $(\alpha=0.811)$ \\
\hline 1. New product development & 0.891 & 0.747 \\
\hline 2. Manufacturing processes & 0.830 & 0.767 \\
\hline 3. Technology development & 0.862 & 0.779 \\
\hline $\begin{array}{l}\text { 4. Predicting technological } \\
\text { change }\end{array}$ & 0.840 & 0.571 \\
\hline 5. Production facilities & 0.833 & 0.789 \\
\hline 6. Quality control systems & 0.882 & 0.671 \\
\hline Management capabilities & $(\alpha=0.882)$ & $(\alpha=0.821)$ \\
\hline 1. Integrated logistics systems & 0.768 & 0.720 \\
\hline 2. Cost control capabilities & 0.792 & 0.769 \\
\hline 3. Financial management skills & 0.840 & 0.691 \\
\hline 4. Human resource management & 0.835 & 0.800 \\
\hline $\begin{array}{l}\text { 5. Profitability and revenue } \\
\text { forecasting }\end{array}$ & 0.834 & 0.754 \\
\hline 6. Marketing planning process & 0.699 & 0.624 \\
\hline
\end{tabular}




\begin{tabular}{|c|c|c|}
\hline Item & $\begin{array}{c}\text { South-East } \\
\text { Europe } \\
\text { countries }\end{array}$ & Romania \\
\hline IEE regarding markets & $(\alpha=0.821)$ & $(\alpha=0.829)$ \\
\hline $\begin{array}{l}\text { 1. Changes in customers' } \\
\text { product preferences }\end{array}$ & 0.745 & 0.711 \\
\hline $\begin{array}{l}\text { 2. Customers look for new } \\
\text { products }\end{array}$ & 0.827 & 0.685 \\
\hline 3. Sensitivity to price & 0.794 & 0.852 \\
\hline $\begin{array}{l}\text { 4. New customers different } \\
\text { from existing ones }\end{array}$ & 0.609 & 0.704 \\
\hline 5. Cater to same customers & 0.626 & 0.771 \\
\hline $\begin{array}{l}\text { 6. Difficult to predict } \\
\text { marketplace changes }\end{array}$ & 0.751 & 0.672 \\
\hline IEE regarding technology & $(\alpha=0.944)$ & $(\alpha=0.852)$ \\
\hline $\begin{array}{l}\text { 1. Rapidly changing } \\
\text { technology }\end{array}$ & 0.882 & 0.796 \\
\hline $\begin{array}{l}\text { 2. Technological changes } \\
\text { create big opportunities } \\
\end{array}$ & 0.891 & 0.782 \\
\hline $\begin{array}{l}\text { 3. Difficult to forecast } \\
\text { technology }\end{array}$ & 0.880 & 0.731 \\
\hline $\begin{array}{l}\text { 4. Technology creates new } \\
\text { products }\end{array}$ & 0.912 & 0.752 \\
\hline $\begin{array}{l}\text { 5. Technological changes are } \\
\text { minor (recoded) }\end{array}$ & 0.876 & 0.745 \\
\hline $\begin{array}{l}\text { 6. Technological changes are } \\
\text { frequent }\end{array}$ & 0.876 & 0.760 \\
\hline IEE regarding competitors & $(\alpha=0.825)$ & $(\alpha=0.774)$ \\
\hline 1. Competition is cutthroat & 0.741 & 0.672 \\
\hline $\begin{array}{l}\text { 2. Many promotion wars in the } \\
\text { industry }\end{array}$ & 0.734 & 0.743 \\
\hline $\begin{array}{l}\text { 3. One competitor can readily } \\
\text { match another }\end{array}$ & 0.719 & 0.575 \\
\hline $\begin{array}{l}\text { 4. Price competition is a } \\
\text { hallmark }\end{array}$ & 0.797 & 0.761 \\
\hline $\begin{array}{l}\text { 5. Competitive moves } \\
\text { are frequent }\end{array}$ & 0.729 & 0.586 \\
\hline $\begin{array}{l}\text { 6. Competitors are relatively } \\
\text { weak }\end{array}$ & 0.670 & 0.748 \\
\hline
\end{tabular}

\begin{tabular}{|l|c|c|}
\hline \multicolumn{1}{|c|}{ Item } & $\begin{array}{c}\text { South-East } \\
\text { Europe } \\
\text { countries }\end{array}$ & Romania \\
\hline Capabilities on marketing & $0.271^{*}$ & $0.327^{*}$ \\
\hline Capabilities on market linking & $0.197^{*}$ & $0.422^{*}$ \\
\hline Capabilities on technology & $0.348^{*}$ & $0.251^{*}$ \\
\hline Capabilities on management & $0.341^{*}$ & $0.582^{*}$ \\
\hline IEE on marketing & 0.120 & $0.176^{*}$ \\
\hline IEE on technology & 0.083 & 0.112 \\
\hline IEE on competitors & 0.100 & -0.038 \\
\hline
\end{tabular}

Note: *Significant at 0.05 levels

Source: own research

Table 7

\begin{tabular}{|c|c|c|}
\hline Item & $\begin{array}{l}\text { South-East } \\
\text { Europe } \\
\text { countries }\end{array}$ & Romania \\
\hline \multicolumn{3}{|l|}{ Marketing capabilities } \\
\hline "Defender " & -0.199 & -0.144 \\
\hline "Prospector" & 0.037 & 0.191 \\
\hline "Analyser" & 0.132 & 0.196 \\
\hline "Reactor" & 0.000 & -0.448 \\
\hline F-value (significance) & $0.791(0.492)$ & $3.247(0.019)$ \\
\hline \multicolumn{3}{|c|}{ Market linking capabilities } \\
\hline "Defender “ & -0.093 & 0.315 \\
\hline "Prospector" & 0.267 & -0.144 \\
\hline "Analyser" & -0.120 & -0.021 \\
\hline "Reactor" & -0.279 & -0.640 \\
\hline F-value (significance) & $2.638(0.047)$ & $5.684(0.001)$ \\
\hline \multicolumn{3}{|c|}{ Technology capabilities } \\
\hline "Defender " & -0.187 & 0.198 \\
\hline "Prospector" & 0.129 & 0.314 \\
\hline "Analyser" & -0.075 & -0.152 \\
\hline "Reactor" & 0.087 & -0.607 \\
\hline F-value (significance) & $1.021(0.375)$ & $5.389(0.001)$ \\
\hline \multicolumn{3}{|c|}{ Management capabilities } \\
\hline "Defender “ & 0.172 & 0.301 \\
\hline "Prospector" & 0.237 & -0.121 \\
\hline "Analyser" & -0.529 & 0.011 \\
\hline "Reactor" & -0.161 & -0.772 \\
\hline F-value (significance) & $4.929(0.002)$ & $7.044(0.000)$ \\
\hline
\end{tabular}

Source: own research

- The second assumption was demonstrated. Entrepreneurs from businesses with moderate strategic orientation reported lower levels of performance than did businesses with a single focused strategy (table 5). Firm size did not appear to play a role in generating performance.

- C1-C4 assumptions were substantiated for all countries (table 6). Either of the capability factor scores was firmly associated with performance.

Source: own research 


\begin{tabular}{|c|c|c|}
\hline Item & $\begin{array}{l}\text { South-East } \\
\text { Europe } \\
\text { countries }\end{array}$ & Romania \\
\hline \multicolumn{3}{|l|}{ IEE regarding markets } \\
\hline "Defender " & 0.076 & 0.168 \\
\hline "Prospector" & 0.042 & -0.591 \\
\hline "Analyser" & -0.209 & 0.071 \\
\hline "Reactor" & 0.075 & 0.147 \\
\hline F-value (significance) & $0.769(0.500)$ & $4.537(0.002)$ \\
\hline \multicolumn{3}{|c|}{ IEE regarding technology } \\
\hline "Defender “ & -0.291 & 0.021 \\
\hline "Prospector" & 0.074 & -0.542 \\
\hline "Analyser" & 0.044 & 0.037 \\
\hline "Reactor" & 0.153 & 0.601 \\
\hline F-value (significance) & $1.511(0.209)$ & $6.255(0.000)$ \\
\hline \multicolumn{3}{|c|}{ IEE regarding competitors } \\
\hline "Defender “ & -0.411 & -0.162 \\
\hline "Prospector" & 0.277 & 0.101 \\
\hline "Analyser" & -0.232 & 0.008 \\
\hline "Reactor" & 0.281 & 0.291 \\
\hline F-value (significance) & $5.772(0.001)$ & $1.307(0.269)$ \\
\hline
\end{tabular}

environment (IEE) and capabilities remain elusive. We found out that business strategy selected by an organization could influence the IEE perceived by its entrepreneurs for two reasons. First, entrepreneurs in businesses employing strategy might tend to perceive particularly IEE in a given domain. We refer to this notion as entrepreneurial real and perceived environment [45]. On the other hand, if a strategy is designed in a manner that minimizes the external environment risks, it could imply that organization might not allocate sufficient resources (material, financial, human or informational) to reduce other type of risks in the future. From this point of view, the business strategy is selected as a means of managing the firm risks.

The findings generate a number of implications.

First, capability regarding development can help SMEs address some of the challenges associated with enterprise environment (IEE). The different economies of Romania, Bulgaria, Serbia and Republic of Moldova present contrasting pictures of IEE that occurs during the time as an economy develops. The challenges differ across nations, but Romanian SMEs can benefit from comprehension of how these firms are coping with a quite different competitive environment.

We found out that Romanian SMEs from clothing industry prefer cost-based approaches because the growth of the national economy has been progressing for a moderate period of time, and most entrepreneurs are trying to obtain middle-class revenue. A differentiated approach of the market is difficult to generate in most Romanian economy sectors due to the low level of wages for most of the jobs and specific consumer behaviour of the population.

We identified opportunities for future research. First, this study could be multiplied in Central Europe countries (Visegrad Group), which in terms of cultural and entrepreneurial behaviour match with our sample. However, without additional research, the generalizability of the findings remains subtle. Second, we must acknowledge the difficulties generated by constructs and surveys which are employed in different cultures [46]. The results incline to be less reliable were we identified strong barriers in education, economy, culture or language [47]. We consider that it is important to maintain methodological consistency in cross-national researches, although some economic and managerial notions and constructs - i.e. capabilities and performance - may be interpreted differently for every country.

\section{BIBLIOGRAPHY}

[1] Barth, H., (2003), Fit among competitive strategy, administrative mechanisms, and performance: a comparative study of small firms in mature and new industries, In: Journal of Small Business Management, vol. 41, pp. 133-147

[2] Capps, C.J. III, Jackson, G.K. and Hazen, S.E., (2002), Strategic management synergy in the 21st century, In: Journal of Applied Management and Entrepreneurship, vol. 7, no. 1, pp. 76-93 
[3] Leask, G. and Parker, D., (2007), Strategic groups, competitive groups and performance within the U.K. pharmaceutical industry: improving our understanding of the competitive process, In: Strategic Management Journal, vol. 28, pp. 723-745

[4] Ghobadian, A. and O'Regan, N., (2006), The impact of ownership on small firm behaviour and performance, In: International Small Business Journal, vol. 24, no. 6, pp. 555-586

[5] Hoque, Z., (2004), A contingency model of the association between strategy, environmental uncertainty and performance measurement: impact on organizational performance, In: International Business Review, vol. 13, pp. 485-502

[6] Ceptureanu E.G., Ceptureanu S.I., (2014), Change management survey on innovative ITC Romanian SMEs, In: Quality - Access to success, vol. 16, no. 144, pp. 62-65

[7] Jusoh, R. and Parnell, J.A., (2008), Competitive strategy and performance measurement in the Malaysian context: an exploratory study, In: Management Decision, vol. 46, pp. 5-31.

[8] Tracey, P. and Phillips, N., (2011), Entrepreneurship in emerging markets: strategies for new venture creation in uncertain institutional contexts, In: Management International Review, vol. 51, pp. 23-39.

[9] Ceptureanu S.I., (2015), Competitiveness of SMEs, In: Business Excellence and Management Review, vol. 5, no. 2, pp. 55-67

[10] http://www.capital.ro/un-imm-din-trei-moare-in-primul-an-de-la-infiintare-183199.html (Accessed on 24 February 2016)

[11] Garrigos-Simon, F.J., Marques, D.P. and Narangajavana, Y., (2005), Competitive strategies and performance in Spanish hospitality firms, In: International Journal of Contemporary Hospitality Management, vol. 17, no. 1, pp. 22-38

[12] Porter, M.E., (1980), Competitive Strategy, Free Press, New York, NY

[13] Miles, R.E. and Snow, C.C., (1986), Organizations: new concepts for new forms, In: California Management Review, vol. 18, no. 3, pp. 62-73

[14] Veett, N.M.K., Ghobadian, A. and Gallear, D., (2009), Business-level strategy and performance - evidence from manufacturing firms, paper presented at the Annual Meeting of the Academy of Management, Chicago, IL

[15] Bowman, C., (2008), Generic strategies: a substitute for thinking? In: Ashridge Journal, vol. 5, pp. 6-11

[16] Dess, G.G. and Davis, P.S., (1984), Porter's generic strategies as determinants of strategic group membership and performance, In: Academy of Management Journal, vol. 26, pp. 467-488

[17] Hawes, J.M. and Crittendon, W.F., (1984), A taxonomy of competitive retailing strategies, In: Strategic Management Journal, vol. 5, no. 2, pp. 275-287

[18] Murray, A.I., (1988), A contingency view of Porter's 'generic strategies, Academy of Management, In: Management Review, vol. 13, no. 3, pp. 390-400

[19] Wright, P., (1987), Arefinement of Porter's strategies, In: Strategic Management Journal, vol. 8, pp. 93-101

[20] Teece, D., Pisano, G. and Shuen, A., (1990), Firm capabilities, resources and the concept of corporate strategy, In: Consortium on Competitiveness and Cooperation W.P. No. 90-9, Centre for Research in Management, University of California at Berkeley, Berkeley, CA

[21] Bowman, C. and Ambrosini, V., (2003), How the resource-based view and the dynamic capability views of the firm inform corporate-level strategy, In: British Journal of Management, vol.14, pp. 289-303

[22] Campbell-Hunt, C., (2000), What have we learned about generic strategies? A meta-analysis, In: Strategic Management Journal, vol. 21, pp. 127-154

[23] Hussey, D., (2002), Company analysis: determining strategic capability, In: Strategic Change, vol. 11, pp. 43-52.

[24] Pandza, K. and Thorpe, R., (2009), Creative search and strategic sense-making: missing dimensions in the concept of dynamic capabilities, In: British Journal of Management, vol. 20, pp. 118-131

[25] Ceptureanu E.G., (2015), Research regarding change management tools on EU SMEs, In: Business Excellence and Management Review, vol. 5, no. 2, pp. 28-32

[26] Pang, P., (2008), Translated from 'SCMM maturity model of strategic capability of SMEs, In: Probe, vol. 9, pp. 29-30

[27] Mitchell, W., (1991), Dual clocks: entry order influences on incumbent and newcomer market share and survival when specialized assets retain their value, In: Strategic Management Journal, vol. 12, pp. 85-100

[28] Shamsie, J., Phelps, C. and Kuperman, J., (2004), Better late than never: study of late entrants in household electrical equipment, In: Strategic Management Journal, vol. 25, pp. 69-84

[29] Boulding, W. and Christen, M., (2001), Sustainable pioneering advantage: profit implications of market entry order, In: Marketing Science, vol. 22, no. 3, pp. 371-92

[30] Bowman, D. and Gatignon, H., (1995), Determinants of competitor response time to a new product introduction, In: Journal of Marketing Research, vol. 23, pp. 42-53

[31] Iansiti, M. and Clark, K.B., (1994), Integration and dynamic capability: evidence from product development in automobiles and mainframe computers, In: Industrial and Corporate Change, vol. 3, pp. 557-605 
[32] DeSarbo, W.S., Di Benedetto, C.A., Song, M. and Sinha, I., (2005), Revisiting the miles and snow strategic framework: uncovering interrelationships between strategic types, capabilities, environmental uncertainty, and firm performance, In: Strategic Management Journal, vol. 26, pp. 47-74

[33] Thompson, J., (1967), Organizations in Action, McGraw-Hill, New York, NY

[34] Swamidass, P.M. and Newell, W.T., (1987), Manufacturing strategy, environmental uncertainty and performance: a path analytic model, In: Management Science, vol. 33, pp. 509-524

[35] Ceptureanu S.I., (2015), Knowledge management in Romanian young SMEs, In: Review of International Comparative Management, vol. 16, no.1, pp. 5-22

[36] Beal, R.M., (2000), Competing effectively: environmental scanning, competitive strategy, and organizational performance in small manufacturing firms, In: Journal of Small Business Management, vol. 38, pp. 27-47

[37] Chong, V.K. and Chong, K.M., (1997), Strategic choices, environmental uncertainty and SBU performance: a note on the intervening role of management accounting systems, In: Accounting \& Business Research, vol. 27, pp. 268-276

[38] Clemens, B., Bamford, C.E. and Douglas, T.J., (2008), Choosing strategic responses to address emerging environmental regulations: size, perceived influence and uncertainty, In: Business Strategy and the Environment, vol. 17, pp. 493-511

[39] Sun, L., (2011), Translated from 'research on band marketing strategy of SMEs, In: Economic Research Guide, vol. 27, pp. 204-207

[40] Porter, M.E., (1981), The contributions of industrial organization to strategic management, In: Academy of Management Review, vol. 6, pp. 609-620

[41] Miles, R.E. and Snow, C.C., (1978), "Organizational Strategy, Structure, and Process”, West, New York, NY

[42] Morgan, N.A., Vorhies, D.W. and Mason, C.H., (2009), Market orientation, marketing capabilities, and firm performance, In: Strategic Management Journal, vol. 30, pp. 909-920

[43] Zajac, E., Shortell, S.M., (1989), Changing generic strategies: likelihood, direction, and performance implications, In: Strategic Management Journal, vol. 10, no. 5, pp. 413-430

[44] James, W.L. and Hatten, K.J., (1995), Further evidence on the validity of the self-typing paragraph approach: miles and snow strategic archetypes in banking, In: Strategic Management Journal, vol. 16, pp. 161-168

[45] Ceptureanu S.I., Ceptureanu E.G., (2015), Knowledge management in Romanian companies, In: Quality - Access to success, vol. 16 , no. 145 , pp. $61-66$

[46] Punnett, B.J. and Shenkar, O., (1994), International management research: toward a contingency approach, In: Advances in International Comparative Management, vol. 9, pp. 39-55

[47] Hofstede, G., (2001), Culture Consequences: comparing values, behaviours, institutions, and organizations across nations ( $2^{\text {nd }}$ edition), Thousand Oaks

\section{Authors:}

\section{CEPTUREANU SEBASTIAN ION ${ }^{1}$ CEPTUREANU EDUARD GABRIEL ${ }^{1}$ VISILEANU EMILIA ${ }^{2}$}

${ }^{1}$ Bucharest University of Economic Studies, Faculty of Management sebastian.ceptureanu@man.ase.ro; eduard.ceptureanu@man.ase.ro

${ }^{2}$ The National Research and Development Institute for Textiles and Leather visilean@ns.certex.ro

\section{Corresponding author:}

Ceptureanu Sebastian Ion sebastian.ceptureanu@man.ase.ro 


\section{Erratum}

In issue nr. 1/2017, in the article Design of an electronically equipped sailing garment for improved safety the right address of the author YAVUZ SENOL is:

Dokuz Eylul University, Faculty of Engineering, Department of Electrical and Electronics Engineering,

Tınaztepe Campus, 35397, Buca, Izmir, Turkey. 